GEOHYDROLOGY OF INDIAN RIVER COUNTY, FLORIDA

By G.R. Schiner and C.P. Laughlin, U.S. Geological Survey and D.J. Toth, St. Johns River Water Management District

U.S. GEOLOGICAL SURVEY

Water-Resources Investigations Report 88-4073

Prepared in cooperation with the

INDIAN RIVER COUNTY BOARD OF COMMISSIONERS and the ST. JOHNS RIVER WATER MANAGEMENT DISTRICT

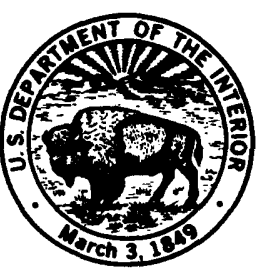

Tallahassee, Florida

1988 
DEPARTMENT OF THE INTERIOR

DONALD PAUL HODEL, Secretary

U.S. GEOLOGICAL SURVEY

Dallas L. Peck, Director

For additional information write to:

District Chief

U.S. Geological Survey Suite 3015 227 North Bronough Street Tallahassee, Florida 32301
Copies of this report can be purchased from:

U.S. Geological Survey

Books and Open-File Reports Section

Federal Center, Building 810

Box 25425

Denver, Colorado 80225 


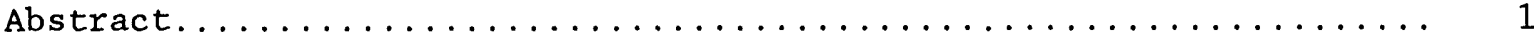

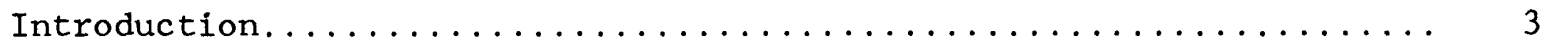

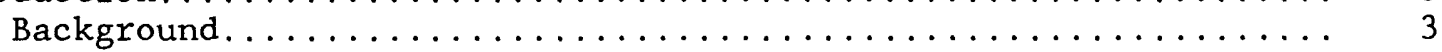

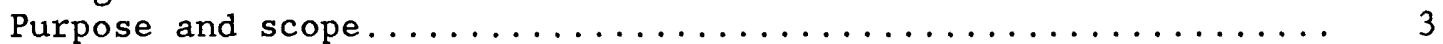

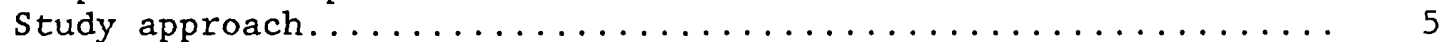

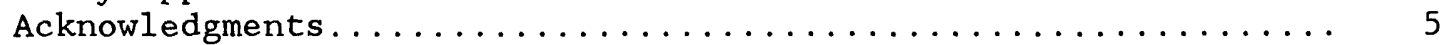

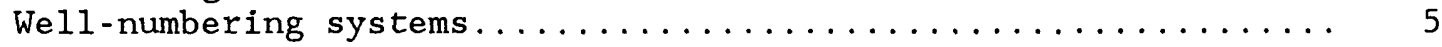

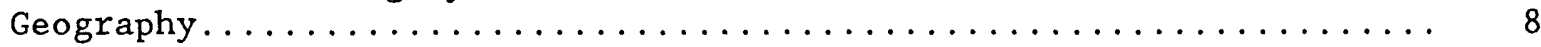

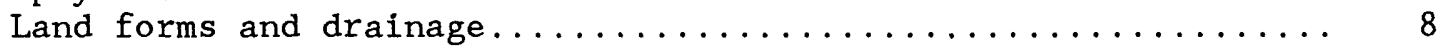

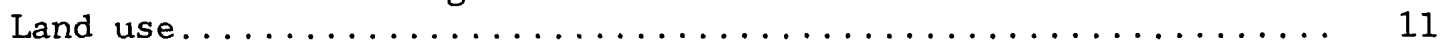

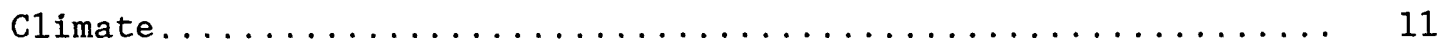

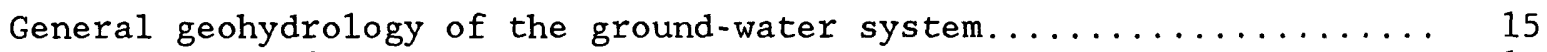

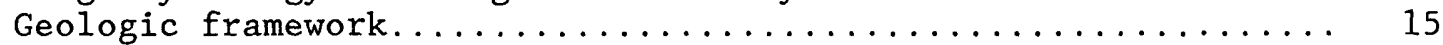

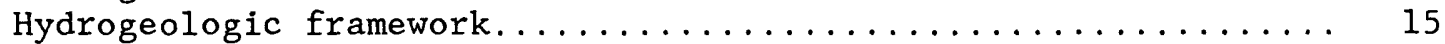

Ground-water occurrence and movement.................. 20

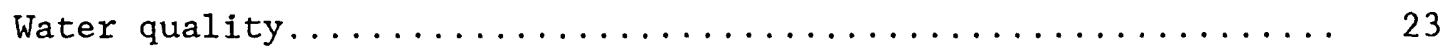

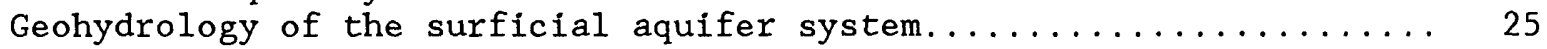

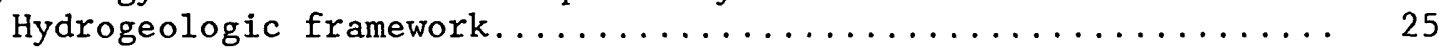

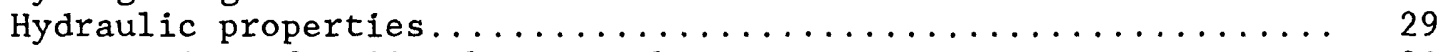

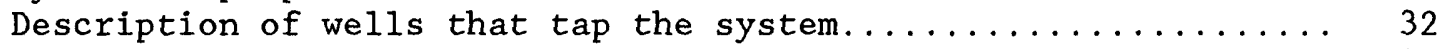

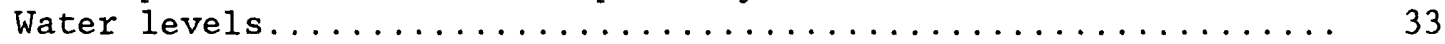

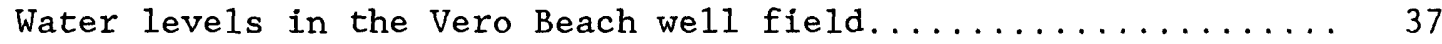

Recharge and discharge in the system..................41

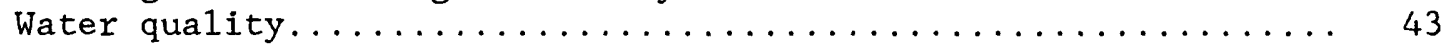

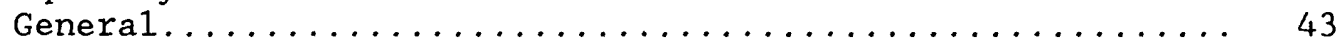

Occurrence of chlorides....................... 45

Occurrence of chlorides in the Vero Beach area........ 51

Potential development.......................... 56

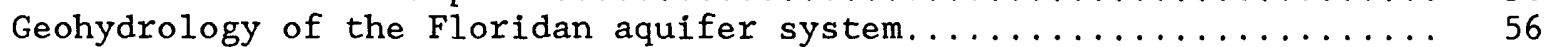

Description of the hydrologic units.................. 56

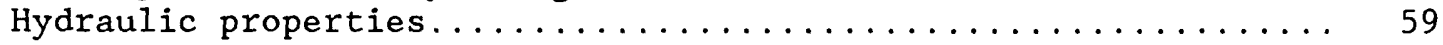

Description of wells that tap the system...............63

Potentiometric surface............................ 64

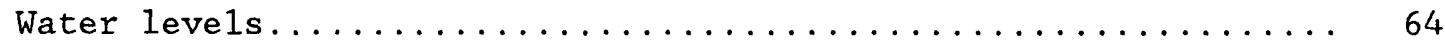

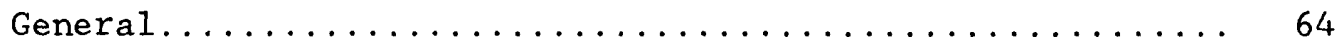

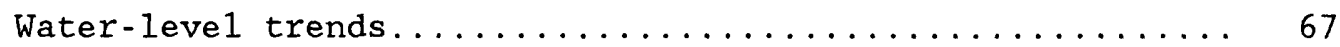

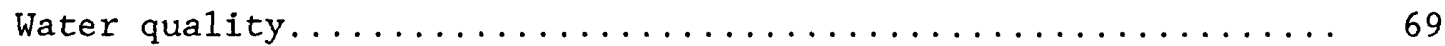

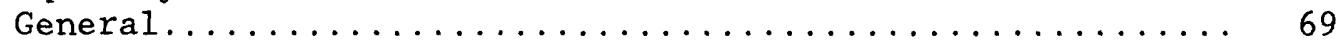

Variations of chloride concentration in wells......... 71

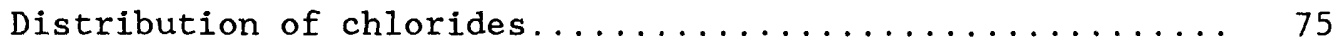

Trends in chloride concentrations................ 78

Effect of irrigation water from the Floridan

aquifer system on the quality of canal water......... 81

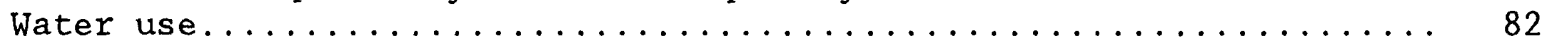

General. ................................. 82

Use of water from the Floridan aquifer system for

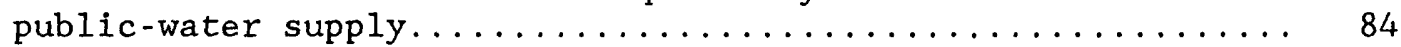

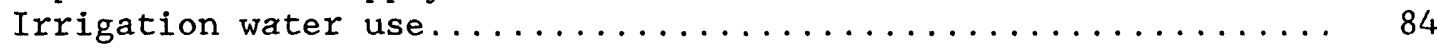

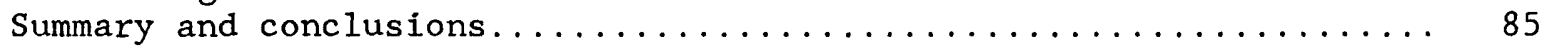

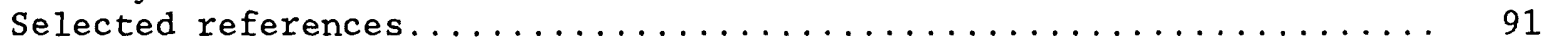

Supplementary data I--Wells in the surficial aquifer system

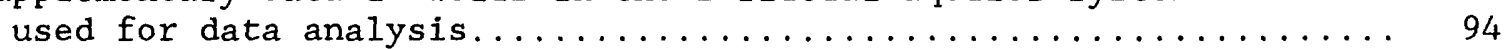

Supplementary data II--We1ls in the Floridan aquifer system used for data analysis.............................104 


\section{FIGURES}

1-5. Maps showing:

1. Indian River County - -the study area............... 4

2. Location of wells in the surficial aquifer system...... 6

3. Location of wells in the Floridan aquifer system....... 7

4. Land forms in Indian River County ................. 9

5. Comparison of marsh areas in the Upper St. Johns River basin, (predevelopment (1900) and 1972 (from

6-8. Graphs showing:

Campbe11 and others, 1984)................ 10

6. Annual rainfall at Vero Beach, 1943-85, and

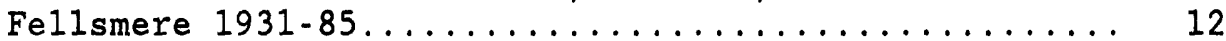

7. Monthly rainfall at Vero Beach, 1975-85, and

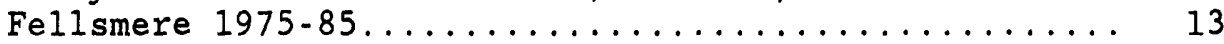

8. Annual rainfall and cumulative departure from monthly average rainfall at Blue Cypress Lake, 1979-85...... 14

9. Gamma-ray $\log$ of well $46 \mathrm{~F}$ showing geologic formations

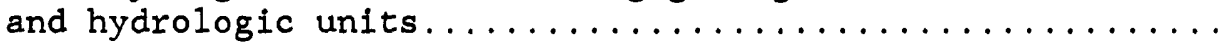

10-12. Hydrogeologic sections:

10. $A-A^{\prime}$ and $B-B^{\prime}$ showing components of the

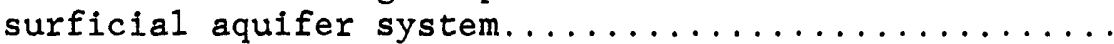

11. I $I-I^{\prime}$ and $J-J$ ' showing formations of the Floridan aquifer system................. 19

12. $\mathrm{K}-\mathrm{K}^{\prime}$ showing formations of the Floridan

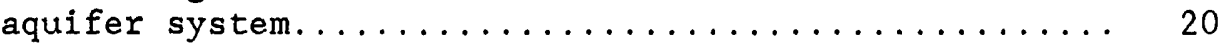

13-14. Maps showing:

13. Thickness of the Hawthorn Formation (intermediate

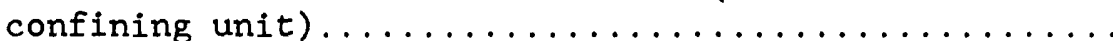

14. Potentiometric surface, May 1981, and areas of natural recharge and discharge of the

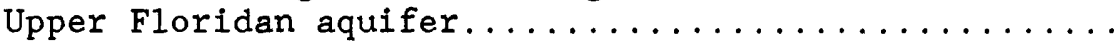

15-17. Graphs showing:

15. Classification of salinity and limiting concentrations of chloride recommended for plants, animals, public supply, and industrial use.........

16. Relation between chloride concentration and specific conductance......................

17. Relation between specific conductance and dissolvedsolids concentration, and the classification

18-22. Maps showing:

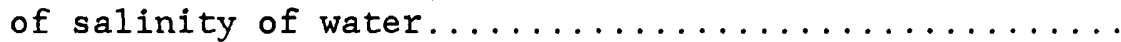

18. Thickness of the surficial aquifer system.......... 27

19. Generalized thickness of the Tamiami Formation........ 28

20. Specific capacity of wells completed in the surficial aquifer system and location of aquifer test sites in eastern Indian River County...........

21. Specific capacity of wells completed in the surficial aquifer system and locations of production wells and monitor wells in the Vero Beach well field.......

22. Locations of wells in the surficial aquifer system for which hydrographs are shown, and lines of

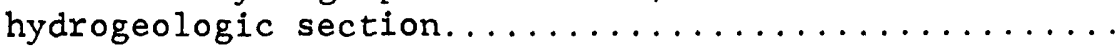

23-24. Hydrographs showing:

23. Water level in wells $316 \mathrm{~S}, 239 \mathrm{~s}$, and $134 \mathrm{~S} \ldots \ldots \ldots \ldots \ldots . \ldots . \ldots$

24. Water level in wells $151 \mathrm{~s}$ and $217 \mathrm{~s} \ldots \ldots \ldots \ldots \ldots \ldots \ldots$ 
25-26. Maps showing:

25. Potentiometric surface of the surficial aquifer system in the Vero Beach well field, May $1981 \ldots \ldots \ldots$.

26. Potentiometric surface of the surficial aquifer system in the Vero Beach well field, May $1984 \ldots \ldots \ldots$.

27-30. Graphs showing:

27. Water level and chloride concentration of water in well $121 \mathrm{~S}$ in the Vero Beach well field,

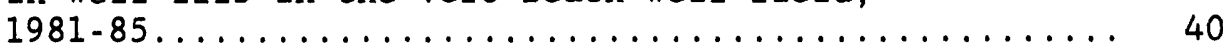

28. Monthly pumpage from the Vero Beach

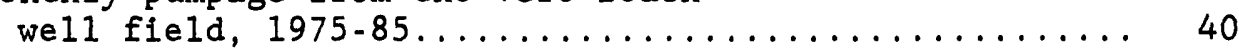

29. Water level and chloride concentration of water in well 100s, and stage of Main Canal, 1980-84......

30. Water level and chloride concentration of water in well 145S, and monthly rainfall at Vero

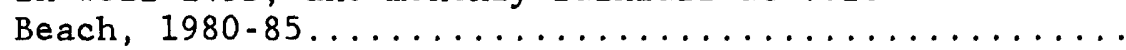

31-33. Maps showing:

31. Chloride concentrations in water from wells completed in the shallow rock zone (depths greater than 75 feet), $1982-83 \ldots \ldots \ldots \ldots \ldots \ldots \ldots$

32. Chloride concentrations in water from wells completed in the clastic zone (depths between 40 and 75 feet), $1982-83 \ldots \ldots \ldots \ldots \ldots \ldots$

33. Location of lines of chloride sections..............

34-35. Sections showing chloride concentrations in water and depth of wells in the surficial aquifer system along lines of section:

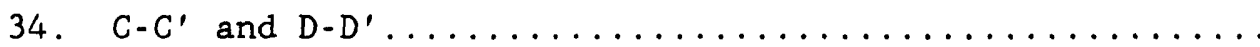

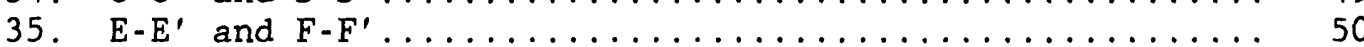

36. Section showing chloride concentration in water and depth of wells in the surficial and Floridan aquifer systems along line of section G-G' $^{\prime}$ (line of section

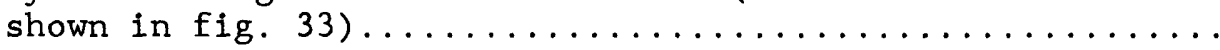

37. Section showing chloride concentration in water and depth of wells in the surficial aquifer system along line of section $\mathrm{H}^{-\mathrm{H}^{\prime}}$ (line of section shown in fig. 33 )...

38. Graph showing chloride concentrations in water from three salinity observation wells, 1979-84............

39-44. Maps showing:

39. Chloride concentrations in water from wells that tap the surficial aquifer system in the Vero Beach well field, June $1981 \ldots \ldots \ldots \ldots \ldots \ldots \ldots \ldots$

40. Chloride concentration in water from wells that tap the surficial aquifer system in the Vero Beach well field, June $1984 \ldots \ldots \ldots \ldots \ldots \ldots \ldots \ldots$

41. Altitude of the top of the Floridan aquifer system and western limit of the Suwannee Limestone.........

42. Specific capacity of wells completed in the Floridan aquifer system and location of aquifer

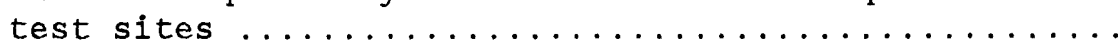

43. Potentiometric surface of the Upper Floridan

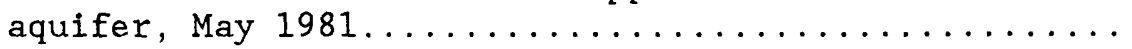

44. Potentiometric surface of the Upper Floridan aquifer, May 1983, and predevelopment surface (estimated)..... 
45-46. Hydrographs showing:

45. Month-end water levels in well 23F (USDA South Well

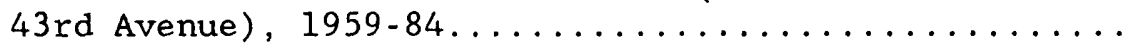

46. Water level in well $168 \mathrm{~F}$ (USGS

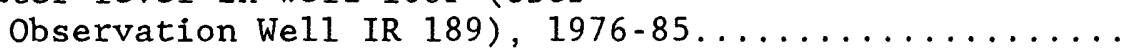

47. Map showing locations of wells in the Floridan aquifer

system for which hydrographs are shown, and lines of

hydrogeologic section......................

48. Graph showing chloride concentrations in water from continuously flowing and aperiodically flowing wells...... 72

49. Sketch showing hypothetical paths of ground-water movement in wells that penetrate both the

Upper and Lower Floridan aquifer.................. 74

50-52. Maps showing chloride concentrations in water from:

50. Wells that tap the Upper Floridan aquifer........... 76

51. We1ls that tap the Upper and the Lower

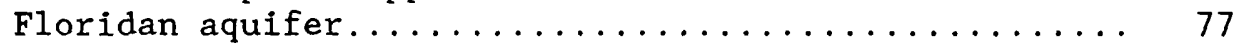

52. 26 wells that tap the Floridan aquifer system for the

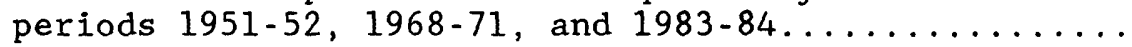

53-54. Graphs showing:

53. Specific conductance of water in South Canal at $43 r d$ Avenue and precipitation at Vero Beach.........

54. Annual pumpage by the city of Vero Beach, 1954-84..... 83

\section{TABLES}

1. Water-bearing characteristics and descriptions of the geologic units in Indian River County.............. 16

2. Aquifer-test results for the surficial aquifer system

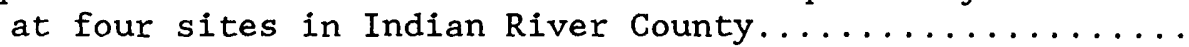

3. Water levels in wells in the clastic zone and shallow rock zone........................... 43

4. Representative analyses and ranges in concentrations of constituents in water from wells completed in the clastic and shallow rock zones of the

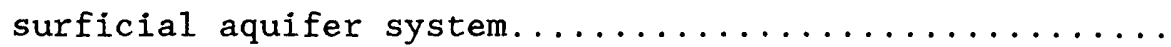

5. Transmissivities of the Floridan aquifer system at five sites in Indian River County................ 61

6. Specific capacity test data of selected wells that tap

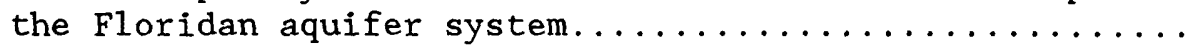

7. Ground-water levels at selected sites in Indian River and Highlands Counties, 1934, 1951, 1971, and 1984..... 


\title{
GEOHYDROLOGY OF INDIAN RIVER COUNTY, FLORIDA
}

By G.R. Schiner and C.P. Laughlin, U.S. Geological Survey; and D.J. Toth, St. Johns River Water Management District

\begin{abstract}
The surficial aquifer system and the underlying Floridan aquifer system are the sources of all ground water used in Indian River County, Florida. The surficial aquifer system consists of a 100-to 150-foot-thick section of unconsolidated clastic deposits termed the "clastic zone" that overlies a 0 - to 60 -foot-thick section of mostly indurated carbonate rock termed the "shallow rock zone." The Floridan aquifer system consists of about 2,800 feet of carbonate rocks, subdivided on the basis of permeability, into the Upper Floridan aquifer (about 350-650 feet thick), the middle semiconfining unit (about 20-120 feet thick), and the Lower Floridan aquifer (roughly 2,000 feet thick). The surficial and Floridan aquifer systems are separated by a 100 - to 200 -foot-thick low permeability rock unit known as the intermediate confining unit.
\end{abstract}

Transmissivities of the surficial aquifer system range from 1,500 to $11,000 \mathrm{ft}^{2} / d$ (feet squared per day). Specific capacities range from 21 to 70 (gal/min)/ft (gallons per minute per foot) in eastern Indian River County, and range from 9 to 36 (gal/min)/ft in the Vero Beach well field.

Pumpage in the Vero Beach well field approximately doubled during the 10-year period from 1975 to 1985 and peaked at about $9.5 \mathrm{Mgal} / \mathrm{d}$ (million gallons per day) in the spring of 1981, during a major drought. A comparison of water levels in the Vero Beach well field area between April 1971 and May 1984 indicates a decline of about 15 to 19 feet since 1971 .

Chloride concentrations in water from most wells that tap the surficial aquifer system in the Vero Beach well field have changed little in recent time. Between 1976 and 1983, the average chloride concentration in six production wells increased about $36 \mathrm{mg} / \mathrm{L}$ (milligrams per liter). However, chloride concentrations were unchanged in four others. The increase in chloride concentrations is probably related to the increase in well field pumpage from $5.44 \mathrm{Mgal} / \mathrm{d}$ in 1976 to $8.00 \mathrm{Mgal} / \mathrm{d}$ in 1983.

High yielding wells completed in the surficial aquifer system are most likely to be found along the coastal ridge west of U.S. Highway 1 in the eastern part of the county.

About 65 percent of all ground water used in the county is from the Floridan aquifer system. The hydrology of the Floridan aquifer system is complex. Considerable variation in yield and water quality may be found in nearby wells of equal depth. The permeability of the Upper Floridan aquifer generally is higher than that of the Lower Floridan aquifer. 
Transmissivities of the Upper Floridan aquifer estimated from computer model simulations range from about 65,000 $\mathrm{ft}^{2} / \mathrm{d}$ to $200,000 \mathrm{ft}^{2} / \mathrm{d}$. However, much higher transmissivities have been determined from aquifer tests at a few sites. One such aquifer test at an injection well completed in the socalled "Boulder Zone" of the Lower Floridan aquifer yielded a transmissivity of $1.5 \times 10^{6} \mathrm{ft}^{2} / \mathrm{d}$. Specific capacities of 37 wells in the Floridan aquifer system range from 1 to 200 (gal/min)/ft with a median of 67 ( $\mathrm{gal} / \mathrm{min}) / \mathrm{ft}$. Measured flow rates of wells that tap the Floridan aquifer system range from 30 to 2,000 gal/min (gallons per minute) with a median of $650 \mathrm{gal} / \mathrm{min}$.

Most wells completed in the Floridan aquifer system flow. In heavily pumped areas and during "dry" years, water levels in May are as much as 15 feet lower than the levels in September. Water levels in the more developed eastern part of Indian River County have declined about 16 to 24 feet in the 50 -year period 1934 to 1984. In the less developed western part of the county, water levels have declined about 8 to 10 feet. The countywide decline is probably mostly due to regional pumping. The water-level data indicate no significant water-level decline since the early $1970^{\prime} \mathrm{s}$ outside of local heavily pumped areas.

Water from the Lower Floridan aquifer generally contains chloride and dissolved solids in concentrations that exceed $250 \mathrm{mg} / \mathrm{L}$ and $500 \mathrm{mg} / \mathrm{L}$, respectively, but water from the Upper Floridan aquifer generally contains less than $250 \mathrm{mg} / \mathrm{L}$ chloride in much of the southwestern part of the county and in some areas along the Atlantic Coastal Ridge. High freshwater heads in the Floridan aquifer system (generally 10 to 30 feet above land surface) were, as of 1985, preventing saltwater in the Indian River, the Atlantic Ocean, and the saline aquifers that underlie the freshwater from migrating into the Floridan aquifer. The high heads also prevent contaminants on the land surface from moving downward into the Floridan aquifer system. In most of the county, chloride concentrations of wells that tap the Floridan aquifer system have not changed significantly in the 15-year period 1968-83. However, chloride concentrations in the water from two public-supply wells in the Floridan aquifer system at Vero Beach increased 35 and 60 percent in the past 6 and 9 years, respectively (1976 and 1979-85).

About 35 percent of the total area of Indian River County is in agricultural use, of which about 75 percent is irrigated. Irrigation withdrawals from the Floridan aquifer system amounted to $30 \mathrm{Mgal} / \mathrm{d}$ and constituted 22 percent of the total water used for irrigation in in the county in 1984. Inventoried irrigation wells range in depth from 233 to 1,272 feet-median depth is 700 feet. Changes in land use are affecting the pattern of irrigation. Urban development is replacing groveland along sections of U.S. Highway 1 and State Road 60 where irrigation water use is decreasing.

In 1984, about $8.5 \mathrm{Mgal} / \mathrm{d}$ of ground water were used for public supply in the county, mostly by Vero Beach. An additional $8 \mathrm{Mgal} / \mathrm{d}$ of ground water were used for domestic supply. In June 1985, the county-owned reverse osmosis treatment plant near Oslo has provided about $1 \mathrm{Mgal} / \mathrm{d}$ of water for public supply to its service area south and west of Vero Beach from two wells that tap the Floridan aquifer system. 


\section{INTRODUCTION}

\section{Background}

The 1980 population of Indian River County (fig. 1) was about 60,000, an increase of 67 percent from the 1970 population of 36,000 . The estimated 1985 population was about 76,000--a 300 percent increase in the 25-year period 1960-85 (University of Florida, 1986, p. 37). By the year 2000, the population is expected to reach about 104,000. Most new residents in the county have settled in the coastal areas, and this trend will probably continue. The predicted large population growth in the near future will cause a substantial additional demand for water from the shallow waterbearing surficial aquifer system, which underlies the coastal area and supplies much of the freshwater for public and private use. To augment supplies from the surficial aquifer system, additional substantial withdrawals from the commonly salty, deeper part of the Floridan aquifer system will probably be made for conversion to freshwater by the reverse osmosis process.

The surficial aquifer system and the Floridan aquifer system are the sources of all ground water used in Indian River County. The two systems contain ground water that ranges in salinity from fresh to brine. High chloride concentration is the chief water-quality problem in the county.

Prior to this study, little was known about the severity of stress imposed on the surficial and Floridan aquifer systems since large developments began in the $1970^{\prime} \mathrm{s}$. Drainage or diversion of surface water and changes in land use that accompany development may have altered the historical water balance that existed in the past. The effect of saline water flood irrigation on the water quality of the surficial aquifer system was not known.

High water levels, substantially above sea level, have historically kept saltwater in the coastal areas from moving laterally inland and infiltrating the potable water zones in the Floridan aquifer system. However, excessive pumping and diminishing recharge caused by changing land use can lower water levels enough to cause salty water to move into both the surficial and the Floridan aquifer systems.

The water-resources information needed to assess the effects of these changes was elther lacking or outdated, so a comprehensive and current framework of water-resources information was needed to allow orderly planning and management, and use of the resource.

\section{Purpose and Scope}

The purpose of this report is to describe the principal water-bearing and water-quality features of the surficial and Floridan aquifer systems. The report includes descriptions of the geology and geography as they relate to the geohydrology of the county. It contains information on the water quality and hydraulic properties of the surficial and Floridan aquifer systems and describes trends in water levels and chloride concentrations in the aquifer systems. 


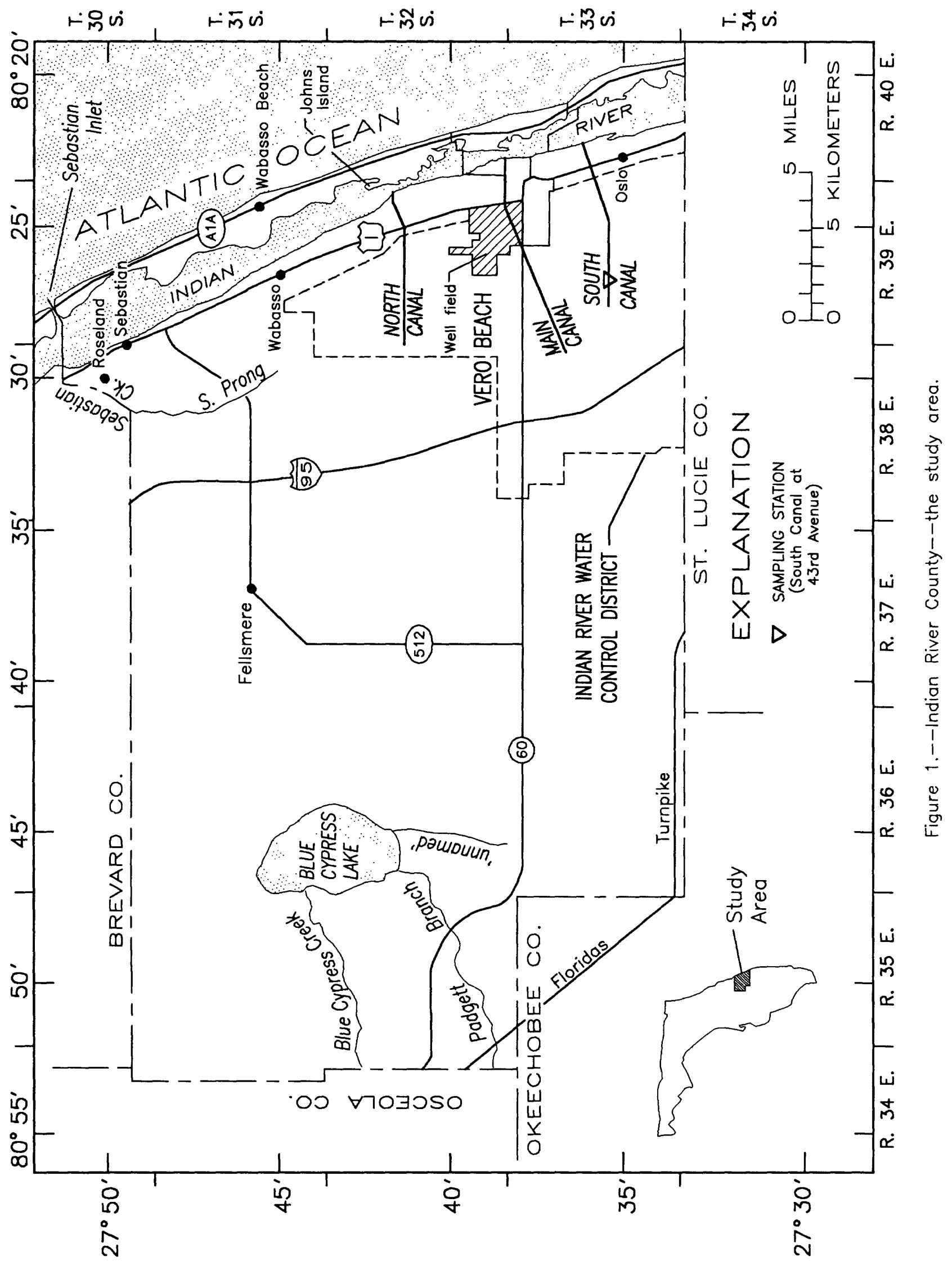


The section of the report describing the surficial aquifer system was prepared by D.S. Toth, St. Johns River Water Management; the section describing the Floridan aquifer system was prepared by Schiner and Laughlin of the U.S. Geological Survey. The description of the surficial aquifer system primarily describes the aquifer as it occurs in eastern Indian River County. This report includes data from reports and files of both of these agencies and from reports from other governmental agencies, and private consultants.

\section{Study Approach}

During this study, water levels were measured periodically in about 60 we1ls. Water-level recorders were installed on five new observation wells and reinstalled on two previously discontinued long-term observation we11s. Wells were inventoried and well logs obtained from owners and drillers. Fifty-three geophysical well logs were run and 25 test wells were drilled. Specific capacity tests were run on 35 wells that tap the Floridan aquifer system. The water-quality characteristics of selected wells were determined and about 300 wells were sampled for chloride analysis. In addition, the existing water-quality data for about 125 we 11 s were further analyzed. Wells sampled during the 1958 and 1975 studies were resampled for determination of chloride concentration. Specific conductance and fielddetermined chloride concentration measurements were periodically made at several sites on the canal system. Water-level and water-quality information provided by the city of Vero Beach was collated and analyzed.

Figures 2 and 3 show, respectively, the locations of wells in the surficial aquifer system and Floridan aquifer system used for data analyses in this report. Data on the physical characteristics of the wells are given in the sections supplementary Data I (surficial aquifer system) and Supplementary Data II (Floridan aquifer system) at the end of the report.

\section{Acknowledgments}

The authors gratefully acknowledge the assistance given by many organizations and individuals during the study. Valuable assistance was provided by Hillman Goff, Vero Beach Water and Sewer Department; and Art Chalacombe, Planning and Human Resources, Indian River County. McLaughlin Well Drilling contributed valuable data. Cooperation of the many well owners who permitted access to their wells for testing and measuring is greatly appreciated.

\section{We11-Numbering Systems}

Three numbering systems are used to identify wells in this report. A number of up to three digits is used to identify wells and test holes in illustrations and tables. In the text, the well number is suffixed by the letters "S" or "F" to indicate an inventoried well in the surficial aquifer system or a well in the Floridan aquifer system, respectively. A 15-digit number based on latitude and longitude is used to identify wells in the U.S. Geological Survey data storage and retrieval systems. The St. Johns River Water Management District uses a similar identification system to the U.S. Geological Survey, using latitude and longitude as a primary identifier. 


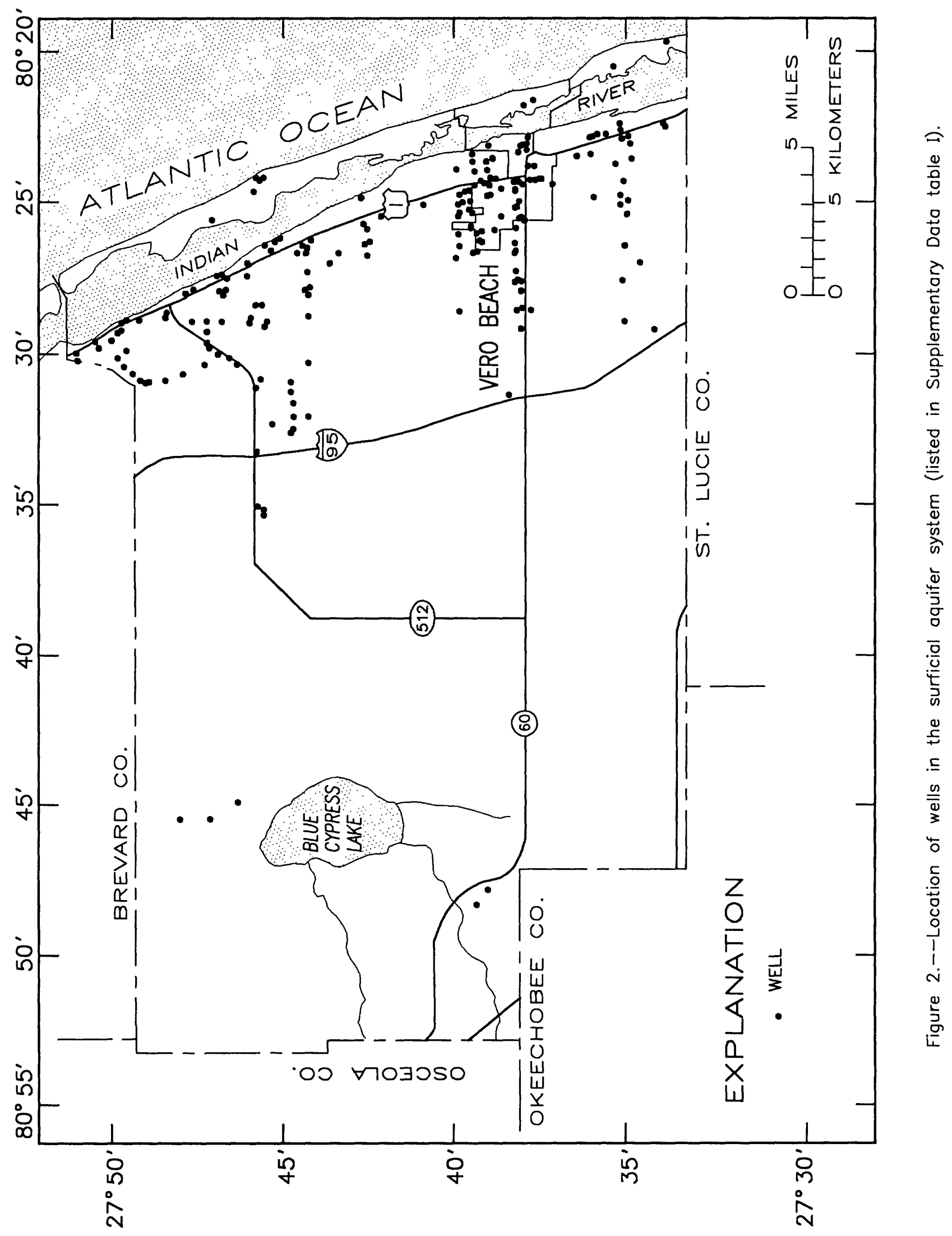




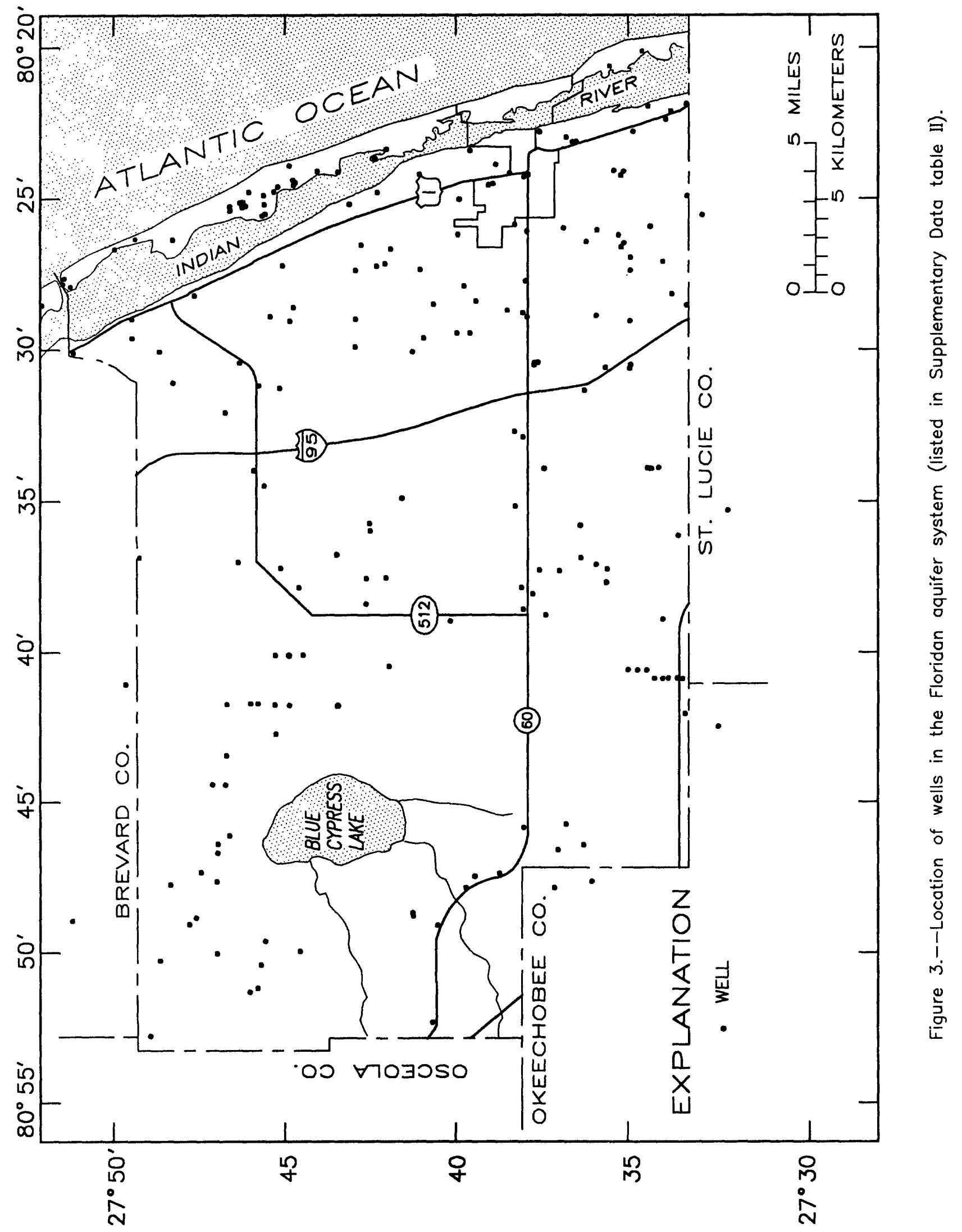


The 15-digit number is the customary ground-water site indentification system (GWSI) of the U.S. Geological Survey, providing a unique number for each station. The number consists of 15 digits, formed from the latitude and longitude of the station location. The first 6 digits denote the degrees, minutes, and seconds of latitude; the next 7 digits denote degrees (always 3 digits beginning with 0 ), minutes, and seconds of longitude; and the last 2 digits denote a sequential number for a station within a 1 -second grid. Once assigned, a site identification number does not change even though the locations determined by latitude and longitude may be revised later. The site identification number is the major vehicle used in placing and retrieving data from the U.S. Geological Survey's data management system, the National Water Data Storage and Retrieval (WATSTORE) System.

\section{GEOGRAPHY}

\section{Land Forms and Drainage}

The major land forms in Indian River County evolved during Pleistocene time and are of two general types--extensive terraces, and much less commonly, ridges. Terraces are steplike flatlands and scarps that were formed by ancient seas that stood at several levels. The ridges represent shoreline features such as offshore bars and relict beaches of the ancient seas. The shape of the land surface has been little modified since Pleistocene time. Figure 4 shows the major land forms found in Indian River County.

The Silver Bluff terrace extends from the coast to the Atlantic Coastal Ridge. The terrace includes the Barrier Island and stands at altitudes ranging from about 0 to 10 feet. The Pamlico terrace extends from the eastern edge of the Atlantic Coastal Ridge inland about 24 miles to the western edge of the St. Johns Marsh at generally near the 25-foot altitude. The St. Johns Marsh covers the western half of the Pamlico terrace. The Talbot terrace rises from the western edge of the St. Johns Marsh to altitudes that range from about 25 to 75 feet but is generally near the 50 -foot altitude.

The ridges from west to east are the Barrier Island, the Atlantic Coastal Ridge, and the Ten-Mile Ridge. The Barrier Island is a ridge that represents an ancient offshore bar in a section of the Atlantic Coastal Ridge system. The ridge on the Barrier Island ranges in altitude from 0 to about 25 feet but generally is less than 10 feet. The low area between the Barrier Island and the Atlantic Coastal Ridge is an ancient lagoon now occupied by the Indian River. The Atlantic Coastal Ridge ranges in altitude from about 5 to 50 feet--mostly 20 to 30 feet. The Ten-Mile Ridge ranges in altitude from 25 to 30 feet, and stands roughly 10 feet above the underlying Pamlico terrace. Descriptions of the geologic history and modes of occurrence of the terraces and ridges are given by Cooke (1945), MacNeil (1949), and White (1970).

Much of the surface drainage of Indian River County has been drastically modified since the $1900^{\prime}$ s and ongoing changes continue. Except for the Talbot terrace and the ridge areas, most of the county prior to development was marshland that drained northward. St. Johns Marsh comprised a large part of the headwaters of the St. Johns River. In recent decades, vast sections of the St. Johns Marsh and other marshy areas were diked, 


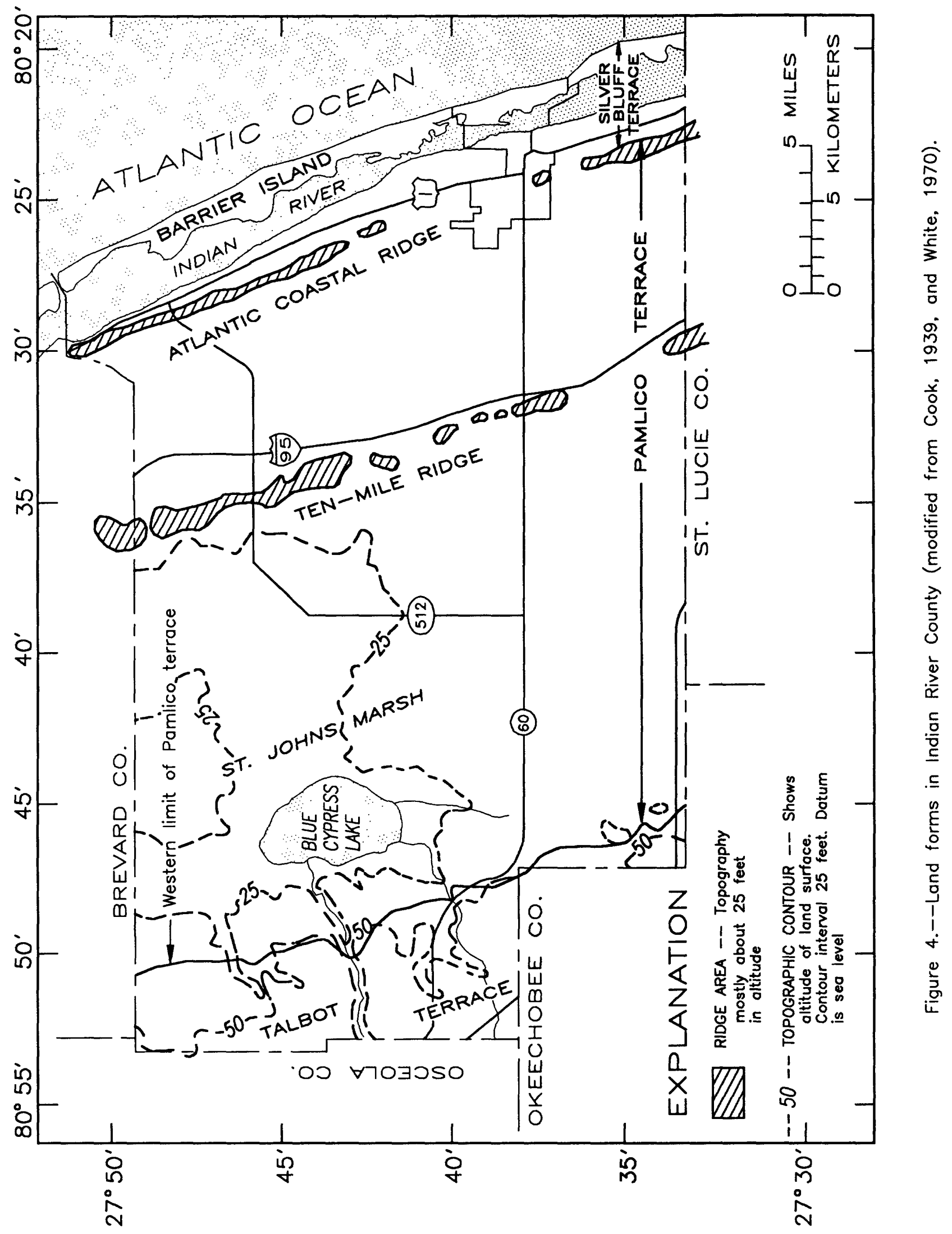


channeled, and drained to accommodate agricultural use. A comparison of marsh areas in 1972 to predevelopment marsh areas (about 1900) is shown in figure 5 .

Natural drainage in the county is sparse, but the following natural features were present in 1985. South Prong Sebastian Creek, paralleling the western side of the Atlantic Coastal Ridge, is tributary to Sebastian Creek that empties into the Indian River west of Sebastian Inlet. Blue Cypress Creek and Padgett Branch flow into Blue Cypress Lake from the highland of the Talbot Terrace west of the lake. Blue Cypress Lake has a surface area of $10.2 \mathrm{mi}^{2}$ (square miles) and has no defined natural outlet. Discharge from the northern end of the lake is controlled by a structure. A system of levees and drainage ditches that surround Blue Cypress Lake allows the adjacent land to be used for agriculture.
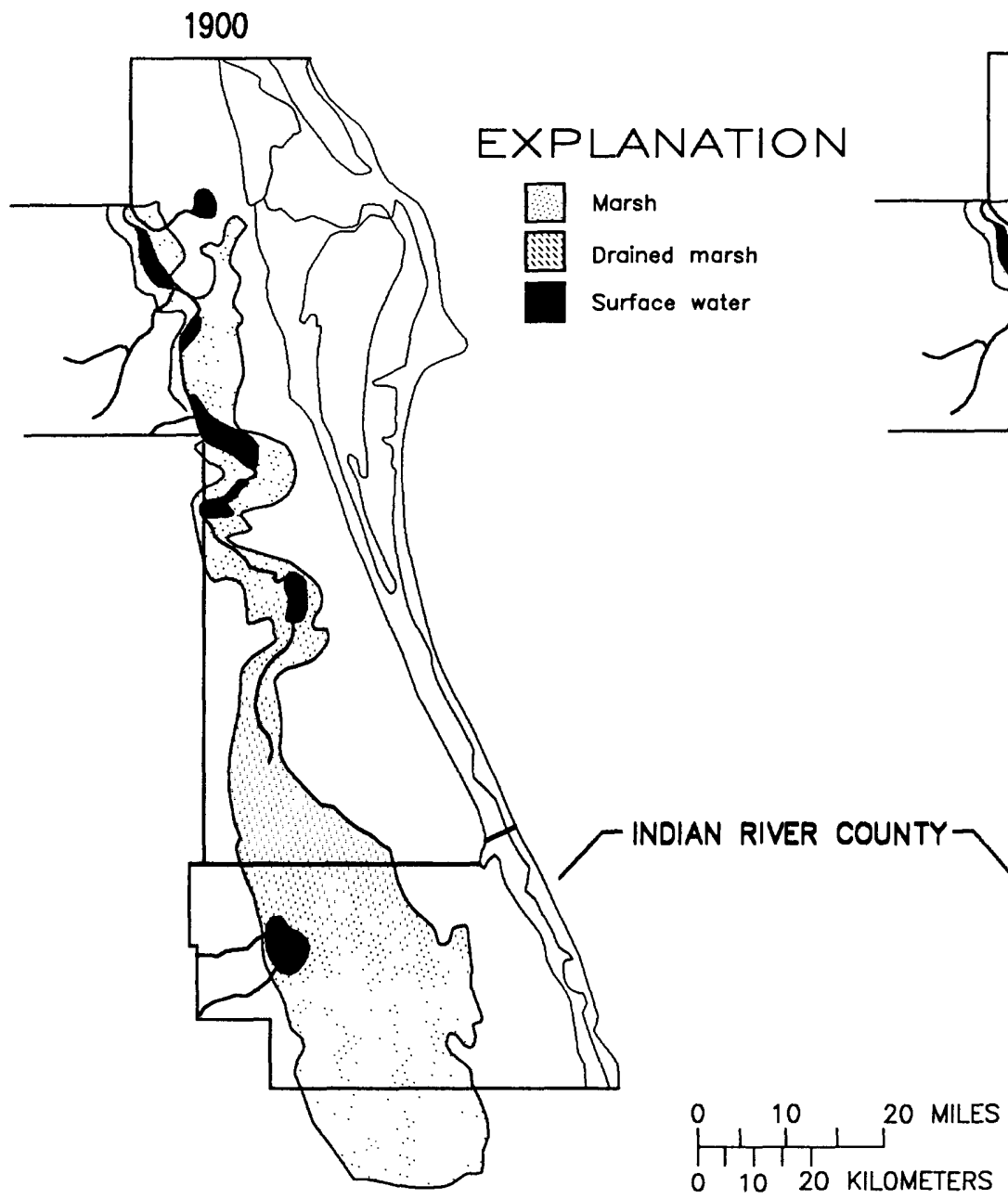

\section{2}

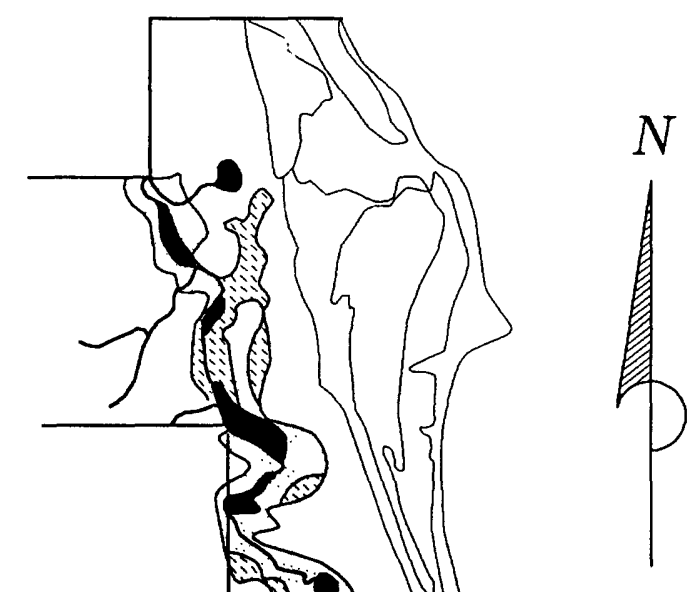

INDIAN RIVER COUNTY

Figure 5.--Comparison of marsh areas in the Upper St. Johns River basin, predevelopment (1900) and 1972 (from Campbell and others, 1984). 
Presently (1985), most of the drainage in the county flows to the Indian River through a system of drainage ditches connected to three large east-trending canals that discharge into the river (fig. 1).

\section{Land Use}

Indian River County has an area of $549 \mathrm{mi}^{2}$. Land use in the county is closely related to its land forms (fig. 4). The Barrier Island and Atlantic Coastal Ridge are generally citrus groves, residential, and commercial developments. Prior to the 1970's, the Atlantic Coastal Ridge and Barrier Island were chiefly in citrus groves, but because of urban growth these groves are being replaced by residential and commercial developments, primarily along the major roadways--State Roads AlA and 60, and U.S. Highway 1 (fig. 1). The Pamlico terrace is generally either in agricultura1 use (citrus and some vegetable farming) or natural marshland. The Ten MileRidge is mostly in citrus groves. Large tracts of the St. Johns Marsh have been drained for citrus and vegetable farming and for cattle rangeland. Recently (1982-85) some of the drained rangeland is being developed for citrus production. The Talbot terrace is generally rangeland or undeveloped.

\section{Climate}

The climate of Indian River County is classified as subtropical humid, characterized by long, warm, mostly wet summers and mild, generally dry winters. The average annual air temperature is about $73^{\circ} \mathrm{F}$. High afternoon temperatures frequently exceed $90^{\circ} \mathrm{F}$ during the summer months. Most years have a few days of frost or freezing temperatures with winter temperatures lowest inland.

Rainfal1 is unevenly distributed throughout the year. Summer rainfall is from local showers or thunderstorms that are random in occurrence. Winter rainfall is generally associated with large, cold, frontal-type air masses that move from the northern latitudes southward. These fronts cover large areas so winter rainfall is more widespread than the summer rains. Occasional tropical storms or hurricanes may add considerable amounts of rainfall to the yearly average total rainfall. About 60 percent of the annual rainfall occurs in the period June through October.

National Oceanographic and Atmospheric Administration records indicate that rainfall is unevenly distributed areally within the county. Average yearly rainfall at Fellsmere (about 55 inches) is about 3 inches more than the average yearly rainfall at Vero Beach (about 52 inches). Annual rainfall for a station at Blue Cypress Lake for the period 1979 through 1985 averaged about 49 inches. Rainfall data at Vero Beach, Fellsmere, and B1ue Cypress Lake are shown in figures 6,7 , and 8 . Drought conditions prevailed throughout Florida during parts of 1980 and 1981 , causing a 2-year deficiency of about 19 inches from the average yearly at Vero Beach. At Avon Park, in Highlands County (fig. 14), the 2-year deficiency was about 26 inches. 

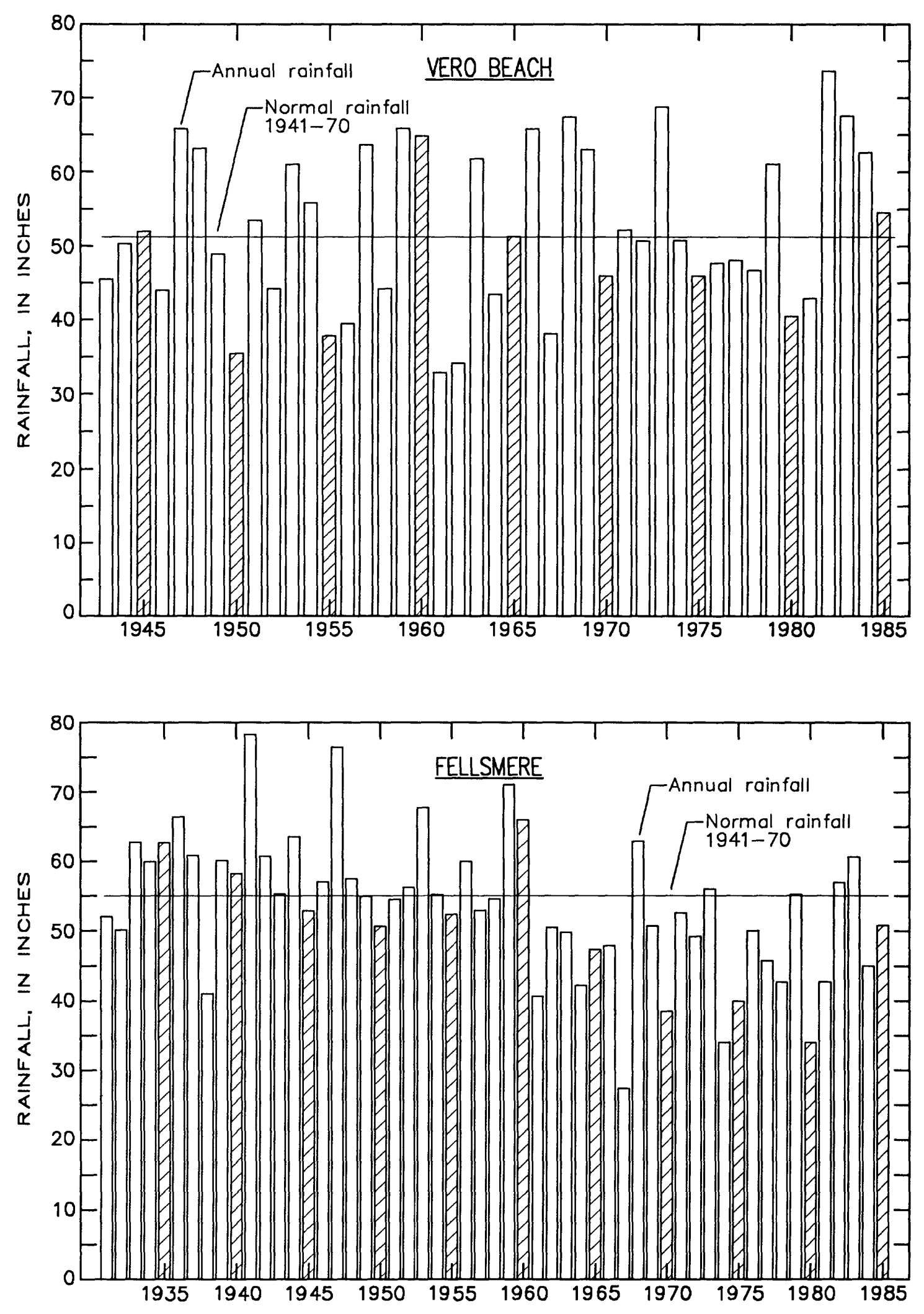

Figure 6.--Annual rainfall at Vero Beach, 1943-85, and Fellsmere, 1931-85. 

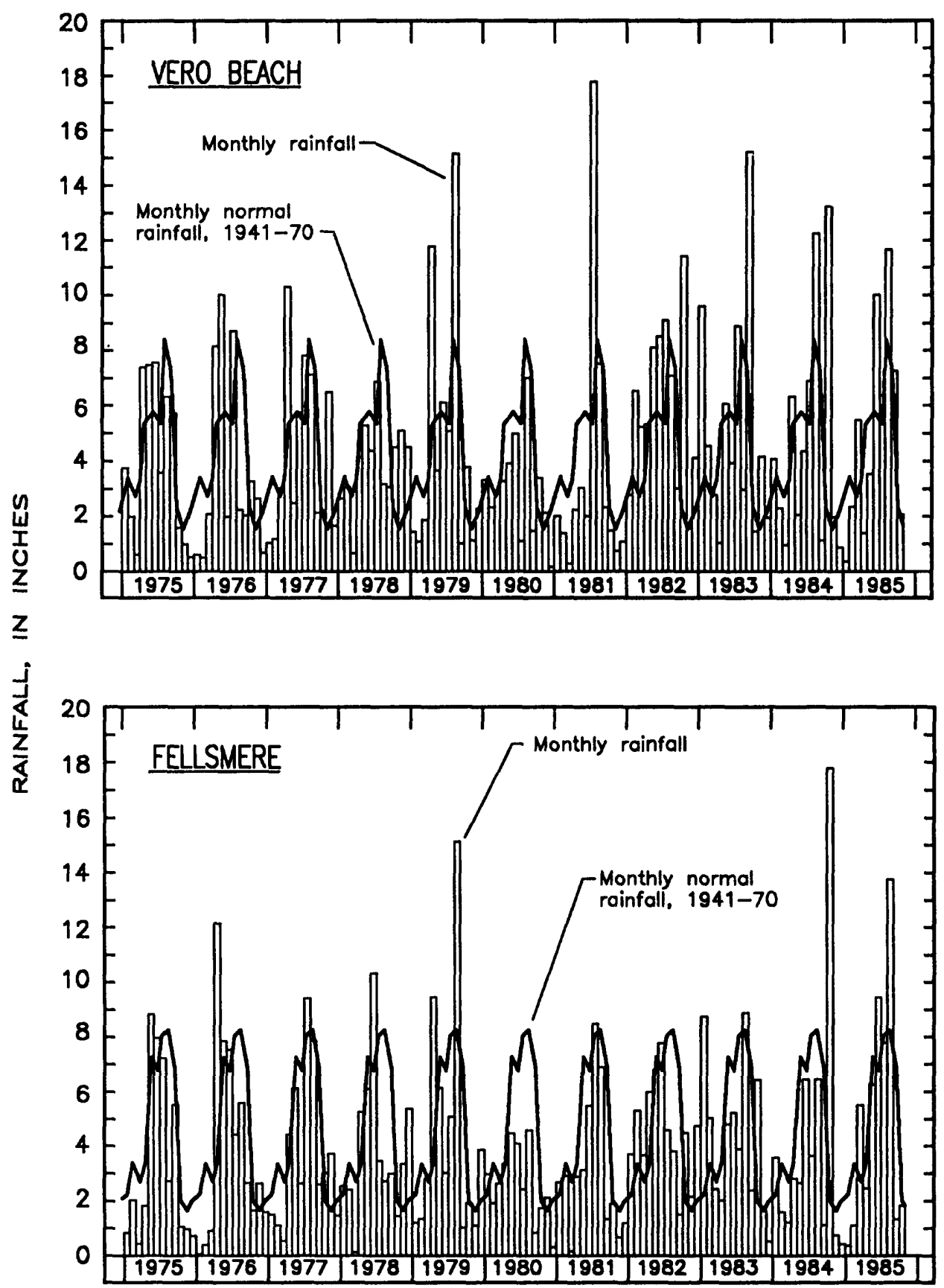

Figure 7.--Monthly rainfoll at Vero Beoch, 1975-85, and Fellsmere, 1975-85. 

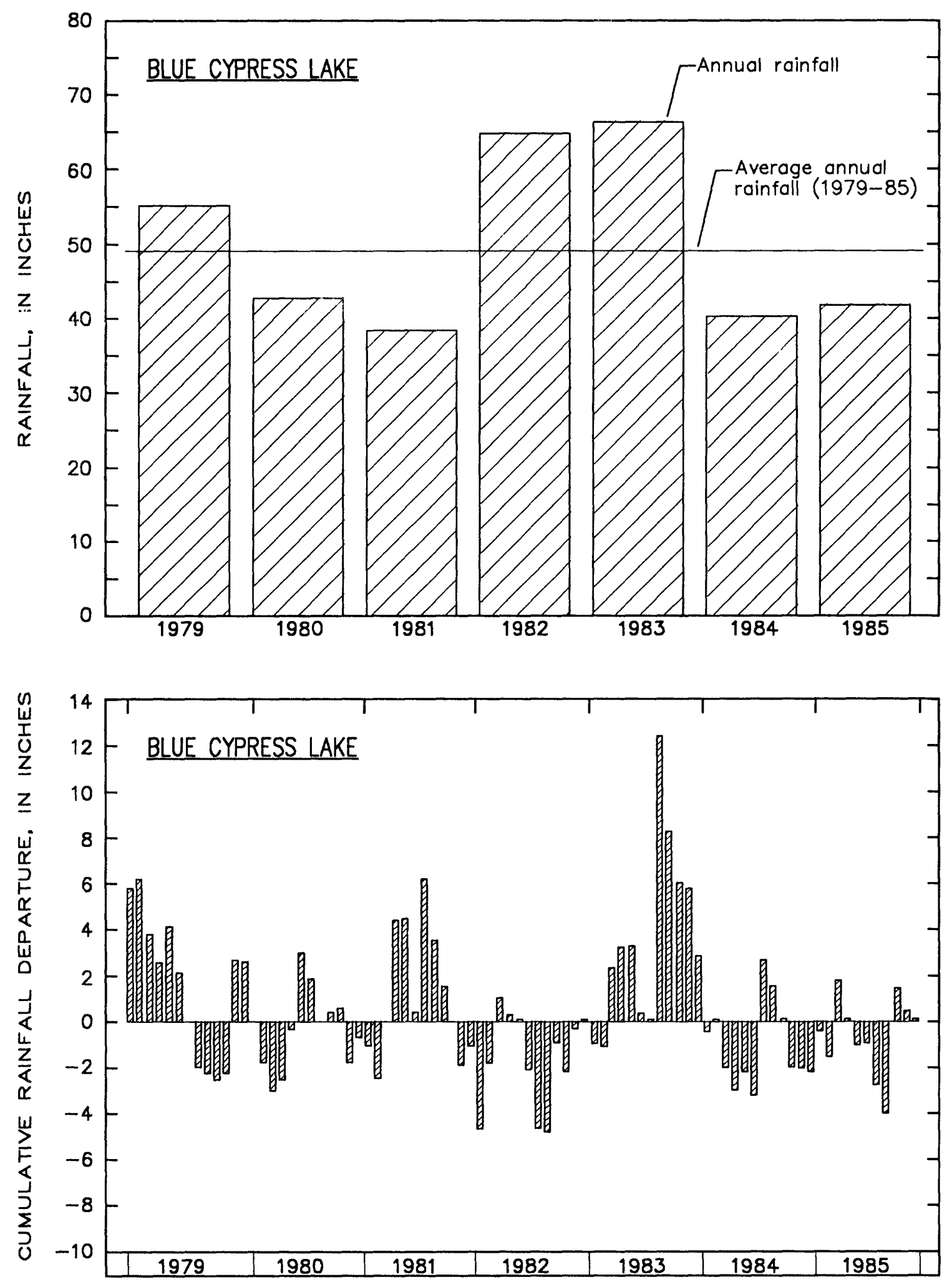

Figure 8.--Annual rainfall and cumulative departure from monthly average rainfall at Blue Cypress Lake, 1979-85. 


\section{GENERAL GEOHYDROLOGY OF THE GROUND-WATER SYSTEM}

\section{Geologic Framework}

The availability and quality of ground water and surface water is closely related to the geologic framework that underlies Indian River County. Sedimentary rocks about 9,500 feet thick (Lloyd, 1985, p. 57) rest on a basement complex of pre-Mesozoic volcanic rock. The top 1,500 feet of sediments, significant to this study, are part of the Tertiary and Quaternary systems that range in age from Eocene (oldest) to Holocene (youngest). The uppermost geologic deposits of the 1,500-foot section consist of unconsolidated post-Miocene deposits of sand, sandy clay, shell material and thin carbonate sediments that average about 150 feet in thickness. In descending order, the deposits consist of undifferentiated Holocene deposits, the Fort Thompson and Anastasia Formations of Pleistocene age, and the Tamiami Formation of Pliocene age. The unconsolidated deposits are underlain by fine clastic rocks of the Miocene Hawthorn Formation that range in thickness from about 70 to 250 feet in most of the study area. The fine clastic rocks are in turn underlain by either 01igocene or Eocene carbonate rocks about 1,000-feet thick that comprise the remainder of the 1,500-foot section. In descending order, the unit consists of the Suwannee Limestone, the Ocala Limestone, and the Avon Park Formation.

Descriptions of the geologic formations penetrated by wells in Indian River County are given in table 1. An interpretation of the subsurface geology, indicated by distinctive features of the gamma-ray $10 \mathrm{~g}$ of wel1 46F, is shown in figure 9. (For location of well 46F, see fig. 47.) The hydrogeologic sections shown in figures 10, 11 , and 12 indicate the thickness and extent of the geologic units located in the eastern part of the study area. (See figs. 22 and 47 for location of lines of section.)

\section{Hydrogeologic Framework}

The hydrogeologic framework, through which ground water moves and is stored, in the study area consists of two general types of rock units-consolidated carbonate rocks and the overlying unconsolidated rock. Each rock type contains aquifers with unique water-bearing properties that determine its utility as a source of water supply. The unconsolidated deposits contain the surficial aquifer system, commonly known as the surficial aquifer. The carbonate rocks contain the Floridan aquifer system, formerly known as the Floridan aquifer. The two aquifer systems are separated by a fine clastic unit that retards the exchange of water between them and is known as the intermediate confining unit (thickness is shown in fig. 13). The Floridan aquifer system has two major water-bearing zones separated by a less permeable confining unit (Tibbals, 1981, p. 7). In descending order, the aquifer system is divided into the Upper Floridan aquifer, the middle semiconfining unit, and the Lower Floridan aquifer (see fig. 9).

Geologic structure $c$ an be an important control in a ground-water flow system in Indian River County. The top of the Floridan aquifer system generally dips to the southeast and has an irregular, eroded surface. Consequently, the continuity of water-bearing zones that are structurally controlled may appear erratic in occurrence (fig. 41). 
Table 1. - Water-bearing characteristics and descriptions of the geologic units in Indian River County

$$
\text { [gal/min - gallons per minute] }
$$

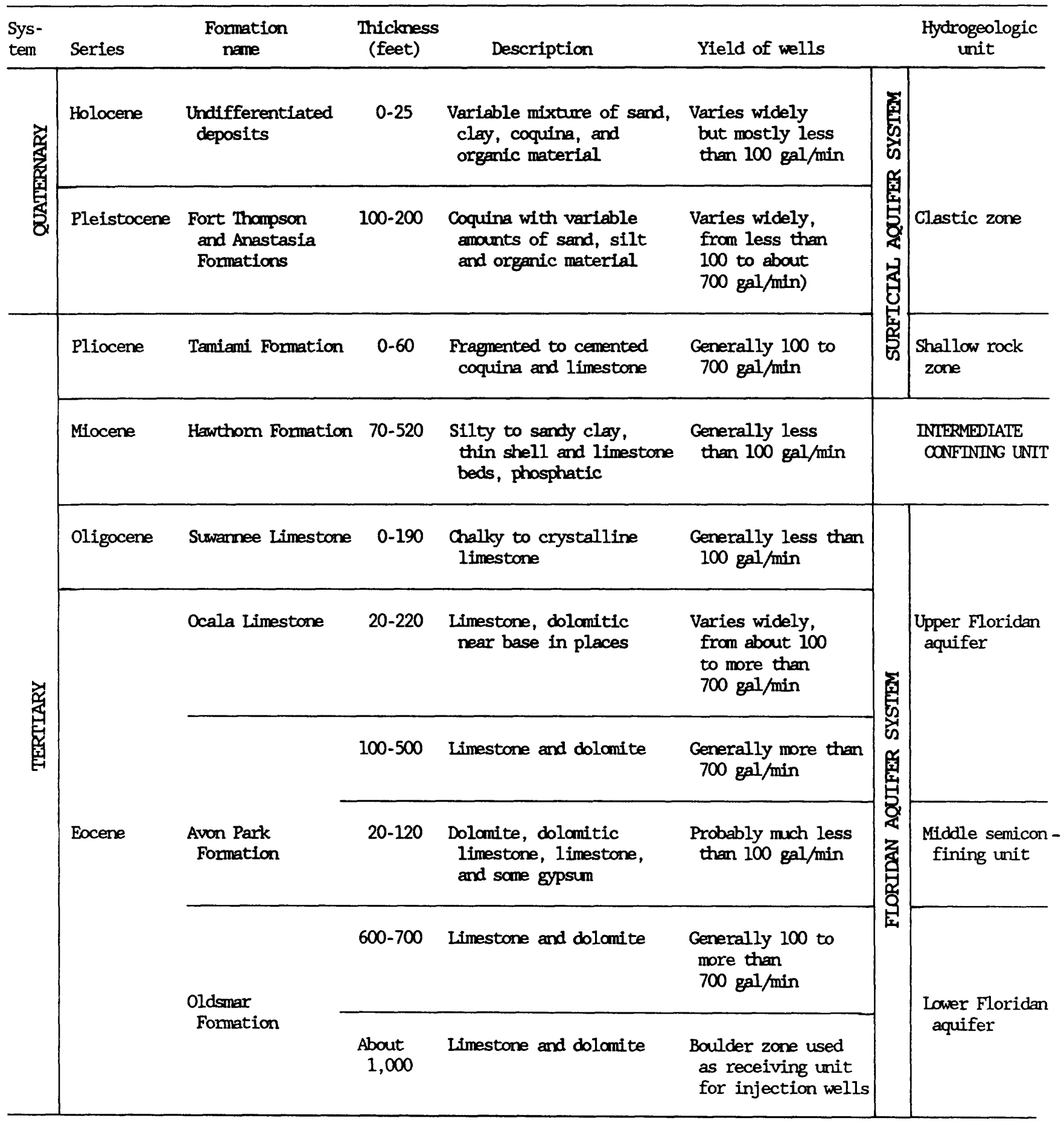




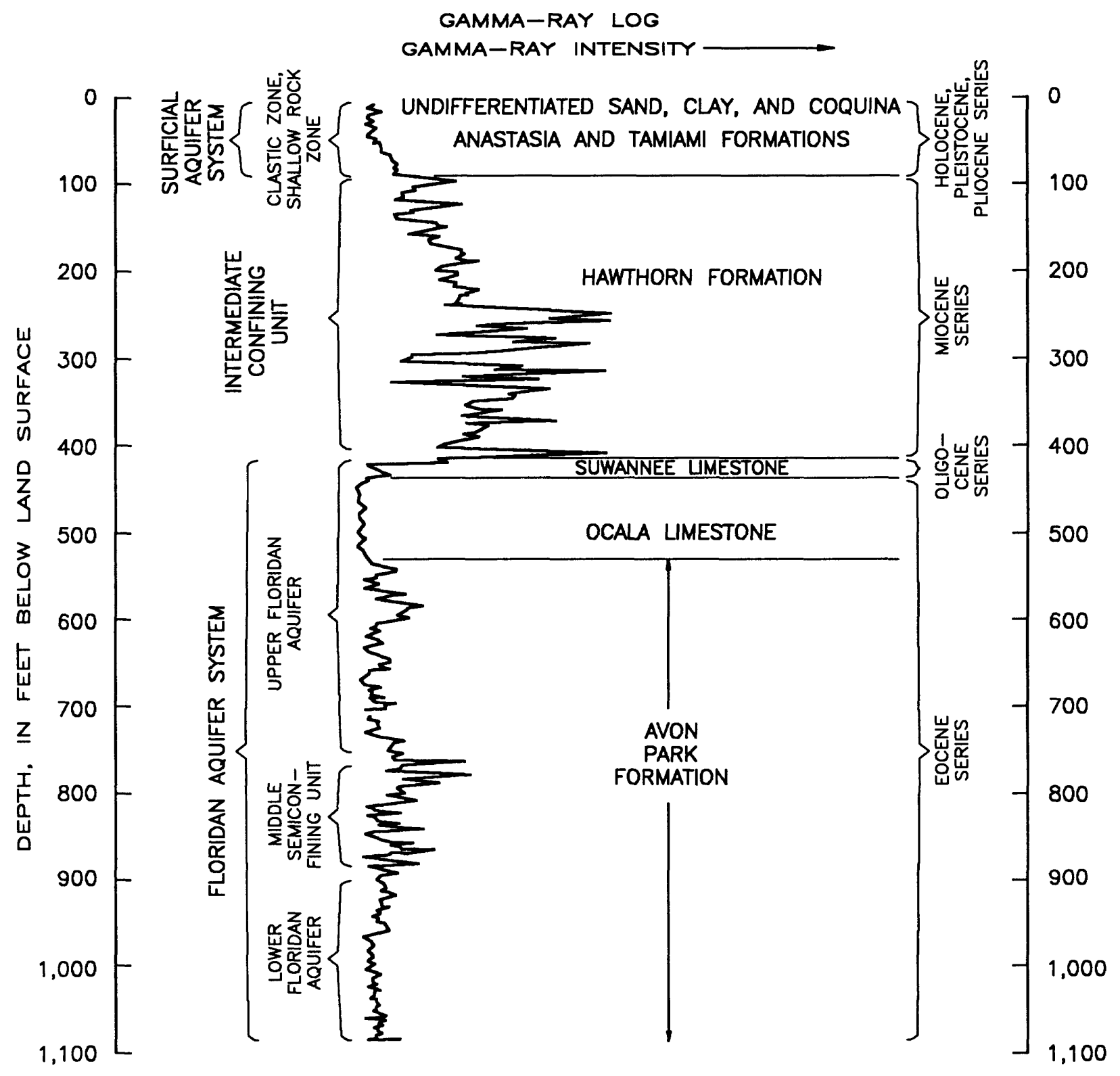

Figure 9.--Gamma-ray log of well $46 \mathrm{~F}$ showing geologic formations and hydrologic units.

Miller (1982) reports that the small faults along Florida's east coast have the overall effect of thinning the Floridan aquifer system on the upthrown side of the fault, but because displacement is small, the ground-water flow system is little affected. Only one of several faults reported as present in Indian River County by Bermes (1958, p. 8) was confirmed on the evidence of geophysical and driller's logs collected during this study. The fault extends approximately from the south-county line northward along the Indian River to about Johns Island where it may trend northeast (fig. 41). The displacement in the carbonate rock section is roughly 350 feet ( $f i g .11$ ). The effect of the fault on geohydrologic conditions identified in Indian River County is considerable. On the downthrown side (east of the fault trace), the upper part of the Floridan aquifer system contains brackish water. On the upthrown side, water from the upper part of the system is relatively fresh. 


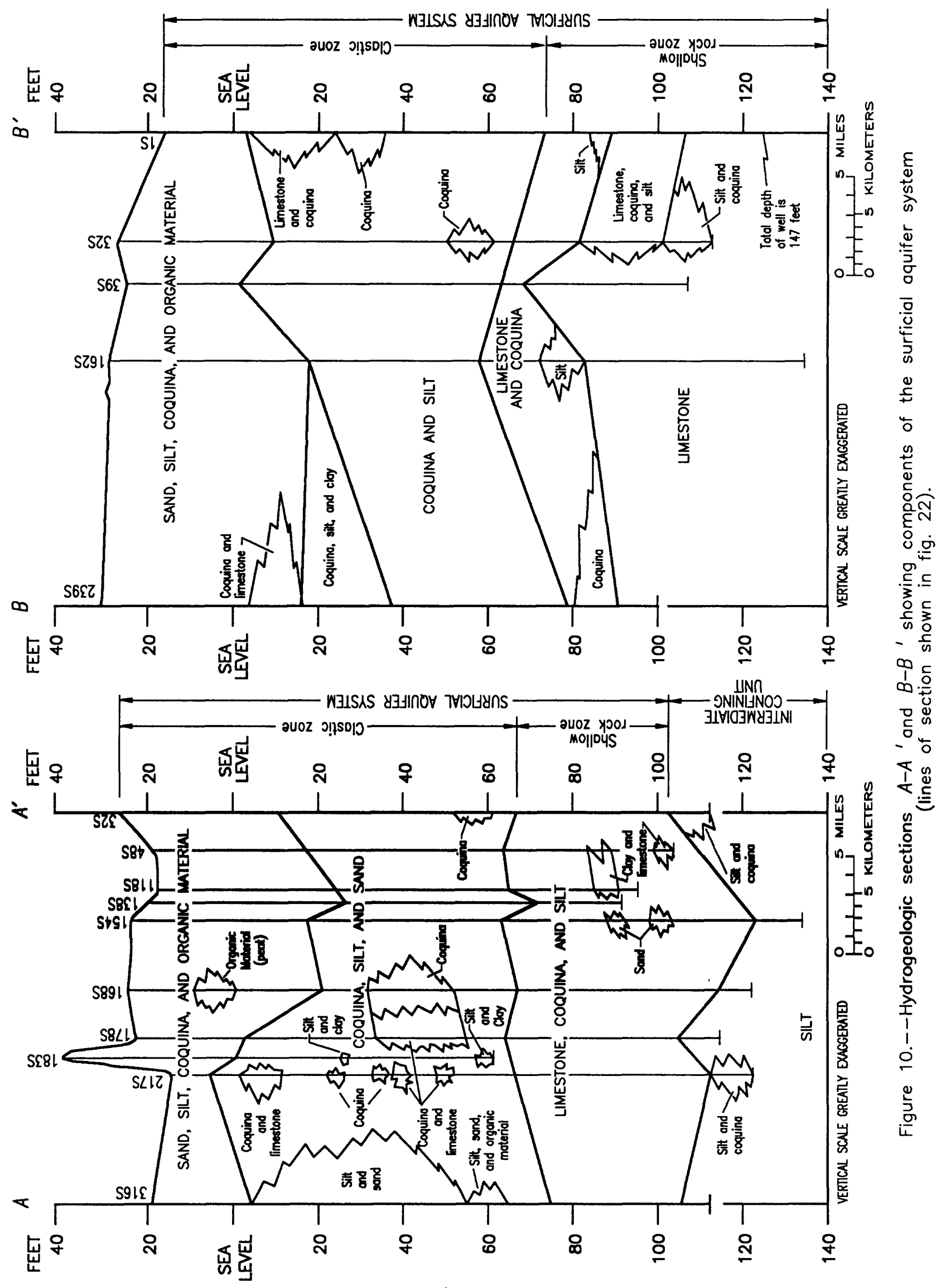



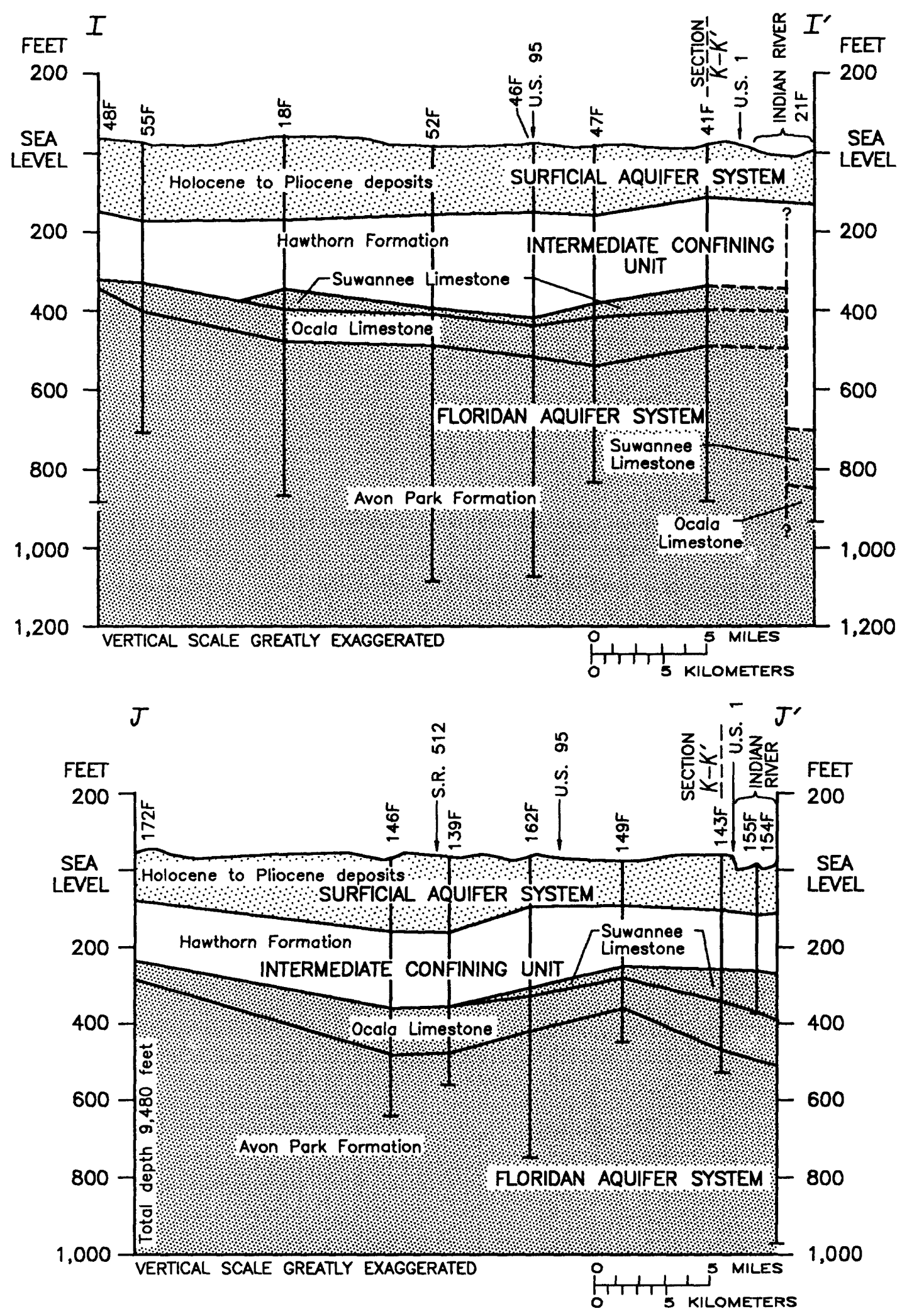

Figure 11.--Hydrogeologic sections $I-I^{\prime}$ and $J-J^{\prime}$ showing formations of the Floridan aquifer system (lines of section shown in fig. 47). 


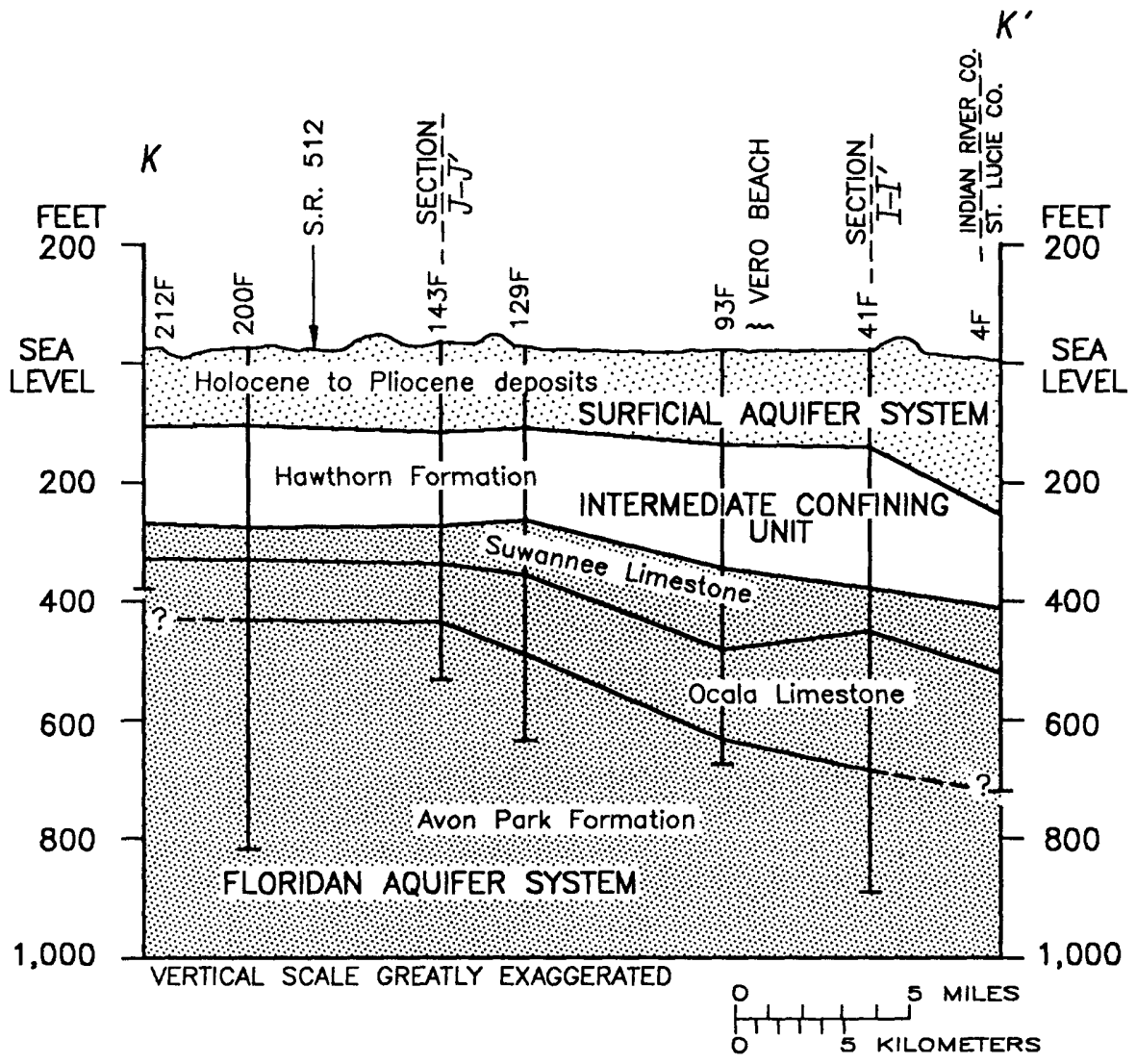

Figure 12.--Hydrogeologic section $K-K^{\prime}$ showing formations of the Floridan aquifer system (line of section shown in fig. 47).

\section{Ground-Water Occurrence and Movement}

Ground water in the surficial aquifer system is generally unconfined, but in the Floridan aquifer system the water is confined. The water table of the surficial aquifer system and the potentiometric surface of the Floridan aquifer system fluctuate continuously in response to changes in recharge and discharge. Most natural recharge to the surficial aquifer system is local precipitation in Indian River County, but most recharge to the Floridan aquifer system probably occurs in the Lake Wales Ridge area of eastern Polk and western Highlands Counties (fig. 14). Heads in the Floridan aquifer system are generally much higher than heads in the surficial aquifer system so recharge from the surficial to the Floridan aquifer system cannot occur in the county. Natural discharge from the surficial aquifer system generally occurs as evapotranspiration and subsurface flow into the Indian River and St. Johns Marsh. Most of the county is in the discharge area of the Floridan aquifer system. There, natural discharge is largely by way of upward leakage through the intermediate confining unit and probably some small amounts of discharge from the subcrop area beneath the Atlantic Ocean. 


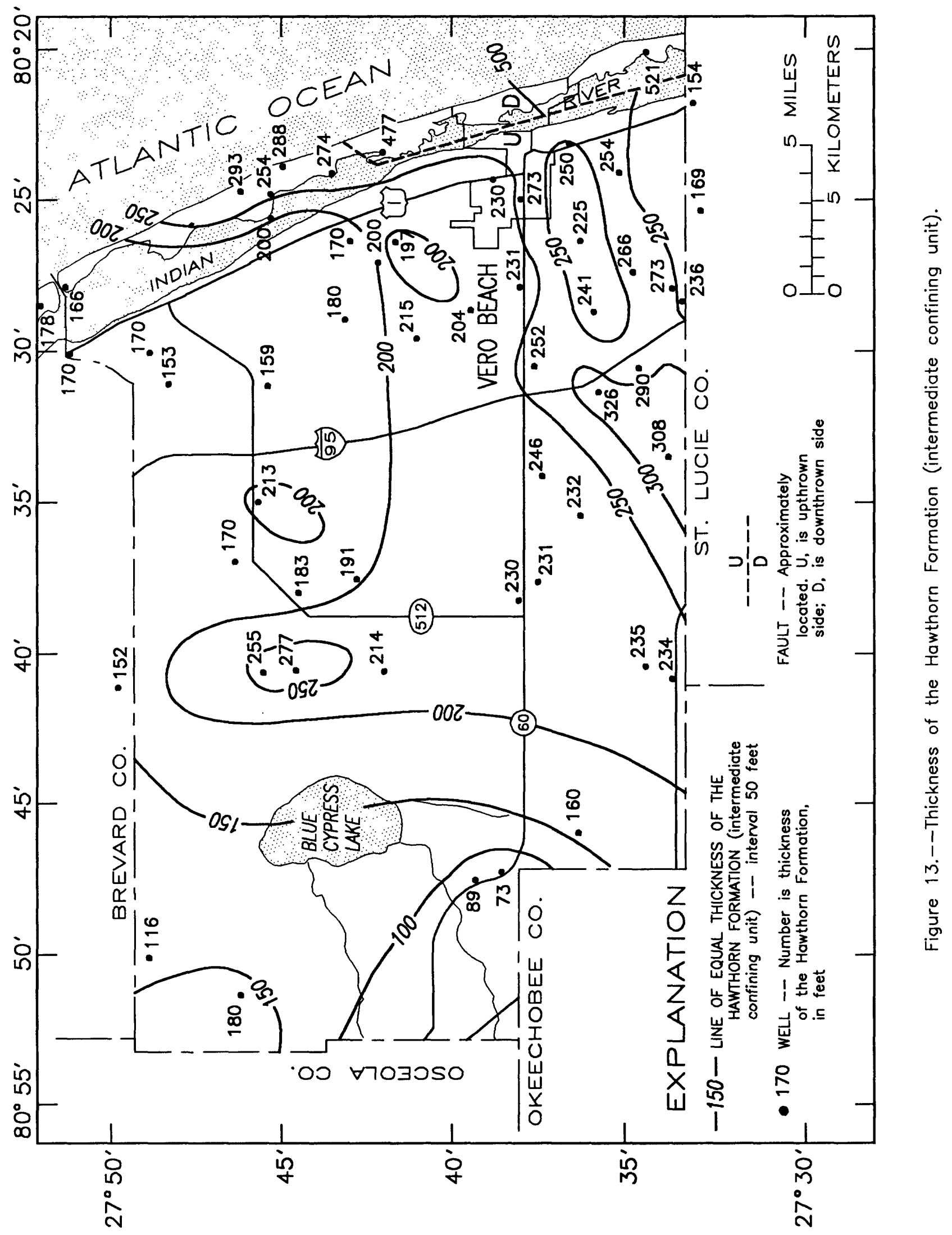




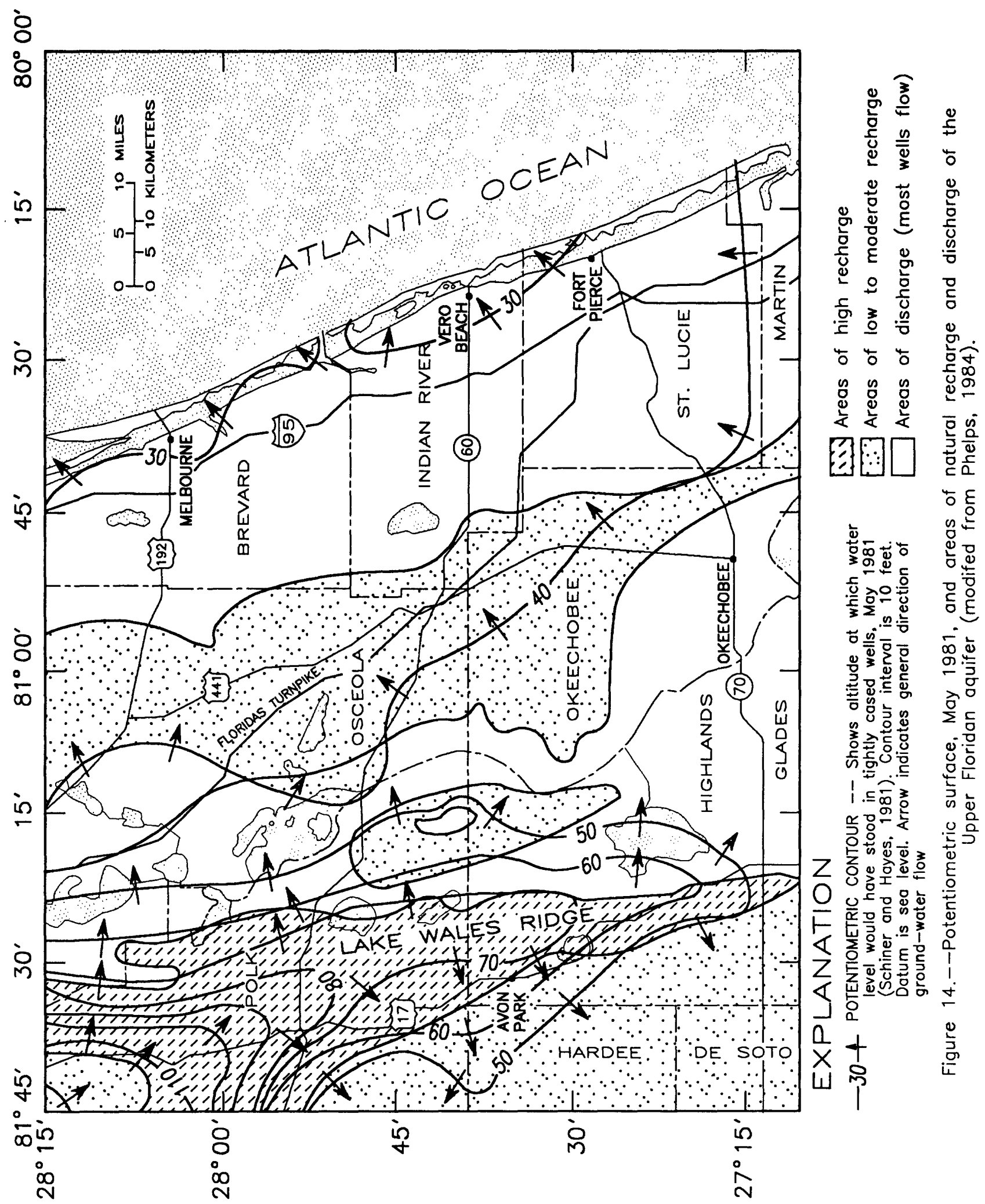




\section{Water Quality}

The amount, properties, and type of dissolved and suspended materials in water often control its use. Water suitable for one use may be unsatisfactory for other uses. For example, water having moderate amounts of dissolved solids may be used for irrigation purposes, but may not be suitable in the manufacture of high-grade paper which requires low dissolved solids. The chloride concentration and salinity of water in Indian River County are the most important limiting factors for public supply and agricultural use, which together account for more than 90 percent of the water used in the county. Chloride concentration is used in this report as an index to the overall quality of water in the county.

Chloride concentrations of water in the surficial and Floridan aquifer systems vary both areally and vertically because the geohydrologic conditions that control water quality differ to some degree from place to place. In this report, water with a chloride concentration of $250 \mathrm{mg} / \mathrm{L}$ or less is considered fresh; above $250 \mathrm{mg} / \mathrm{L}$, the water is considered salty. Figure 15 is a graph showing the limiting concentrations of chloride recommended for plants, animals, and industrial uses.

The terminology used to describe the salinity of water in the county is a classification based on dissolved-solids concentration and uses the terminology of Krieger and others (1957).

Estimates of dissolved-solids and chloride concentrations can generally be obtained relatively easily and inexpensively by measuring an electrical property of the water called specific conductance, which is a measure of the capacity of water to conduct an electric current. Specific conductance varies with the concentration of dissolved mineral matter, the degree of ionization of the material, and the temperature of the water, and is reported in microsiemens per centimeter at $25^{\circ} \mathrm{C}$. Figures 16 and 17 show, respectively, the relation between chloride concentration, and specific conductance and between specific conductance and dissolved-solids concentration. Data from Indian River County and nearby areas were used in plotting the graphs. Note in figure 16 that specific conductance is roughly three times the chloride concentration and in figure 17, that specific conductance is about one-and-a-half times the dissolved-solids concentration. In some less-mineralized waters, chloride may not be a major element and conductance may be more closely related to other constituents. At the left side, or low-range end of figure 16, the group of data indicating a change in slope of this graph reflects waters not dominated by chloride concentration.

Hardness is expressed in terms of milligrams per liter of calcium carbonate $\left(\mathrm{CaCO}_{3}\right)$. Water is considered soft if its hardness value lies between 0 and $75 \mathrm{mg} / \mathrm{L}$, moderately hard between 75 and $150 \mathrm{mg} / \mathrm{L}$, hard between 150 and $300 \mathrm{mg} / \mathrm{L}$, and very hard for values above $300 \mathrm{mg} / \mathrm{L}$ of $\mathrm{CaCO}_{3}$ (U.S. Environmental Protection Agency, 1976). 


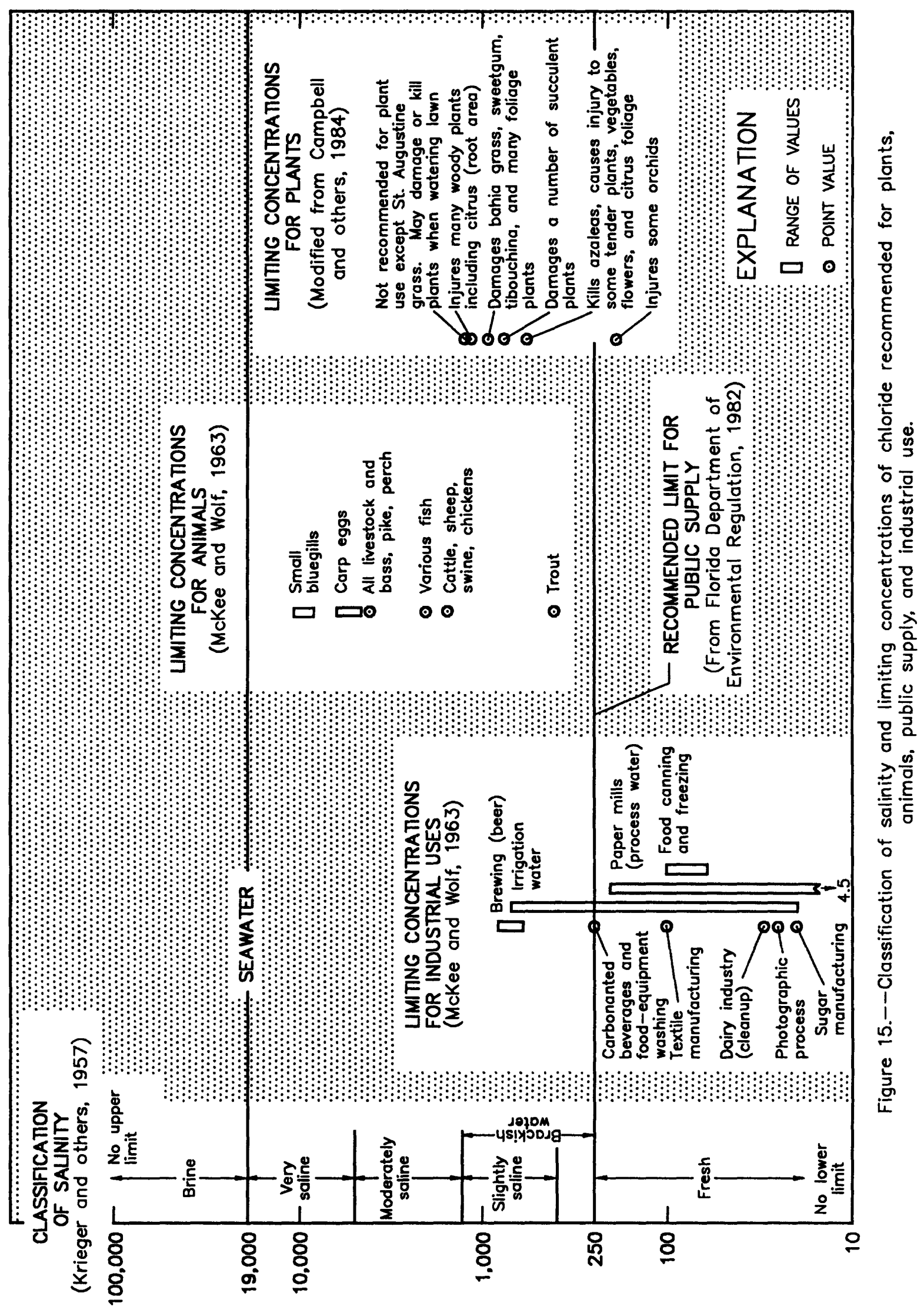

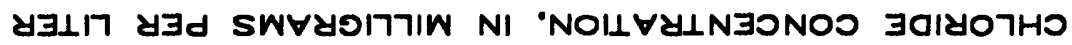




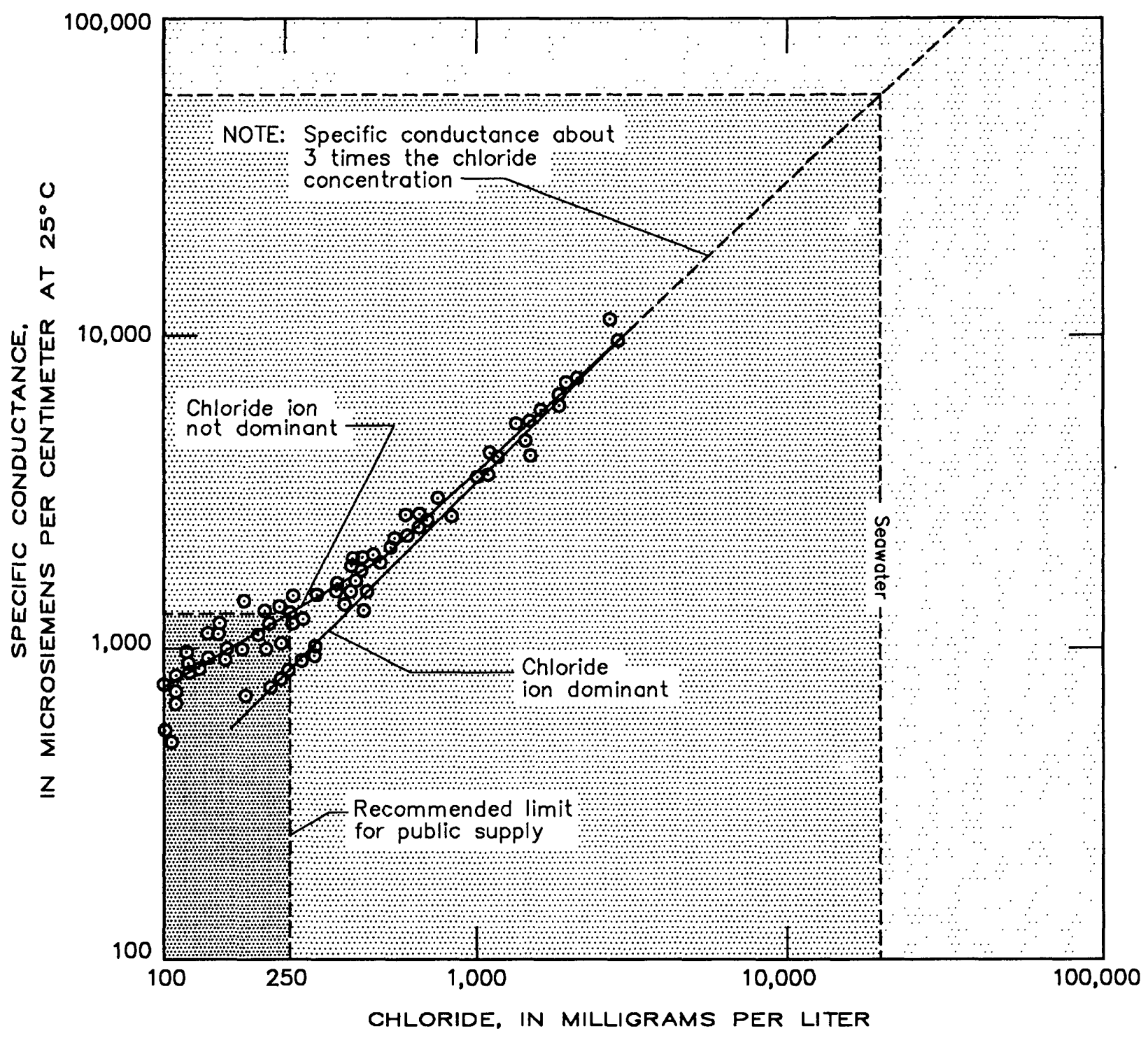

Figure 16.--Relation between chloride concentration and specific conductance.

GEOHYDROLOGY OF THE SURFICIAL AQUIFER SYSTEM

\section{Hydrogeologic Framework}

The surficial aquifer system consists of sediments of Pliocene age and younger that overlie the intermediate confining unit (Hawthorn Formation) of the Floridan aquifer system. In eastern Indian River County, the surficial aquifer system consists of a relatively thin, indurated carbonate unit, and an overlying relatively thick unit of unconsolidated clastic deposits. The surficial aquifer system generally is unconfined, but in places, may be semiconfined or confined where beds of low permeability are present. In this report, the surficial aquifer system is divided into two hydrogeologic units (table 1). The carbonate rock unit (Tamiami Formation) is termed the "shallow rock zone" and the unconsolidated clastic unit (combined Holocene deposits, Fort Thompson and Anastasia Formation) is termed the "clastic zone." 


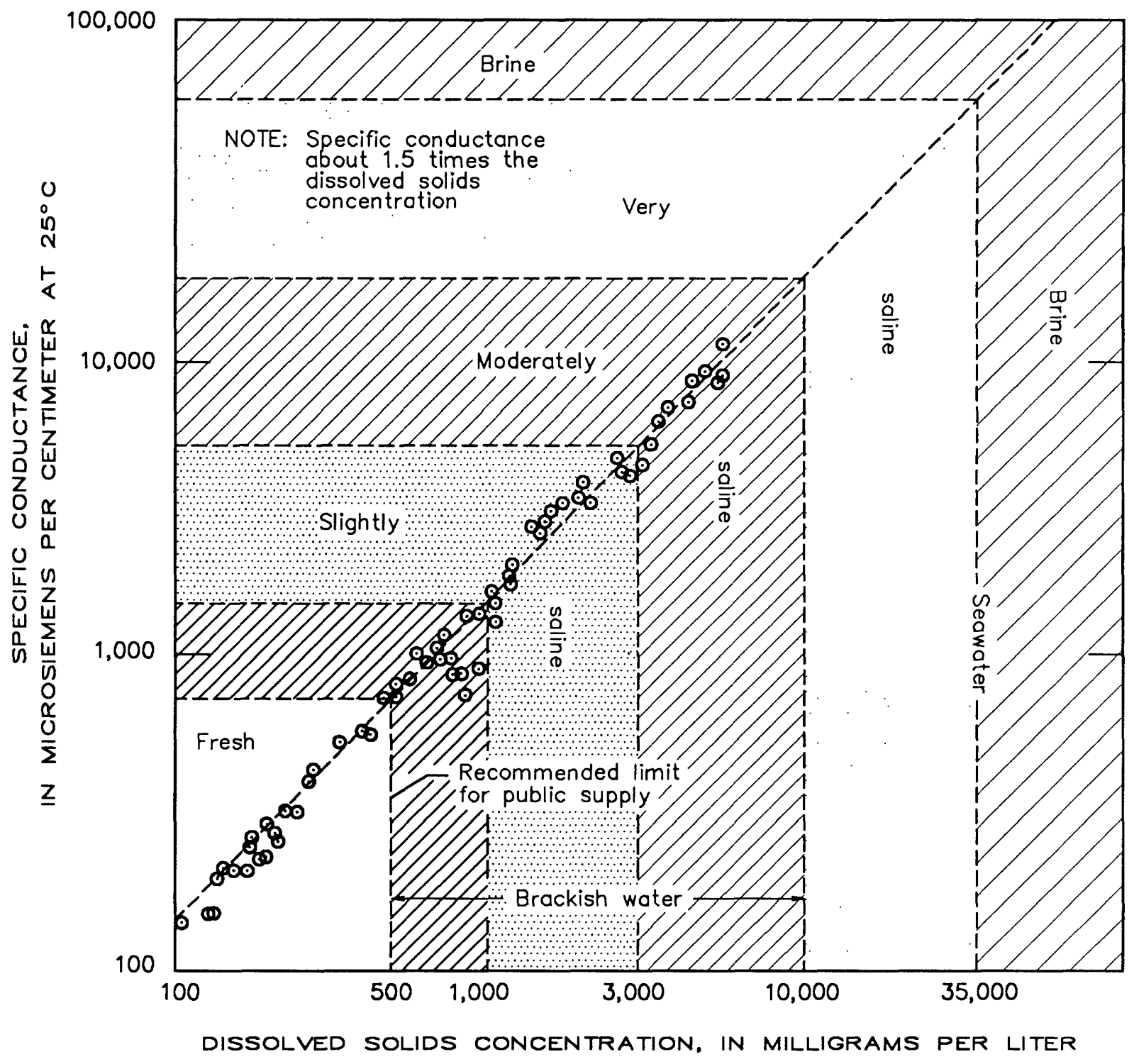

Figure 17.--Relation between specific conductonce and dissolved-solids concentration, and the classification of salinity of water.

In eastern Indian River County, the thickness of the surficial aquifer system is related to the topography, so the system is thickest beneath the higher areas such as the Ten-Mile Ridge and the Atlantic Coastal Ridge. The system ranges in thickness from about 100 to 200 feet (fig. 18) and thickens southward to its maximum south of State Road 60. The hydrogeologic sections in figure 10 indicate the extent and thickness of the surficial aquifer system in eastern Indian River County.

The Tamiami Formation is composed of interbedded limestone, coquina, and sand and clay of Pliocene age. The formation, as much as 60 feet thick (fig. 19), overlies the Hawthorn Formation and is confined to the eastern part of the county. Its maximum thickness coincides with the Atlantic Coastal Ridge north of Vero Beach--thickness decreases east and west of the ridge. West of the Ten-Mile Ridge, the Tamiami grades into a "gray sand zone" that consists of gray sand and shell interbedded with clayey sands. The Tamiami Formation is often called "hardrock" by local well drillers. 


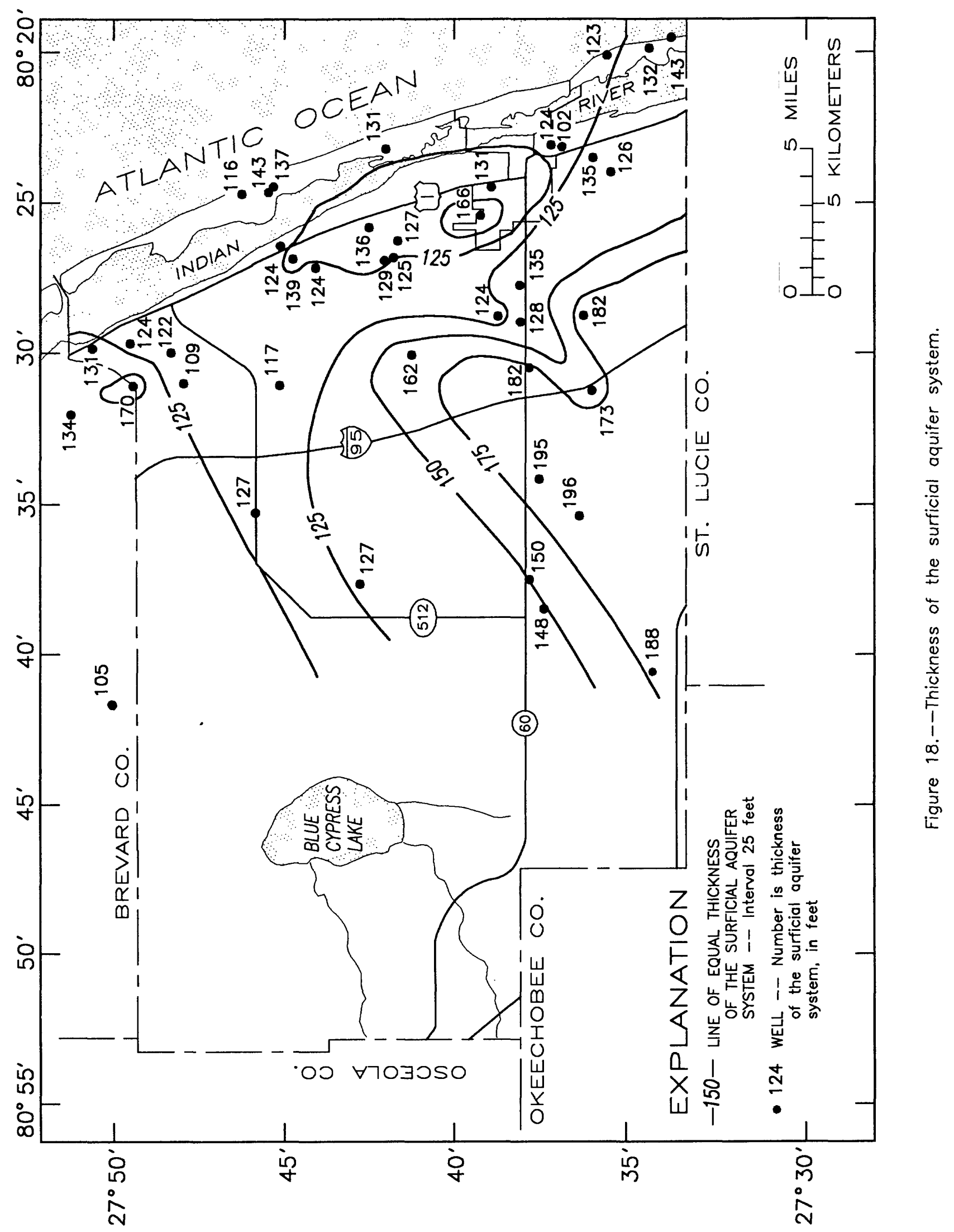




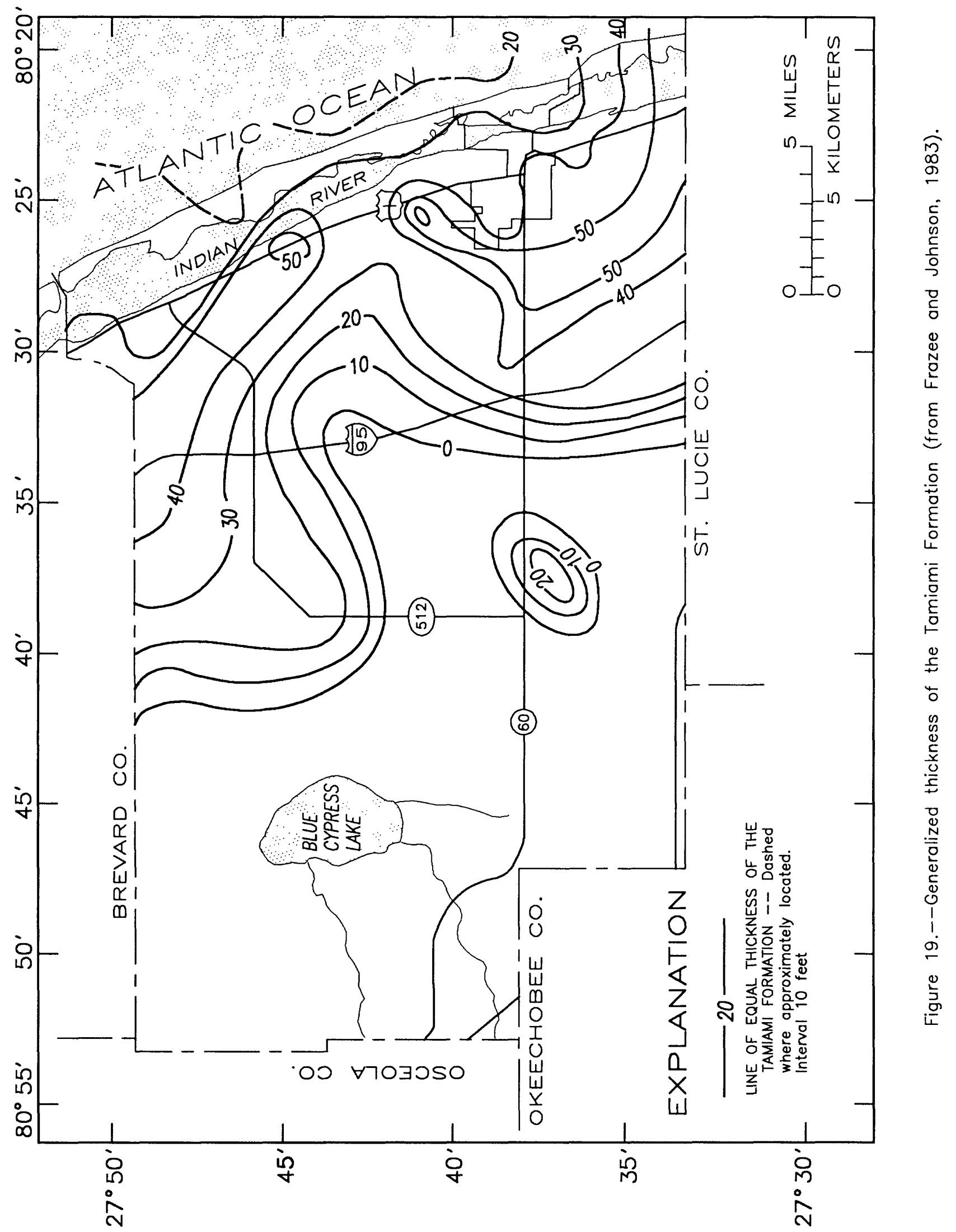


The Anastasia Formation consists primarily of shellbeds of Pleistocene age that contain varying amounts of quartz sand, silt, and organic material. The shellbeds range from uncemented to a moderately hard coquina. The Anastasia Formation generally underlies the Barrier Islands and extends inland about 3 to 10 miles to the vicinity of the Ten-Mile Ridge. There, the composition of the Anastasia Formation changes from mostly shell to sand (Bermes, 1958; Crain and others, 1975). West of the Ten-Mile Ridge, the Fort Thompson Formation is equivalent to the Anastasia Formation and consists of less cemented coquina lenses and progressively greater percentages of sand and some very sandy limestone beds (Bermes, 1958).

The Anastasia Formation, and (or) the Fort Thompson Formation generally is covered by thin Holocene sands, silts, and clay. The combined thickness of Holocene and Anastasia or Fort Thompson deposits ranges from about 100 to 200 feet.

\section{Hydraulic Properties}

The hydraulic properties of the surficial aquifer system in eastern Indian River County vary considerably from place to place depending on characteristics such as grain size, sorting, packing, and cementation. These properties are reflected in values of transmissivity, storage, hydraulic conductivity and specific capacity that indicate the ability of an aquifer to yield water to wells. Transmissivity is a measure of the rate at which water moves through a unit width of an aquifer under a unit hydraulic gradient. The storage coefficient is the volume of water an aquifer releases from or takes into storage per unit surface area of the aquifer per unit change in head. Leakance is the ratio of the vertical hydraulic conductivity and the thickness of the confining unit and is a measure of the ability of confining units to leak water to adjacent aquifers. Hydraulic conductivity is defined as the rate of water flow through a unit cross section of an aquifer under a unit hydraulic gradient. Generally, the larger the value for transmissivity and hydraulic conductivity, the more productive the aquifer.

Specific capacity is defined as the well discharge per unit of drawdown. Specific capacities of wells completed in the surficial aquifer system in eastern Indian River County range from 21 to 70 ( $\mathrm{gal} / \mathrm{min}$ )/ft (fig. 20). In the Vero Beach well field, specific capacities range from 9 to 36 (gal/min)/ft (fig. 21). Specific capacities tend to be highest in the areas south of Main Canal and west of the airstrip but decrease to the east and southwest.

Values of transmissivity, storage coefficient, and hydraulic conductivity for the surficial aquifer system at several locations are given in table 2. Transmissivities range from $1,500 \mathrm{ft}^{2} / \mathrm{d}$ at Winter Beach to 11,000 $\mathrm{ft}^{2} / \mathrm{d}$ at Sebastian Highlands where the aquifer is mostly shell deposits. At Hobart Park, the aquifer also contains shell deposits, and the transmissivity is $7,900 \mathrm{ft}^{2} / \mathrm{d}$. Transmissivity values tend to be lower in the shallow rock zone than in the clastic zone. At Vero Beach, where wells penetrate both zones, transmissivities range from 2,400 to $6,300 \mathrm{ft}^{2} / \mathrm{d}$. 


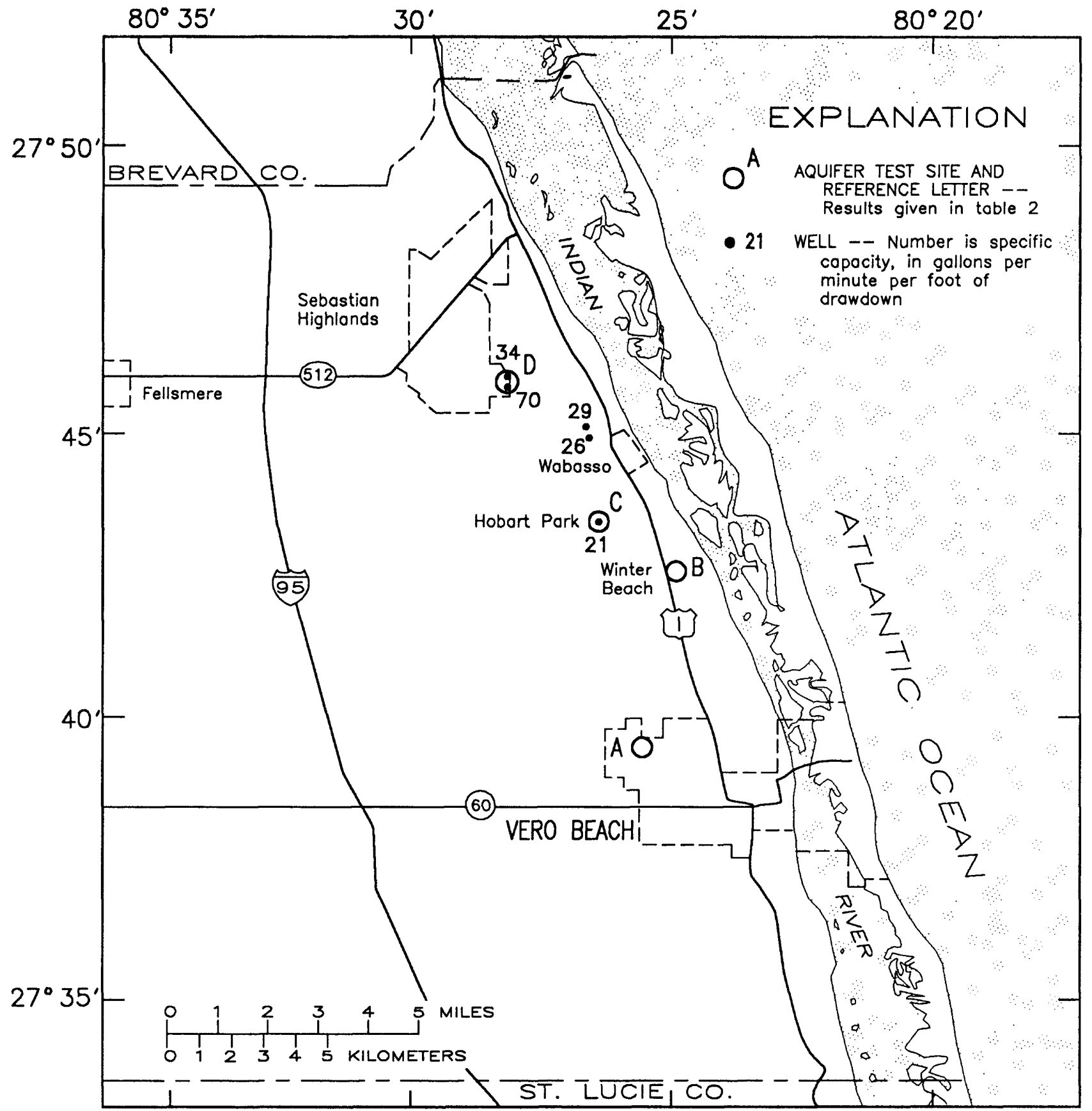

Figure 20.--Specific capacity of wells completed in the surficial aquifer system and location of aquifer test sites in eastern Indian River County. 


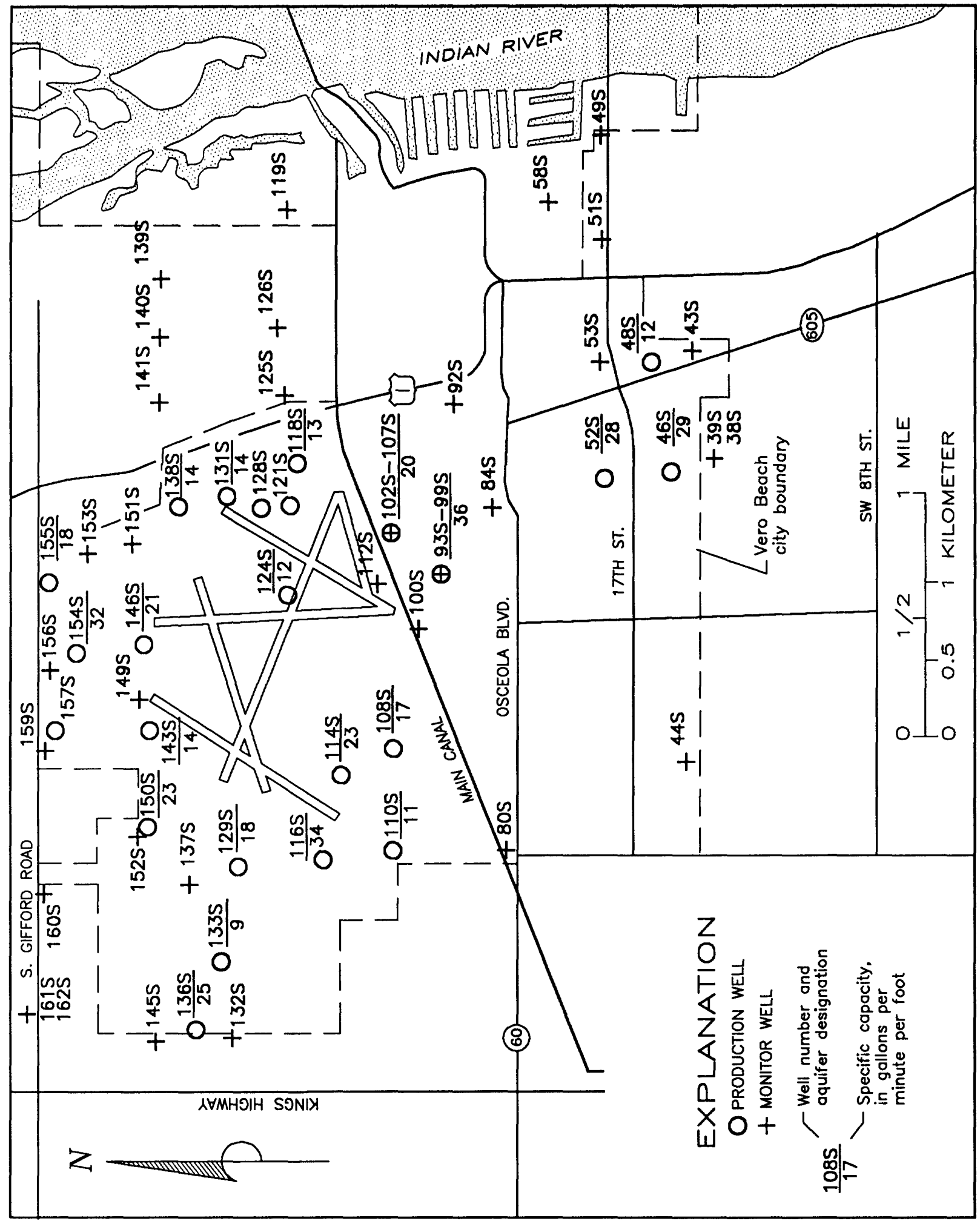

들 
Table 2.--Aquifer-test results for the surficial aquifer system at four sites in Indian River County

$$
\left[\mathrm{ft} \mathrm{t}^{2} / \mathrm{d}=\text { feet squared per day; } \mathrm{ft} / \mathrm{d}=\text { feet per day }\right]
$$

\begin{tabular}{|c|c|c|c|c|c|}
\hline $\begin{array}{l}\text { Reference } \\
\text { letter } \\
\text { (fig. 20) }\end{array}$ & $\begin{array}{c}\text { Site } \\
\text { location }\end{array}$ & $\begin{array}{l}\text { Transmis- } \\
\text { sivity (T) } \\
\left(\mathrm{ft}^{2} / \mathrm{d}\right)\end{array}$ & $\begin{array}{l}\text { Storage } \\
\text { coeffi- } \\
\text { cient (S) }\end{array}$ & $\begin{array}{c}\text { Hydraulic } \\
\text { conductivity } \\
\text { ft/d }\end{array}$ & $\begin{array}{l}\text { Source } \\
\text { of } \\
\text { data }^{2}\end{array}$ \\
\hline $\mathrm{A}$ & Vero Beach & $\begin{array}{c}2,400-6,300 \\
\ldots\end{array}$ & $\begin{array}{l}2.3 \times 10^{-4} \\
1.5 \times 10^{-1}\end{array}$ & $\begin{array}{c}33-80 \\
\ldots-\end{array}$ & 1 \\
\hline B & Winter Beach & $1,500-1,900$ & $1.9 \times 10_{-2}^{-8}$ & $40-48$ & 2 \\
\hline C & Hobart Park & 7,900 & $1.4 \times 10_{-4}^{-2}$ & 110 & 3 \\
\hline $\mathrm{D}$ & $\begin{array}{l}\text { Sebastian } \\
\text { Highlands }\end{array}$ & 11,000 & $1.0 \times 10^{-8}$ & 348 & 4 \\
\hline
\end{tabular}

\footnotetext{
${ }^{1}$ Hydraulic conductivity estimated from transmissivity and thickness of aquifer penetrated.

2Reference: (1) Gee and Jenson (1980).

(2) Estimated from the hydrograph of a cyclically pumped we11

(Brown, 1963) using a well at Winter Beach.

(3) Geraghty and Miller (1978).

(4) Geraghty and Miller (1981a).
}

Storage coefficients for the surficial aquifer system at four sites in Indian River County range from $1.0 \times 10^{-4}$ at Sebastian Highlands to 0.15 at Vero Beach (table 2). At most of the sites, the zones tested in the surficial aquifer system responded as a leaky artesian aquifer. At Vero Beach, the aquifer at one of two sites tested in the surficial aquifer system acted as an unconfined aquifer (storage coefficient is 0.15 ).

Hydraulic conductivities of the surficial aquifer system in Indian River County are generally about $40 \mathrm{ft} / \mathrm{d}$ (feet per day), but some values may exceed $350 \mathrm{ft} / \mathrm{d}$ where shell deposits are extensive.

\section{Description of We11s that Tap the System}

For this study, 336 wells in the surficial aquifer system were inventoried (see Supplementary Data I and fig. 2). These wells represent only a small number of the surficial wells that exist in Indian River County. Uninventoried domestic and irrigation wells probably number in the thousands.

We11s that penetrate the clastic zone range from 35 to 90 feet in depth. Well casings generally extend to the top of a producing zone--the remaining depth of hole is commonly screened. Large-yield wells often tap both the clastic zone and the underlying shallow rock zone of the surficial aquifer system. The shallow rock zone is usually left as open hole in wells that penetrate both zones. 
The location of production and monitor wells in the Vero Beach well field is shown in figure 21. Supply wells in the Vero Beach well field are 80 to 140 feet deep, have 40 to 65 feet of casing, and are typically completed as open-hole. Yields of wells in the Vero Beach well field range from 250 to $1,200 \mathrm{gal} / \mathrm{min}$. The larger yields are from wells that are deep enough to tap both the clastic and the shallow rock zones, and where the surficial aquifer system is thickest. The lowest yields in the county (less than $10 \mathrm{gal} / \mathrm{min}$ ) occur in marsh areas in the central part of the county.

\section{Water Levels}

Water levels in the surficial aquifer system in the eastern part of the county fluctuate in response to seasonal changes in precipitation, evapotranspiration, and pumping. Water levels also may fluctuate in response to manipulation of flows in these drainage network in the county.

Water levels have been monitored in several observation wells in the surficial aquifer system (fig. 22). Hydrographs showing long-term variations in water levels in the wells are shown in figure 24.

In the southwestern part of the county, at the western edge of the Pamlico terrace (fig. 4), water levels are near land surface. The land surface altitude is about 30 feet at well $134 \mathrm{~S}$ (fig. 22) and during wet periods water levels may rise above the land surface. Water levels in this well fluctuate between 25 and 31 feet altitude but average about 28 feet (fig. 23).

Hydrographs of daily maximum water levels in wells $239 \mathrm{~S}, 316 \mathrm{~S}$, and $217 \mathrm{~S}$ are shown in figures 23 and 24. At well 239S near Fellsmere (fig. 22) the land surface altitude is about 27 feet. Water levels in that well fluctuate by as much as 2 feet monthly and declined from an altitude of about 26 feet to about 23 feet between September 1982 and May 1983. During the interval between September 1984 and May 1985, levels remained close to an altitude of 25 feet.

At we11 316s in Roseland (fig. 22), water levels declined from above 17 to 15 feet altitude between September 1982 and July 1983. Since April 1984, the altitudes of water levels in this well have been above 14.5 feet. At Wabasso School (well 217S, figs. 22 and 24), the altitude of the water level declined from about 9 feet in May 1983 to near 6.5 feet in September 1984. Between March and May 1985, water-level altitudes fluctuated from below 7 to above 11 feet, and averaged 9 feet. The wells at Roseland and Wabasso School are located just west and east of the Atlantic Coastal Ridge where land surface altitudes are 19 and 12 feet, respectively.

The effect of nearby pumping on water levels in the surficial aquifer system was observed at well 39S (see fig. 22 for location). Water-level altitudes in well $39 \mathrm{~S}$ averaged about 16 feet between May 1983 and Apri1 1984, 14 feet between May and November 1984, and approximately 7.5 feet during January through March 1985. In April 1985, water levels had declined to an altitude of 4 feet. The 10-foot decline in the water leve1 in this well coincided with the startup of a nearby well at Vero Beach (well $46 \mathrm{~S}$ ). 


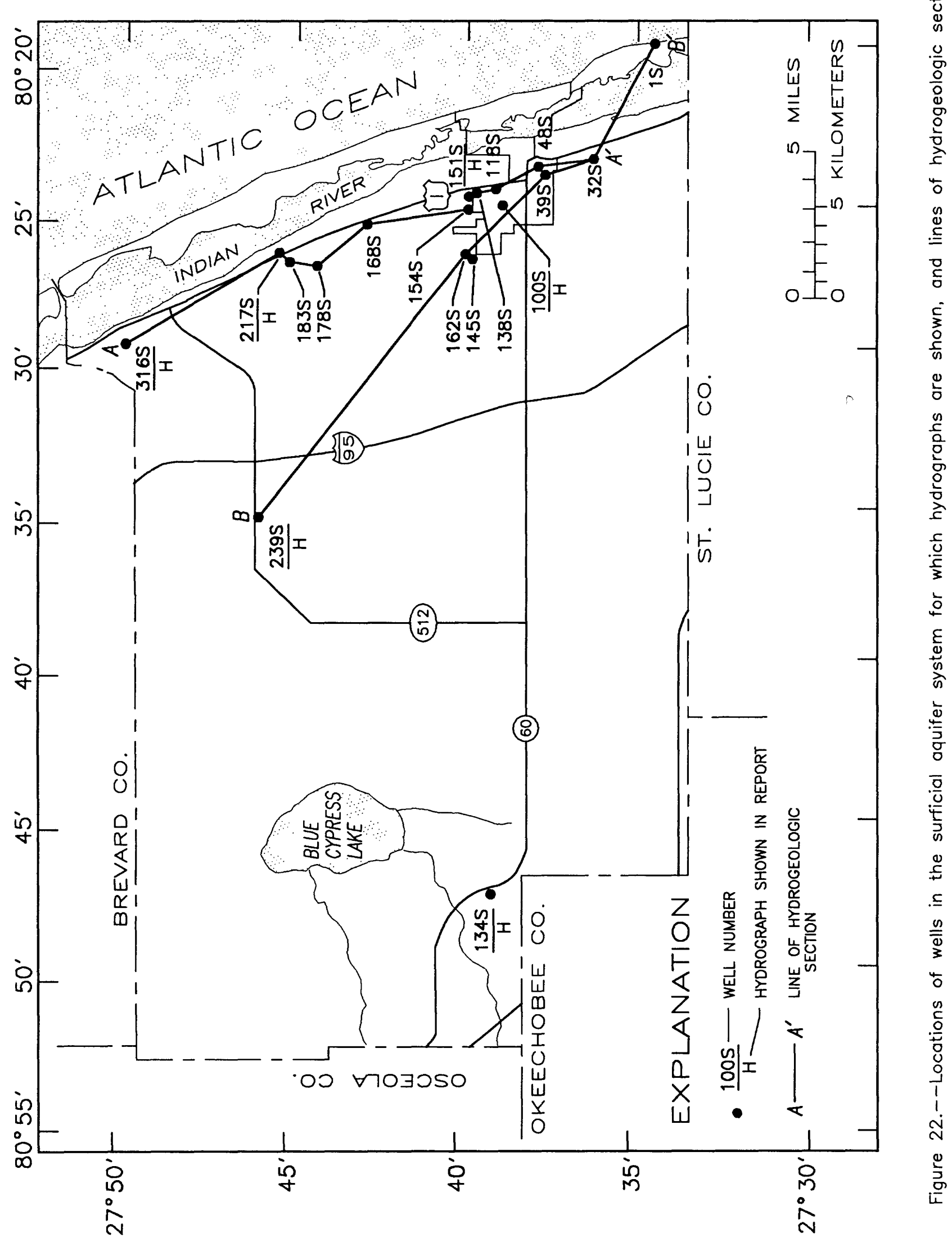




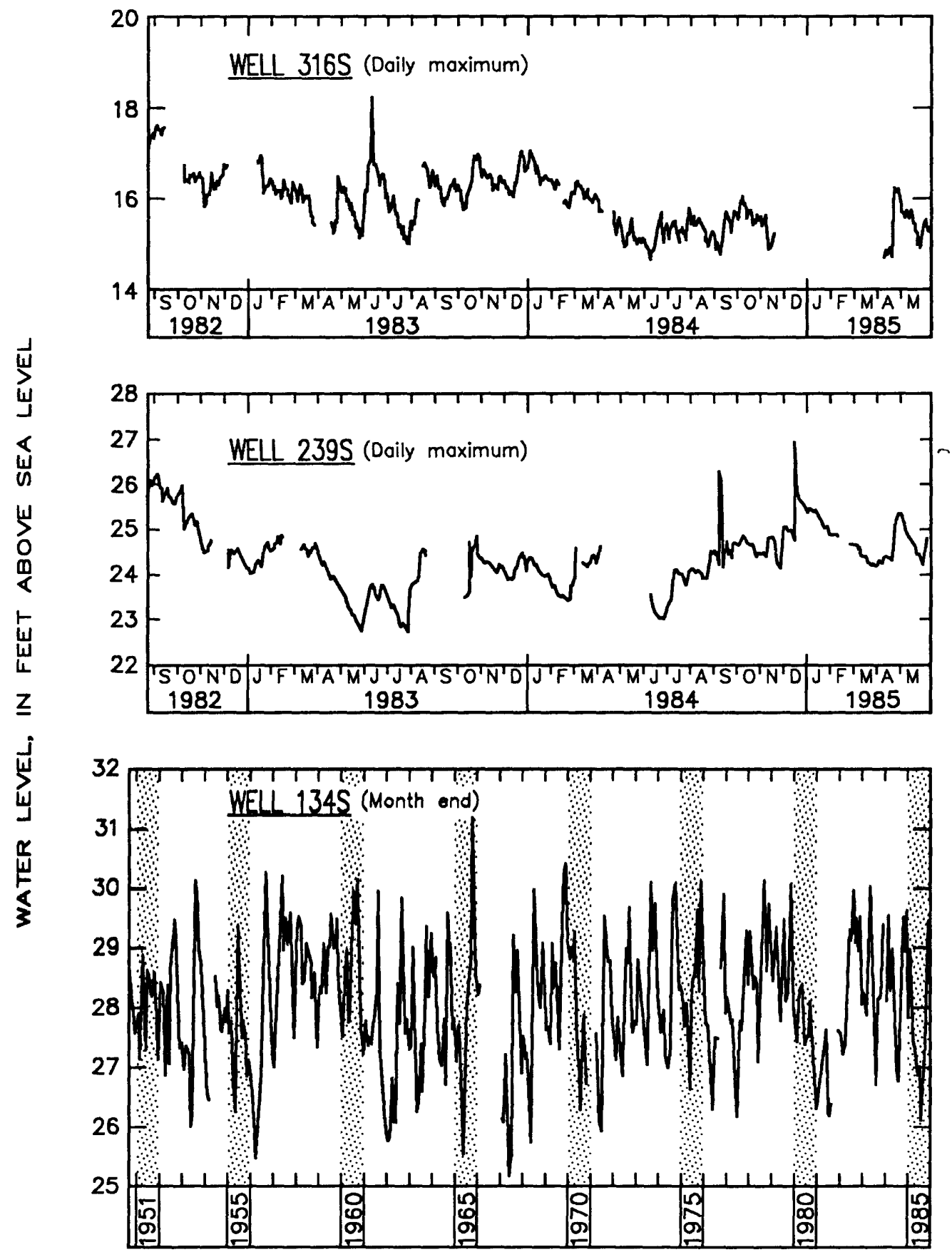

Figure 23.--Water level in wells 316S, 239S, and 134S. 

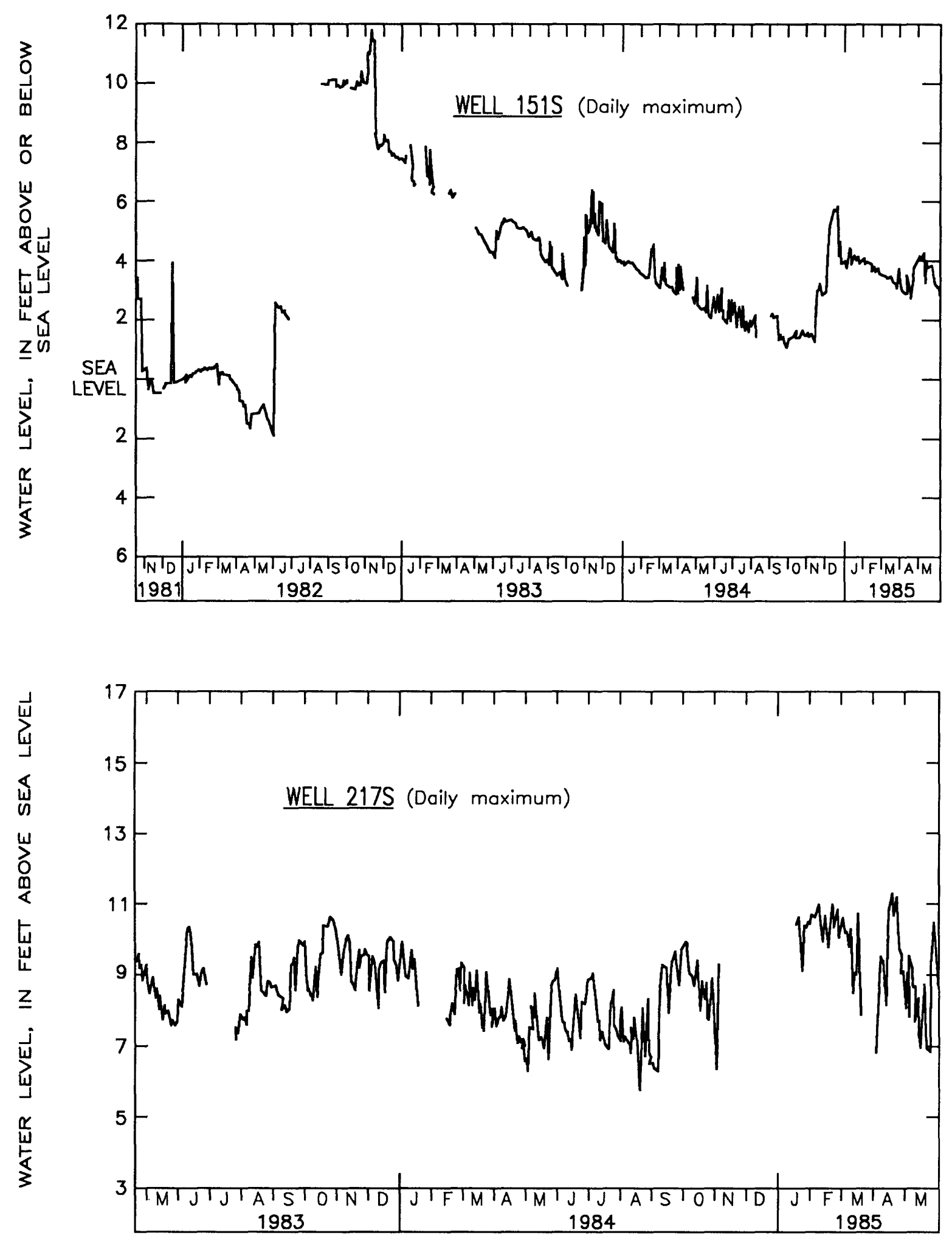

Figure 24.--Water level in wells $151 \mathrm{~S}$ and $217 \mathrm{~S}$. 


\section{Water Levels in the Vero Beach Well Field}

Water levels in the Vero Beach well field during May 1981 (an unusually dry year) and May 1984 (a year of about average rainfal1) are shown in figures 25 and 26. Water levels were measured in monitor and production wells, when pumps were operating, and therefore illustrate the general pattern of the cone of depression caused by well-field pumping. In May 1981, water levels were as low as 39 feet below sea level (fig. 25). Water levels were lowest east and north of the airstrip. In May 1984 water levels at pumping centers were as much as 28 feet higher than in May 1981. Water levels continued to be lowest east and north of the airstrip. The difference in water levels between the first half of 1981 and 1984 is clearly shown in the hydrograph of well 121s in the Vero Beach well field (fig. 27). In 1981, water levels at production well 121s reached more than 37 feet below sea level, but rebounded to near sea level during periods of average rainfall (see rainfall graph in fig. 30). Part of the rise in water level is probably caused by a change in the pattern of pumping in the well field.

Some observation wells, such as $145 \mathrm{~S}$ and $100 \mathrm{~s}$ in the Vero Beach we11 field, are apparently little affected by pumping. Monitor well $145 \mathrm{~S}$ is west of the well field and monitor well $100 \mathrm{~s}$ is located adjacent to Main Canal (fig. 22). Water levels in monitor well $145 \mathrm{~S}$ were lowest during the summer of 1981 and spring of 1985 (fig. 30). Both time intervals coincide with much below-average rainfall periods. Levels in 145S remained high in 1982 when rainfall was above average.

Yields of many wells in the Vero Beach well field decreased in 1981 due to the large drawdowns in the surficial aquifer system caused by long-term continuous pumping. The problem was alleviated by implementing a well-field management program that involved alternating withdrawals between sets of wells spaced far enough apart so as to minimize interfering drawdowns. In addition, a few wells were deepened to penetrate the shallow rock zone, and several wells were installed to replace wells previously abandoned because of low yield. The hydrograph of observation well 151s (fig. 24) illustrates the effect of nearby pumping from production wells prior to mid-1982, and the effect of well field expansion and management since mid-1982.

Figure 28 shows the average monthly daily pumpage for the Vero Beach well field from 1975 to 1985 . Pumpage approximately doubled during the 10 -year period from 1975 to 1985 and peaked to about $9.5 \mathrm{Mgal} / \mathrm{d}$ in the spring during the 1981 drought. Coinciding with the increase in pumpage, however, water levels have declined in the vicinity of the Vero Beach well field. A recent downward trend is shown by the hydrograph of well 151s also in the Vero Beach well field (fig. 24). Water levels reached a low of 5 feet below sea level in June 1982 but rebounded to an altitude of 9.5 feet in September 1982. Since December 1982 water levels have declined and by October 1984 were 1 foot below sea level. A comparison of water levels in the surficial aquifer in the vicinity of the Vero Beach well field in April 22, 1971, (Crain and others, 1975, fig. 28, p. 55) with water levels in May 1984 (fig. 26), indicates a decline of about 15 to 19 feet. 


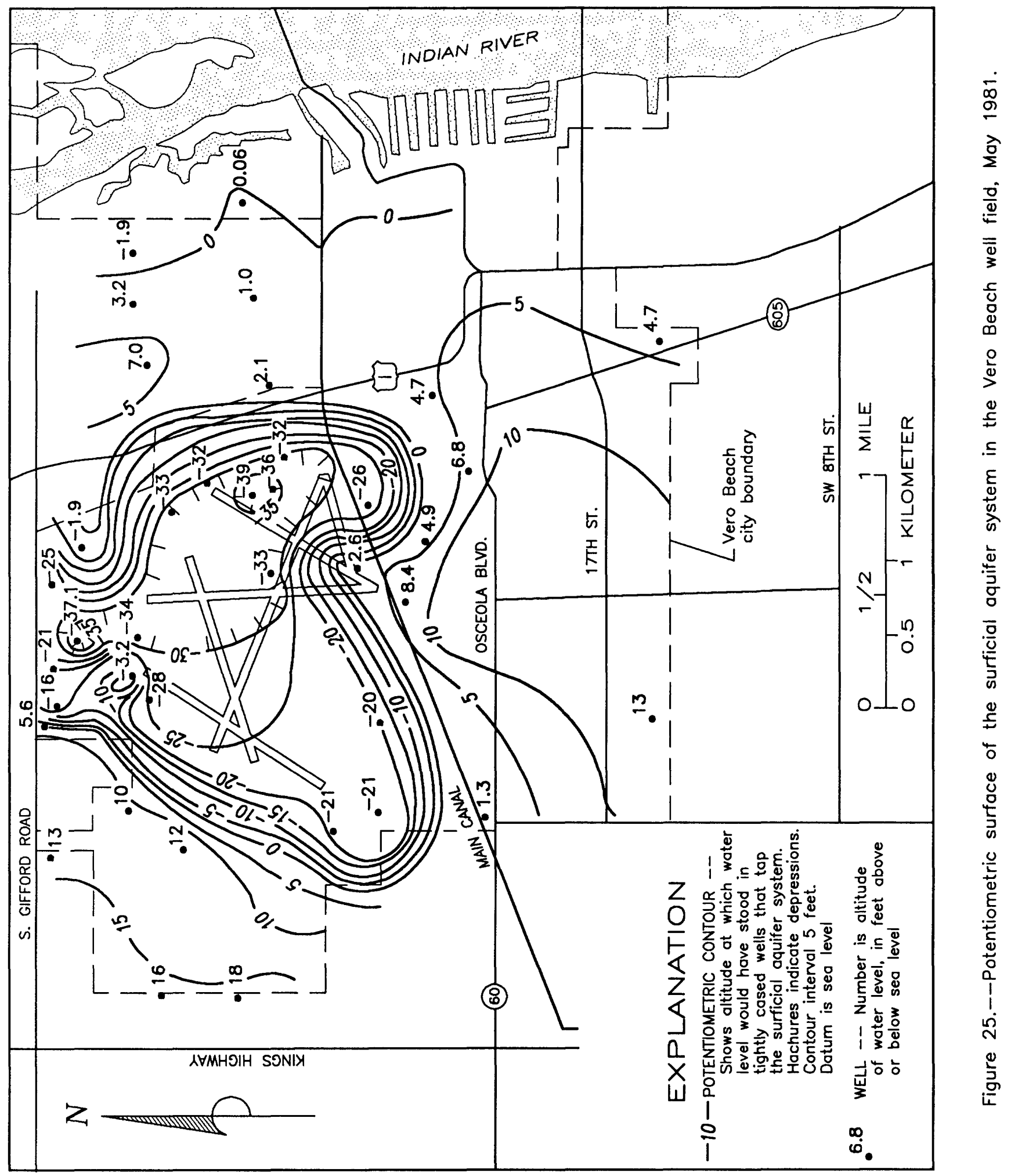




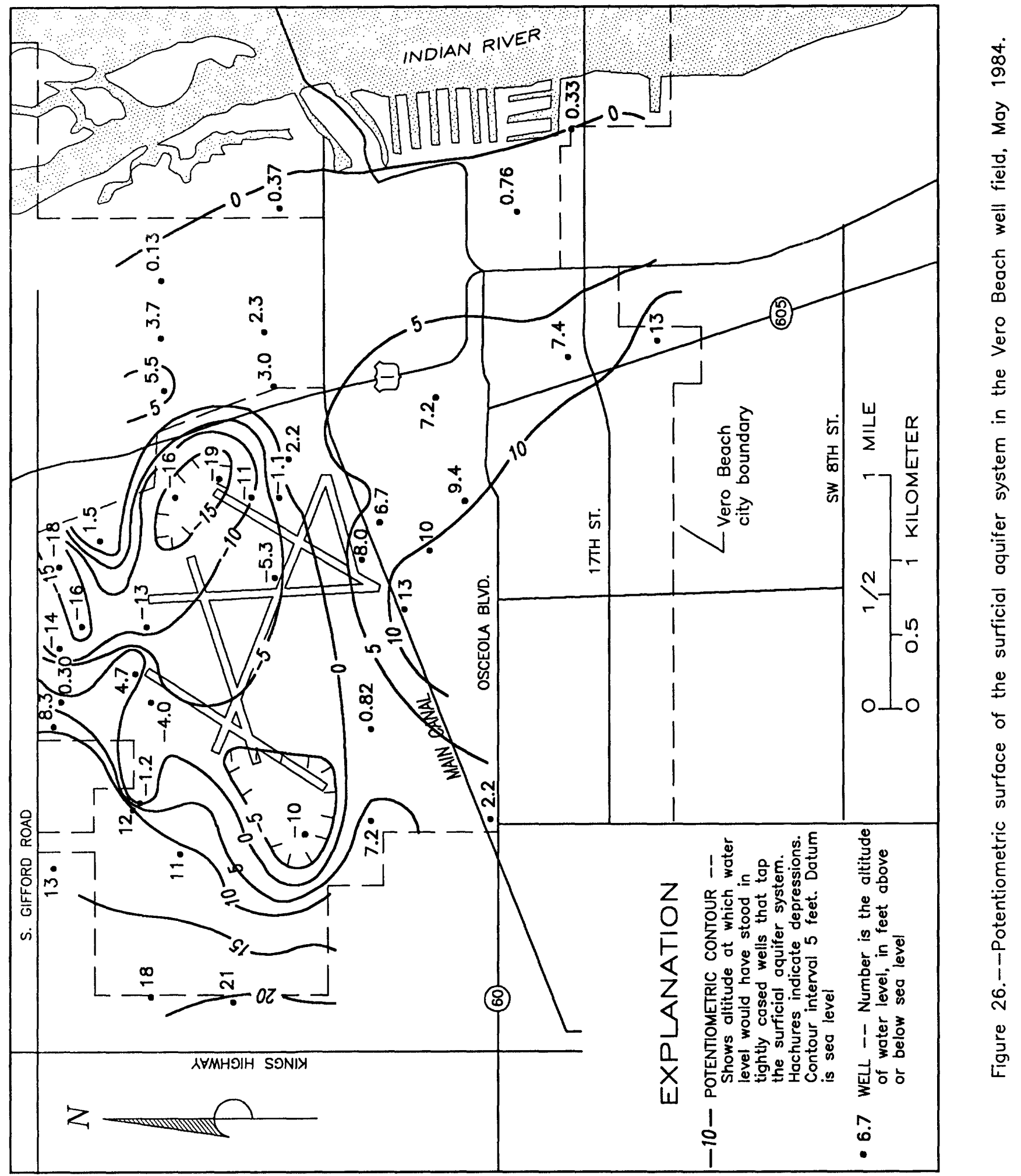




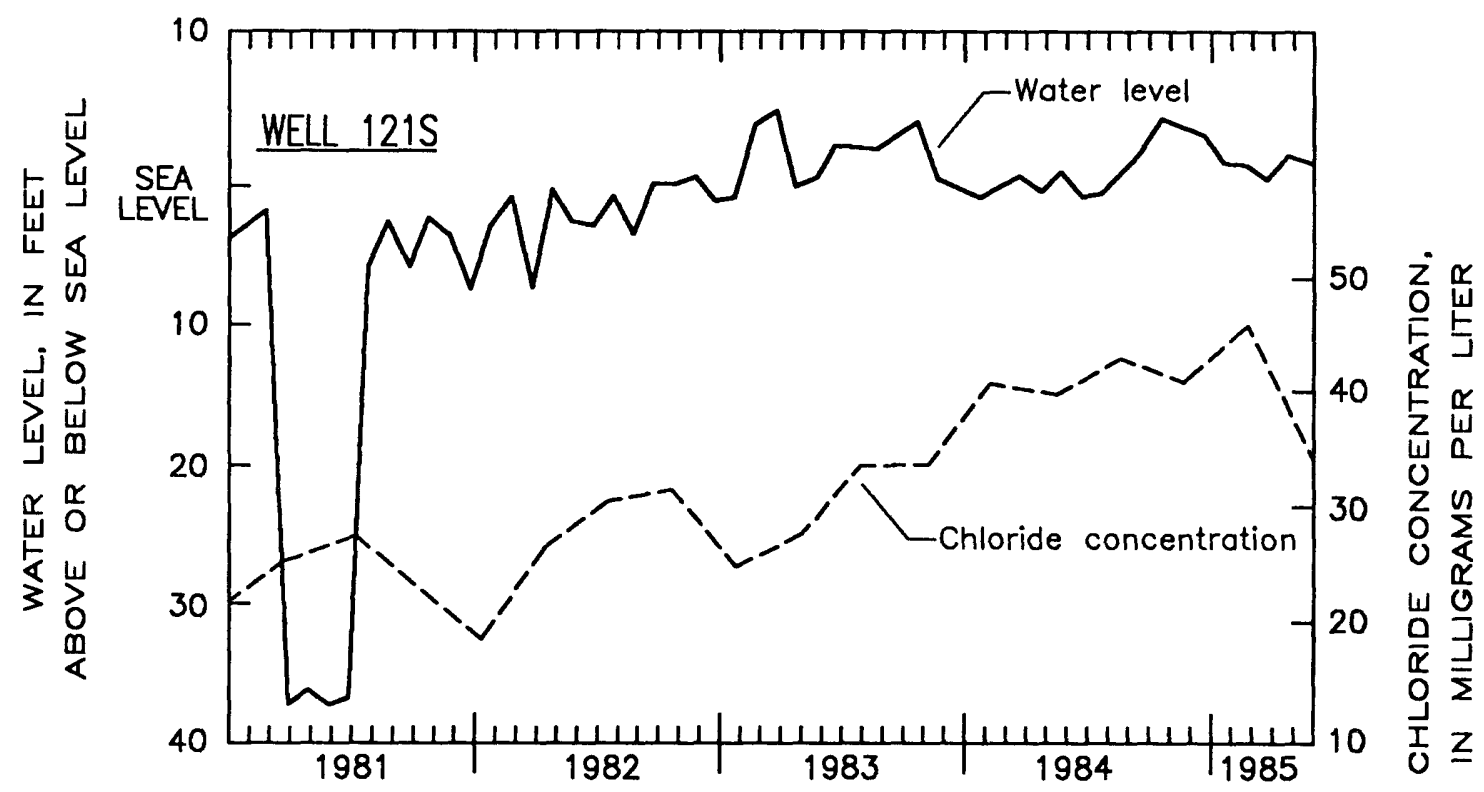

Figure 27.--Water level and chloride concentration of water in well $121 \mathrm{~S}$ in the Vero Beach well field, 1981-85.

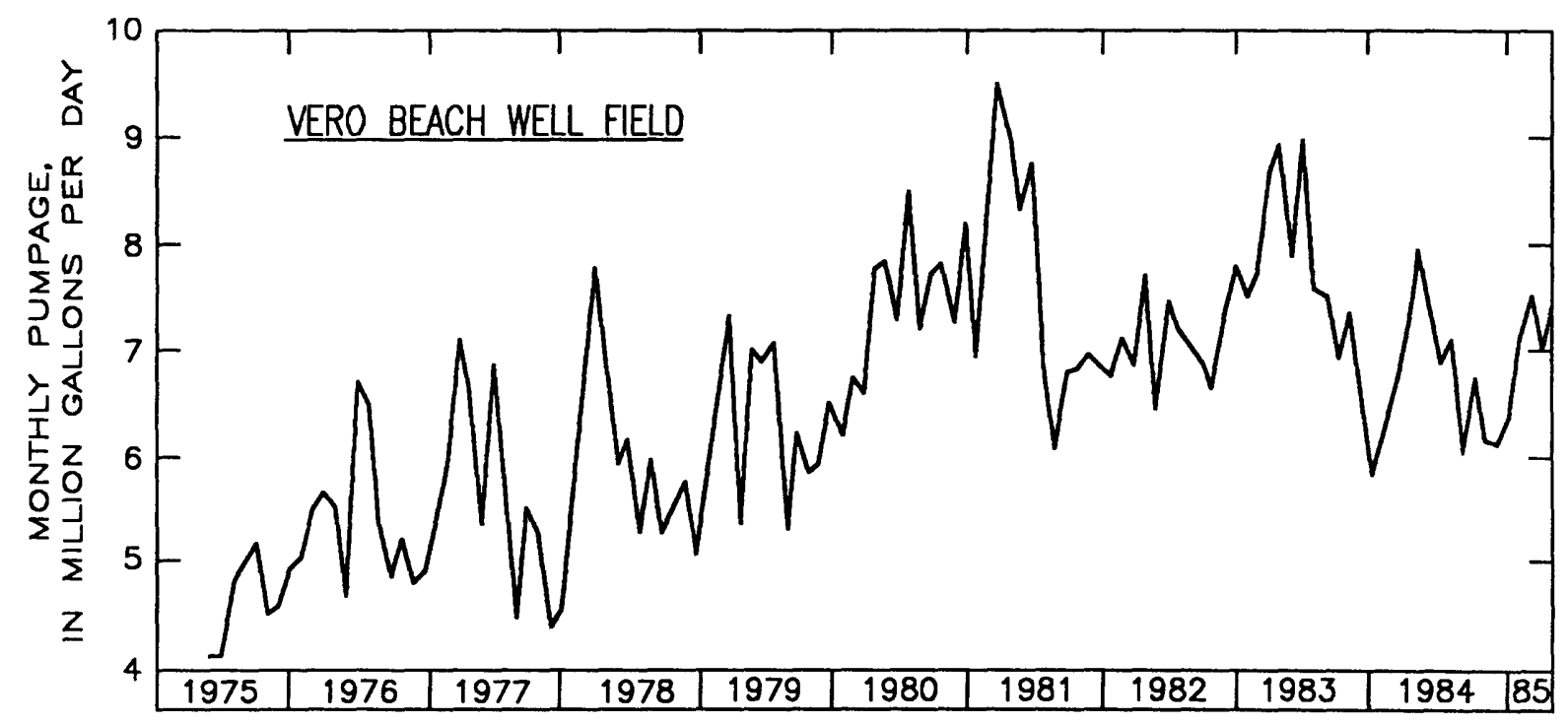

Figure 28.--Monthly pumpage from the Vero Beoch well field, 1975-85. 


\section{Recharge and Discharge in the System}

The surficial aquifer system in Indian River County is recharged mostly by infiltration of rainfall and by some downward percolation of irrigation water. The aquifer system receives little recharge from the underlying Floridan aquifer system because a thick confining unit of low permeability strata (the Hawthorn Formation) effectively separates the surficial and Floridan aquifer systems. Discharge from the surficial system occurs as seepage to the ocean, lakes, rivers, and canals, evapotranspiration, and withdrawals from wells.

Some recharge to the surficial aquifer system may occur from the canal system. For example, maximum stage fluctuations in Main Canal and waterlevel fluctuations of monitor well loos (adjacent to Main Canal) are strikingly similar (fig. 29). When maximum stage is greater than the water level in well 100S, such as in the spring of 1981-82, water in Main Canal probably recharged the surficial aquifer.

The water level in the surficial aquifer system rises and declines during wet and dry periods in response to recharge and discharge. The hydrograph of well 145S (fig. 30) illustrates the relation between monthly rainfall at Vero Beach and water levels in the well. The water level in wel1 $145 \mathrm{~S}$ rose 5.7 feet in response to the rainfall of 16 inches in August 1981 and an attendant reduction in pumpage.

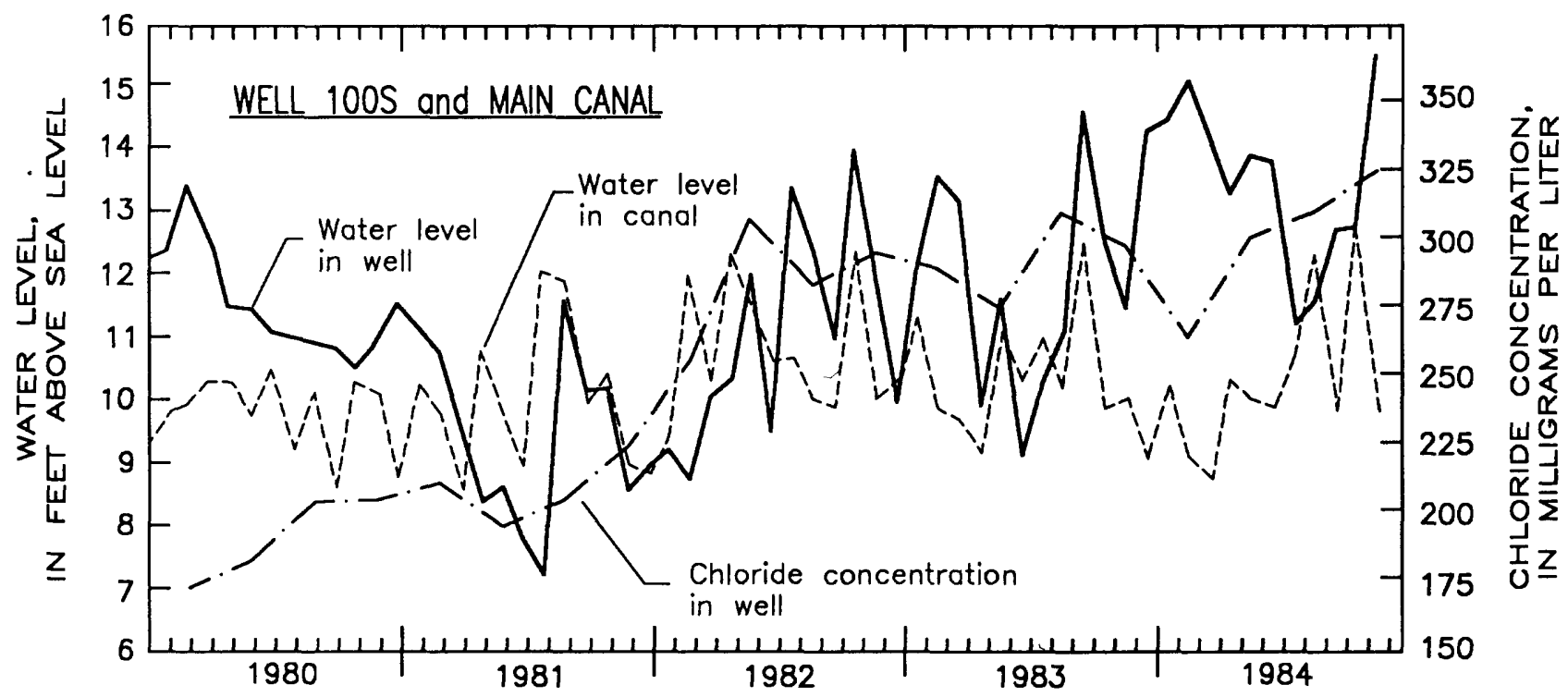

Figure 29.--Water level and chloride concentration of water in well 100S, and stage of Main Canal, 1980-84. 

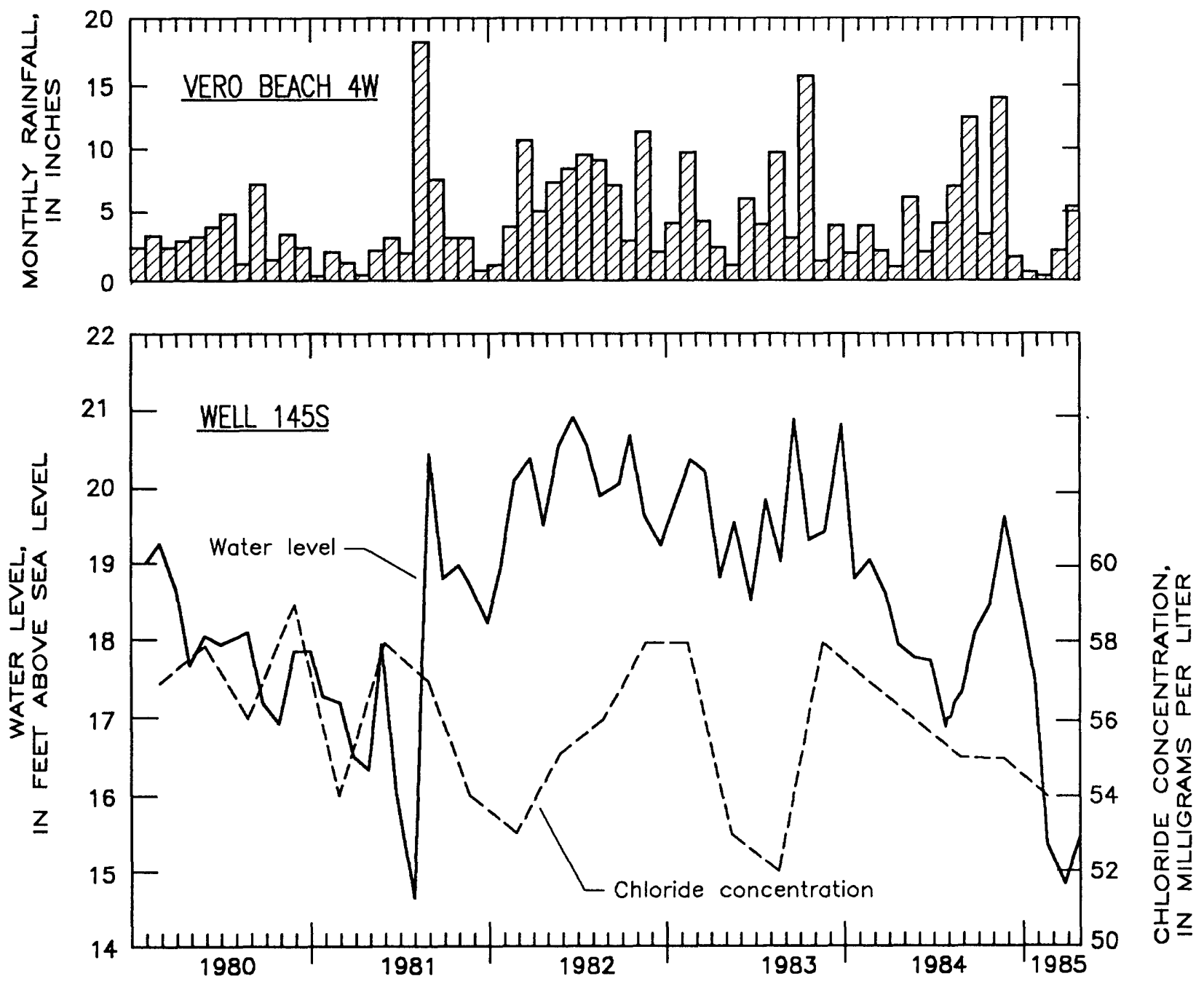

Figure 30.--Water level and chloride concentrotion of water in well 145S, and monthly roinfall ot Vero Beoch, 1980-85.

In places, head differences in the clastic and shallow rock zones allow ground-water movement from one zone to the other. To observe the headdifference relations, observation wells were installed in both the shallow rock zone and the clastic zone at several sites throughout the county. The well locations, well numbers, and selected water-level data are given in table 3 and figures 1 and 21. Comparison of water levels in the shallow rock and clastic zones at Vero Beach Elementary Schoo1 (39S, 38S), South Gifford Road (162S, 161S), Wabasso (178S, 177S), and Roseland (316S, 317S) show 1ittle head difference (table 3). However, at the South Canal (31S, 32S), Winter Beach (168S, 167S), Wabasso School (217S, 216S), and Fellsmere (239S, 240S) the heads in the zones differ. This difference in head and location of wells can be used to define a pattern of recharge and discharge. West of the Atlantic Coastal Ridge, in wells 239S, 240S, 168S, and 167S, water levels are higher in the clastic zone than in the shallow rock zone; therefore, in this area, the clastic zone recharges the underlying shallow 
Table 3.--Water levels in wells in the clastic zone and shallow rock zone

\begin{tabular}{|c|c|c|c|c|c|c|}
\hline \multirow{2}{*}{$\begin{array}{l}\text { Well } \\
\text { No. }\end{array}$} & \multirow[b]{2}{*}{ Location } & \multirow[b]{2}{*}{ Aquifer } & \multicolumn{4}{|c|}{ Water level, in feet above sea level } \\
\hline & & & Feb-Mar 1983 & Dec 1983 & April 1984 & March 1985 \\
\hline $\begin{array}{l}31 S \\
32 S\end{array}$ & South Canal & $\begin{array}{l}\text { Shallow rock zone } \\
\text { Clastic zone }\end{array}$ & $\begin{array}{l}9.8 \\
7.8\end{array}$ & $\begin{array}{l}9.6 \\
6.7\end{array}$ & $\begin{array}{l}8.1 \\
6.1\end{array}$ & $\begin{array}{l}6.6 \\
5.4\end{array}$ \\
\hline $\begin{array}{l}39 S \\
38 S\end{array}$ & $\begin{array}{l}\text { Vero Beach } \\
\text { Elementary School }\end{array}$ & $\begin{array}{l}\text { Shallow rock zone } \\
\text { Clastic zone }\end{array}$ & $\begin{array}{l}19.1 \\
19.2\end{array}$ & $\begin{array}{l}17.0 \\
17.6\end{array}$ & $\begin{array}{l}18.3 \\
18.1\end{array}$ & $\begin{array}{l}11.1 \\
10.9\end{array}$ \\
\hline $\begin{array}{l}162 S \\
161 S\end{array}$ & South Gifford & $\begin{array}{l}\text { Shallow rock zone } \\
\text { Clastic zone }\end{array}$ & $\begin{array}{l}19.9 \\
20.1\end{array}$ & $\begin{array}{l}17.0 \\
17.3\end{array}$ & $\begin{array}{l}16.2 \\
16.7\end{array}$ & $\begin{array}{l}14.4 \\
15.1\end{array}$ \\
\hline $\begin{array}{l}168 \mathrm{~S} \\
167 \mathrm{~S}\end{array}$ & Winter Beach & $\begin{array}{l}\text { Shallow rock zone } \\
\text { Clastic zone }\end{array}$ & $\begin{array}{l}16.4 \\
18.1\end{array}$ & $\begin{array}{l}14.7 \\
16.1\end{array}$ & $\begin{array}{l}14.8 \\
17.0\end{array}$ & $\begin{array}{l}13.8 \\
15.3\end{array}$ \\
\hline $\begin{array}{l}178 \mathrm{~S} \\
177 \mathrm{~S}\end{array}$ & Wabasso & $\begin{array}{l}\text { Shallow rock zone } \\
\text { Clastic zone }\end{array}$ & $\begin{array}{l}18.2 \\
19.9\end{array}$ & $\begin{array}{l}16.5 \\
16.7\end{array}$ & $\begin{array}{l}16.7 \\
17.3\end{array}$ & $\begin{array}{l}15.0 \\
15.2\end{array}$ \\
\hline $\begin{array}{l}217 S \\
216 S\end{array}$ & Wabasso School & $\begin{array}{l}\text { Shallow rock zone } \\
\text { Clastic zone }\end{array}$ & $\begin{array}{l}13.6 \\
11.7\end{array}$ & $\begin{array}{l}11.7 \\
10.6\end{array}$ & $\begin{array}{l}11.7 \\
10.6\end{array}$ & $\begin{array}{l}10.8 \\
10.2\end{array}$ \\
\hline $\begin{array}{l}239 S \\
240 S\end{array}$ & Fellsmere & $\begin{array}{l}\text { Shallow rock zone } \\
\text { Clastic zone }\end{array}$ & $\begin{array}{c}25.6 \\
--\end{array}$ & $\begin{array}{l}24.1 \\
24.7\end{array}$ & $\begin{array}{l}24.9 \\
25.9\end{array}$ & $\begin{array}{l}23.6 \\
24.3\end{array}$ \\
\hline $\begin{array}{l}316 \mathrm{~S} \\
317 \mathrm{~S} \\
\end{array}$ & Roseland & $\begin{array}{l}\text { Shallow rock zone } \\
\text { Clastic zone }\end{array}$ & $\begin{array}{l}17.9 \\
18.3 \\
\end{array}$ & $\begin{array}{l}16.8 \\
16.8 \\
\end{array}$ & $\begin{array}{l}16.7 \\
17.4 \\
\end{array}$ & $\begin{array}{l}16.6 \\
16.0 \\
\end{array}$ \\
\hline
\end{tabular}

rock zone. East of the ridge, in we1ls $31 \mathrm{~s}, 32 \mathrm{~S}, 217 \mathrm{~S}$, and $216 \mathrm{~S}$, water levels are higher in the shallow rock zone than in the clastic zone; here the shallow rock zone discharges to the overlying clastic zone.

\section{Water Quality}

General

In coastal areas, ground water in the surficial aquifer system may be very saline as a result of lateral saltwater intrusion. In agricultural areas, the salinity of surficial ground water may be high because of the salinity of irrigation water or contamination of the shallow ground water with deeper, more saline water, through deteriorated or leaking well casings.

Table 4 lists representative analyses of water from 8 wells in the shallow rock zone, 7 wells in the clastic zone, and 1 well in the shallow rock zone (IS) that probably contains intruded saltwater. Also given in the table are ranges of concentrations of selected constituents in water from 39 wells in the shallow rock zone (depth $>75$ feet) and 51 wells in the clastic zone (depth $<75$ feet). 
Table 4.--Representative analyses and ranges in concentrations of constituents in water from wells completed in the clastic and shallow rock zones of the surficial aquifer system

[Concentrations are in milligrams per liter]

REPRESENTATIVE ANALYSES

\begin{tabular}{|c|c|c|c|c|c|c|c|c|c|c|}
\hline $\begin{array}{l}\text { Wel1 } \\
\text { No. }\end{array}$ & $\begin{array}{l}\text { Depth } \\
\text { (feet) }\end{array}$ & Sodium & $\begin{array}{l}\text { Potas- } \\
\text { sium }\end{array}$ & $\begin{array}{l}\text { Cal- } \\
\text { cium }\end{array}$ & $\begin{array}{l}\text { Magne - } \\
\text { sium }\end{array}$ & Iron & $\begin{array}{l}\text { Hard- } \\
\text { ness }\end{array}$ & $\begin{array}{l}\text { Bicar- } \\
\text { bonate }\end{array}$ & $\begin{array}{l}\text { Chlo- } \\
\text { ride }\end{array}$ & $\begin{array}{l}\text { Sul- } \\
\text { fate }\end{array}$ \\
\hline
\end{tabular}

Clastic zone (<75 feet in depth)

\begin{tabular}{rrrrrrrrrrr}
\hline $32 \mathrm{~S}$ & 53 & 26 & 0.7 & 105 & 6.5 & 0.92 & 289 & 330 & 48 & 21 \\
$38 \mathrm{~S}$ & 55 & 12 & .6 & 76 & 4.3 & .67 & 208 & 224 & 16 & 9 \\
$161 \mathrm{~S}$ & 53 & 39 & 13.3 & 158 & 7.9 & 2.9 & 428 & 540 & 51 & $<1$ \\
$167 \mathrm{~S}$ & 53 & 32 & 2.4 & 54 & 3.2 & 1.6 & 148 & 464 & 65 & 20 \\
$177 \mathrm{~S}$ & 41 & 18 & .4 & 87 & 2.5 & .3 & 227 & 366 & 40 & 0 \\
$216 \mathrm{~S}$ & 49 & 67 & .9 & 84 & 2.9 & .05 & 222 & 310 & 120 & 40 \\
$317 \mathrm{~S}$ & 35 & 14 & 2.8 & 5.1 & 3.2 & .13 & 25.9 & 26.8 & 26 & 1 \\
\hline
\end{tabular}

Shallow rock zone ( $>75$ feet in depth)

\begin{tabular}{crrrrrrrrrrr}
\hline $1 \mathrm{~S}^{1}$ & 147 & 14,000 & 500 & 630 & 1,900 & 22.0 & 9,393 & 922 & 30,250 & 4,000 \\
$31 \mathrm{~S}$ & 143 & 30 & 5.6 & 63 & 9 & 1.5 & 194 & 291 & 41 & $<1$ \\
$39 \mathrm{~S}$ & 123 & 43 & 4.5 & 90 & 8.7 & .5 & 261 & 322 & 60 & $<1$ \\
$162 \mathrm{~S}$ & 150 & 44 & 1.9 & 112 & 8.4 & 2.9 & 315 & 372 & 73 & $<1$ \\
$168 \mathrm{~S}$ & 144 & 19 & 3.7 & 84 & 3.9 & 8.2 & 226 & 464 & 25 & 0 \\
$178 \mathrm{~S}$ & 137 & 39 & 2.0 & 78 & 6.0 & 3.1 & 220 & 337 & 40 & 0 \\
$217 \mathrm{~S}$ & 133 & 26 & 7.1 & 26 & 18 & .4 & 139 & 239 & 35 & 0 \\
$239 \mathrm{~S}$ & 140 & 44 & 10 & 27 & 16 & .6 & 133 & 209 & 45 & 0 \\
$316 \mathrm{~S}$ & 134 & 35 & 2.9 & 36 & 21 & 1.2 & 176 & 197 & 50 & 0 \\
\hline
\end{tabular}

RANGES OF CONCENTRATIONS

\begin{tabular}{|c|c|c|c|c|c|c|c|c|c|}
\hline Range & Sodium & $\begin{array}{l}\text { Potas - } \\
\text { sium }\end{array}$ & $\begin{array}{l}\text { Cal- } \\
\text { cium }\end{array}$ & $\begin{array}{l}\text { Magne - } \\
\text { sium }\end{array}$ & Iron & $\begin{array}{l}\text { Hard- } \\
\text { ness }\end{array}$ & $\begin{array}{l}\text { Bicar- } \\
\text { bonate }\end{array}$ & $\begin{array}{l}\text { Chlo- } \\
\text { ride }\end{array}$ & $\begin{array}{l}\text { Sul- } \\
\text { fate }\end{array}$ \\
\hline \multicolumn{10}{|c|}{ Clastic zone ( 51 we 11 s $<75$ feet in depth) } \\
\hline $\begin{array}{l}\text { Low } \\
\text { High }\end{array}$ & $\begin{array}{r}11 \\
520 \\
\end{array}$ & $\begin{array}{r}2 \\
13.3 \\
\end{array}$ & $\begin{array}{r}21 \\
158 \\
\end{array}$ & $\begin{array}{r}2 \\
76 \\
\end{array}$ & $\begin{array}{l}0.3 \\
8.1 \\
\end{array}$ & $\begin{array}{l}180 \\
328 \\
\end{array}$ & $\begin{array}{l}169 \\
540 \\
\end{array}$ & $\begin{array}{r}20 \\
535 \\
\end{array}$ & \\
\hline
\end{tabular}

Shallow rock zone ( 39 wells $>75$ feet in depth)

\begin{tabular}{lrccccccrr}
\hline Low & 16 & 0.5 & 24 & 0.5 & 0.3 & 240 & 154 & 10 & 0 \\
High & 160 & 10 & 162 & 53 & 8.2 & 434 & 390 & 415 & 185 \\
\hline
\end{tabular}

${ }^{1}$ Indicates lateral intrusion. 


\section{Occurrence of Chlorides}

Chloride concentrations of water from wells more than 75 feet deep in the surficial aquifer system in eastern Indian River County are below $100 \mathrm{mg} / \mathrm{L}$, except in an area along Sebastian Creek and along the Indian River near the Vero Beach well field, where concentrations are above $250 \mathrm{mg} / \mathrm{L}$ (fig. 31). In this figure, the $250 \mathrm{mg} / \mathrm{L}$ chloride line generally parallels the Indian River but bows inland toward the Vero Beach well field. Chloride concentrations increase from about $250 \mathrm{mg} / \mathrm{L}$ just east of the Vero Beach well field to more than $20,000 \mathrm{mg} / \mathrm{L}$ near the Indian River.

Chloride concentrations of water from we11s 40 to 75 feet deep in the clastic zone also increase in an easterly direction, but values are not as high along the Indian River (fig. 32). Chloride concentrations west of the Indian River are generally less than $250 \mathrm{mg} / \mathrm{L}$. Between the Vero Beach well field and the Indian River, chloride concentrations range from 50 to $100 \mathrm{mg} / \mathrm{L}$. Concentrations greater than $250 \mathrm{mg} / \mathrm{L}$ occur in a small area bisected by Main Canal west of the Vero Beach well field, in the Sebastian Creek area, and on the Barrier Island.

Many wells in the Floridan aquifer system are cased to the top of the Hawthorn Formation, are more than 20 years old, and were constructed with steel casing that may be corroded through. Eastern Indian River County is a discharge area of the Floridan aquifer system and corroded-through casings of wells that tap the system could allow water from the Floridan aquifer system to intrude into the surficial aquifer system. Six cross sections in the eastern part of the county (fig. 33) show the relation between chloride concentration in ground water and the depths of wells (figs. 34-37). Interpretation of data shown in the cross sections indicates several patterns of chloride occurrence. Water from a few wells deeper than 80 feet have higher chloride concentrations than adjacent wells of near the same depth (figs. 34 and 35). The high concentrations may be due to intrusion of the shallow rock zone by more saline water from nearby wells in the Floridan aquifer system.

Sections E-E' and G-G' (figs. 35 and 36) show high chloride concentrations in water from a few wells less than about 80 feet deep. Along crosssection E-E' (fig. 35), chloride concentrations of water in three wells in the surficial aquifer system with depths less than 25 feet equal or exceed $180 \mathrm{mg} / \mathrm{L}$. Along section G-G' (fig. 36), the lowest chloride concentration in water from the nine wells plotted in the Floridan aquifer system is $180 \mathrm{mg} / \mathrm{L}$. The high chloride concentrations found in water from these relatively shallow wells in the surficial aquifer system may be due to downward seepage of irrigation water from the Floridan aquifer system or from wells in the Floridan aquifer system with corroded-through casings near the water table. The city of Vero Beach and the St. Johns River Water Management District have plugged several wells in the Floridan aquifer system that were leaking relatively high chloride concentration water into the surficial aquifer system through corroded casings. A common practice in the development of citrus groves into an urbanized area has been to bury existing wells in the Floridan aquifer system. As a consequence, the location of many wells in the Floridan aquifer system that potentially could cause intrusion problems is unknown. 


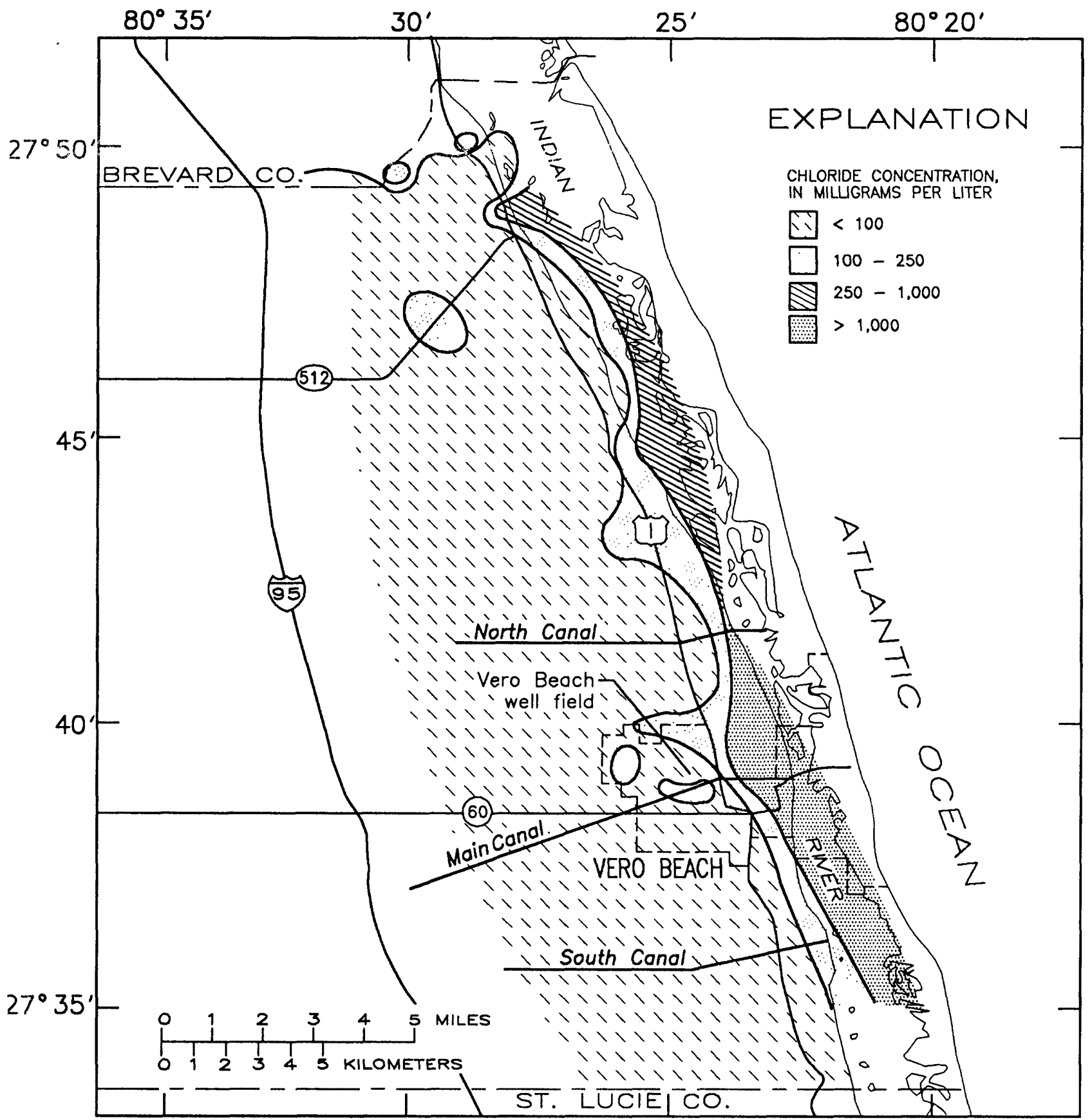

Figure 31.--Chloride concentrations in water from wells completed in the shallow rock zone (depths greater than 75 feet), 1982-83. 


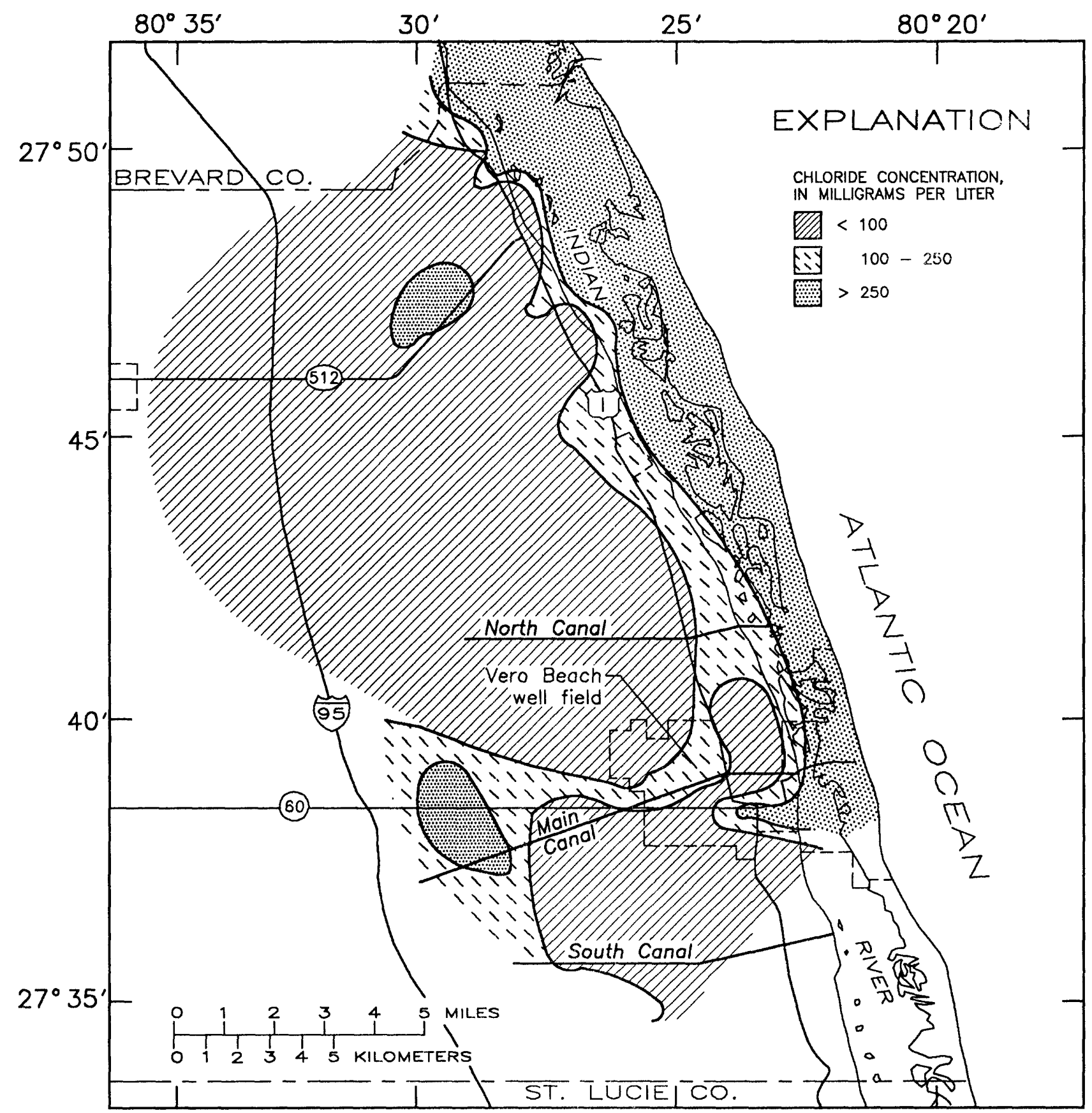

Figure 32.--Chloride concentrations in water from wells completed in the clastic zone (depths between 40 and 75 feet), 1982-83. 


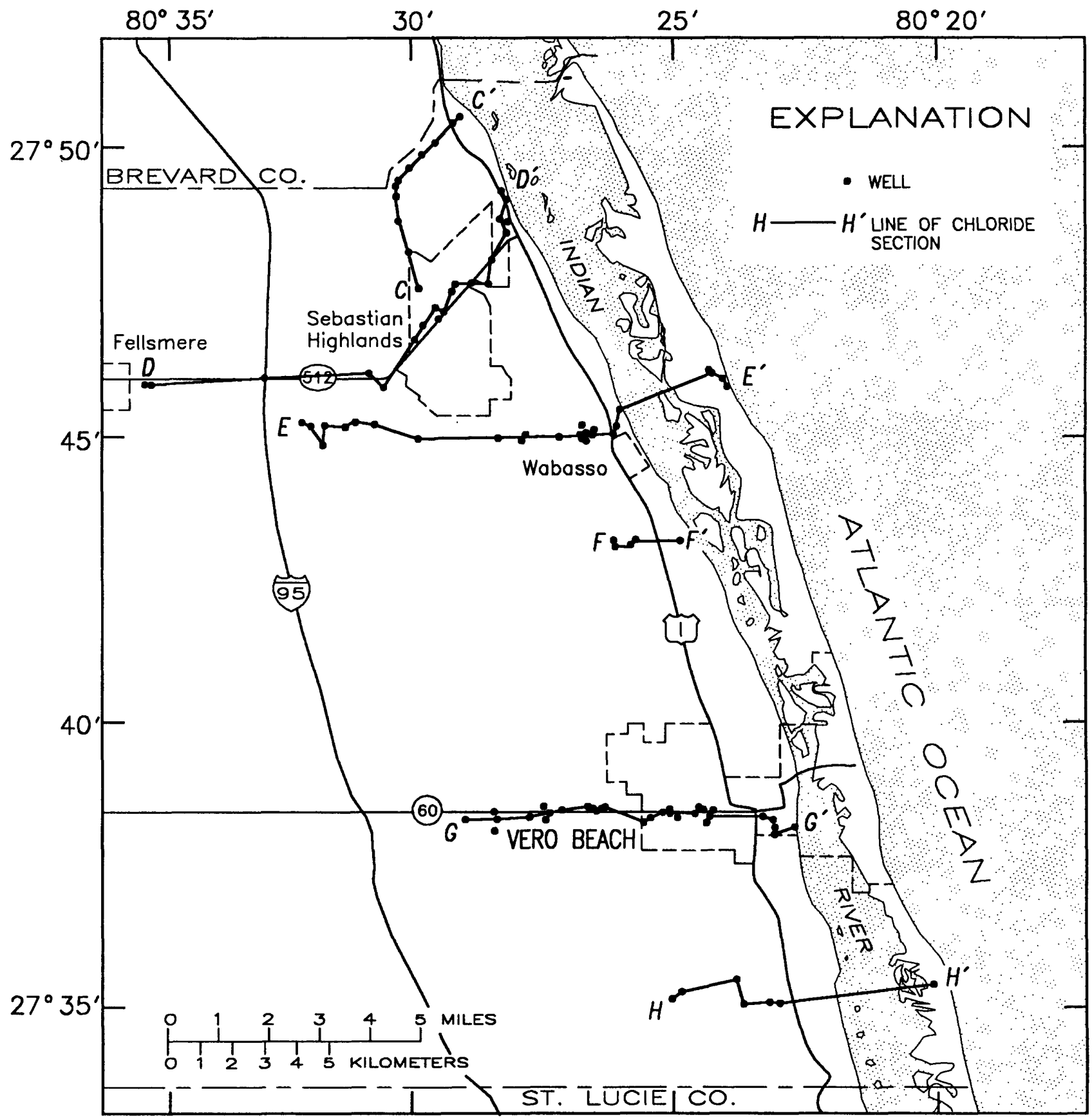

Figure 33.--Location of lines of chloride sections (sections shown in figs. 34-37). 


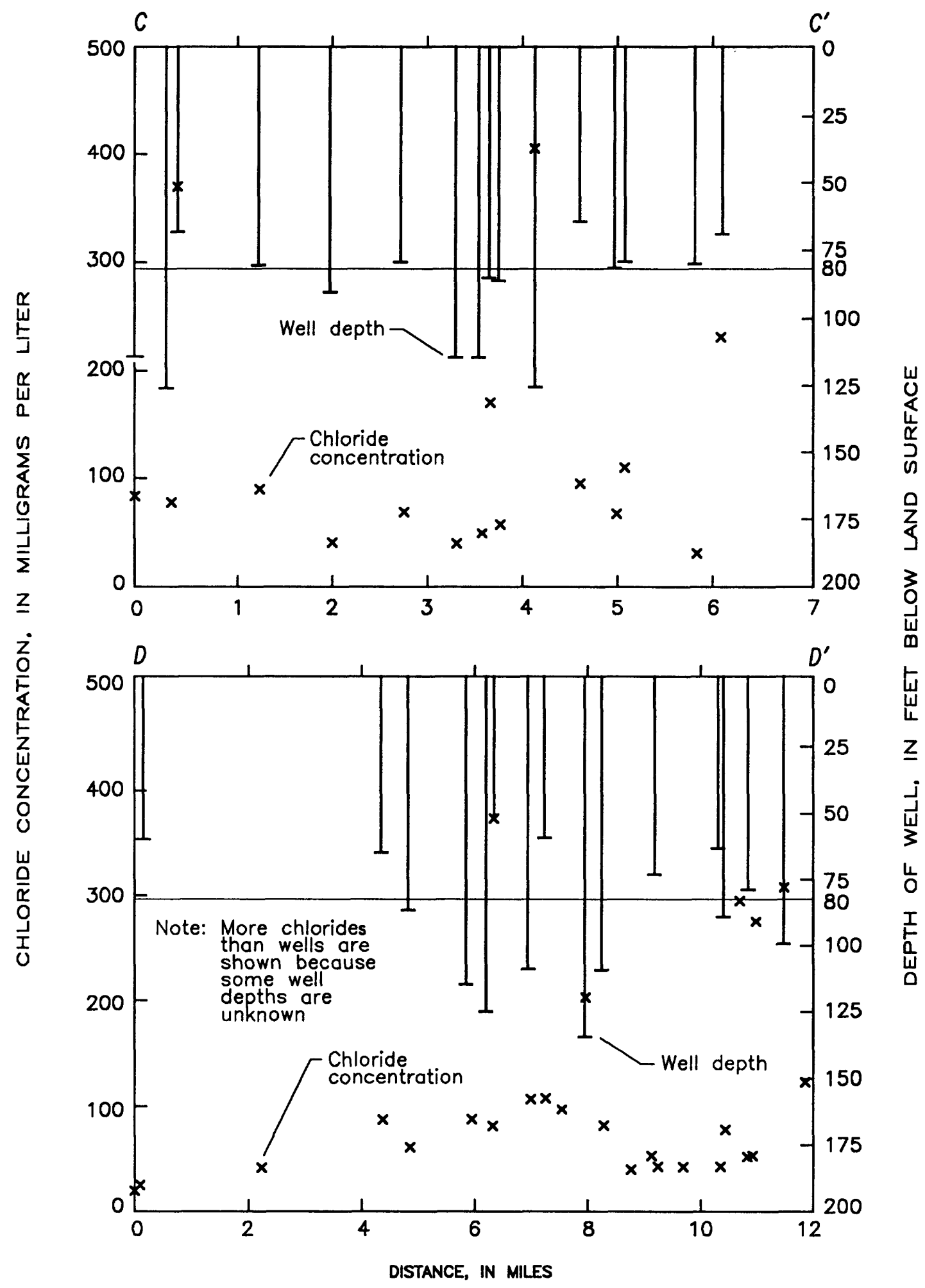

Figure 34.--Chloride concentrations in water and depth of wells in the surficial aquifer system along lines of section $C-C^{\prime}$ and $D-D^{\prime}$ (lines of section shown in fig. 33). 


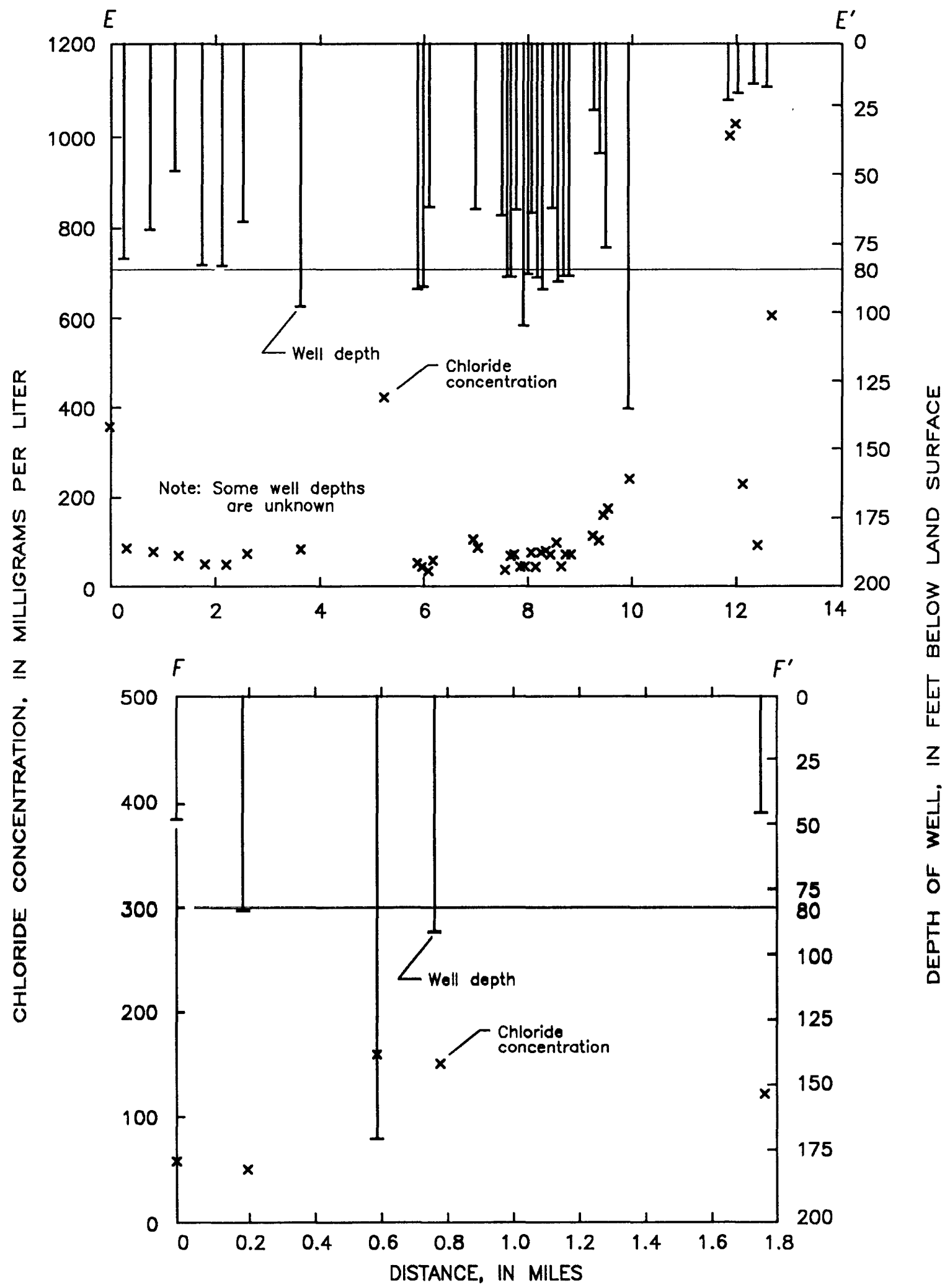
Figure 35.--Chloride concentrations in water and depth, of wells in the
surficial aquifer system along lines of section $E-E$ and $F-F$, (lines of section shown in fig. 33). 


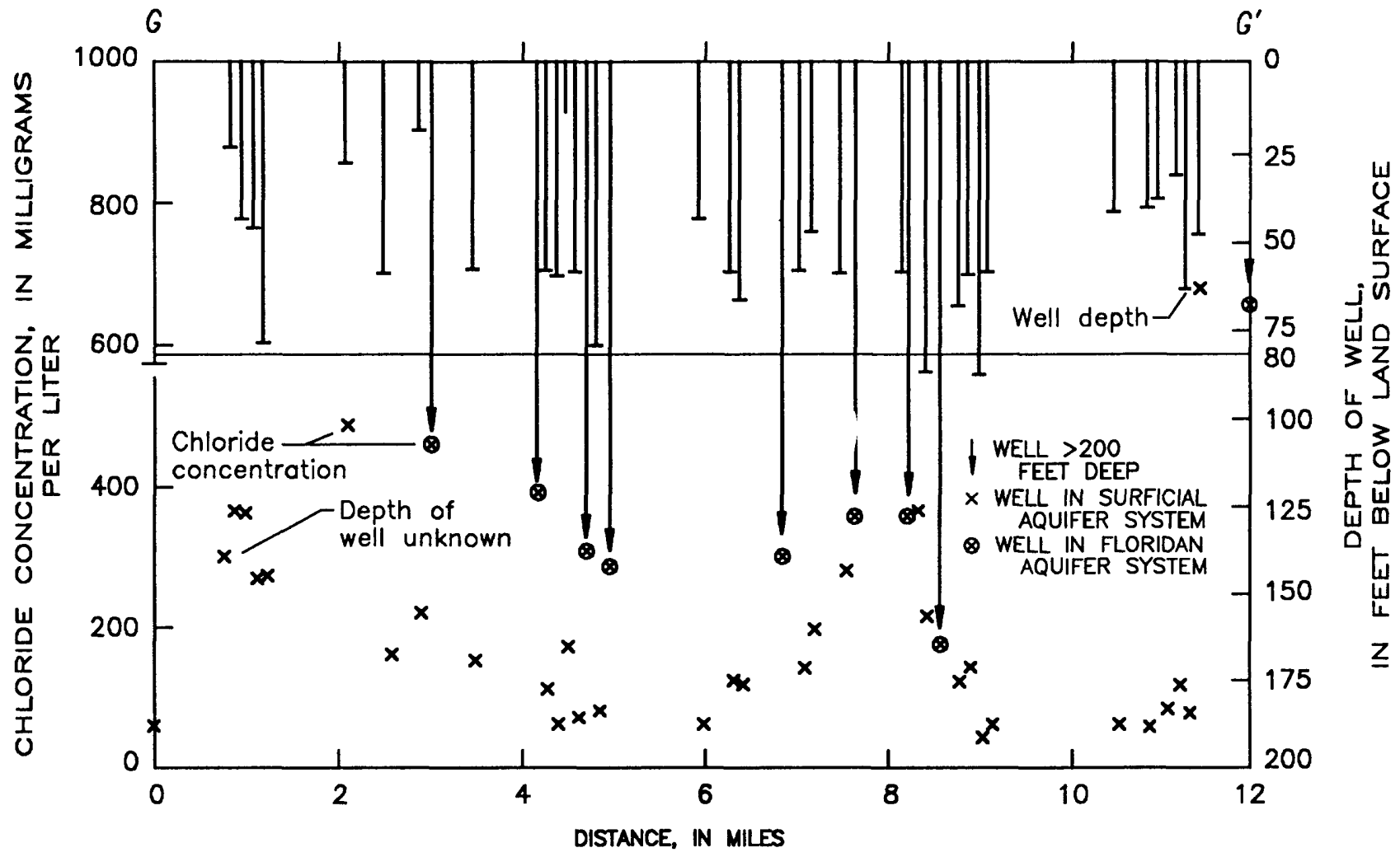

Figure 36.--Chloride concentration in water and depth of wells in the surficial and Floridan oquifer systems along line of section $G-G^{\prime}$ (line of section shown in fig. 33).

Areal patterns of occurrence and depth of occurrence of high chloride concentrations in water from wells often suggest a particular source for the high concentration. For example, when the chloride concentrations of water from wells increase with depth and are anomalously high, such as in the Sebastian Creek area, the cause may be intrusion by leakage, at depth, of water from wells that tap the Floridan aquifer system. Also, in areas where the chloride concentration of water is higher in a shallow well than in nearby deeper wells, such as west of Vero Beach straddling State Road 60, the cause is probably downward infiltration of Floridan aquifer system irrigation water or seepage from system wells. Along the coastal sections of Indian River County, the high chloride concentrations of water in many of the wells greater than 40 feet deep is probably due to the lateral intrusion of seawater.

\section{Occurrence of Chlorides in the Vero Beach Area}

Chloride concentrations in water from observation wells in the Vero Beach well field change in response to water-level fluctuations (see figs. 29 and 30) caused by pumping (discharge) and by recharge. Concentrations generally increase when water levels decline and decrease when water levels rise. However, in monitor well loos, located just south of Main Canal, chlorides have increased though water levels are trending upward. Between 


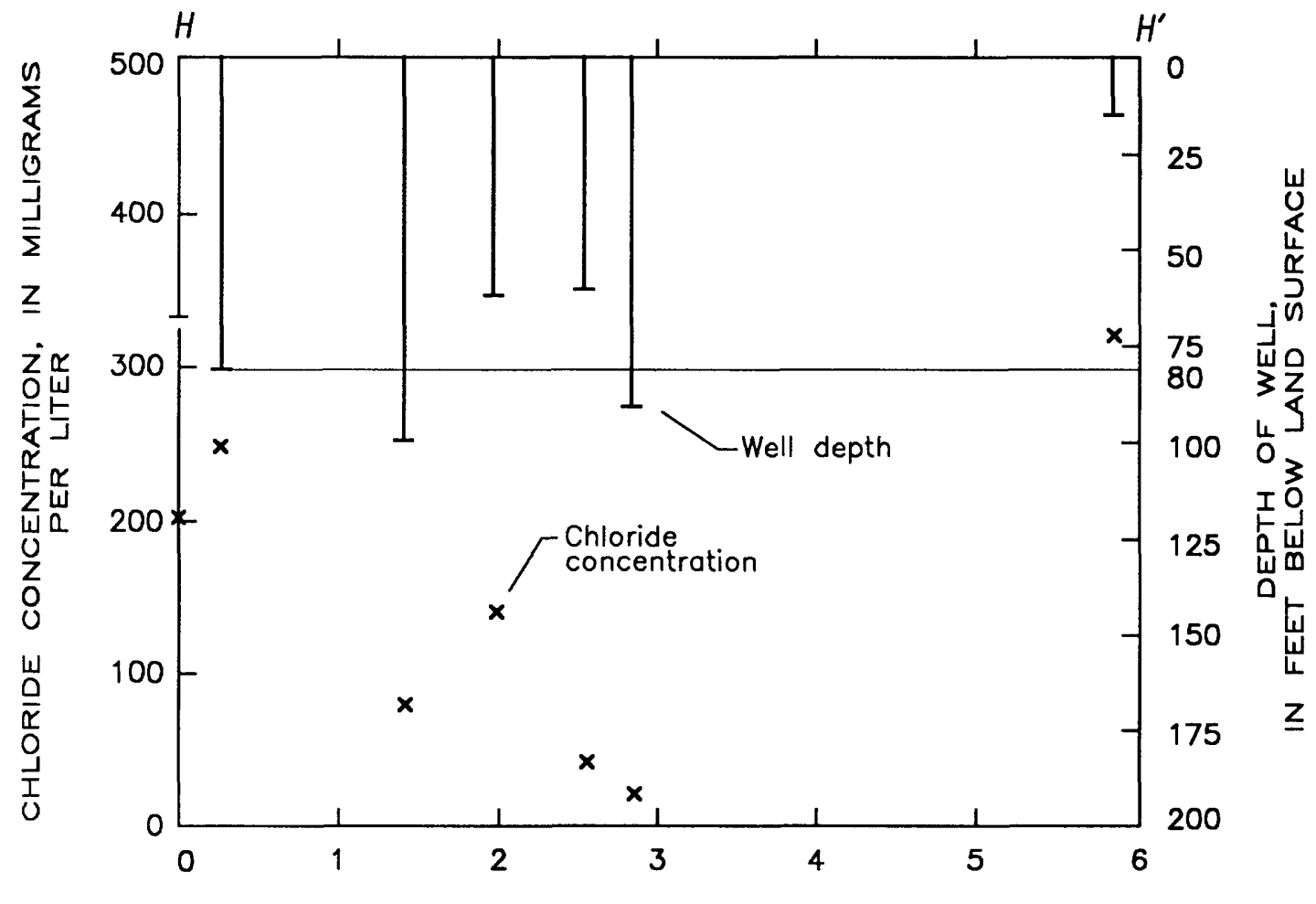

DISTANCE, IN MILES

Figure 37.--Chloride concentration in water and depth of wells in the surficial aquifer system along line of section $H-H^{\prime}$ (line of section shown in fig. 33).

September 1981 and June 1982, chloride concentrations increased linearly to about $300 \mathrm{mg} / \mathrm{L}$, and through 1983 and 1984 averaged about $300 \mathrm{mg} / \mathrm{L}$ (see figs. 39 and 40). The high chloride concentration found in wel1 $100 \mathrm{~s}$ and observation wells $84 \mathrm{~S}$ and $95 \mathrm{~S}$ may indicate a plume of high chloride water moving toward the southeast (fig. 39). Chloride concentrations of 320 and $144 \mathrm{mg} / \mathrm{L}$ also occurred south of Main Canal in observation we11s 95S and 84S, respectively, (fig. 21) in June 1984 (fig. 40). The high chloride concentration in water from wells $100 \mathrm{~S}, 95 \mathrm{~S}$, and $84 \mathrm{~S}$ may be due to leakage from the corroded-through casings of wells in the Floridan aquifer system or recharge of high chloride concentration water from the canal when ground-water levels are periodically lower than the maximum stage of Main Canal (fig. 29).

Chloride concentrations during the period 1979 to 1984 are shown for three salinity observation wells (we11s 119S, 125S, and 126S, fig. 23) in figure 38. In June 1981, water in salinity observation wel1 126S, located between the Vero Beach well field and the Indian River (fig. 21), had a chloride concentration of $4,900 \mathrm{mg} / \mathrm{L}$. A year later, following the 1981 drought, the concentration increased to $14,000 \mathrm{mg} / \mathrm{L}$. However, during above normal precipitation periods in 1983 and 1984, chloride concentrations were about $4,500 \mathrm{mg} / \mathrm{L}$ (fig. 38). The rise and fall of chloride concentrations in well $126 \mathrm{~S}$ indicates that the position of the freshwater-saltwater interface 
probably fluctuates in response to rainfall and withdrawals from wells. During extremely dry periods, the interface moves toward the well field. The amount of movement, however, may be small. Chloride concentration in salinity observation well $125 \mathrm{~S}$, located 1,000 feet west of $126 \mathrm{~S}$, remained virtually unchanged between 1979 and 1984 (fig. 38).

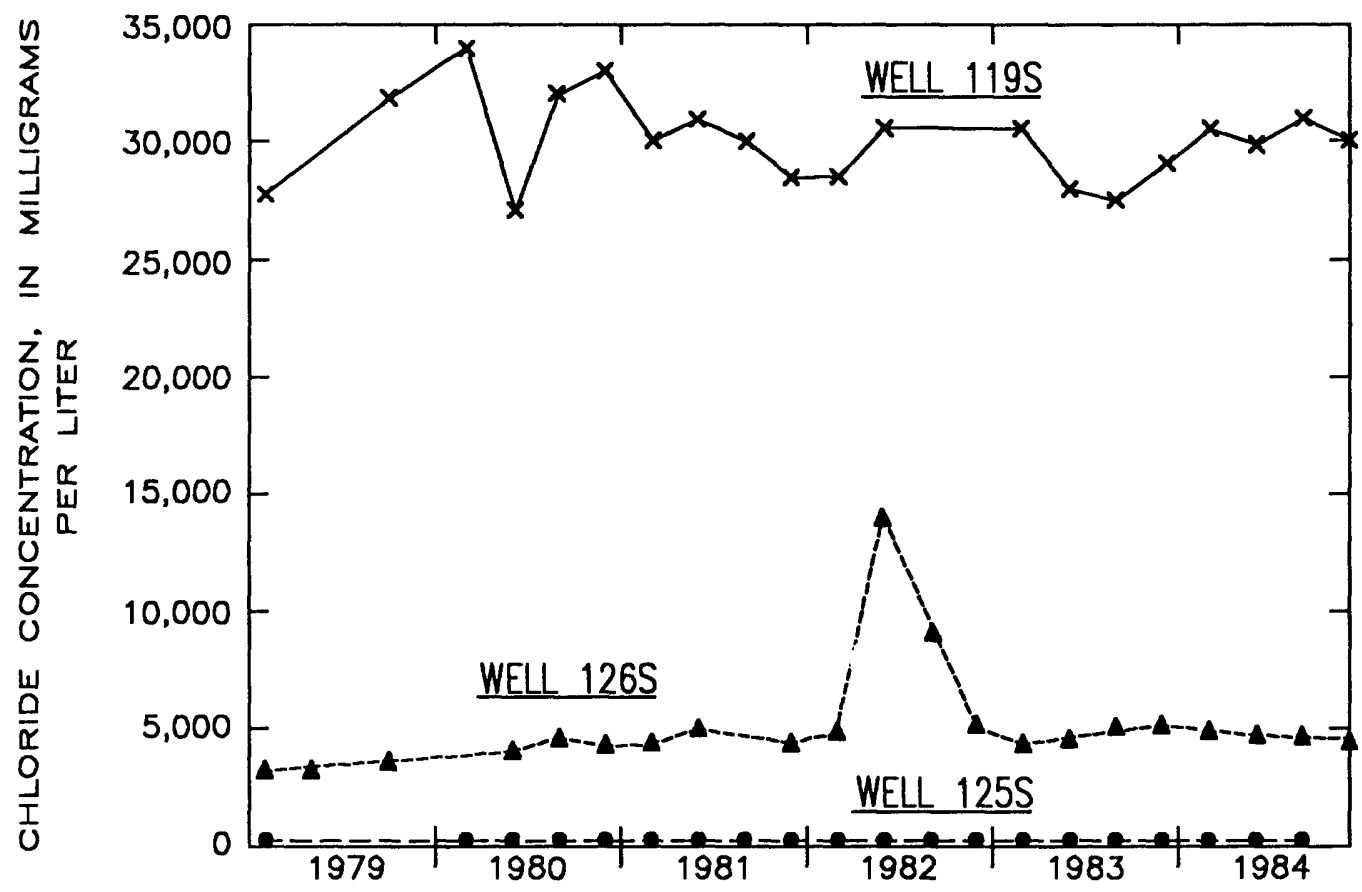

Figure 38.--Chloride concentrations in water from three salinity observation wells, 1979-84.

Chloride concentrations in the Vero Beach well field in June 1981 and June 1984 are shown in figures 39 and 40 . Excluding the area east of the well field, the highest chloride concentrations generally occur south of Main Canal. Concentrations are lowest in the area of the airstrip (fig. 39), coincident with the area of maximum drawdown in the well field. The low chloride concentrations in the area of maximum drawdown may be due to a high recharge rate that captures relatively high quality rainfall in that area. Pumping, therefore, causes the water table to decline and thus provides room for fresh recharge water to be stored. A comparison of the chloride maps in figures 39 and 40 indicate that the position of the $1,000 \mathrm{mg} / \mathrm{L}$ chloride line did not change appreciably between 1981 and 1984 .

Chloride concentrations of water in most wells in the Vero Beach well field have changed little in recent time, (see fig. 27 as an example). Between 1976 and 1983, the average chloride concentration increased about $36 \mathrm{mg} / \mathrm{L}$ in six production wells and was unchanged in four others. The increases in chloride concentrations were from scattered wells and are probably related to the increase in well field pumpage from $5.44 \mathrm{Mgal} / \mathrm{d}$ in 1976 to $8.00 \mathrm{Mgal} / \mathrm{d}$ in 1983 (fig. 27). 


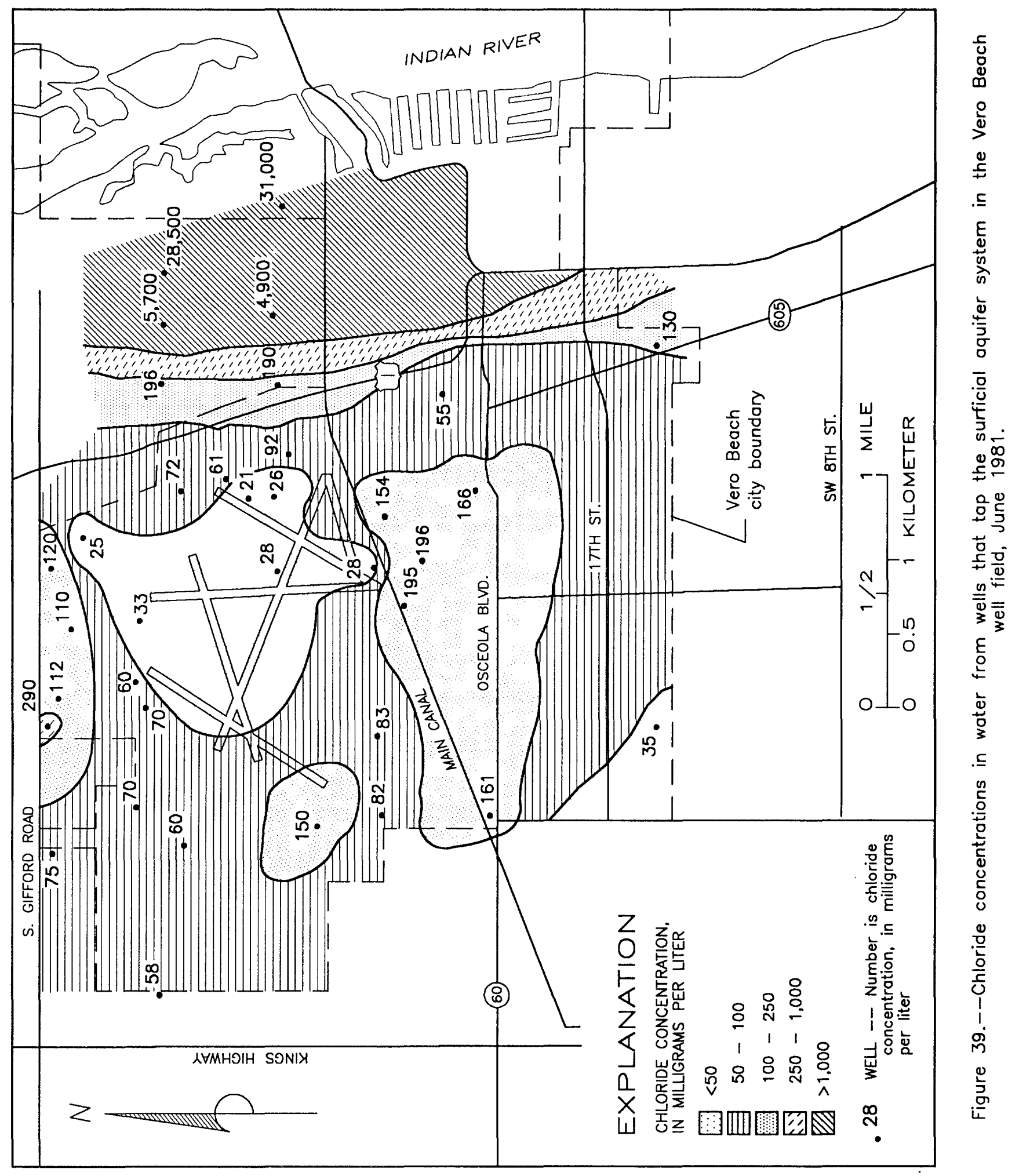




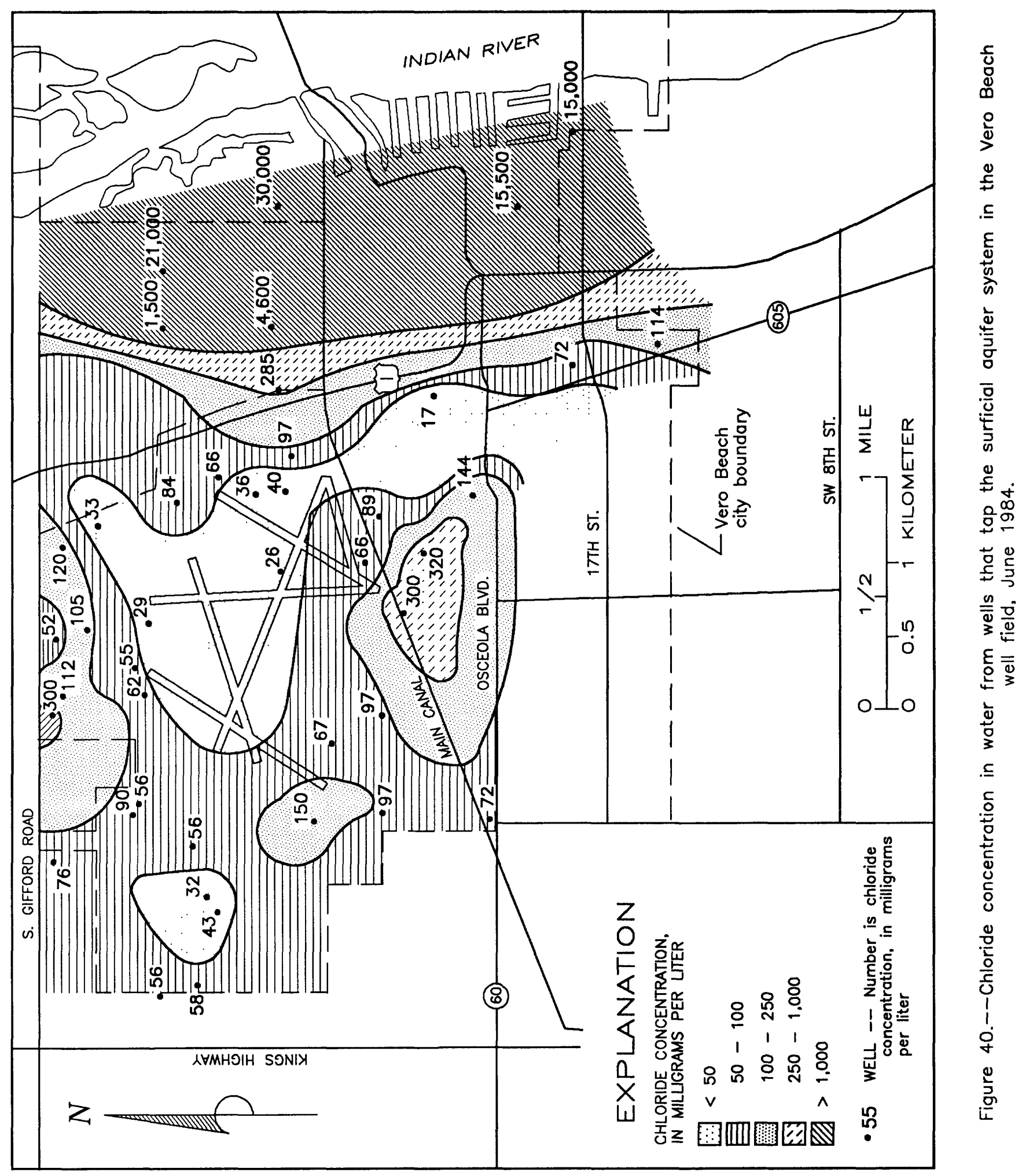




\section{Potential Development}

Tibbals (1978, p. 11) related evapotranspiration to the depth of the water table in east central Florida. Assuming this expression is valid for Indian River County where the water table averages 2 feet below land surface, evapotranspiration in the county is about $42 \mathrm{in} / \mathrm{yr}$ (inches per year). If the $42 \mathrm{in} / \mathrm{yr}$ of evapotranspiration is subtracted from an average rainfall of about 52 in/yr for eastern Indian River County, and assuming no runoff, the remainder of about $10 \mathrm{in} / \mathrm{yr}$ is net natural recharge to the surficial aquifer system in eastern Indian River County.

On the basis of hydrologic characteristics of the $140-\mathrm{mi}^{2}$ area that lies between U.S. Highway 1 and I-95, and assuming the surficial aquifer system receives $10 \mathrm{in} / \mathrm{yr}$ of natural recharge in that area, about $67 \mathrm{Mgal} / \mathrm{d}$ of water is theoretically available for withdrawal from the system in eastern Indian River County. It should be recognized that the estimate of availability was obtained from a simplified solution of a complex problem. The theoretical and actual amount of water available for withdrawal may differ considerably due to the many factors not considered. For example, not all the theoretical amount of water available can be withdrawn--some water is retained in the aquifer. A1so, if the natural recharge rate is altered by development, additional or lesser amounts of water may be available. However, the amount indicated implies that sufficient water for pub1ic supply may be available for future use in the county if withdrawals are properly managed.

In east Indian River County, high-yielding wells completed in the surficial aquifer system are most likely to be found along the Atlantic Coastal Ridge west of U.S. Highway 1. In places, however, water quality there may not be acceptable because of high concentrations of undesirable constituents. We1ls that tap both the clastic zone and the shallow rock zone will probably be the most productive.

In places, uncontrolled flowing wells that tap the Floridan aquifer system have apparent1y allowed high-chloride water to intrude into the surficial aquifer system. Some of these wells have been plugged by the St. Johns River Water Management District as part of their well plugging program. Problems relating to saltwater intrusion of the surficial aquifer system could possibly be avoided or lessened if (1) all new wells are tested for saltwater during installation and production, (2) all unused we11s are plugged from bottom to top to prevent the upward migration of saltwater and, (3) the current (1985) monitoring program is continued.

\section{GEOHYDROLOGY OF THE FLORIDAN AQUIFER SYSTEM}

\section{Description of the Hydrologic Units}

About 65 percent of a11 ground water used in the county is from the Floridan aquifer system. In this report, the terminology and definitions relating to the Floridan aquifer system used by Miller (1986) are closely followed but with a few exceptions. The Floridan aquifer system consists of limestone and dolomite, about 2,800 feet thick, that commonly yields abundant supplies of water to we11s. Previous to a recent study of the Tertiary limestone aquifer system in the southeastern states, the Floridan aquifer 


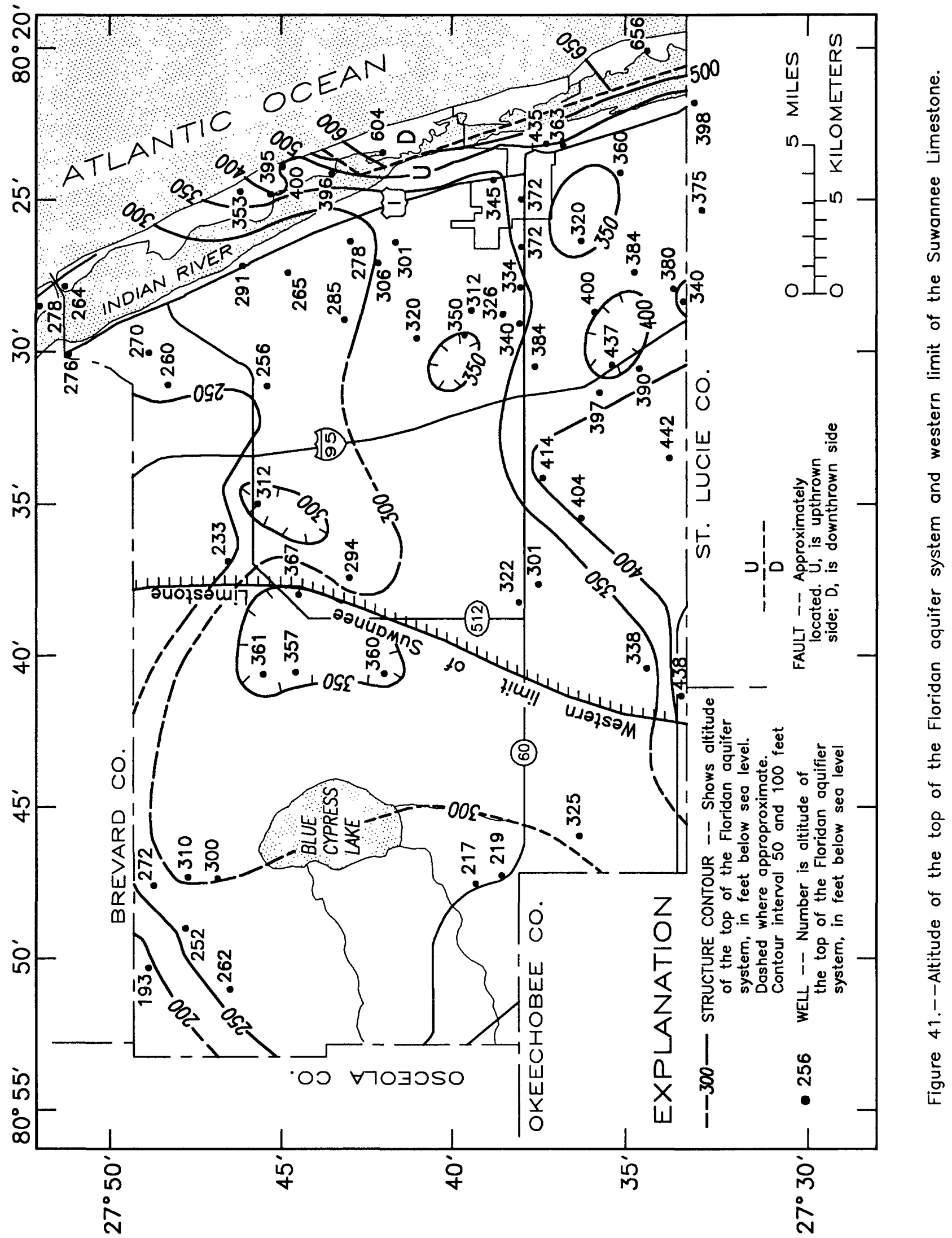


system was termed the "Floridan aquifer" (Miller, 1986, p. B44). Miller (1986, p. B45) describes the Floridan aquifer system as a vertically continuous sequence of generally high permeability carbonate rocks, mostly of middle and late Tertiary age, that are several orders of magnitude more permeable than the rocks that bound the system above and below.

Though the Floridan aquifer system is reported to generally cross formation and age boundaries, Miller (1986, p. B46) reports that, regionally, the top of the system is the Suwannee Limestone, but if absent, is the Ocala Limestone. Accordingly, in Indian River County, the Floridan aquifer system in descending order consists of the Suwannee Limestone (where present, fig. 41), Ocala Limestone, Avon Park Formation, Oldsmar Formation, and part of the Cedar Keys Formation (Miller, 1986, p. B46). The lower part of the Avon Park Formation was formerly known as the Lake City Limestone. Because of sparse control and the interfingering of key marker beds, the base of the Floridan aquifer system is difficult to ascertain. One oil test well (well 172F) drilled to basement rock, and one injection well (well 32F) finished in the Oldsmar Formation are the only wells known to penetrate below the Avon Park Formation in Indian River County.

Because less-permeable carbonate rocks consistently occur as a unit within the Floridan aquifer system in peninsular Florida, Miller (1986, p. B45) separated the system in descending order into the Upper Floridan aquifer, a middle semiconfining unit, and the Lower Floridan aquifer. The Upper Floridan aquifer ranges in thickness from about 350 feet in the southwestern part of the county to about 650 feet in the northeast. The top of the Upper Floridan is the Suwannee Limestone in the eastern part of Indian River County and the Ocala Limestone in the west (fig. 41). The top generally slopes to the southeast and ranges in altitude from about -200 to -500 feet. The surface is apparently irregular due to erosion and dissolution. East of the Indian River fault trace (fig. 41), the altitude of the top of the Floridan aquifer system is as low as -650 feet (in the southeast corner of the county)--about 250 feet lower than the surface west of the fault trace (fig. 11).

For this investigation, the middle semiconfining unit is identified as a dense dolomitic zone of variable thickness and low permeability and porosity that generally occurs near the middle of the Avon Park Formation. Geophysical logs indicate that the middle semiconfining unit ranges from about 20 to 120 feet in thickness. The logs also suggest that the top of the unit ranges widely in altitude ( -613 to $-1,450$ feet).

According to Miller (1986, p. B65), the Lower Floridan aquifer consists of a zone of low and high permeability subzones that lie between the middle semiconfining unit and the Sub-Floridan confining unit (lower confining unit of Miller, 1986) that underlies the Lower Floridan aquifer. The Sub-Floridan confining unit is a massively bedded anhydrite of extremely low permeability that is in the upper part of the Cedar Keys Formation (Miller, 1986, p. B46). Little information is available on the thickness of the Lower Floridan aquifer. Miller (1986, pl. 32) shows that the Lower Floridan aquifer in Indian River County ranges from about 1,600 to 2,000 feet in thickness and thickens to the northwest. Well $172 \mathrm{~F}$ is the only well known to completely penetrate the Cedar Keys. There, the altitude of the base of the Lower Floridan aquifer is about $-3,100$ feet. 


\section{Hydraulic Properties}

The hydraulic properties of the middle semiconfining unit and the Lower Floridan aquifer of the Floridan aquifer system are poorly known, so discussion of these properties relates mostly to the better-known characteristics of the Upper Floridan aquifer. Variations in the hydrologic characteristics of the rock strata within the Floridan aquifer system are complex and are closely related to the geologic framework of the system. The porosity and permeability of the rock strata that comprise the system result from combinations of (1) the original texture of the rock; (2) processes that have acted on the rock, such as dolomitization and recrystallization; (3) joints, fractures, and faults; and (4) mineral solution or precipitation. Most of the hydraulic (and water-quality) variations found in the Floridan aquifer system in Indian River County probably occur because of one or a combination of the above factors. The combinations that are in effect may cause considerable variation in yield and water quality in nearby wells of equal depth. Flow-meter data show that water-producing zones within a borehole are typically discrete and may occur at different altitudes in adjacent boreholes. However, some boreholes contribute water throughout.

The permeability of the Upper Floridan aquifer is reported to be generally higher than that of the Lower Floridan (Miller, 1986, p. B54). The most productive water yielding zones are probably in the Avon Park Formation. The rate of ground-water circulation is relatively high in the Upper Floridan aquifer compared to circulation in the Lower Floridan aquifer, but flow logs indicate some wells that penetrate the Lower Floridan obtain a high percentage of their yield from that part of the aquifer system. Except east of the Indian River fault trace, (on the downthrown side of the fault), wells more than 700 feet deep in the eastern part of the county are probably completed in the Lower Floridan aquifer. These deeper wells were probably installed because the Upper Floridan could not supply sufficient water for a particular need (chiefly citrus irrigation).

Yields of wells that tap the Floridan aquifer system can be related to the specific capacity of the well, and in an approximate manner, to the transmissivity of the penetrated aquifer.

Transmissivity and associated data that can be used to determine hydraulic properties of the Floridan aquifer system are available for five test sites in Indian River County (fig. 42 and table 5). In addition, Tibbals (1981, fig. 6) determined a model-derived transmissivity range of 100,000 to $200,000 \mathrm{ft}^{2} / \mathrm{d}$ for the Upper Floridan aquifer in Indian River County based on a regional-scale model calibration. Planert and Aucott (1985, p. 19) reported a transmissivity of $10,000 \mathrm{ft}^{2} / \mathrm{d}$ for well site $216 \mathrm{~F}$ in Brevard County near northwestern Indian River County. For a model calibration, the area bordering northern Indian River County was assigned a transmissivity value of $65,000 \mathrm{ft}^{2} / \mathrm{d}$ by Planert and Aucott $(1985, \mathrm{p}$. 47) for both the Upper and Lower Floridan aquifers.

The highest transmissivity reported in the county $\left(1.5 \times 10^{6} \mathrm{ft}^{2} / \mathrm{d}\right)$ was from an aquifer test run on an injection well (32F) completed in the Boulder Zone (Kohout, 1965)--a zone within the Lower Floridan aquifer consisting of high permeability, fractured, and cavernous dolomite near the base of the oldsmar Formation. The Boulder Zone at that site occurs at a depth interval of about 2,400 to 3,000 feet. Miller (1986, p. B68), reports that the 


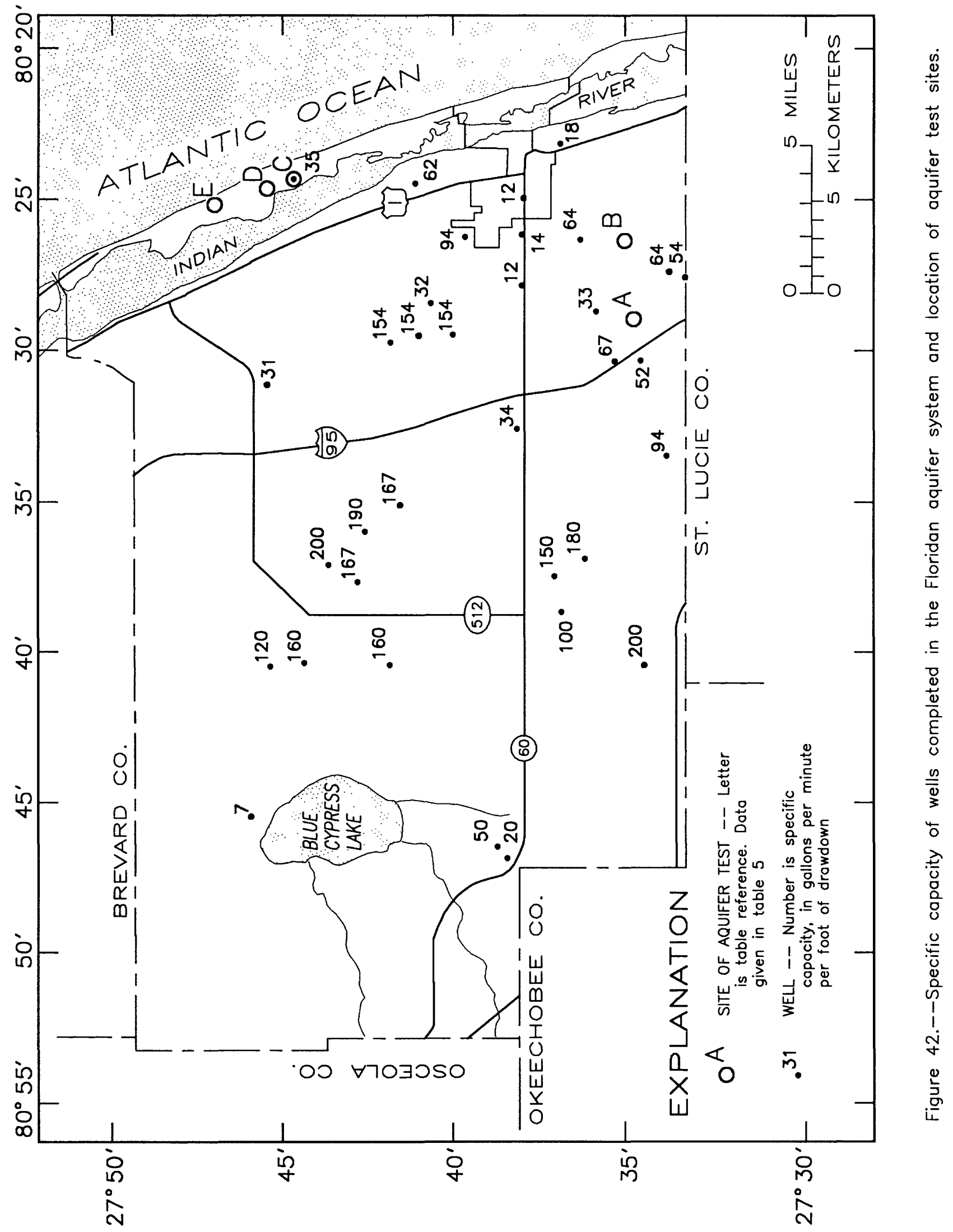


Table 5.--Transmissivities of the Floridan aquifer system at five sites in Indian River County

$\left[\mathrm{ft}^{2} / \mathrm{d}=\right.$ feet squared per day $]$

\begin{tabular}{|c|c|c|c|c|c|c|}
\hline $\begin{array}{l}\text { Refer- } \\
\text { ence } \\
\text { letter } \\
\text { (fig. 42) }\end{array}$ & $\begin{array}{l}\text { Well } \\
\text { No. }\end{array}$ & $\begin{array}{c}\text { Site } \\
\text { identification } \\
\text { No. }\end{array}$ & $\begin{array}{l}\text { Transmis - } \\
\text { sivity } \\
\left(\mathrm{ft} \mathrm{t}^{2} / \mathrm{d}\right)\end{array}$ & $\begin{array}{l}\text { Storage } \\
\text { coeffi- } \\
\text { cient }\end{array}$ & $\begin{array}{l}\text { Depth of } \\
\text { we11 (feet } \\
\text { below land } \\
\text { surface) }\end{array}$ & Source of data \\
\hline A & $32 \mathrm{~F}$ & 273510080285502 & $1,500,000$ & $\cdots$ & 13,005 & CH2M Hill (1979) \\
\hline \multirow[t]{2}{*}{ B } & $37 F$ & 273526080240701 & 50,000 & $4 \times 10$ & 745 & $\begin{array}{l}\text { Geraghty and } \\
\text { Miller (1981b) }\end{array}$ \\
\hline & 40F & 273536080240101 & 56,800 & $3.9 \times 10_{-4}^{-4}$ & 704 & Do. \\
\hline \multirow[t]{2}{*}{ C } & $137 \mathrm{~F}$ & 274445080235901 & 7,500 & $5 \times 10^{-3}$ & 1,000 & Bermes (1958) \\
\hline & $138 \mathrm{~F}$ & 274447080235301 & 4,800 & $1 \times 10_{-4}^{-4}$ & 860 & Do. \\
\hline \multirow[t]{2}{*}{ D } & $150 \mathrm{~F}$ & 274524080240801 & 17,600 & $6 \times 10^{-0}$ & 960 & $\begin{array}{l}\text { Seaburn and } \\
\text { Robertson }(1983 a)\end{array}$ \\
\hline & $154 \mathrm{~F}$ & 274532080241801 & 44,100 & $\cdots 10^{-3}$ & 1,000 & Do. \\
\hline \multirow[t]{3}{*}{ E } & $186 \mathrm{~F}$ & 274659080244301 & 19,400 & $1.4 \times 10_{-3}^{-3}$ & 700 & Bermes (1958) \\
\hline & $187 \mathrm{~F}$ & 274700080243901 & 20,100 & $1 \times 10^{-}$ & 1,000 & Do. \\
\hline & $188 \mathrm{~F}$ & 274700080245101 & 20,100 & $1.4 \times 10$ & 860 & Do. \\
\hline
\end{tabular}

${ }^{1}$ Interval tested was the 2,400- to 3,005-foot depth.

Boulder Zone is commonly found at depths of about 2,500 to 3,000 feet in south Florida, and that the transmissivity of the entire thickness of the zone may exceed $10^{7} \mathrm{ft}^{2} / \mathrm{d}$. The zone contains saline water, and is widely used as a receiving unit for municipal and other liquid wastes along the southeast coast of Florida.

Specific capacity data are more easily determined than transmissivity data, and are therefore more frequently available. The range of values of specific capacities of wells in the Floridan aquifer system in the county is large (fig. 42) and shows little areal pattern. The variability of specific capacity values is probably related to well diameter and depth of penetration but is probably due primarily to the irregular distribution and permeability of producing intervals in individual wells. Specific capacities of 37 wells range from 1 to 200 ( $\mathrm{gal} / \mathrm{min}$ )/ft and the median is 67 (gal/min)/ft (table 6). The map showing specific capacities (fig. 42) suggests lower than average specific capacities in the western part of the county, higher than average values in the central part, and probably low values east of the Indian River fault trace.

Flow rates of individual wells are usually indicative of the hydraulic characteristics of the aquifer penetrated, so high and low flow rates from wells of equivalent depth and diameter generally indicate correspondingly high and low specific capacities or transmissivities of the aquifer. Measured flow rates of wells that tap the Floridan aquifer system range from 30 to $2,000 \mathrm{gal} / \mathrm{min}$ with a median of $650 \mathrm{gal} / \mathrm{min}$. The largest reported flow rate in the county is about $6,000 \mathrm{gal} / \mathrm{min}$ from an injection we11 (well $30 \mathrm{~F}$ ) at a depth of 1,350 feet (CH2M Hill, 1979). Flow rates of wells are not only related to hydraulic characteristics of the yielding zones of the 
Table 6.--Specific capacity test data of selected wells that tap the Floridan aquifer system

$[\mathrm{gal} / \mathrm{min}=$ gallon per $\mathrm{minute} ;(\mathrm{gal} / \mathrm{min}) \mathrm{ft}=$ gallon per minute per foot $]$

\begin{tabular}{|c|c|c|c|c|c|c|c|}
\hline $\begin{array}{c}\text { Well } \\
\text { No. }\end{array}$ & $\begin{array}{l}\text { Well } \\
\text { identification } \\
\text { No. }\end{array}$ & $\begin{array}{l}\text { Casing } \\
\text { diam- } \\
\text { eter } \\
\text { (inches) }\end{array}$ & $\begin{array}{c}\text { Shut-in } \\
\text { water } \\
\text { leve1 } \\
\text { (feet } \\
\text { above } \\
\text { land } \\
\text { surface) }\end{array}$ & $\begin{array}{l}\text { Flowing } \\
\text { water } \\
\text { leve1 } \\
\text { (feet } \\
\text { above } \\
\text { land } \\
\text { surface) }\end{array}$ & $\begin{array}{l}\text { Draw- } \\
\text { down } \\
(\text { feet })\end{array}$ & $\begin{array}{l}\text { Flow- } \\
\text { rate } \\
\text { (gal/ } \\
\text { min) }\end{array}$ & $\begin{array}{l}\text { Specific } \\
\text { capacity } \\
{[(\text { gal/ }} \\
\mathrm{min}) / \mathrm{ft}]\end{array}$ \\
\hline $7 F$ & 273335080280901 & 8 & 12 & 0 & 12 & 650 & 54 \\
\hline $12 \mathrm{~F}$ & 273357080274901 & 8 & 12 & 1 & 11 & 700 & 64 \\
\hline $20 \mathrm{~F}$ & 273423080332201 & 8 & 13 & 4 & 9 & 850 & 94 \\
\hline $21 F$ & 273430080195601 & 6 & 30 & 0 & 30 & 30 & 1 \\
\hline $26 \mathrm{~F}$ & 273459080401201 & 12 & 15 & 10 & 5 & 1,000 & 200 \\
\hline $28 \mathrm{~F}$ & 273501080302101 & 8 & 12 & 1.5 & 10.5 & 1,600 & 152 \\
\hline $42 \mathrm{~F}$ & 273539080301901 & 4 & 12 & 6 & 6 & 400 & 67 \\
\hline $47 \mathrm{~F}$ & 273615080283501 & 8 & 10 & 1 & 9 & 300 & 33 \\
\hline $53 \mathrm{~F}$ & 273633080364301 & 20 & 14 & 4 & 10 & 1,800 & 180 \\
\hline $54 \mathrm{~F}$ & 273639080261501 & 6 & 8 & 1 & 7 & 450 & 64 \\
\hline $57 \mathrm{~F}$ & 273710080230601 & 8 & 29 & 4 & 25 & 450 & 18 \\
\hline $61 \mathrm{~F}$ & 273726080371501 & 10 & 16 & 4 & 12 & 1,800 & 150 \\
\hline $64 \mathrm{~F}$ & 273741080382701 & 10 & 15 & 7 & 8 & 800 & 100 \\
\hline $72 \mathrm{~F}$ & 273814080245201 & 4 & 10 & 6 & 4 & 50 & 12 \\
\hline $76 \mathrm{~F}$ & 273819080260101 & 4 & 11 & 6 & 5 & 70 & 14 \\
\hline $77 \mathrm{~F}$ & 273821080273901 & 4 & 9 & 5 & 4 & 50 & 12 \\
\hline $80 \mathrm{~F}$ & 273827080322001 & 8 & 12 & 5 & 7 & 240 & 34 \\
\hline $84 \mathrm{~F}$ & 273833080461901 & 6 & 12 & 10 & 2 & 40 & 20 \\
\hline $95 \mathrm{~F}$ & 273927080465701 & 8 & 13 & 1 & 12 & 600 & 50 \\
\hline $102 \mathrm{~F}$ & 274008080255301 & 8 & 9 & 1 & 8 & 750 & 94 \\
\hline $104 \mathrm{~F}$ & 274023080291401 & 10 & 11 & 0 & 11 & 1,700 & 154 \\
\hline $107 \mathrm{~F}$ & 274055080281301 & 5 & 13 & 4 & 9 & 285 & 32 \\
\hline $110 \mathrm{~F}$ & 274115080291401 & 10 & 11 & 0 & 11 & 1,700 & 154 \\
\hline $112 \mathrm{~F}$ & 274121080241701 & 6 & 28 & 16 & 12 & 750 & 62 \\
\hline $115 \mathrm{~F}$ & 274156080344301 & 12 & 15 & 9 & 6 & 1,000 & 167 \\
\hline $117 \mathrm{~F}$ & 274203080292901 & 12 & 13 & 0 & 13 & 2,000 & 154 \\
\hline $119 \mathrm{~F}$ & 274210080400301 & 10 & 22 & 17 & 5 & 800 & 160 \\
\hline $123 \mathrm{~F}$ & 274250080354401 & 12 & 13 & 8 & 5 & 950 & 190 \\
\hline $126 \mathrm{~F}$ & 274302080371501 & 10 & 20 & 14 & 6 & 1,000 & 167 \\
\hline $134 \mathrm{~F}$ & 274350080364501 & 12 & 16 & 11 & 5 & 1,000 & 200 \\
\hline $136 \mathrm{~F}$ & 274436080395801 & 10 & 20 & 15 & 5 & 800 & 160 \\
\hline $140 \mathrm{~F}$ & 274449080240001 & 5 & 24 & 16 & 8 & 280 & 35 \\
\hline $149 \mathrm{~F}$ & 274522080304301 & 4 & 14 & 10 & 4 & 125 & 31 \\
\hline $151 \mathrm{~F}$ & 274528080395801 & 10 & 20 & 15 & 5 & 600 & 120 \\
\hline $155 \mathrm{~F}$ & 274534080251101 & 6 & 36 & 8 & 28 & 200 & 7 \\
\hline $167 \mathrm{~F}$ & 274607080264001 & 6 & 21 & 1 & 20 & 150 & 7 \\
\hline $180 \mathrm{~F}$ & 274642080453601 & 3 & 11 & 4 & 7 & 50 & 7 \\
\hline $216 \mathrm{~F}$ & 275119080482401 & 12 & $\ldots$ & - - & 8.9 & 280 & 32 \\
\hline
\end{tabular}


wellbore, but also to pipe and wellbore hydraulics. Generally, the largest flow rates are from large-diameter wells ( 10 inches or more) and large diameter ( 8 inches or more) discharge pipes. Most wells that tap the Floridan aquifer system are capable of yielding several hundred gallons of water per minute without significant drawdown.

\section{Description of We11s that Tap the System}

The records of 250 wells in the Floridan aquifer system, which are stored in the Geological Survey computer files and shown in Supplementary Data II, represent only a small percentage of the wells that have been drilled in the study area. Uninventoried wells probably number several thousand. Some general observations pertaining to wells that tap the Floridan aquifer system in Indian River County can be made from field observations and from available records.

Depths of wells in the Floridan aquifer system in Indian River County are generally constrained by drilling costs and the potential of degradation of water quality with increased depth. The proposed use of water and the productivity of a well are the chief considerations for any we 11 installation. Therefore, wells are generally drilled to meet or to most closely approximate required yields and water-quality needs within economic limits. Inventoried wells range in depth from 233 to 1,272 feet with a median depth of 700 feet. A report by Bermes (1958, p. 32) indicates that in about 1950 wells in the Floridan aquifer system on the mainland were about 600 to 700 feet deep. Records of new wells (drilled since the 1981 drought) indicate that typical depths have increased--many wells extend to depths of 900 feet or more. The probable reason for the deeper wells is the demand for higher yields.

Wells completed in the Floridan aquifer system that yield excessively saline water are usually plugged or abandoned. However, in places where a modest amount of acceptable water can be obtained from the upper part of the we11, it may be more feasible to plug the bottom section of the well to seal off the lower saline zone rather than abandoning the wel1.

Well casings generally extend only to depths that allow the wellbore to remain open--usually into the Hawthorn Formation. Therefore, the bottom 600 to 800 feet of many wells in the Floridan aquifer system is frequently "open-hole" or uncased. Casing diameters range from 2 to 24 inches. We1ls drilled since 1981 are generally 8 to 12 inches in diameter. Casings are made of steel, black iron, or plastic. Corrosion of metal well casings have caused many older wells to fail, so the use of plastic casing has become more prevalent in recent years. Burns (1983, p. 30) reports that in Lee County (southwest Florida) the life expectancy of steel-cased we11s is 20 to 25 years, and that the corrosion of steel casing is most intensive at the upper part of the surficial aquifer system. As mentioned previously, corroded-through well casings could cause intrusion of water from the Floridan aquifer system into the surficial aquifer system.

More than 90 percent of the inventoried wells in the Floridan aquifer system are used for irrigation. Twelve wells are used as a source of water for reverse osmosis treatment for public-water supply. The city of Vero Beach blends water from two wells in the Floridan with water from the surficial aquifer system for public supply. 
Few wells are equipped with pumps because water levels of most wells in the Floridan aquifer system stand above land surface. Water from the wells would discharge freely if not valved shut. Wells generally flow at sufficient rates to supply needed yields. In this report, wells that discharge freely are termed "flowing wells." When valved shut, flowing wells are termed "shut-in."

\section{Potentiometric Surface}

The potentiometric surface of the Upper Floridan aquifer fluctuates in response to changes in rates of recharge and rates of discharge. The major components that cause water-surface fluctuations are rainfall, pumpage, and, near the coast, tidal changes. Generally, short-term components are superimposed on long-term changes in the potentiometric surface of the Upper Floridan aquifer. Pumpage and rainfall can cause long- and short-term changes in the potentiometric surface.

The regional configuration of the potentiometric surface of the Upper Floridan aquifer in May 1981 is shown in figure 14. In Indian River County, the direction of water movement in the Upper Floridan aquifer is mainly eastward. Figures 43 and 44 show the potentiometric surface of the Upper Floridan aquifer in the county for May 1981 and May 1983. Comparison of the May 1981 potentiometric surface map (reflecting the 1980-81 drought) and the May 1983 map (reflecting above-average rainfall for 1982-83) shows that the potentiometric surface generally ranged 2 to 4 feet lower in May 1981 than in May 1983. The mound shown on the potentiometric surface in May 1981 (fig. 43) is probably residual from the previously high levels.

In the recharge area of the Floridan in Indian River County on the Lake Wales Ridge (fig. 14), September is normally the last month of the wet season and May is the last month of the dry season. Generally, the Upper Floridan aquifer is most stressed by pumping in May because, by then, the dry season has extended for about 7 months, and agricultural irrigation is heaviest. The potentiometric surface in May generally ranges in altitude from about 30 feet along the coastline to about 40 feet near the western county line. The depressions in the potentiometric surface in the eastern half of the county, as shown by the May 1983 potentiometric surface (fig. 44), reflect pumping stress from irrigation. In Indian River County, potentiometric contours generally shift slightly eastward toward the Atlantic Ocean between May and September because of the recharge from summer (wet season) rains and the associated curtailed local irrigation pumping.

\section{Water Levels}

\section{General}

Water levels in wells in discharge areas typically rise as the depth of penetration of the well increases, but few data are available to quantify differences in the levels in shallow and deeply penetrating wells in the Floridan aquifer system in the county. Geraghty and Miller, Inc. (1981b) reported that the water level of a well that is 901 feet deep (wel1 41F) was 3.5 feet higher in December 1980 than that in a nearby we11 740 feet deep (well 37F). Water levels of wells cased into the Lower Floridan aquifer are probably at least several feet higher in altitude than the levels of wells 


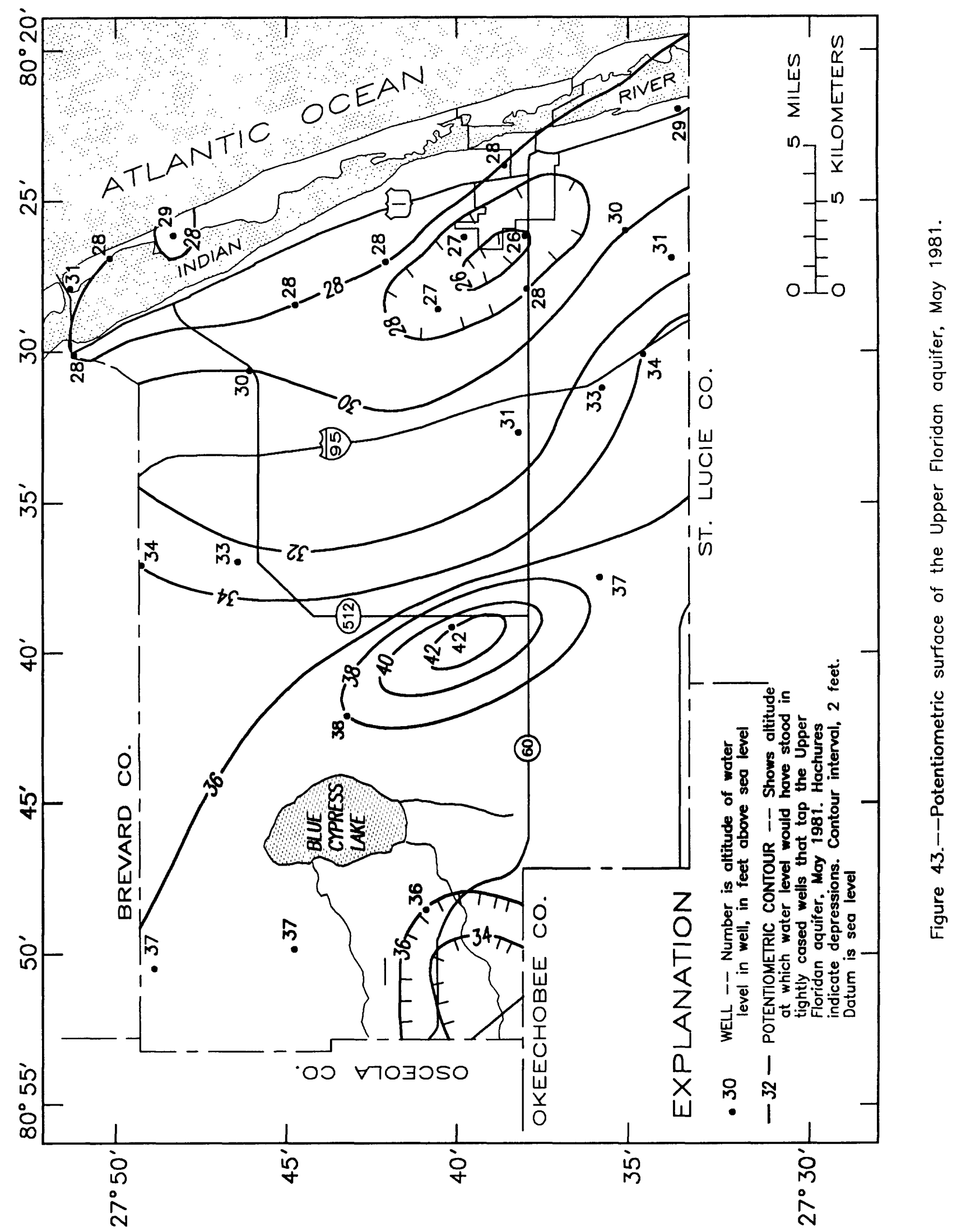




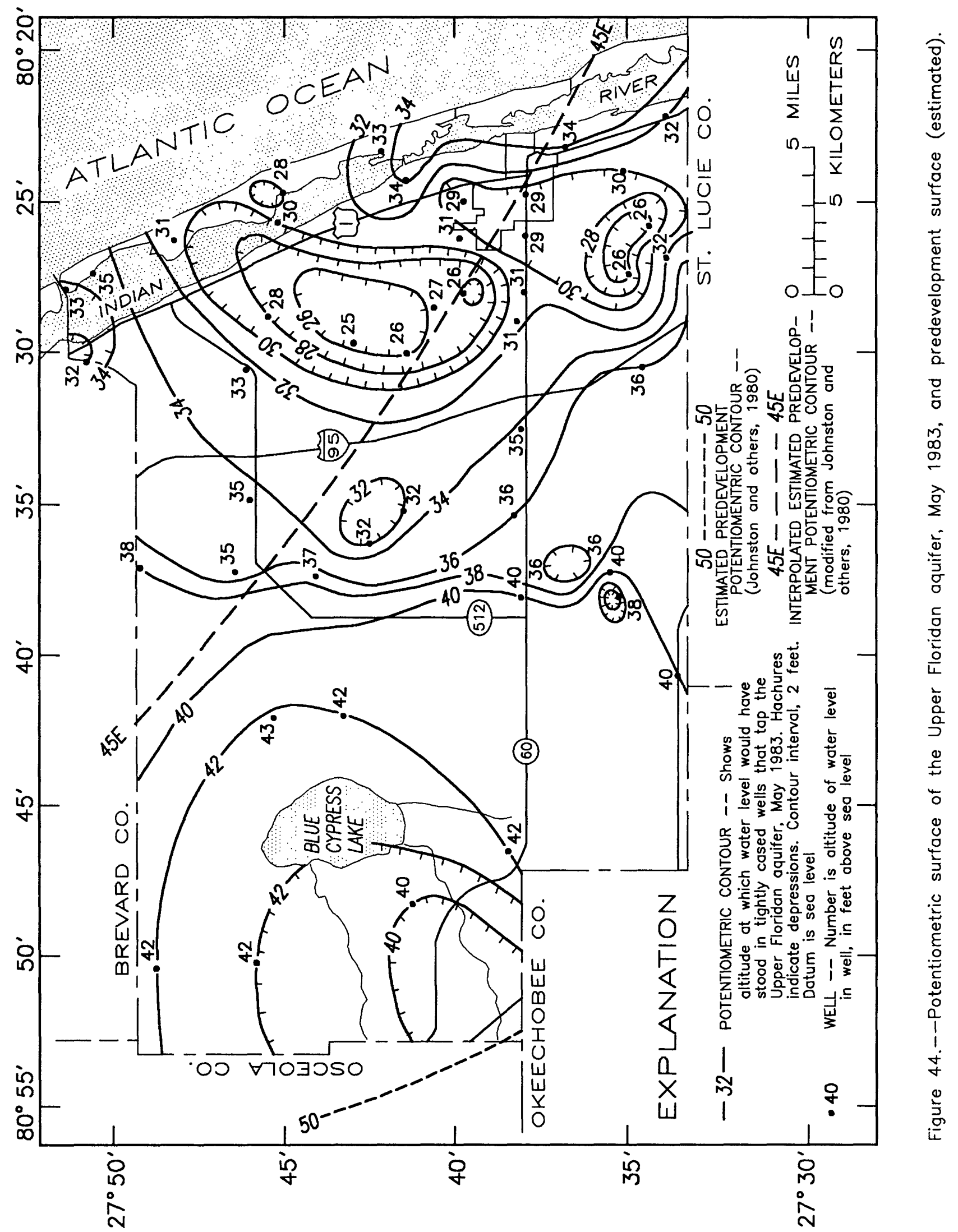


in the Upper Floridan aquifer. However, most wells in the Upper and Lower Floridan aquifers are cased only into the Hawthorn Formation; so water levels, particularly in the Lower Floridan, are resultant combination heads.

The hydrographs of two long-term observation wells completed in the Floridan aquifer system illustrate water-level fluctuations in a heavily irrigated area (wel1 $23 \mathrm{~F}$ in fig. 45) and the fluctuations in an area little affected by pumping (well $168 \mathrm{~F}$ in fig. 46). (See fig. 47 for locations.) A comparison of the hydrographs and analysis of water-level data collected for compilation of biannual potentiometric surface maps show that September water levels generally range from 2 to 5 feet higher than May levels. However, in heavily pumped areas, water levels may decline as much as 15 feet between September and May if rainfall is deficient. The rainfall deficiencies of about 12 inches in 1980 and about 7 inches in 1981 , and the probable effects of regional pumping, resulted in a record low May 1981 water level altitude (36.67 feet) in well $168 \mathrm{~F}$ (fig. 46). Water levels in many other wells in the county also fell to record lows in May 1981.

\section{Water-Leve1 Trends}

In Indian River County, long-term trends of water levels in the Floridan aquifer system are due to prolonged change in recharge and to water-use activities such as pumping for irrigation and public supply (development). Long-term trends due to development are difficult to ascertain because trends may be masked by the effect of variations in recharge. Water levels in the mostly undeveloped western part of the county are about 8 to 10 feet lower than those estimated for predevelopment time in the early $1930^{\prime} s$.

Water-level data in table 7 shows that levels in the Floridan aquifer system in eastern Indian River County have declined about 16 to 24 feet in the 50-year period 1934 to 1984. The greatest decline occurred in the period 1934 to 1971. Since 1971, levels have apparently stabilized. At Avon Park in Highlands County, which is in a recharge area of the Floridan aquifer system, water levels show a similar, but greater, pattern of decline. There, water levels declined about 28 feet between 1934 and 1978 . The hydrograph of well $168 \mathrm{~F}$ ( $\mathrm{fig}$. 46) indicates no overall trend in the period 1976 to 1985. Brown and Reece (1979, pl. 3) reported no significant upward or downward trend of water levels in the Floridan aquifer system in the period 1970 to 1977 in adjacent St. Lucie County. The hydrograph of well 23F (fig. 45), in the Indian River Water Control District, suggests a downward trend from 1959 to 1971 and possibly an upward trend since 1972 .

In the future, water levels in the Floridan aquifer system may decline in the Fellsmere area because of added stress on the system by planned expansion of agricultural irrigation. Water levels may also decline in the vicinity of the county's 0slo Road reverse osmosis plant as pumpage there for public supply increases. However, in some areas of the county water levels in the Floridan aquifer system probably will rise because of reduced irrigation pumpage due to urbanization. In the Indian River Water Control District and the Wabasso Beach area (fig. 1), for example, water levels will probably rise because irrigation pumpage will continue to decline as more citrus groves are replaced with urban-type developments that use publicsupply systems. The amount of water used for public-water supply is not 


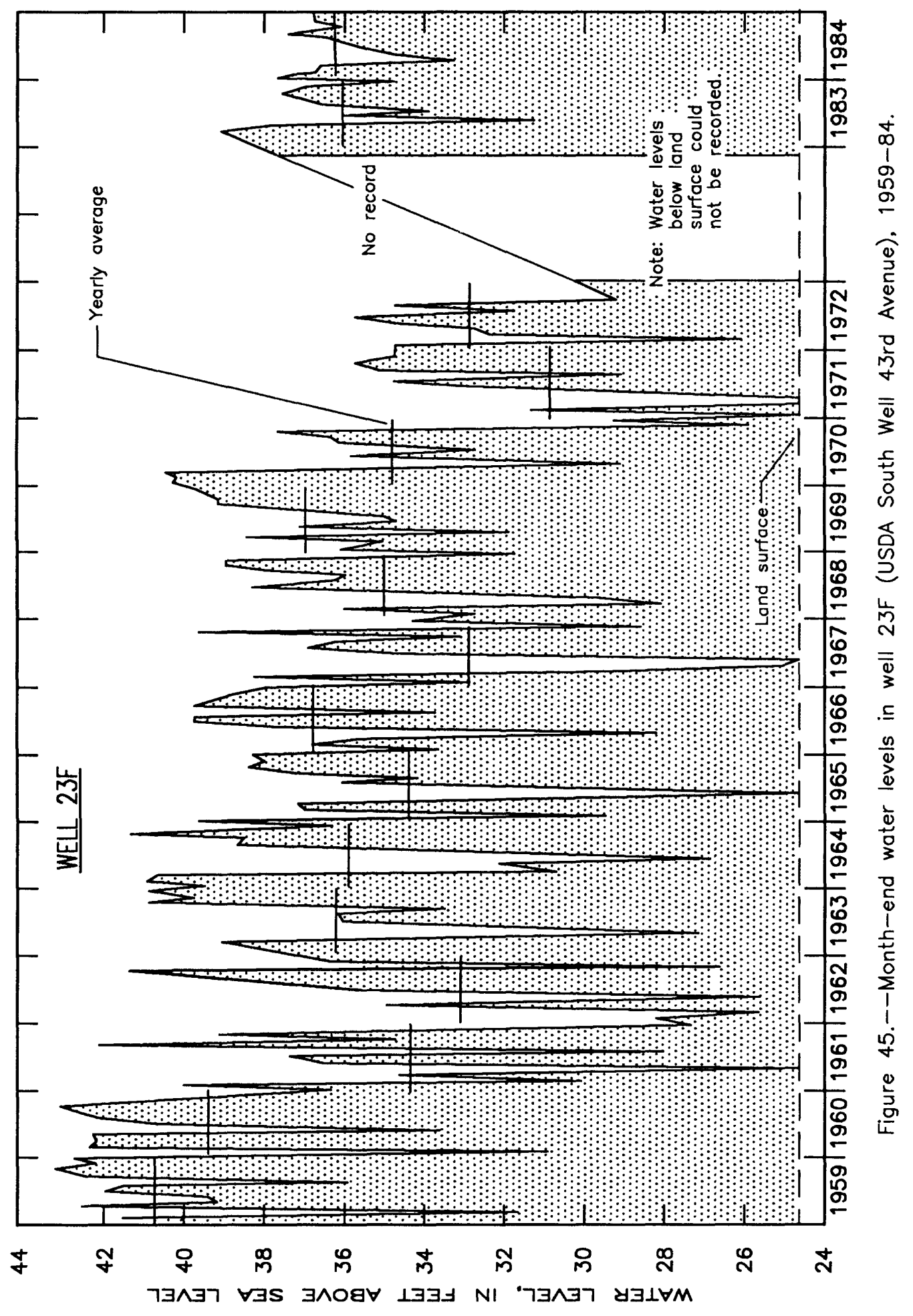


expected to equal the amount previously used for irrigation in the foreseeable future; so, in those places, water levels will probably rise unless additional demands are placed on the aquifer.

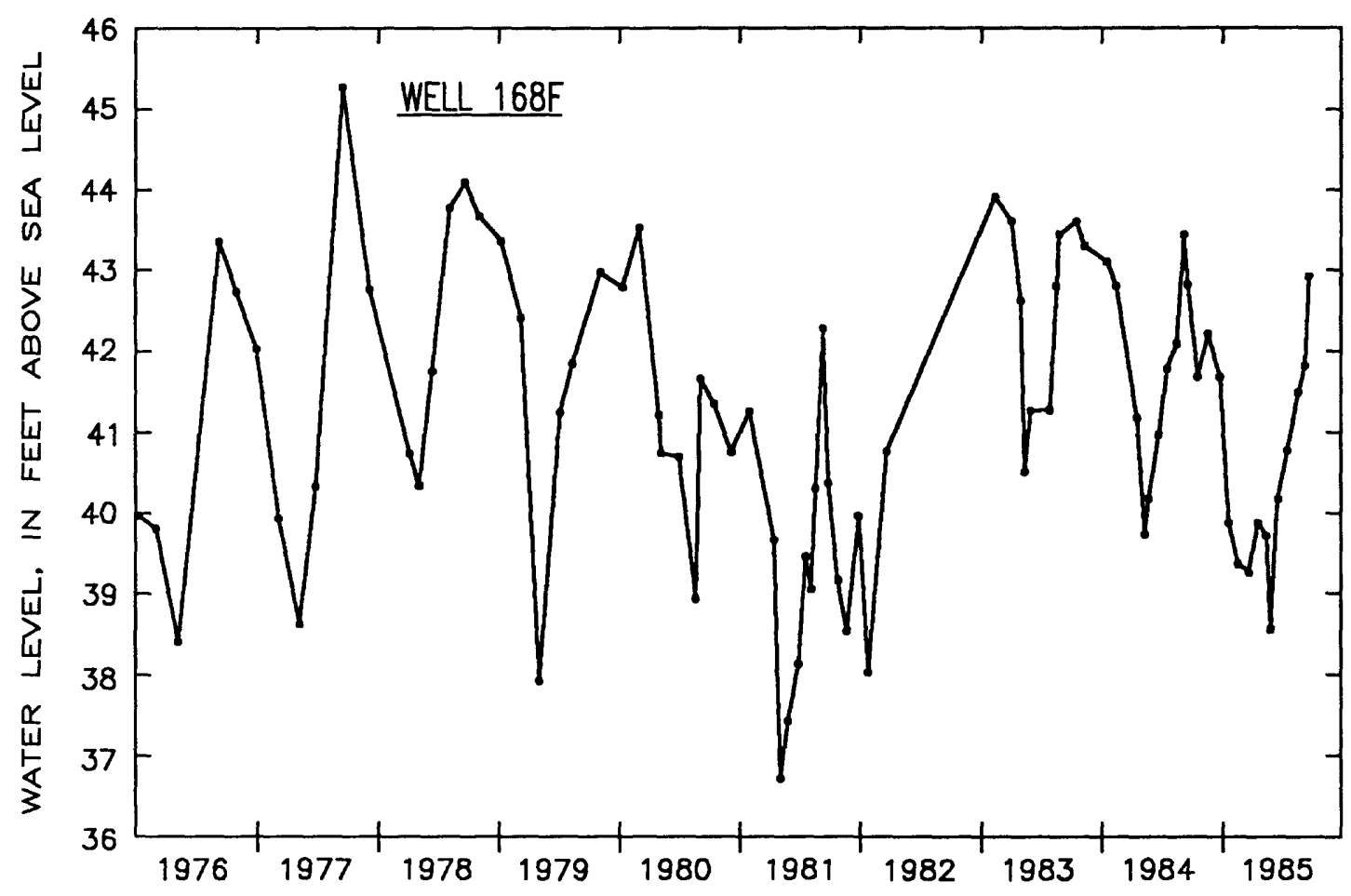

Figure 46.--Water level in well 168F (USGS Observation Well IR 189), 1976-85.

\section{Water Quality}

General

Most of the water that recharges the Floridan aquifer system in Indian River County originates as rainfall on the Lake Wales Ridge, to the west, in Polk County (fig. 14). The mineralization of the water increases as it moves eastward toward the coast and by the time it reaches the discharge area that includes Indian River County, the water quality in the Floridan aquifer system contains relatively high concentrations of dissolved-solids. Saline water ranging from slightly saline to brine is present at varying depths beneath the entire county. In places, water in the Upper Floridan aquifer is fresh, particularly in the upper part. Salinity increases with depth and is a function of flushing out of the ancient seawater trapped in the sediments during an earlier geologic time (Sprinkle, 1982). Water movement is generally sluggish (Miller, 1986, p. B63) in the Lower Floridan aquifer where little flushing has occurred and the water is briney. 


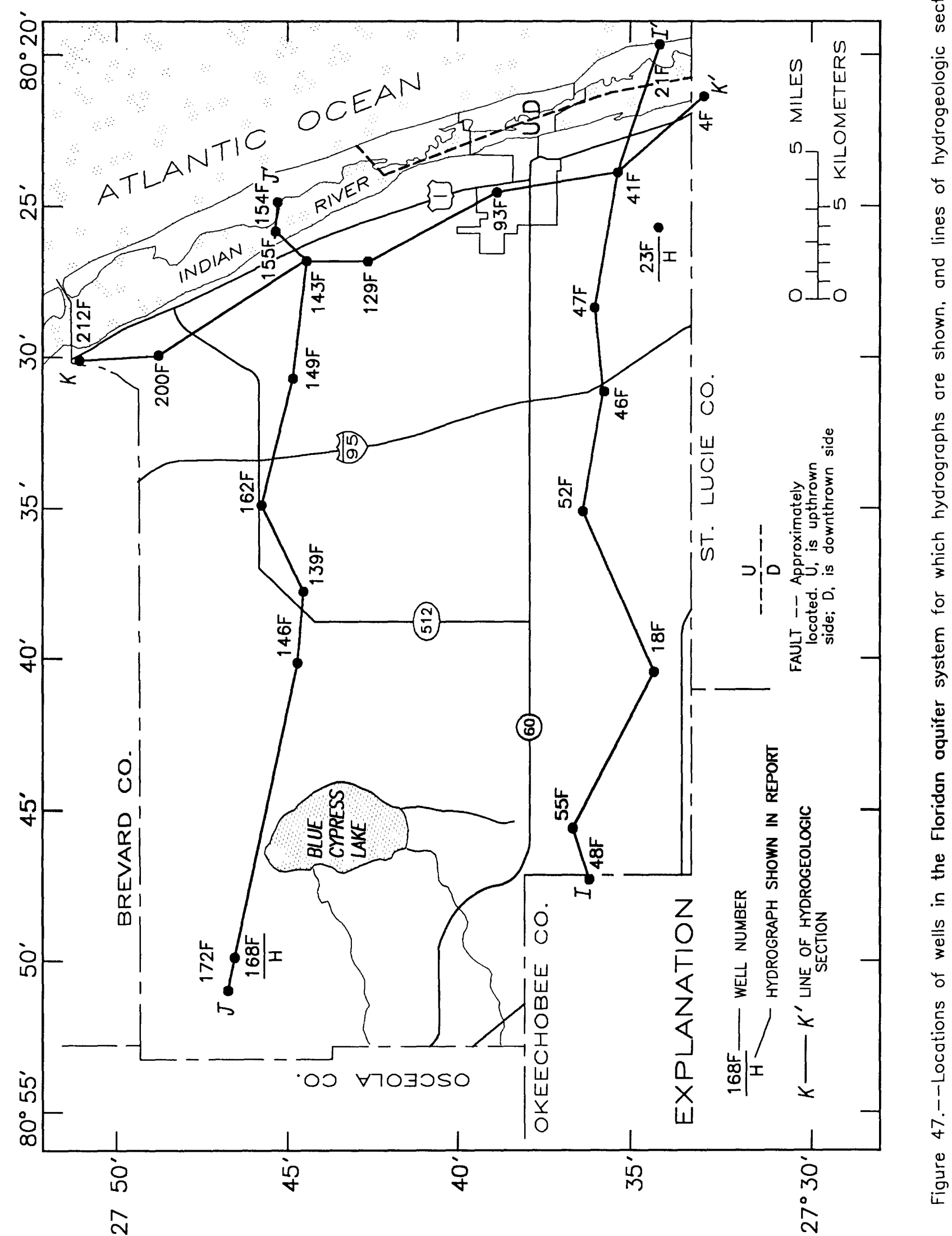


Table 7.--Ground-water levels at selected sites in Indian River and Highlands Counties, $11934,1951,1971$, and 1984

[Water levels are in feet above sea level]

\begin{tabular}{|c|c|c|c|c|}
\hline Year & Vero Beach & Fellsmere & Sebastion & $\begin{array}{c}\text { Avon Park } \\
\text { (Highlands Co.) }\end{array}$ \\
\hline 1934 & $48(\mathrm{Feb})^{1}$ & 55 (Aug) $^{1}$ & 46 (Aug) $^{1}$ & $105(\mathrm{Feb})^{2}$ \\
\hline 1951 & 40 (Oct) & 48 (Oct) & $37(0 c t)$ & 92 (Apr) \\
\hline 1971 & 28 (May) & 34 (May) & 30 (May) & - - \\
\hline 1984 & 30 (May) & 31 (May) & 30 (May) & 78 (May) \\
\hline
\end{tabular}

${ }^{1}$ From Stringfield (1936).

2Estimated from nearby measurements made in Highlands and Polk Counties.

The water quality of a well completed in the Floridan aquifer system is a composite of the quality of water in the various producing zones penetrated by the open borehole. Water-quality data from Bermes (1958), Crain and others (1975), and unpublished data indicate that water from the Floridan aquifer system is generally hard and relatively high in dissolved solids. Most water is of the sodium chloride type. Chloride, bicarbonate, and sulfate are the major anions, and sodium, calcium, and magnesium the major cations. Potassium and strontium are common minor constituents. Trace amounts of other ions are also present. The distribution and values of salinity as measured by dissolved-solids concentrations are similar to chloride concentrations in the Floridan aquifer system. Concentrations of chloride and dissolved solids commonly exceed the Florida Department of Environmental Regulation (1982) maximum contaminant level for public drinking water systems ( $250 \mathrm{mg} / \mathrm{L}$ for chloride and $500 \mathrm{mg} / \mathrm{L}$ for dissolved solids where alternate supplies of lower concentration are avallable).

Lateral intrusion of saltwater from the Indian River or the Atlantic Ocean into the Floridan aquifer system is not possible under current conditions because of the aquifer's high head along the coast (at about the 30-foot altitude), and because the freshwater-saltwater interface is a considerable distance offshore. The high Floridan heads, responsible for discharging conditions throughout the county, also prevent pollutants on the land surface from moving downward into the Floridan. Pollutants could be introduced into the aquifer from recharge areas, mostly outside the county, or heavy pumping could cause local upconing of very saline water from depth.

\section{Variations of Chloride Concentration in We1ls}

Sprinkle (1982) reports that significant chemical differences may be found in the water from nearby wells, or from the same well from year to year, in the area that includes Indian River County. Therefore, recognition of a trend in chloride concentration in the water from individual wells is difficult to ascertain. An example is the water from well 20F (fig. 48) in which chloride concentrations of water from well 20F (fig. 48) ranged from 
CONTINUOUSLY FLOWING WELLS
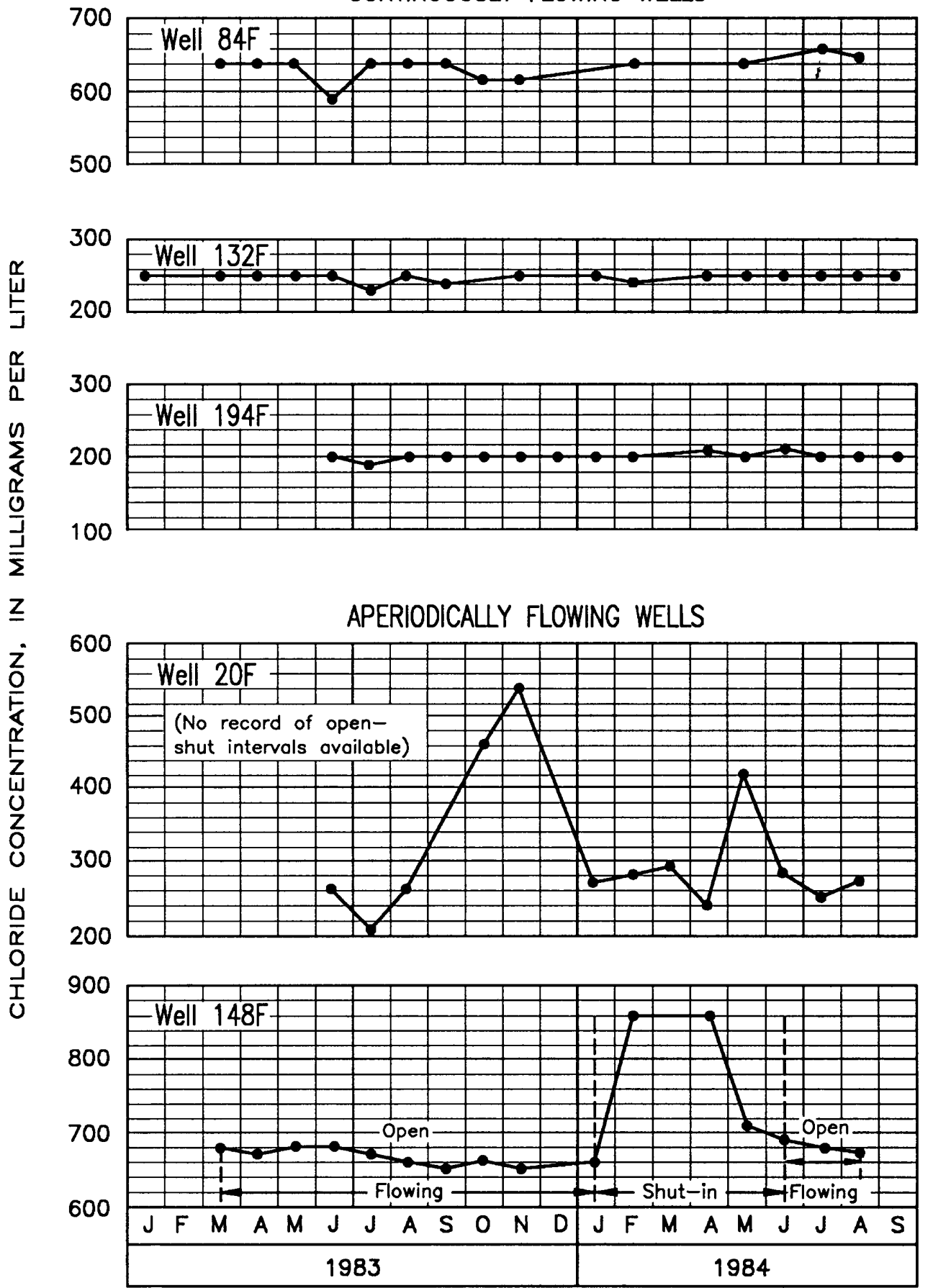

Figure 48.--Chloride concentrations in water from continuously flowing and aperiodically flowing wells. 
210 to $540 \mathrm{mg} / \mathrm{L}$ during a 14 -month sampling period. Fluctuations of chloride concentration in the water from a well may be related to head changes and changes in flow contributions of producing zones. Also, pumping during the dry season could lower heads enough to cause some upconing of saline water-particularly in wells completed in the Lower Floridan aquifer. Variations in the chloride concentration of water from a well sampled periodically may also be due to sampling technique or to the geohydrologic characteristics of the well.

Water-quality sampling techniques are designed to provide data that are representative of water in the aquifer. For this study, samples were taken from either shut-in or actively flowing wells. Samples from shut-in wells were taken at the wellhead by opening a valve and allowing water from the well to flow. Samples from flowing wells were taken from the discharge pipe or from a spigot on the well. Most sampling was done periodically-generally for chloride concentration determinations.

An important factor in sampling is to ensure that only native aquifer water is sampled. Barraclough (1962, p. 75) reports that in Seminole County (central Florida), the most important index of chloride concentration in water from some flowing wells is not changes in water level but the period the well is allowed to flow prior to sampling. Chloride concentrations of water from an observation well in Seminole County ranged from $65 \mathrm{mg} / \mathrm{L}$ at a flow period of 5 minutes to $290 \mathrm{mg} / \mathrm{L}$ for flows longer than 5 minutes.

For this study, prior to sampling, a shut-in well was allowed to discharge at least long enough to evacuate and replace the water stored in the wellbore with fresh formation water. For example, for an 8-inch-diameter we11 1,000 feet deep that discharges $500 \mathrm{gals} / \mathrm{min}$, the required time is about 5 minutes. Wellhead discharge waters that have attained a steady temperature or specific conductance generally indicate that the wellbore has been completely flushed.

Most we11s that tap the Floridan aquifer system in Indian River County are periodically used during dry weather periods and freeze periods. When not in use, the wells are shut-in to prevent needless discharge. Chloride concentrations of water in these periodically shut-in wells appear to vary more than the concentration in we11s that flow continuously.

Periodically, open wells may allow high chloride concentration water in a deep-producing zone of the Floridan aquifer system to invade an upper, better quality zone during shut-in periods. As mentioned previously, deepproducing zones in Floridan aquifer system have higher heads than the shallow producing zones. Many irrigation wells tap the Lower Floridan aquifer but are cased only to about the middle of the Hawthorn Formation. This can allow the higher head, more mineralized, water from a producing zone in the Lower Floridan aquifer to move into and contaminate a better quality producing zone in the Upper Floridan aquifer. Figure 49 illustrates the hypothetical paths of water movement in a periodically open well that penetrates the Upper and Lower Floridan aquifer. Head differentials indicate that a significant potential exists for water from the Floridan aquifer system to intrude into the surficial aquifer system through a break in a casing ( $\mathrm{fig}$. 49). 


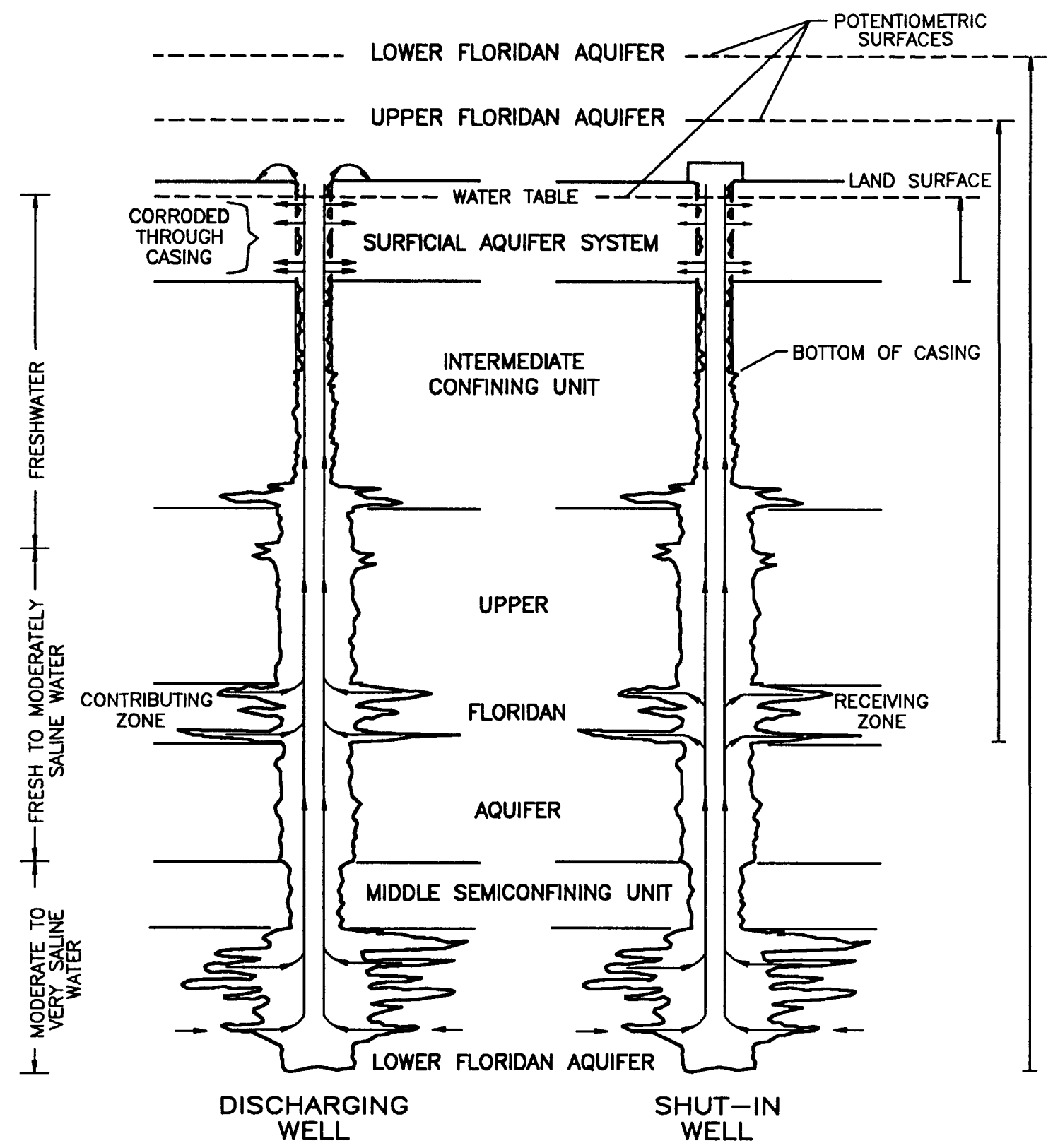

Figure 49.--Hypothetical paths of ground-water movement in wells that penetrate both the Upper and Lower Floridan aquifer. 
The volume and quality of water that moves into or intrudes a receiving zone (fig. 49) in a shut-in or flowing well is directly related to head differentials, transmissivities, water density, the water quality of the producing zones, and to time. If a shut-in well is allowed to flow, the time required to evacuate the intruded zone in the Floridan will be longer than the time the well was shut-in. This is due to blending of the water in the intruded zone and the hydraulics of flow in the zone.

The plot of the chloride concentrations in water from well $148 \mathrm{~F}$ (fig. 48) illustrates the effect of shutting-in a flowing well for a period of time. Prior to being shut-in, chloride concentrations ranged from 650 to $680 \mathrm{mg} / \mathrm{L}$. But after the well was shut-in (January 1984), the chloride concentration began to rise, reaching $860 \mathrm{mg} / \mathrm{L}$ by mid-February. The chloride concentration remained at $860 \mathrm{mg} / \mathrm{L}$ for several months with the well shut-in. After the well was opened and allowed to flow, the chloride concentration declined rapidly to $710 \mathrm{mg} / \mathrm{L}$ and continued to decline with time thereafter until it reached the previous concentration of open conditions. The decline in chloride concentration is probably due to the slow release of mixed-quality water from an upper-producing zone that had been intruded by relatively high chloride water from a lower zone.

Many wells that flow continuously appear to reach an equilibrium of hydrologic conditions in which temporal and recharge-discharge changes have little influence on the chloride concentration of water in the wells. Chloride concentrations in water from flowing wells $84 \mathrm{~F}, 132 \mathrm{~F}$, and $194 \mathrm{~F}$ (fig. 48) show little fluctuation though their period of record covers several seasons and include seasonal variations in precipitation and pumpage. Water from wells periodically open and wells recently drilled may exhibit considerable variations in chloride concentration because equilibrium conditions have not been attained. (See well 20F in fig. 48, a relatively new well, for example.) Chloride concentrations of the water in recently drilled wells may often increase with time and concomitant decline in head. The period of time required for a well to reach water-quality constancy may vary with the hydrologic environment of the individual well and its use and could be years.

\section{Distribution of Chlorides}

Chloride concentrations of water in the Floridan aquifer system may vary considerably both areally and vertically as well as temporally. Predictions of chloride concentration at a particular location cannot be made with certainty, but generalizations can be made based on patterns of occurrence.

Figures 50 and 51 are highly generalized maps that show the distribution of chloride concentrations of water from wells that tap the Upper Floridan aquifer and both the Upper and Lower Floridan aquifers, respectively. Most of the data used to compile the maps were collected in 1983--some data are from the 1984-85 period. The wells that tap both the Upper and Lower Floridan aquifers probably derive most of their yield from the Lower Floridan which generally contains more highly mineralized water. Chloride concentrations generally increase slightly with depth in the Upper Floridan aquifer but may increase rapidly with depth in the Lower Floridan. Therefore, the concentrations shown for water mostly from the Lower Floridan 


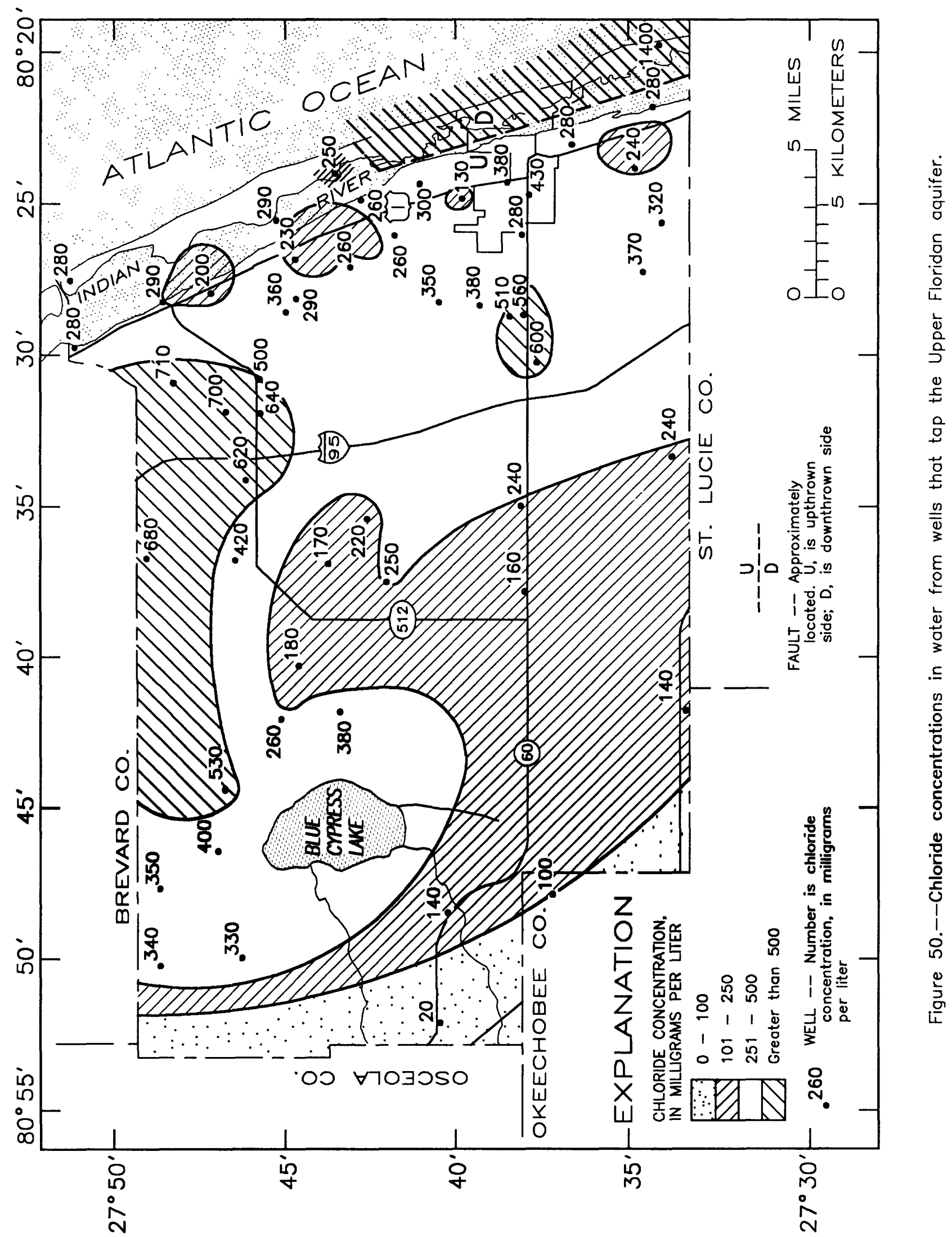




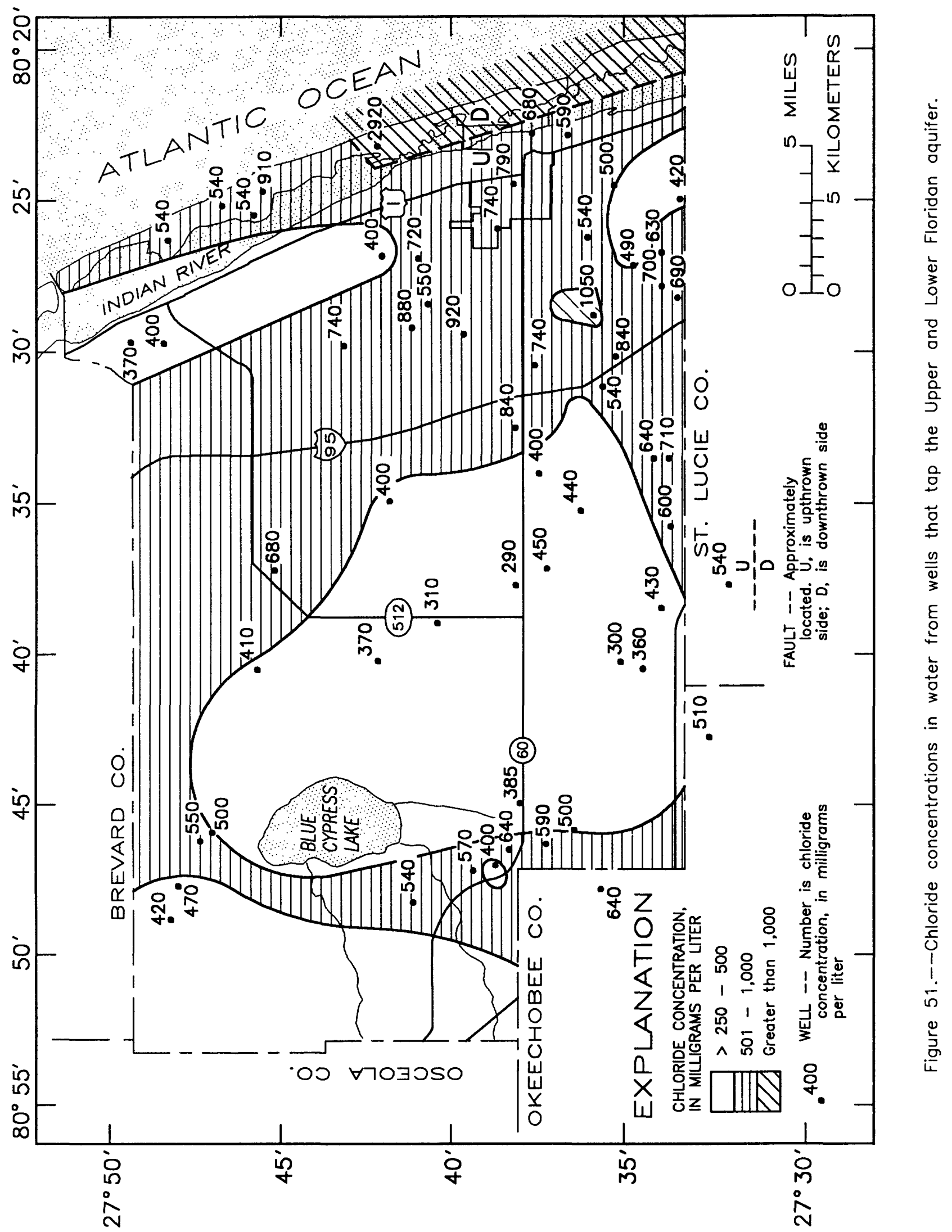


aquifer are more variable than for water in the Upper Floridan aquifer because differences in well depths may cause large differences in chloride concentration. The highest concentrations for both aquifers are found on the east (downthrown) side of the fault along the Indian River.

Chloride concentrations in water from wells that yield mostly from the Upper Floridan aquifer range from 20 to about $1,400 \mathrm{mg} / \mathrm{L}$. The lowest concentrations are in the area of the Talbot terrace (figs. 2 and 50). Concentrations less than $250 \mathrm{mg} / \mathrm{L}$ are found in about half the county-generally in the western, southwestern, and central part. Areas of less than $250 \mathrm{mg} / \mathrm{L}$ concentration occur as patches oriented parallel to the coast along the trace of the Atlantic Coastal Ridge (figs. 2 and 50). These patches may be pockets of freshwater that were trapped in the aquifer during a low stand of the sea during the Pleistocene Epoch (Tibbals, in press), or as theorized by Crain and others (1975, p. 49), may represent areas of recharge to the Upper Floridan aquifer. The highest concentration of chloride in water from the Upper Floridan is between the Talbot terrace and the Atlantic Coastal Ridge in the northern part of the county (figs. 2 and 50). The high chloride concentrations found in water from some Upper Floridan aquifer wells may be in those places where the underlying middle semiconfining unit is relatively permeable, thin, or breached. There, pumping could more readily cause upconing of high chloride concentration water from the Lower Floridan aquifer into the Upper Floridan aquifer.

Chloride concentrations in water from wells that yield mostly from the Lower Floridan aquifer range from 290 to $2,920 \mathrm{mg} / \mathrm{L}$. In the eastern half of the county, water from these wells generally have chloride concentrations higher than $500 \mathrm{mg} / \mathrm{L}$. Chloride concentrations ranging from 700 to 1,050 $\mathrm{mg} / \mathrm{L}$ occur in a large area between the Atlantic Coasta1 Ridge and the TenMile Ridge (fig. 51). Concentrations of $400 \mathrm{mg} / \mathrm{L}$ or less occur as a narrow band along the trace of the Atlantic Coastal Ridge in the northern half of the county and a northeast oriented band of $300 \mathrm{mg} / \mathrm{L}$ or less is centered at the junction of State Highways 60 and 512 .

The high chloride concentrations of $910 \mathrm{mg} / \mathrm{L}$ in water from well $154 \mathrm{~F}$ (near Wabasso Beach) and $1,050 \mathrm{mg} / \mathrm{L}$ in well $47 \mathrm{~F}$ (south of State Highway 60 and east of I-95, figs. 1 and 51) may have been caused by their relatively heavy pumping and their greater depth than nearby wells.

\section{Trends in Chloride Concentrations}

The recognition of any time trend in chloride concentrations of water from wells is essential to management of the county's water resources. Figure 52 shows the chloride concentrations of water from 26 wells in the Floridan aquifer system. These same wells were sampled at three time intervals during the period 1951-84. The following table gives the average chloride concentrations for the time intervals.

Sampling period

$1951-52$

$1968-71$

$1983-84$

\section{Average chloride concentration (mg/L)}

369

424 (increase of 15 percent)

451 (increase of 6 percent from 1968-71 and 22 percent from 1951-52) 


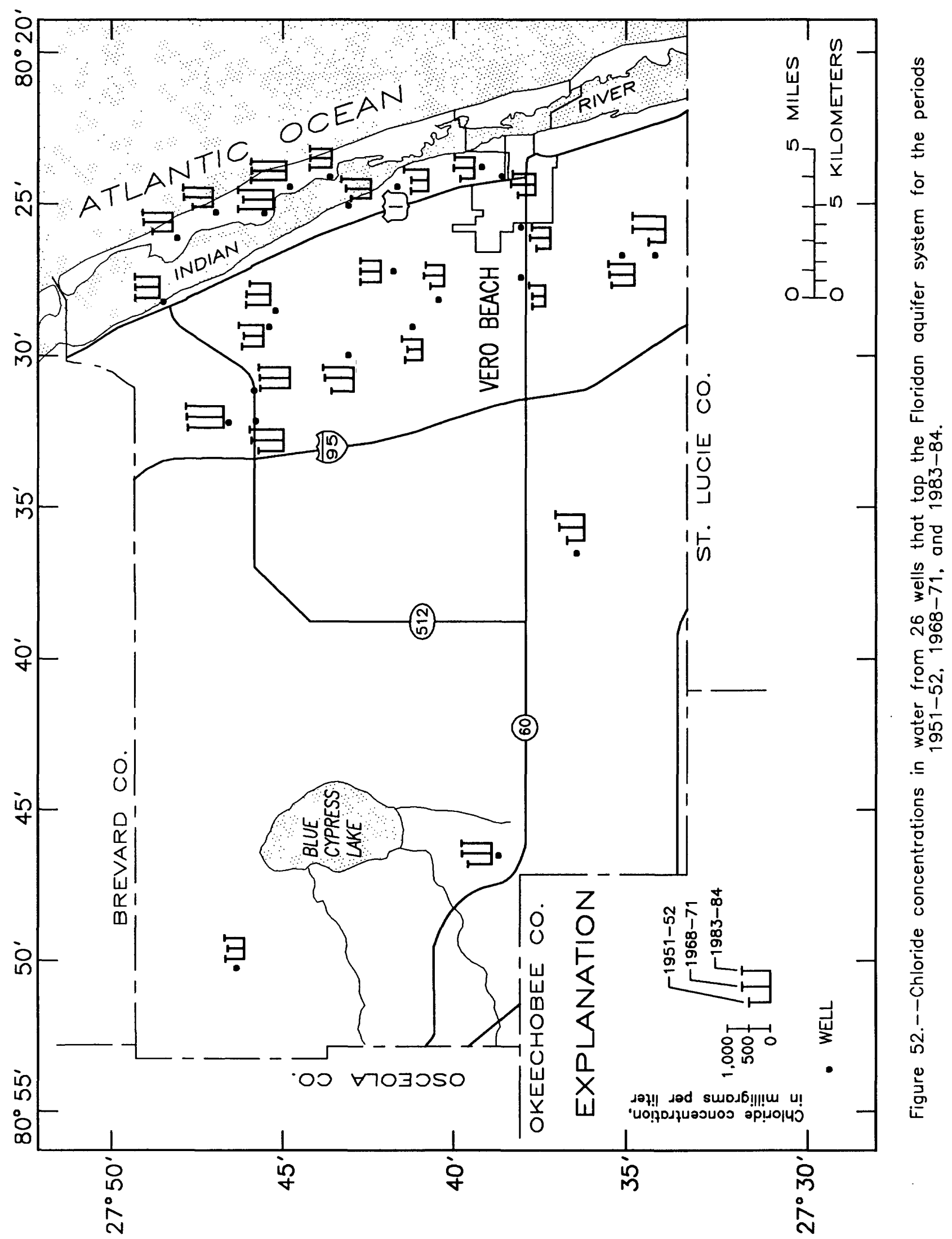


Chloride concentrations increased more than 10 percent in 11 of the 26 wells between the period 1951-52 and 1968-71, but concentrations increased more than 10 percent in only 5 wells between the period 1968-71 and 1983-84.

Crain and others (1975, p. 53) compared chloride concentrations of water from wells in the Floridan sampled in 1951-52 to that of samples collected in 1968-71 and found a small increase in chlorides in the eastern part of the county north of Winter Beach and a small decrease in chlorides south of Winter Beach. Data obtained for this study in 1983-84 shows that chloride concentrations increased about 25 percent in T33S (Township 33 South), R39E (Range 39 East), south of Vero Beach, between the periods 1951-52 and 1983-84. (See fig. 1 for Township and Range locations.) In T32S, R39E--the Vero Beach area--the increase was about 18 percent. In T31S, R39E--the Sebastian area--the chloride concentration decreased by 11 percent. The decrease may be due to the plugging of unused flowing we11s. The overall increase in chloride concentration in the three townships was only 9 percent between the 1951-52 and the 1983-84 period. Average chloride concentrations in the townships for the three sampling periods are given in the following table.

\begin{tabular}{|c|c|c|c|c|c|c|}
\hline \multirow[b]{2}{*}{$\begin{array}{l}\text { Township } \\
\text { and } \\
\text { range }\end{array}$} & \multicolumn{2}{|c|}{$1951-52$} & \multicolumn{2}{|c|}{$1968-71$} & \multicolumn{2}{|c|}{$1983-84$} \\
\hline & $\begin{array}{l}\text { Number } \\
\text { of we11s } \\
\text { sampled }\end{array}$ & $\begin{array}{l}\text { Average } \\
\text { chloride } \\
\text { (mg/L) }\end{array}$ & $\begin{array}{l}\text { Number } \\
\text { of we1ls } \\
\text { sampled }\end{array}$ & $\begin{array}{c}\text { Average } \\
\text { chloride } \\
\text { (mg/L) }\end{array}$ & $\begin{array}{l}\text { Number } \\
\text { of we11s } \\
\text { sampled }\end{array}$ & $\begin{array}{c}\text { Average } \\
\text { chloride } \\
\text { (mg/L) }\end{array}$ \\
\hline $\begin{array}{l}\text { T31S, R39E } \\
\text { T32S, R39E } \\
\text { T33S, R39E } \\
\text { Tota1 } \\
\text { Average of } \\
\text { a11 samples }\end{array}$ & $\begin{array}{l}45 \\
21 \\
23 \\
89\end{array}$ & $\begin{array}{l}488 \\
313 \\
424 \\
--\end{array}$ & $\begin{array}{l}13 \\
16 \\
14 \\
43\end{array}$ & $\begin{array}{l}462 \\
334 \\
450 \\
-\end{array}$ & $\begin{array}{l}23 \\
17 \\
18 \\
58\end{array}$ & $\begin{array}{l}436 \\
370 \\
529 \\
--.\end{array}$ \\
\hline
\end{tabular}

Data from four Floridan aquifer system wells in a grove at Wabasso Beach show no increase in chloride concentration from the 1940's to 1984. However, the chloride concentration of water from wel1 $177 \mathrm{~F}$, completed in the Lower Floridan aquifer, rose from $378 \mathrm{mg} / \mathrm{L}$ in 1951 to $540 \mathrm{mg} / \mathrm{L}$ in 1983 . The chloride concentration in 1969 was $535 \mathrm{mg} / \mathrm{L}$.

Chloride concentrations of water in the Upper Floridan aquifer are increasing in the Vero Beach area. In the city well field, the chloride concentration of water from we $1194 \mathrm{~F}$ increased from $285 \mathrm{mg} / \mathrm{L}$ in November 1976 to $384 \mathrm{mg} / \mathrm{L}$ in May 1985 (35 percent increase). Chloride concentrations of water from well $93 \mathrm{~F}$ increased from $300 \mathrm{mg} / \mathrm{L}$ in April 1979 to $476 \mathrm{mg} / \mathrm{L}$ in May 1985 (59 percent increase). Except for 1950, the following table shows a progressive upward trend in chloride concentration since 1921 in water from well $73 \mathrm{~F}$ at the old Vero Beach Power Plant.

\begin{tabular}{|c|c|c|c|c|c|c|c|}
\hline Year & & & 1924 & 1949 & 1950 & 1951 & 1983 \\
\hline $\begin{array}{l}\text { Month } \\
\text { Ch1oride (mg/L) }\end{array}$ & $\begin{array}{l}\text { Aug } \\
270 \\
\end{array}$ & $\begin{array}{l}\text { Oct. } \\
291\end{array}$ & $\begin{array}{r}-- \\
455 \\
\end{array}$ & $\begin{array}{l}\text { Oct. } \\
625\end{array}$ & $\begin{array}{l}\mathrm{J} \text { an. } \\
550\end{array}$ & $\begin{array}{l}\text { Dec. } \\
630\end{array}$ & $\begin{array}{l}\text { July } \\
790\end{array}$ \\
\hline
\end{tabular}


Well $73 \mathrm{~F}$ has been out of service and shut-in for many years. High chloride concentration water from the lower part of the well may have substantially infiltrated the upper, better-quality zones.

On a countywide basis, the chloride concentrations of water from wells in the Floridan aquifer system have apparently not changed significantly in the 15-year period 1968 to 1983. Brown and Reece (1979, p1. 6) report that chloride concentrations of water from wells in the Floridan aquifer system did not change significantly during the 20-year period 1957-77 in the area that includes St. Lucie County--the adjacent county south of Indian River. A few localities and some individual wells have shown increases in chloride concentration, but the increases probably reflect a local condition rather than a general trend.

\section{Effect of Irrigation Water from the Floridan Aquifer System on the Quality of Canal Water}

Crain and others (1975, p. 53) reported that major canals that drain the eastern part of the county had similar water quality. Large quantities of relatively poor quality irrigation water from wells in the Floridan aquifer system commonly $\mathrm{mix}$ with higher quality surface water and water from the surficial aquifer system in the canals. However, the quality of water present in a canal at a given time varies widely with the relative proportions of rainfall, irrigation water from the Floridan aquifer system, and ground-water contribution from the surficial aquifer system. The variation in water quality, as indicated by specific conductance, was determined for South Canal at 43rd Avenue (fig. 53) from February 1983 to September 1984.

The specific conductance of canal water is generally highest during the dry season (November through June) because flow in the canal consists largely of irrigation water from the Floridan aquifer system. During the wet season, much of the canal water is rainfall and surface runoff, and specific conductance is relatively low.

Figure 53 shows the effects of discharge from Floridan aquifer system wells and rainfall on the water quality of South Canal. The specific conductance of water in the canal generally ranged from 900 to $1,700 \mu \mathrm{S} / \mathrm{cm}$ (about $250 \mathrm{mg} / \mathrm{L}$ and $450 \mathrm{mg} / \mathrm{L}$ chloride, respectively). The specific conductance was lowest $(540 \mu \mathrm{S} / \mathrm{cm}$ ) in October 1983 when the monthly rainfall

totaled a record high 15.58 inches. The highest specific conductance of $2,880 \mu \mathrm{S} / \mathrm{cm}$ (about $850 \mathrm{mg} / \mathrm{L}$ chloride) was in May 1984 following a month with only 1.02 inches of rain. Large quantities of water from the Floridan aquifer system are apparently used for freeze protection of citrus groves. In December 1983, temperatures dropped below freezing for three consecutive days, December 25, 26, and 27. The conductance of canal water was $2,700 \mu \mathrm{S} / \mathrm{cm}$ on the $27 \mathrm{th}$, but declined to $1,120 \mu \mathrm{S} / \mathrm{cm}$ on January $6 \mathrm{th}$. During part of the dry season, generally about November through February, natural requirements for water by citrus trees diminishes as average daily temperatures decline, so little irrigation water is needed. For example, conductances remained comparatively low in November 1983 and January 1984, though rainfall was only 1.58 inches (average is 2.55 inches) and 2.02 inches (average is 2.43 inches), respectively. 


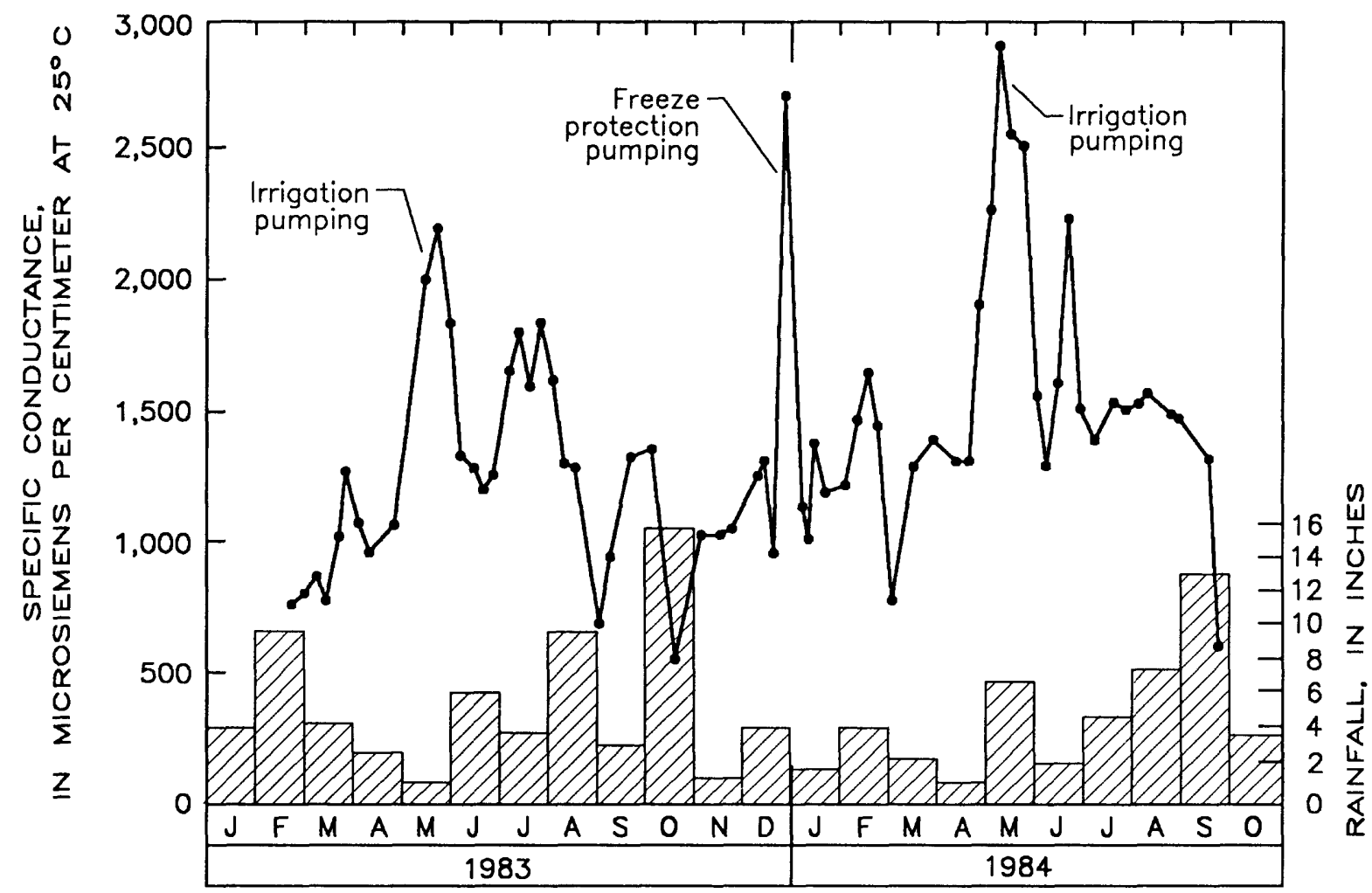

Figure 53.--Specific conductance of water in South Canal at 43rd Avenue and precipitation at Vero Beach.

\section{WATER USE}

\section{Genera1}

The main public-water systems in the county are the cities of Vero Beach and Sebastian, and the county plant on Oslo Road. Figure 54 is a graph of the annual pumpage for Vero Beach, 1954-84. An undetermined amount of water used for irrigation originates from the dewatering of marshland. Large tracts of land previously part of the St. Johns Marsh east and south of Blue Cypress Lake are dewatered to grow citrus. Continuous pumping is needed to lower the near-surface water table enough to allow agriculture. Because dewatering is done throughout the year, including the dry season, the amount of water pumped may be large. Some of the water pumped from dewatering is ultimately used for irrigation. 


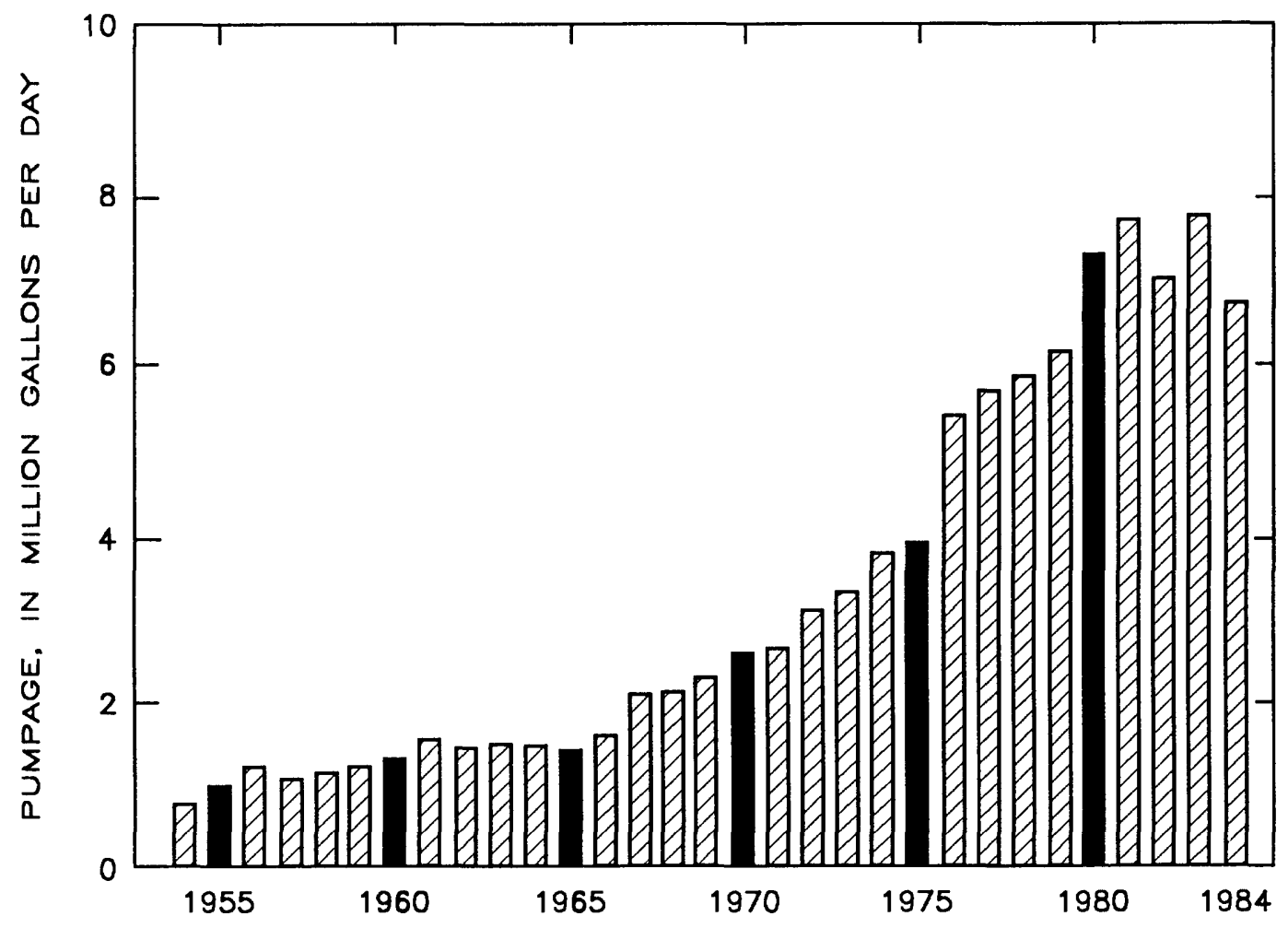

Figure 54.--Annual pumpage by the city of Vero Beach, 1954-84.

The following table gives the estimated water use in Indian River County for 1984.

\begin{tabular}{|c|c|c|c|c|}
\hline \multirow{2}{*}{ Water use } & \multirow{2}{*}{$\begin{array}{l}\text { Ground } \\
\text { water } \\
\text { (Mgal } / \text { d) }\end{array}$} & \multirow{2}{*}{$\begin{array}{l}\text { Surface } \\
\text { water } \\
(\text { Mgal } / \text { d) }\end{array}$} & \multicolumn{2}{|c|}{ Total } \\
\hline & & & $(\mathrm{Mgal} / \mathrm{d})$ & (percent) \\
\hline Public & 8.5 & 0 & 8.5 & 5.6 \\
\hline Domestic & 8.0 & 0 & 8.0 & 5.3 \\
\hline Industrial & .23 & 0 & .23 & .1 \\
\hline Irrigation ${ }^{1}$ & 30 & 105 & $135^{\circ}$ & 88.8 \\
\hline Thermoelectric & 0 & .24 & .24 & .2 \\
\hline Total & 46.73 & 105.24 & 151.97 & \\
\hline
\end{tabular}

${ }^{1}$ Excludes irrigation water obtained from dewatering. 


\section{Use of Water from the Floridan Aquifer System for Public-Water Supply}

Prior to the $1980^{\prime} \mathrm{s}$, most water from the Floridan aquifer system could be used only for irrigation, because its high mineral content generally made the water nonpotable. However, with the advent of the reverse osmosis method of treatment that eliminates objectionable minerals, and with declining treatment cost, water from the Floridan aquifer system can be used as a source for the production of potable water. In places, particularly along the barrier beach, where the surficial aquifer system cannot provide enough freshwater for public supply, reverse osmosis facilities are often used. In June 1985, the county-owned reverse osmosis treatment plant near os lo provided about $1 \mathrm{Mgal} / \mathrm{d}$ of water from two wells that tap the Floridan aquifer system to its service area south and west of Vero Beach. Another reverse osmosis treatment plant (North Beach Water Company) at Wabasso Beach has supplied about $0.06 \mathrm{Mgal} / \mathrm{d}$ of water from two wells in the Floridan aquifer system to the supply system on the Barrier Island between January and May 1985.

\section{Irrigation Water Use}

Approximately 124,000 acres (35 percent) of the total area of Indian River County (351,000 acres) are in agricultural use. About 94,000 acres (76 percent) are irrigated with large quantities of water from wells that tap the Floridan aquifer system. Agricultural land is used chiefly for citrus groves, pasture, and truck farming. Small acreages are used for other types of agriculture (nurseries and tropical-fish farming, for example). Irrigation is greatly reduced or ceases during rainy periods but commonly resumes shortly thereafter. Most irrigation is done during the latter part of the dry season, which extends from November through April or May, but with the approach of the rainy season (June through October), extended dry periods commonly occur and water use for crop irrigation may be considerable.

The changes in land use affecting the pattern of irrigation in the county will probably continue in the future. Along the main north-south road in the county (U.S. Highway 1), and along the main east-west road (State Road 60), urban development is replacing groves, so irrigation water use there is decreasing. In other areas, such as near Fellsmere, large areas of citrus groves are being planted. Irrigation water use in these places will increase accordingly.

On the Barrier Island, north of Vero Beach, land use is changing from citrus groves to mostly residential. Bermes (1958, p. 39) reported that $6.8 \mathrm{Mgal} / \mathrm{d}$ of irrigation water was withdrawn from about 90 wells in this area during 1951. If the current trend continues as predicted by county planners, most of the groves on the Barrier Island will probably be replaced with urban development in the next decade (1985-95), so irrigation water use will be minimal. Additional public-water supply systems using the reverse osmosis treatment will probably be installed. The amount of water used for public-water supplies will probably never exceed the amount that was previously used for irrigation. 
Two types of irrigation systems are generally used in the county--flood and low volume (microjet); some overhead sprinkling is also done. In the flood system, water is applied by ditches or laterals that radiate from large open canals. In low-volume irrigation, water is typically distributed by pipeline and applied as a small jetspray to each tree in the grove. Flood irrigation, which currently uses mostly surface water, is still used by the majority of groves, but the low-volume system, which commonly uses ground water, is steadily increasing in use. The low-volume system is considered more efficient because evaporation is minimized during application. As the use of the low-volume system increases and replaces the floodirrigation system, the use of ground water will increase and the use of surface water will decrease. However, ground-water use could possibly decline or remain about the same if large tracts of groves are converted to urban development. Data are currently (1985) not available on the amounts of water required for low-volume irrigation. In 1984, an estimated 78 percent of the water used for irrigation was surface water $(105 \mathrm{Mgal} / \mathrm{d}$ ) and 22 percent was ground water (30 Mga1/d).

The amount of water withdrawn from the Floridan aquifer system and used for irrigation in the county is difficult to ascertain. An irrigation-use inventory that shows areal and seasonal distribution of discharge from the Floridan does not exist. Pride (1973) reported that total irrigation use (surface water and ground water) in 1970 was $132 \mathrm{Mgal} / \mathrm{d}$. Prior to 1985, many estimates of water use for irrigation in the county were based on permitted use which did not consider seasonal rainfall and surface-water storage. For example, contribution of water from the Floridan aquifer system in 1970 was reported as $100 \mathrm{Mgal} / \mathrm{d}$--up $50 \mathrm{Mgal} / \mathrm{d}$ from 1951 (Crain and others, 1975 p. 28). After considering the factors of seasonal rainfall and surface-water storage, Marella (1986, p. 70) reported total agricultura1irrigation use in 1985 as $135.61 \mathrm{Mgal} / \mathrm{d}$. Ground-water and surface-water uses were reported as $28.43 \mathrm{Mgal} / \mathrm{d}$ and $107.18 \mathrm{Mgal} / \mathrm{d}$, respectively.

\section{SUMMARY AND CONCLUSIONS}

Indian River County has an area of $549 \mathrm{mi}^{2}$. Much of the drainage in the county has been drastically modified since the 1900's and is presently (1985) undergoing further change. Vast sections of the St. Johns Marsh that previously were part of the St. Johns River drainage area in the western half of the county have been diked and channeled for agricultural use. Most drainage is now eastward to the Indian River. In the eastern part of the county, residential and commercial developments are replacing citrus groves. The surficial aquifer system and the Floridan aquifer system are the sources of all ground water used in Indian River County. The two systems contain ground water that ranges in salinity from fresh to brine. High chloride concentration is the chief water-quality problem in the county.

In eastern Indian River County, the surficial aquifer system consists of a 100-to 150-foot-thick "clastic zone" (combined Holocene deposits and Fort Thompson and Anastasia Formations) and an underlying 0 - to 60-foot-thick "shallow rock zone" (Tamiami Formation). The thickness of the surficial aquifer system generally increases in a southerly direction, from about a 100 feet in the northern part of the county to about 200 feet south of State Road 60 . 
The Floridan aquifer system consists of about 2,800 feet of carbonate rocks, subdivided on the basis of permeability, into the Upper Floridan aquifer (about 350-650 feet thick), the middle semiconfining unit (about 20-120 feet thick), and the Lower Floridan aquifer (about 2,000 feet thick). The surficial and Floridan aquifer systems are separated by a low permeability rock unit known as the intermediate confining unit.

Transmissivities of the surficial aquifer system range from 1,500 to $11,000 \mathrm{ft}^{2} / \mathrm{d}$. Transmissivities tend to be lower in the shallow rock zone than in the clastic zone. At Vero Beach, where wells penetrate both zones, transmissivities range from 2,400 to $6,300 \mathrm{ft}^{2} / \mathrm{d}$. Specific capacities range from 21 to 70 (gal/min)/ft in eastern Indian River County, and range from 9 to 36 (gal/min)/ft in the Vero Beach well field. Yields of wells that tap both the clastic and the shallow rock zones in the Vero Beach well field are as much as $1,200 \mathrm{gal} / \mathrm{min}$. The lowest well yields in the county (less than $10 \mathrm{gal} / \mathrm{min}$ ) occur in marsh areas in the central part of the county.

Water levels in the surficial aquifer system in eastern Indian River County may vary substantially from one location to another. Water levels generally fluctuate in response to seasonal changes in climate and pumping from wells but may also fluctuate in response to manipulation of flows in the drainage network in the county. Water levels in the Vero Beach well field during the May 1981 drought, were as low as 39 feet below sea level in wells that tap the surficial aquifer system; levels were lowest east and north of the airstrip. In May 1984, water levels had recovered substantially and were only 11 feet below sea level in some wells. However, water levels remained lowest near the airstrip.

Yields of many wells in the Vero Beach well field decreased in 1981 owing to the large drawdowns in the surficial aquifer system caused by longterm, continuous pumping. The problem was alleviated by implementing a well field management program that involved alternating withdrawals between sets of wells spaced far enough apart so as to minimize interfering drawdowns. In addition, a few wells were deepened to penetrate the shallow rock zone, and several new wells were installed to replace abandoned wells.

Pumpage in the Vero Beach well field approximately doubled during the 10-year period 1975-85 and peaked to about $9.5 \mathrm{Mgal} / \mathrm{d}$ in the spring of 1981 , during a major drought. Coinciding with the increase in pumpage, however, water levels in the surficial aquifer system declined in the vicinity of the Vero Beach well field. Water-level measurements made in the surficial aquifer system near the Vero Beach well field in April 1971 and May 1984 indicate that water levels generally declined about 15 to 19 feet.

The surficial aquifer system in Indian River County is recharged mostly by infiltration of rainfall and by some periodic downward percolation of irrigation water. The aquifer receives little recharge from the underlying Floridan aquifer system because, though heads in the Floridan are generally higher than heads in the surficial aquifer system, a thick section of low permeability strata (the Hawthorn Formation) effectively separates the surficial and Floridan aquifer systems. Discharge from the surficial aquifer system is from seepage to the ocean, lakes, rivers, and canals; evapotranspiration; and withdrawals from wells. 
Chloride concentrations in water from wells in the shallow rock zone in eastern Indian River County are generally below $100 \mathrm{mg} / \mathrm{L}$ except along Sebastian Creek and the Barrier Island where concentrations exceed $250 \mathrm{mg} / \mathrm{L}$, and the east Vero Beach well field area where concentrations range from less than 100 to more than $1,000 \mathrm{mg} / \mathrm{L}$. Water from observation wells east of the Vero Beach well field and approximately 1,000 feet west of the Indian River, have chloride concentrations greater than $20,000 \mathrm{mg} / \mathrm{L}$.

Chloride concentrations in water from wells in the clastic zone also increase in an easterly direction, but concentrations are not as high as those in water from the shallow rock zone wells along the Indian River. Chloride concentrations in the clastic zone are generally less than $250 \mathrm{mg} / \mathrm{L}$ west of the Indian River but exceed $250 \mathrm{mg} / \mathrm{L}$ on the Barrier Island.

The high chloride concentration in some wells that tap the surficial aquifer system may be due to the intrusion of seawater or the intrusion of water from the Floridan aquifer system. Water from the Floridan aquifer system can be introduced into the surficial aquifer system by upward leakage around the casing of wells in the Floridan, corroded-through well casings, or by downward infiltration of irrigation water from the Floridan aquifer system.

Excluding the area east of the Vero Beach well field, the greatest chloride concentrations in water from wells in the surficial aquifer system generally occur south of Main Canal. Concentrations are lowest in the area of the airstrip coincident with the area of maximum drawdown in the Vero Beach well field. Chloride concentrations have increased in a few wells in the well field but changes have been relatively small. Between 1976 and 1983, the average chloride concentration in six production wells increased about $36 \mathrm{mg} / \mathrm{L}$. However, average concentrations in four other wells were unchanged. The increases in chloride concentrations occurred in wells scattered throughout the area and were probably related to the increase in well-field pumpage from $5.44 \mathrm{Mgal} / \mathrm{d}$ in 1976 to $8.00 \mathrm{Mgal} / \mathrm{d}$ in 1983.

Assuming the surficial aquifer system receives 10 inches of natural recharge per year, about $67 \mathrm{Mgal} / \mathrm{d}$ of water is theoretically available for withdrawal in eastern Indian River County. This implies that sufficient water may be available for public-supply use in the foreseeable future in the county if development does not reduce the natural recharge rate and withdrawals are properly managed. In the eastern part of the county, highyielding wells completed in the surficial aquifer system are most likely to be found along the Atlantic Coastal Ridge west of U.S. Highway 1.

Problems relating to saltwater intrusion of the surficial aquifer system can be minimized if all new wells are tested for saltwater during installation and production, and if all unused wells in the Floridan aquifer system are plugged from bottom to top. The occurrence and extent of saltwater intrusion into the surficial aquifer can be assessed only if long-term water-quality-monitoring programs are maintained.

About 65 percent of all ground water used in the county is from the Floridan aquifer system. The system, which is about 2,800 feet thick, in descending order, consists of the Upper Floridan aquifer, the middle semiconfining unit, and the Lower Floridan aquifer. The hydrology of the 
Floridan aquifer system is complex, and considerable variation in yield and water quality may be found in nearby wells of equal depth. The permeability of the Upper Floridan aquifer generally is higher than the Lower Floridan aquifer. The most productive water-yielding zones are in the Avon Park Formation in the Upper Floridan aquifer. The Lower Floridan aquifer may also be productive in places. We1ls more than 700 feet deep in the eastern part of the county are probably completed in the Lower Floridan aquifer. Transmissivities of the Floridan aquifer system as determined from individual aquifer tests range from about $10,000 \mathrm{ft}^{2} / \mathrm{d}$ from a well in the Upper Floridan aquifer to $1.5 \times 10^{6} \mathrm{ft}^{2} / \mathrm{d}$ from an injection we11 completed in the Boulder Zone in the Lower Floridan aquifer. However computer model simulations of the regional ground-water system, indicate that, generally, transmissivities are in the range of 65,000 to $200,000 \mathrm{ft}^{2} / \mathrm{d}$. Specific capacities of 37 wells that tap the Floridan aquifer system range from 1 (gal/min)/ft to 200 (gal/min)/ft), with a median of $67(\mathrm{gal} / \mathrm{min}) / \mathrm{ft}$. specific capacity data indicate lower than average specific capacities in western Indian River County, higher than average values in the central part, and probably low values east of a fault trace along the Indian River.

Most wells completed in the Floridan aquifer system flow. Measured flow rates range from 30 to $2,000 \mathrm{gal} / \mathrm{min}$ with a median of $650 \mathrm{gal} / \mathrm{min}$. A flow of $6,000 \mathrm{gal} / \mathrm{min}$ is reported from a well completed at a depth of 1,350 feet. Wells in the Floridan aquifer system are generally capable of yielding several hundred gallons of water per minute. Inventoried irrigation wells range from 233 feet to 1,272 feet in depth--median depth is 700 feet. Average well depths have increased from about 650 feet in 1950 to about 900 feet in 1985 in response to a demand for higher well yields. Well casings generally extend only into the intermediate confining unit (Hawthorn Formation), which directly overlies the Floridan aquifer system. Many wells are uncased at depths below about 200 feet. Corroded-through steel well casings are a significant problem, and the use of plastic (polyvinylchloride) casing is becoming common. More than 90 percent of inventoried we11s in the Floridan aquifer system are used for irrigation. In those places where yields or water quality from wells in the surficial aquifer system is a problem, water from wells in the Floridan aquifer system has been successfully used for public water supply after reverse osmosis treatment. The public supply system at Vero Beach utilizes water from two wells in the Floridan aquifer system to supplement the yield from a well field that taps the surficial aquifer system.

The regional ground-water movement in the Upper Floridan aquifer is east from the recharge area in eastern Polk and western Highlands County. Natural discharge is mostly upward leakage through the intermediate confining unit. The potentiometric surface of the Upper Floridan aquifer, when most stressed in May, generally ranges from an altitude of about 30 feet along the coastline to about 50 feet on the Talbot terrace in the western part of the county. Potentiometric contours shift slightly eastward toward the Atlantic Ocean between May and September because of the recharge from summer (wet season) rains and curtailment of irrigation pumping. Water levels in September are generally 2 to 5 feet higher than levels in May, but if rainfall is deficient, levels in May can be as much as 15 feet lower than in september in heavily pumped areas. The rainfall deficit of about 19 inches during the 1980-81 drought caused record low water levels in many wells in May 1981. Water levels in wells in the Lower Floridan aquifer 
probably stand several feet higher than wells in the Upper Floridan aquifer, so wells that penetrate both units have resultant combination heads of the producing zones penetrated.

Long-term trends that may indicate declining water levels due to development are difficult to ascertain because variations in natural recharge may mask the trend. Water levels in the Floridan aquifer system in the generally undeveloped western part of the county declined 8 to 10 feet in the period between the $1930^{\prime}$ s and 1978, due to the effects of regional pumping. In the eastern part of the county, levels declined about 16 to 24 feet in the 50-year period 1934 to 1984, but most of the declines occurred prior to 1976 .

In the future, water levels in the Floridan aquifer system may decline locally in those areas of the county where pumpage is increasing, such as in the Fellsmere area and in the area of the reverse osmosis treatment plant near 0slo. Curtailed water use in other parts of the county may allow water levels to rise, in areas such as the Indian River Water Control District where irrigation use is declining due to urban development.

Water from the Floridan aquifer system is relatively highly mineralized and the predominant constituents are sodium and chloride. Salinity increases with depth and is a function of flushing out of the ancient seawater trapped in the sediments during an earlier geologic time. Water from the Floridan aquifer system commonly exceeds the Florida Department of Environmental Regulation maximum contaminant levels for public drinking water systems of $250 \mathrm{mg} / \mathrm{L}$ for chloride and $500 \mathrm{mg} / \mathrm{L}$ for dissolved-solids concentration.

In places, corroded-through casings of wells in the Floridan aquifer system have allowed high chloride concentration water to intrude the surficial aquifer system. High heads, generally 10 to 30 feet above land surface, at present (1985) prevent saltwater contamination of the Floridan aquifer system from the Indian River or the Atlantic Ocean. The high heads also prevent surface pollution from moving downward into the aquifer. However, pollutants could be introduced into the Floridan aquifer system from recharge areas mostly outside the county, and heavy pumping can cause upconing of highly saline water. Periodic sampling of monitor wells would be needed to recognize incipient quality-of-water changes that could cause problems.

Chloride concentrations may vary considerably both areally and vertically. Chloride concentrations in water from wells in the Floridan aquifer system that flow continuously have less yearly variation than concentrations from wells that are periodically allowed to flow. Water in the Upper Floridan aquifer is fresher and less variable in quality than water in the Lower Floridan aquifer. Concentrations generally increase slightly with depth in the Upper Floridan aquifer but may increase rapidly with depth in the Lower Floridan. Chloride concentrations in water from the Upper Floridan aquifer range from 20 to $1,400 \mathrm{mg} / \mathrm{L}$. Concentrations less than $250 \mathrm{mg} / \mathrm{L}$ occur primarily in the western, southwestern, and central part of the county. 
Chloride concentrations in water from wells that yield mostly from the Lower Floridan aquifer range from 250 to $2,920 \mathrm{mg} / \mathrm{L}$. In the eastern half of the county, concentrations generally exceed $500 \mathrm{mg} / \mathrm{L}$. Water with chloride concentrations of $400 \mathrm{mg} / \mathrm{L}$ or less occurs in a narrow band along the trace of the Atlantic Coastal Ridge in the northern half of the county. Anomalously high chloride concentrations in water from some wells probably are a site-specific condition caused by heavy pumping from a relatively deep well.

Average chloride concentrations of water in the Floridan aquifer system throughout the county have increased only about 6 percent in the 15-year period 1968-83. However, chloride concentrations in water from 26 wells sampled during a 1951-52 study increased an average of about 20 percent between the early 1950's and 1985. Chloride concentrations in the Vero Beach area are apparently increasing; concentrations in water from we $1193 \mathrm{~F}$ increased from $300 \mathrm{mg} / \mathrm{L}$ in 1975 to $476 \mathrm{mg} / \mathrm{L}$ in 1985 , and concentrations in well $94 \mathrm{~F}$ increased from $285 \mathrm{mg} / \mathrm{L}$ in 1976 to $384 \mathrm{mg} / \mathrm{L}$ in 1985 . At the old Vero Beach Power Plant, chloride concentrations in water from well $73 \mathrm{~F}$ increased from $291 \mathrm{mg} / \mathrm{L}$ in 1921 to $790 \mathrm{mg} / \mathrm{L}$ in 1983.

Large quantities of moderately mineralized irrigation water from wells in the Floridan aquifer system commonly mix with less mineralized surface water and water from the surficial aquifer system in the canals that are used to drain or irrigate cropland.

The specific conductance of water in a typical canal, South Canal, during the water year 1984 ranged between 900 to $1,700 \mu \mathrm{S} / \mathrm{cm}$ (about 250-450 $\mathrm{mg} / \mathrm{L}$ chloride, respectively). The highest conductance of $2,880 \mu \mathrm{S} / \mathrm{cm}$ (about $850 \mathrm{mg} / \mathrm{L}$ chloride) was in May 1984 when only 1.02 inches of rain fell, and the lowest conductance of $540 \mu \mathrm{S} / \mathrm{cm}$ (about $150 \mathrm{mg} / \mathrm{L}$ chloride) was in October 1983 which had a record high rainfall of 15.58 inches.

About $8.5 \mathrm{Mgal} / \mathrm{d}$ of ground water is used for public supply in the county, mostly by Vero Beach. In June 1985, the county-owned reverse osmosis treatment plant near Oslo provided about $1 \mathrm{Mgal} / \mathrm{d}$ of public-supply water to its service area south and west of Vero Beach from two wells that tap the Floridan aquifer system. Another reverse osmosis plant at Wabasso Beach (North Beach Water Company) supplied about $0.06 \mathrm{Mgal} / \mathrm{d}$ of water from two wells in the Floridan aquifer system to services on the Barrier Island between January and May 1985. The largest use of ground water in the county is for irrigation. An additional $8 \mathrm{Mgal} / \mathrm{d}$ of ground water is used for domestic supply. Industrial and thermoelectric use of ground water is minimal. In 1984, an estimated 22 percent of the water used for irrigation in the county was ground water ( $30 \mathrm{Mgal} / \mathrm{d}$ ).

About 35 percent of the total area of Indian River County is in agricultural use, of which about 75 percent is irrigated with large quantities of water from wells that tap the Floridan aquifer system. Most agricultural land use is citrus groves--some is in pasture and truck farming. Changes in land use are affecting the pattern of irrigation. Urban development is replacing groves along sections of U.S. Highway 1 and State Road 60, so there irrigation water use is decreasing. In other areas, such as near Fellsmere, large areas of citrus groves are being developed--irrigationwater use will probably increase, accordingly. On the Barrier Island, 
land use is changing from citrus groves to residential. Most of the groves on the Barrier Island may be replaced by urban development by 1995 . At that time, water use there will probably be mostly for public supply and the amount of water used for that purpose is not likely to equal or exceed the amount that has been used for irrigation in the past.

\section{SELECTED REFERENCES}

Barraclough, J.T., 1962, Ground-water resources of Seminole County, Florida: Florida Geological Survey Report of Investigations 27, $91 \mathrm{p}$.

Bermes, B.J., 1958, Interim report on geology and ground-water resources of Indian River County, Florida: Florida Geological Survey Information Circular 18, $74 \mathrm{p}$.

Brown, M.P., and Reece, D.E., 1979, Hydrogeologic reconnaissance of the Floridan aquifer system Upper East Coast Planning Area: West Palm Beach, South Florida Water Management District Technical Map Series 79-1, plates 1-10B.

Brown, R.H., 1963, Drawdowns resulting from cyclic intervals of discharge, in Bentall, Ray, compiler, Methods of determining permeability, transmissibility, and drawdown: U.S. Geological Survey Water Supply Paper $1536-\mathrm{I}, \mathrm{p} .324-330$.

Burns, W.S., 1983, We11 plugging applications to the inter-aquifer migration of saline groundwater in Lee County, Florida: West Palm Beach, South Florida Water Management District Technical Publication 83-8, 77 p., appendix I-III.

Campbe11, Dean, Munch, D.A., Johnson, Richard, Parker, M.P., Parker, Bruce, Rao, D.V., Marella, Richard, and Albanesi, Edward, 1984, Section III Water administration and regional management, Chapter 13, St. Johns River Water Management District, in Fernald, E.A., and Patton, D.J., eds., Water Resources Atlas of Florida, Tallahassee, Florida State University, p. 158-177.

CH2M Hill, 1979, Injection test well and multizone monitor well Indian River Plant: Hydrogeologic Report, project no. GN 54801.80; consultant's report prepared for Hercules Inc., in files of U.S. Geological Survey, Orlando, Fla., 6 chapters, appendix A-K.

Cooke, C.W., 1939, Scenery of Florida: Florida Geological Survey Bulletin $17,118 \mathrm{p}$.

.... 1945, Geology of Florida: Florida Geological Survey Bulletin 29, $339 \mathrm{p}$.

Crain, L.J., Hughes, G.H., and Sne11, L.J., 1975, Water resources of Indian River County, Florida: Florida Bureau of Geology Report of Investigations $80,75 \mathrm{p}$.

Florida Department of Environmental Regulation, 1982, Public drinking water systems: Chapter 17-22 in Florida Administrative Code.

Florida Department of Natural Resources, 1970, Florida water and related land resources-St. Johns River basin: Tallahassee, Fla., 205 p.

Florida Department of State, 1978, Rules of the Department of Environmenta1 Regulation, Water-Quality Standards, Chapter 17-3, in Florida Administrative Code: Tallahassee, Fla.

Frazee, J.M., and Johnson, R.A., 1983, The hydrology of the post Hawthorn shallow rock zone of Brevard and Indian River Counties: Paper presented at the Southeastern Section of the Geological Society of America, Tallahassee, Fla. 


\section{SELECTED REFERENCES - - Continued}

Gee and Jenson, 1980, Future water supply development for the City of Vero Beach, Florida: Consultant's report prepared for City of Vero Beach, in files of St. Johns River Water Management District, Palatka, Fla., $167 \mathrm{p}$.

Geraghty and Miller, Inc., 1978, Availability of ground water at Hobart Park, Indian River County, Florida: Consultant's report prepared for Indian River County Commissioners, in files of St. Johns River Water Management District, Palatka, Fla., 40 p.

-... 1981a, Drilling and testing for public water supply from the shallow aquifer, Sebastian Highlands, Indian River County, Florida: Consultant's report prepared for General Development Corp., Miami, Fla., in files of St. Johns River Water Management District, Palatka, Fla., 45 p. .... 1981b, Installation and testing of production and monitoring we1ls, South Taxing District, Indian River County, Florida: Consultant's report prepared for Indian River County Commissioners, in files of St. Johns River Water Management District, Palatka, Fla., 138 p.

Johnston, R.H., Krause, R.E., Meyer, R.W., Ryder, P.D., Tibbals, C.H., and Hunn, J.D., 1980, Estimated potentiometric surface for the Tertiary limestone aquifer system, southeastern United States, prior to development: U.S. Geological Survey Open-File Report 80-406, scale $1: 1,000,000,1$ sheet.

Kohout, F.A., 1965, A hypothesis concerning cyclic flow of salt water related to geothermal heating in the Floridan aquifer: Transactions of the New York Academy of Sciences, ser. II, 28, no. 2, p. 249-271.

Krieger, R.A., Hatchett, J.L., and Poole, J.L., 1957, Preliminary survey of the saline-water resources of the United States: U.S. Geological Survey Water-Supply Paper 1374, 172 p.

Lloyd, J.M., 1985, Annotated bibliography of Florida basement geology and related regional and tectonic studies including an appendix of Florida deep wel1 data: Florida Bureau of Geology Information Circular 98, $72 \mathrm{p}$.

MacNeil, F.S., 1949, Pleistocene shorelines in Florida and Georgia: U.S. Geological Survey Professional Paper 221-F, p. 91-107.

Marella, Richard, 1986, Annual water use survey: 1985: Palatka, Fla., St. Johns River Water Management District Technical Publication SJ86-5, $117 \mathrm{p}$.

McKee, J.E., and Wolf, H.W., 1963, water quality criteria (2d ed.): California State Water Quality Control Board Publication 3-A, 548 p.

Miller, J.A., 1982, Thickness of the upper permeable zone of the Tertiary limestone aquifer system, southeastern United States: U.S. Geological Survey Water-Resources Investigations Open-File Report 81-1179, scale $1: 1,000,000,1$ sheet.

.... 1986, Hydrogeologic framework of the Floridan aquifer system in Florida and parts of Georgia, Alabama, and South Carolina: U.S. Geological Survey Professional Paper 1403-B, 91 p.

National Oceanographic and Atmospheric Administration, Climatological data, Florida, annual summaries.

Parker, G.G., Ferguson, G.E., Love, S.K., and others, 1955, Water resources of southeastern Florida: U.S. Geological Survey Water-Supply Paper $1255,965 \mathrm{p}$.

Phelps, G.G., 1984, Recharge and discharge areas of the Floridan aquifer in the St. Johns River Water Management District and vicinity, Florida: U.S. Geological Survey Water-Resources Investigations 82-4058, 1 sheet. 
Planert, Michael, and Aucott, W.R., 1985, Water-supply potential of the Floridan aquifer in Osceola, eastern Orange, and southwestern Brevard Counties, Florida: U.S. Geological Survey Water-Resources Investigations Report 84-4135, 69 p.

Pride, R.W., 1973, Estimated use of water in Florida, 1970: Florida Bureau of Geology Information Circular 83, $31 \mathrm{p}$.

Seaburn and Robertson, Inc., 1983a, The North Beach Water Company reverse osmosis supply well no. 2 construction and aquifer testing report: Consultant's report prepared for the North Beach Water Co., Vero Beach, Fla., in files of St. Johns River Water Management District, Palatka, Fla., 34 p.

...- 1983b, Marsh Island reverse osmosis supply well completion report: Consultant's report prepared for Florida Communities of Vero Beach, in files of U.S. Geological Survey, Orlando, Fla., 31 p.

Sprinkle, C.L., 1982, Chloride concentration in water from the upper permeable zone of the Tertiary limestone aquifer system, southeastern United States: U.S. Geological Survey Water-Resources Investigations Open-File Report 81-1103, scale 1:1,000,000, 1 sheet.

Stringfield, V.T., 1936, Artesian water in the Florida peninsula: U.S. Geological Survey Water-Supply Paper 773-C, p. 115-195.

-... 1966, Artesian water in Tertiary limestone in the southeastern states: U.S. Geological Survey Professional Paper 517, 226 p.

Tibbals, C.H., 1978, Effects of paved surfaces on recharge to the Floridan aquifer in east-central Florida--a conceptual model: U.S. Geological Survey Water-Resources Investigations 78-76, $42 \mathrm{p}$.

...- 1981, Computer simulation of the steady-state flow system of the Tertiary limestone (Floridan) aquifer system in east-central Florida: U.S. Geological Survey Water-Resources Investigations Open-File Report $81-681,31 \mathrm{p}$.

...- in press, Hydrology of the Floridan aquifer system in east-central Florida: U.S. Geological Survey Professional Paper 1403-E.

U.S. Environmental Protection Agency, 1976, Quality criteria for water: U.S. Environmental Protection Agency report EPA-44019-76-023, 501 p.

University of Florida, 1986, Florida estimates of population, April 1, 1985 , states, counties and municipalities: Gainesville, University of Florida Bureau of Economic and Business Research, Population Program, $48 \mathrm{p}$.

White, W.A., 1970, The geomorphology of the Florida peninsula: Florida Bureau of Geology Bulletin 51, 164 p. 
SUPPLEMENTARY DATA I

We1ls in the surficial aquifer system used for data analysis

[Altitude refers to distance above sea level]

\begin{tabular}{|c|c|c|c|c|c|c|c|}
\hline \multirow{2}{*}{$\begin{array}{l}\text { We11 } \\
\text { No. }\end{array}$} & \multirow{2}{*}{$\begin{array}{l}\text { Lati- } \\
\text { tude }\end{array}$} & \multirow{2}{*}{$\begin{array}{l}\text { Longi- } \\
\text { tude }\end{array}$} & \multirow[b]{2}{*}{ We11 name } & \multirow{2}{*}{$\begin{array}{l}\text { Altitude } \\
\text { of land } \\
\text { surface } \\
\text { (feet) }\end{array}$} & \multirow{2}{*}{$\begin{array}{l}\text { Well } \\
\text { depth } \\
\text { (feet) }\end{array}$} & \multicolumn{2}{|c|}{ Casing } \\
\hline & & & & & & $\begin{array}{l}\text { Depth } \\
\text { (feet) }\end{array}$ & $\begin{array}{l}\text { Diameter } \\
\text { (inches) }\end{array}$ \\
\hline 1S & 273348 & 0801930 & SJRWMD & 9.88 & 147 & 108 & 4 \\
\hline $2 S$ & 273356 & 0802232 & Vero Beach Highlands & 42 & 127 & -- & -- \\
\hline $3 S$ & 273356 & 0802237 & Vero Beach Highlands & 37 & 127 & -- & - \\
\hline $4 S$ & 273418 & 0802909 & I.R. Correctional Inst. & 25 & 65 & -- & -- \\
\hline $5 S$ & 273448 & 0802658 & USGS & 20 & 62 & -- & -- \\
\hline $6 S$ & 273457 & 0802336 & Randy Saxton & -- & - & -- & 2 \\
\hline $7 S$ & 273459 & 0802254 & Morgan Thomas & -- & 70 & -- & 2 \\
\hline $8 S$ & 273459 & 0802307 & Shirley McDougald & -- & -- & - & 1.25 \\
\hline 9S & 273505 & 0802458 & Holiday Village & -- & 65 & -- & 4 \\
\hline $10 \mathrm{~S}$ & 273508 & 0802419 & James Whalen & -- & -- & - & 2 \\
\hline $11 S$ & 273508 & 0802523 & John Metherall & - & 80 & - & 2 \\
\hline $12 \mathrm{~S}$ & 273509 & 0802257 & Father \& Son Appl. & - & 65 & - & 2 \\
\hline $13 \mathrm{~S}$ & 273509 & 0802258 & Father \& Son Appl. & 37 & 45 & - & -- \\
\hline $14 S$ & 273511 & 0802448 & John Streeter & -- & -- & -- & -- \\
\hline $15 S$ & 273512 & 0802625 & Barbara Nolte & - & 73 & -- & 2 \\
\hline $16 S$ & 273513 & 0802223 & Entomological Inst. & -- & -- & -- & 2 \\
\hline $17 \mathrm{~S}$ & 273513 & 0802240 & Undetermined & 10 & 90 & - & -- \\
\hline $18 \mathrm{~S}$ & 273513 & 0802851 & Ocean Spray Industries & 26 & 63 & -- & -- \\
\hline 19S & 273514 & 0802240 & Undetermined & 10 & 90 & -- & -- \\
\hline $20 \mathrm{~s}$ & 273515 & 0802505 & Oaks Paradise MHP & 21 & 87 & -- & - \\
\hline $21 \mathrm{~s}$ & 273518 & 0801959 & Smith & 13 & 14 & 11 & 2 \\
\hline $22 S$ & 273518 & 0802731 & Hyatt Fruit Co. & 21 & 65 & -- & - - \\
\hline $23 S$ & 273518 & 0802731 & USGS & 21 & 120 & -- & -- \\
\hline $24 S$ & 273523 & 0802346 & Ear1 McGiff & -- & 98 & -- & 2 \\
\hline $25 S$ & 273539 & 0802246 & Vista Royale & 11 & 100 & - & -- \\
\hline $26 S$ & 273543 & 0802247 & Vista Royale & 9 & 100 & - & -- \\
\hline $27 \mathrm{~S}$ & 273556 & 0802250 & Vista Royale & 11 & 91 & - & -- \\
\hline $28 \mathrm{~S}$ & 273558 & 0802303 & Knights of Columbus & -- & -- & -- & 2 \\
\hline $29 S$ & 273603 & 0802250 & Vista Royale & 9 & 91 & - & - \\
\hline $30 \mathrm{~S}$ & 273604 & 0802449 & Undetermined & 23 & 100 & - & -- \\
\hline $31 \mathrm{~s}$ & 273607 & 0802328 & SJRWMD & 22.37 & 143 & 101 & 4 \\
\hline $32 \mathrm{~S}$ & 273607 & 0802328 & SJRWMD & -- & 53 & 43 & 2 \\
\hline $33 \mathrm{~S}$ & 273608 & 0802252 & Vista Royale & 11 & 92 & - & -- \\
\hline $34 \mathrm{~S}$ & 273629 & 0802328 & F.H. Buffington & 24 & 86 & -- & - \\
\hline $35 \mathrm{~S}$ & 273713 & 0802422 & H.E. Chappel & 22 & 80 & - & - - \\
\hline
\end{tabular}


We11s in the surficial aquifer system used for data analysis--Continued

\begin{tabular}{|c|c|c|c|c|c|c|c|}
\hline \multirow{2}{*}{$\begin{array}{l}\text { Well } \\
\text { No. }\end{array}$} & \multirow{2}{*}{$\begin{array}{l}\text { Lati- } \\
\text { tude }\end{array}$} & \multirow{2}{*}{$\begin{array}{l}\text { Longi- } \\
\text { tude }\end{array}$} & \multirow[b]{2}{*}{ Well name } & \multirow{2}{*}{$\begin{array}{l}\text { Altitude } \\
\text { of land } \\
\text { surface } \\
\text { (feet) }\end{array}$} & \multirow{2}{*}{$\begin{array}{l}\text { Well } \\
\text { depth } \\
\text { (feet) }\end{array}$} & \multicolumn{2}{|c|}{ Casing } \\
\hline & & & & & & $\begin{array}{l}\text { Depth } \\
\text { (feet) }\end{array}$ & $\begin{array}{l}\text { Diameter } \\
\text { (inches) }\end{array}$ \\
\hline $36 \mathrm{~S}$ & 273713 & 0802422 & H.E. Chappe11 & 22 & 33 & - - & $\ldots$ \\
\hline $37 \mathrm{~S}$ & 273731 & 0802122 & S. Valentino & 4 & 20 & - & - \\
\hline $38 \mathrm{~S}$ & 273732 & 0802410 & SJRWMD & 19.37 & 55 & 45 & 2 \\
\hline $39 \mathrm{~S}$ & 273732 & 0802410 & SJRWMD & 21.27 & 123 & 108 & 4 \\
\hline $40 \mathrm{~S}$ & 273734 & 0802329 & Mid-Fla Utilities & 13 & 93 & -- & -- \\
\hline $41 \mathrm{~s}$ & 273736 & 0802327 & Mid-Fla Utilities & 12 & 100 & - & - \\
\hline $42 \mathrm{~S}$ & 273737 & 0802330 & Mid-Fla Utilities & 13 & 93 & - & -- \\
\hline $43 \mathrm{~S}$ & 273737 & 0802342 & City of Vero Beach & - & 130 & 50 & 2 \\
\hline $44 S$ & 273739 & 0802525 & City of Vero Beach & - & 131 & 50 & 2 \\
\hline $45 \mathrm{~S}$ & 273741 & 0802320 & Vero Palms Motel & 11 & 67 & -- & - \\
\hline $46 S$ & 273741 & 0802412 & City of Vero Beach & 17.80 & 120 & 55 & 12 \\
\hline $47 \mathrm{~S}$ & 273743 & 0802131 & C. Smith & 3 & 8 & - & - \\
\hline $48 \mathrm{~S}$ & 273745 & 0802346 & City of Vero Beach & 14.40 & 117 & 55 & 12 \\
\hline $49 \mathrm{~S}$ & 273756 & 0802248 & City of Vero Beach & 4.90 & 100 & 10 & 2 \\
\hline $50 \mathrm{~S}$ & 273756 & 0802301 & Bertha Boettcher & $\ldots$ & 50 & $\cdots$ & - \\
\hline $51 S$ & 273756 & 0802314 & City of Vero Beach & 6.70 & 125 & 10 & 2 \\
\hline $52 \mathrm{~S}$ & 273756 & 0802413 & City of Vero Beach & 20.30 & 140 & 55 & 12 \\
\hline $53 \mathrm{~S}$ & 273757 & 0802345 & City of Vero Beach & 13.70 & 140 & 10 & 2 \\
\hline $54 S$ & 273759 & 0802301 & Marcell St. Thomas & - & 65 & - & 1.5 \\
\hline $55 \mathrm{~S}$ & 273759 & 0802827 & L. Laney & - & -- & - & 1.5 \\
\hline $56 \mathrm{~S}$ & 273801 & 0802301 & Melvin J. Scheidt & - & 33 & 30 & 1.25 \\
\hline $57 \mathrm{~S}$ & 273807 & 0802533 & John D. Grice & $\cdots$ & 45 & 40 & 2 \\
\hline $58 \mathrm{~S}$ & 273808 & 0802305 & City of Vero Beach & 5.10 & 100 & 10 & 2 \\
\hline $59 S$ & 273808 & 0802420 & Bernice Meyer & -- & 60 & - & 1.25 \\
\hline $60 \mathrm{~S}$ & 273809 & 0802303 & Anthony Mirabito & $\cdots$ & 40 & - & 2 \\
\hline $61 S$ & 273811 & 0802306 & B. Pfleiderer & - & 42 & -- & 1.25 \\
\hline $62 \mathrm{~S}$ & 273811 & 0802524 & C.J. Neilsen & - & 60 & -. & 2 \\
\hline $63 S$ & 273811 & 0802824 & C. Schmaltz & - & 25 & - - & 1.5 \\
\hline $64 S$ & 273812 & 0802727 & Fran Price & $\cdots$ & 20 & - & 1.25 \\
\hline $65 S$ & 273812 & 0802901 & Dave Gagliardi & - & 85 & -- & 1.5 \\
\hline $66 S$ & 273813 & 0802454 & D.K. Richardson & - & 60 & - - & 2 \\
\hline $67 \mathrm{~S}$ & 273814 & 0802314 & Earl Mathiak & - & 44 & 40 & 2 \\
\hline $68 \mathrm{~S}$ & 273814 & 0802415 & A.R. Jones & - & 90 & -- & 3 \\
\hline $69 \mathrm{~S}$ & 273814 & 0802526 & Elmer Grant & $\cdots$ & 68 & 63 & 2 \\
\hline $70 \mathrm{~s}$ & 273814 & 0802745 & Bertram Bach & -. & 29 & - & 2 \\
\hline
\end{tabular}


We1ls in the surficial aquifer system used for data analysis--Continued

\begin{tabular}{|c|c|c|c|c|c|c|c|}
\hline \multirow{2}{*}{$\begin{array}{l}\text { Well } \\
\text { No. }\end{array}$} & \multirow{2}{*}{$\begin{array}{l}\text { Lati - } \\
\text { tude }\end{array}$} & \multirow{2}{*}{$\begin{array}{l}\text { Longi - } \\
\text { tude }\end{array}$} & \multirow[b]{2}{*}{ Well name } & \multirow{2}{*}{$\begin{array}{l}\text { Altitude } \\
\text { of land } \\
\text { surface } \\
\text { (feet) }\end{array}$} & \multirow{2}{*}{$\begin{array}{l}\text { Well } \\
\text { depth } \\
\text { (feet) }\end{array}$} & \multicolumn{2}{|c|}{ Casing } \\
\hline & & & & & & $\begin{array}{l}\text { Depth } \\
\text { (feet) }\end{array}$ & $\begin{array}{l}\text { Diameter } \\
\text { (inches) }\end{array}$ \\
\hline $71 S$ & 273814 & 0802824 & Major Surles & -- & 45 & -- & 1.5 \\
\hline $72 S$ & 273814 & 0802828 & C.H. Murtaugh & -- & 47 & -- & $\ldots$ \\
\hline $73 \mathrm{~S}$ & 273815 & 0802418 & Edith MacLean & -. & 70 & - & 2 \\
\hline $74 \mathrm{~S}$ & 273817 & 0802828 & Wm. L. Shelton & - & 47 & - - & 1.5 \\
\hline $75 S$ & 273818 & 0802434 & John Detrick & -- & 60 & -- & 3 \\
\hline $76 S$ & 273818 & 0802503 & John Stone & - - & 50 & - & 2 \\
\hline $77 \mathrm{~S}$ & 273818 & 0802724 & E.A. Hobbs & -- & 600 & - & 3 \\
\hline $78 \mathrm{~S}$ & 273818 & 0802826 & L. Layman & -- & 40 & -- & 1.5 \\
\hline $79 \mathrm{~S}$ & 273819 & 0802429 & Jerry VanKeulen & -. & 87 & -. & 2 \\
\hline $80 S$ & 273819 & 0802545 & City of Vero Beach & 24 & 130 & 65 & 2 \\
\hline $81 S$ & 273821 & 0802413 & 1st United Methodist & - & 60 & - & 3 \\
\hline $82 S$ & 273821 & 0802628 & Haller LaRue & - & 15 & - & 1.25 \\
\hline $83 S$ & 273821 & 0802708 & Charles Reschakh & - & 60 & - & 1.25 \\
\hline $84 S$ & 273822 & 0802420 & City of Vero Beach & 19.30 & 130 & 40 & 2 \\
\hline $85 \mathrm{~S}$ & 273822 & 0802503 & Mrs. David Evans & -- & 60 & - & -- \\
\hline $86 \mathrm{~S}$ & 273822 & 0802623 & A.J. Brackins & -- & 60 & - & 2 \\
\hline $87 \mathrm{~S}$ & 273822 & 0802632 & Philip Junkins & -- & 60 & - & - \\
\hline $88 \mathrm{~S}$ & 273823 & 0802618 & C. Stecher & $\cdots$ & 80 & $\cdots$ & 2 \\
\hline $89 \mathrm{~S}$ & 273823 & 0802631 & Kathy Beatty & - & 60 & - & 1.25 \\
\hline $90 \mathrm{~S}$ & 273823 & 0803115 & USGS & 25 & 120 & - & -- \\
\hline $91 \mathrm{~S}$ & 273824 & 0802729 & M.J. Long & -- & 60 & -- & 1.25 \\
\hline $92 \mathrm{~S}$ & 273829 & 0802355 & City of Vero Beach & 14.60 & 141 & 50 & 2 \\
\hline $93 \mathrm{~S}$ & 273833 & 0802437 & City of Vero Beach & 20 & 135 & 65 & 20 \\
\hline $94 S$ & 273833 & 0802437 & USGS & - & 90 & $\cdots$ & -- \\
\hline $95 \mathrm{~S}$ & 273833 & 0802437 & City of Vero Beach & 21.90 & 135 & 65 & 2 \\
\hline $96 S$ & 273833 & 0802437 & City of Vero Beach & 22.90 & 135 & 65 & 2 \\
\hline $97 \mathrm{~S}$ & 273833 & 0802437 & City of Vero Beach & 21.90 & 135 & 65 & 2 \\
\hline $98 \mathrm{~S}$ & 273833 & 0802437 & City of Vero Beach & 22.30 & 102 & 77 & 2 \\
\hline $99 S$ & 273833 & 0802437 & City of Vero Beach & 23.00 & 53 & 5 & 2 \\
\hline $100 \mathrm{~S}$ & 273838 & 0802450 & City of Vero Beach & 30.60 & 103 & -- & -- \\
\hline $101 S$ & 273842 & 0802447 & USGS & 21 & 55 & -- & -- \\
\hline $102 \mathrm{~S}$ & 273844 & 0802426 & City of Vero Beach & 20 & 105 & 65 & 20 \\
\hline $103 S$ & 273844 & 0802426 & City of Vero Beach & 19.20 & 105 & 65 & 2 \\
\hline $104 \mathrm{~S}$ & 273844 & 0802426 & City of Vero Beach & 19.40 & 105 & 65 & 2 \\
\hline $105 \mathrm{~S}$ & 273844 & 0802426 & City of Vero Beach & 20.20 & 105 & 65 & 2 \\
\hline
\end{tabular}


Wells in the surficial aquifer system used for data analysis--Continued

\begin{tabular}{|c|c|c|c|c|c|c|c|c|c|}
\hline \multirow{2}{*}{$\begin{array}{l}\text { We11 } \\
\text { No. }\end{array}$} & \multirow{2}{*}{$\begin{array}{l}\text { Lati- } \\
\text { tude }\end{array}$} & \multirow{2}{*}{$\begin{array}{l}\text { Longi- } \\
\text { tude }\end{array}$} & \multirow{2}{*}{\multicolumn{3}{|c|}{ We11 name }} & \multirow{2}{*}{$\begin{array}{l}\text { Altitude } \\
\text { of land } \\
\text { surface } \\
\text { (feet) }\end{array}$} & \multirow{2}{*}{$\begin{array}{l}\text { Well } \\
\text { depth } \\
\text { (feet) }\end{array}$} & \multicolumn{2}{|c|}{ Casing } \\
\hline & & & & & & & & $\begin{array}{l}\text { Depth } \\
\text { (feet) }\end{array}$ & $\begin{array}{l}\text { Diameter } \\
\text { (inches) }\end{array}$ \\
\hline $106 \mathrm{~S}$ & 273844 & 0802426 & City & of Vero & Beach & 20 & 90 & 77 & 4 \\
\hline $107 \mathrm{~S}$ & 273844 & 0802426 & City & of Vero & Beach & 20.20 & 50 & 5 & 2 \\
\hline $108 \mathrm{~S}$ & 273844 & 0802520 & City & of Vero & Beach & 22 & 93 & 53 & 10 \\
\hline $109 \mathrm{~S}$ & 273844 & 0802544 & City & of Vero & Beach & 21 & 90 & 52 & 10 \\
\hline $110 \mathrm{~S}$ & 273844 & 0802544 & City & of Vero & Beach & 21 & 127 & 60 & 12 \\
\hline $111 \mathrm{~s}$ & 273846 & 0802609 & City & of Vero & Beach & - & 130 & 75 & 2 \\
\hline $112 \mathrm{~S}$ & 273847 & 0802438 & City & of Vero & Beach & 22 & 80 & - - & - - \\
\hline $113 \mathrm{~S}$ & 273853 & 0802410 & USGS & & & 15 & 48 & - & - - \\
\hline $114 S$ & 273856 & 0802527 & City & of Vero & Beach & 25.30 & 130 & 55 & 12 \\
\hline $115 \mathrm{~S}$ & 273858 & 0802330 & USGS & & & 6 & 54 & -- & -- \\
\hline $116 \mathrm{~S}$ & 273900 & 0802547 & City & of Vero & Beach & 22 & 130 & 60 & 12 \\
\hline $117 \mathrm{~S}$ & 273903 & 0802548 & USGS & & & 22 & 61 & - & -- \\
\hline $118 \mathrm{~S}$ & 273905 & 0802409 & City & of Vero & Beach & 21 & 112 & 60 & 12 \\
\hline $119 \mathrm{~S}$ & 273907 & 0802305 & City & of Vero & Beach & 5 & 92 & -- & 2 \\
\hline $120 \mathrm{~S}$ & 273907 & 0802305 & USGS & & & 4 & 120 & -- & -- \\
\hline $121 \mathrm{~S}$ & 273907 & 0802419 & City & of Vero & Beach & 20.75 & 112 & 60 & 12 \\
\hline $122 \mathrm{~S}$ & 273907 & 0802422 & USGS & & & 20 & 58 & - - & - - \\
\hline $123 S$ & 273907 & 0802422 & USGS & & & 20 & 120 & - - & - - \\
\hline $124 \mathrm{~S}$ & 273907 & 0802440 & City & of Vero & Beach & 21 & 130 & 60 & 12 \\
\hline $125 \mathrm{~S}$ & 273908 & 0802352 & City & of Vero & Beach & 9.10 & 116 & 18 & 2 \\
\hline $126 S$ & 273910 & 0802335 & City & of Vero & Beach & 7.30 & 120 & 10 & 2 \\
\hline $127 \mathrm{~S}$ & 273910 & 0802442 & City & of Vero & Beach & 21 & 130 & 63 & 12 \\
\hline $128 \mathrm{~S}$ & 273913 & 0802420 & City & of Vero & Beach & 17 & 81 & 49 & 10 \\
\hline $129 \mathrm{~S}$ & 273919 & 0802549 & City & of Vero & Beach & 23.90 & 125 & 55 & 12 \\
\hline $130 \mathrm{~S}$ & 273920 & 0802549 & USGS & & & 20 & 120 & -- & - \\
\hline $131 \mathrm{~s}$ & 273921 & 0802416 & City & of Vero & Beach & 15 & 84 & 50 & 10 \\
\hline $132 \mathrm{~S}$ & 273921 & 0802632 & City & of Vero & Beach & 26 & 81 & - & 2 \\
\hline $133 \mathrm{~S}$ & 273923 & 0802612 & City & of Vero & Beach & 22.70 & 140 & 60 & 12 \\
\hline $134 \mathrm{~S}$ & 273923 & 0804718 & USGS & & & 32.21 & 19 & 13 & 6 \\
\hline $135 \mathrm{~S}$ & 273925 & 0802609 & City & of Vero & Beach & 23 & -- & -- & -- \\
\hline $136 \mathrm{~S}$ & 273929 & 0802630 & City & of Vero & Beach & 21.40 & 130 & 50 & 12 \\
\hline $137 \mathrm{~S}$ & 273930 & 0802553 & City & of Vero & Beach & 23.40 & 96 & -- & - \\
\hline $138 \mathrm{~S}$ & 273932 & 0802419 & City & of Vero & Beach & 20 & 112 & 60 & 12 \\
\hline $139 \mathrm{~S}$ & 273935 & 0802321 & City & of Vero & Beach & 2.40 & 135 & 10 & 2 \\
\hline $140 \mathrm{~S}$ & 273935 & 0802336 & City & of Vero & Beach & 7.70 & 140 & 10 & 2 \\
\hline
\end{tabular}


We1ls in the surficial aquifer system used for data analysis--Continued

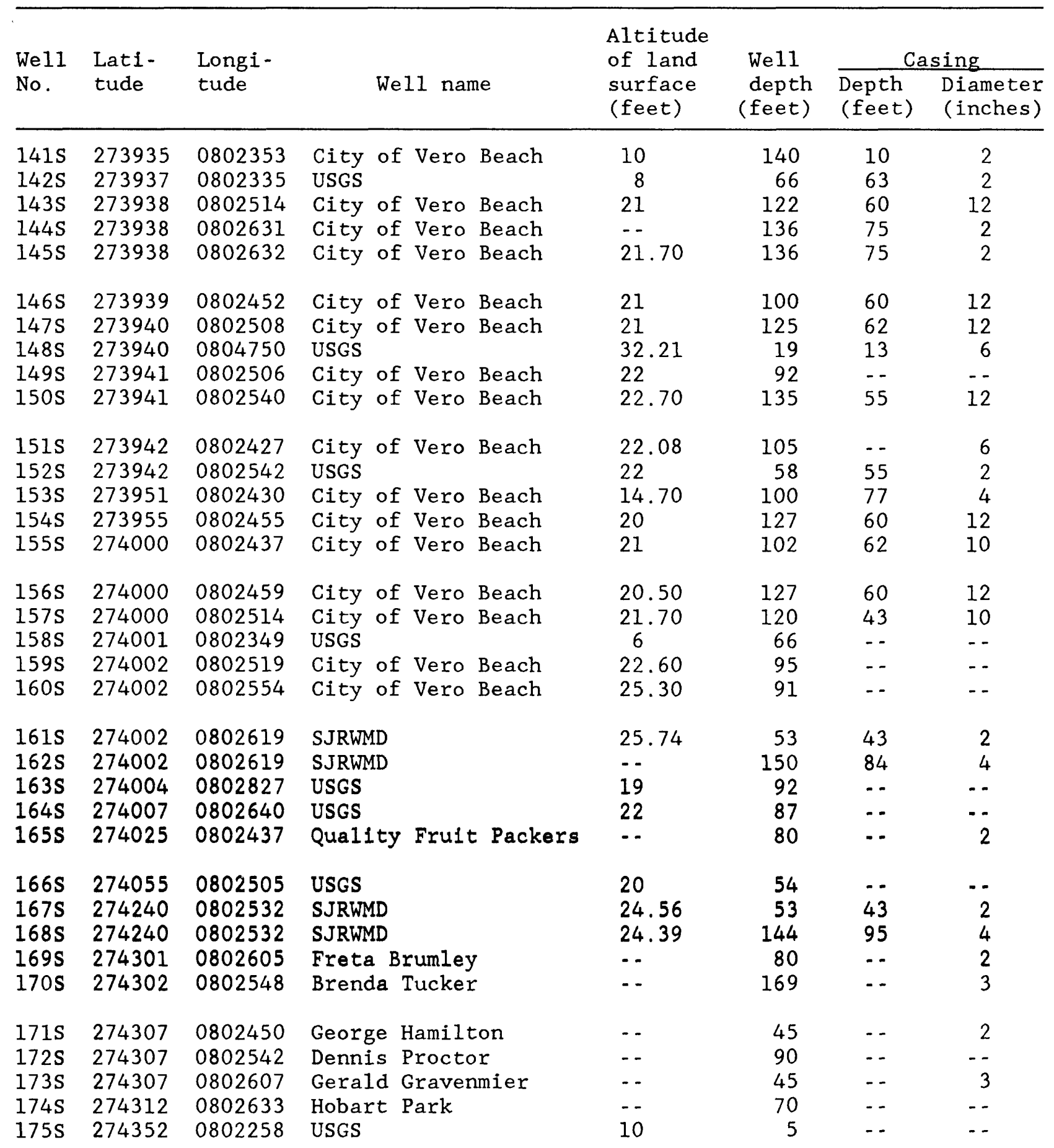


Wells in the surficial aquifer system used for data analysis--Continued

\begin{tabular}{|c|c|c|c|c|c|c|c|}
\hline \multirow{2}{*}{$\begin{array}{l}\text { We11 } \\
\text { No. }\end{array}$} & \multirow{2}{*}{$\begin{array}{l}\text { Lati- } \\
\text { tude }\end{array}$} & \multirow{2}{*}{$\begin{array}{l}\text { Longi - } \\
\text { tude }\end{array}$} & \multirow[b]{2}{*}{ Wel1 name } & \multirow{2}{*}{$\begin{array}{l}\text { Altitude } \\
\text { of land } \\
\text { surface } \\
\text { (feet) }\end{array}$} & \multirow{2}{*}{$\begin{array}{c}\text { Wel1 } \\
\text { depth } \\
\text { (feet) }\end{array}$} & \multicolumn{2}{|c|}{ Casing } \\
\hline & & & & & & $\begin{array}{l}\text { Depth } \\
\text { (feet) }\end{array}$ & $\begin{array}{l}\text { Diameter } \\
\text { (inches) }\end{array}$ \\
\hline $176 \mathrm{~S}$ & 274400 & 0802633 & USGS & 20 & 68 & - & -- \\
\hline $177 \mathrm{~S}$ & 274414 & 0802650 & SJRWMD & 23.61 & 41 & 31 & 2 \\
\hline $178 \mathrm{~S}$ & 274414 & 0802650 & SJRWMD & 24.49 & 137 & 88 & 4 \\
\hline $179 S$ & 274422 & 0803828 & USGS & 23 & 67 & -- & -- \\
\hline $180 \mathrm{~S}$ & 274448 & 0802618 & Graves Bros. Co. & 20 & 888 & - & -- \\
\hline $181 \mathrm{~S}$ & 274448 & 0803146 & Stanley Frontzek & -- & 66 & -- & 2 \\
\hline $182 \mathrm{~S}$ & 274451 & 0802639 & Lost Tree Village & 27.53 & 85 & -- & 2 \\
\hline $183 \mathrm{~S}$ & 274453 & 0802638 & Lost Tree Village & 37 & 90 & 50 & 18 \\
\hline $184 \mathrm{~S}$ & 274453 & 0802752 & N.B. Ryall & -- & 60 & -- & 1.25 \\
\hline $185 \mathrm{~S}$ & 274454 & 0802636 & David Elde11 & - & 60 & -- & 2 \\
\hline $186 \mathrm{~S}$ & 274454 & 0802643 & Minnie Collins & -- & 60 & -- & 2 \\
\hline 187S & 274454 & 0802711 & Florance Johnson & - & 60 & -- & 2 \\
\hline $188 \mathrm{~S}$ & 274454 & 0802756 & Annabelle E. Smith & -- & -- & -- & 4 \\
\hline $189 \mathrm{~S}$ & 274454 & 0802822 & Mrs. Minnie Jones & -- & - & -- & -- \\
\hline $190 S$ & 274454 & 0802957 & Burre11 Lynn & -- & 95 & 80 & 1.25 \\
\hline 191S & 274455 & 0802639 & Queen Johnson & -- & 60 & -- & 2 \\
\hline $192 \mathrm{~S}$ & 274455 & 0802640 & Lost Tree Village & 33 & 85 & 45 & 4 \\
\hline $193 S$ & 274455 & 0802646 & Lost Tree Village & 26.40 & 85 & $-\cdot$ & 2 \\
\hline $194 S$ & 274456 & 0802711 & Rosebud Jones & - & -- & -- & 2 \\
\hline $195 S$ & 274457 & 0802637 & Lost Tree Village & 46.83 & 85 & $\cdots$ & 2 \\
\hline $196 \mathrm{~S}$ & 274457 & 0802751 & Philip Newton & $\cdots$ & 90 & $\cdots$ & 2 \\
\hline $197 \mathrm{~S}$ & 274457 & 0802752 & H. Wilson & -- & 90 & $\cdots$ & 1.5 \\
\hline $198 \mathrm{~S}$ & 274458 & 0802630 & Lost Tree Village & 21.01 & 85 & -- & 2 \\
\hline 199S & 274458 & 0802640 & Lost Tree Village & 34 & 104 & 50 & 18 \\
\hline $200 \mathrm{~S}$ & 274458 & 0802647 & Thomas Ealy & -- & 62 & -- & 2 \\
\hline 2015 & 274459 & 0802606 & R.W. Aughtman & -- & - & -- & 1.5 \\
\hline $202 S$ & 274502 & 0802627 & Lost Tree Village & 20.03 & 85 & - & 2 \\
\hline $203 S$ & 274503 & 0802631 & George Sessions & -- & 87 & -- & 2 \\
\hline $204 \mathrm{~S}$ & 274505 & 0802603 & Harry N. Mills & -- & 24 & 24 & 1.25 \\
\hline $205 S$ & 274506 & 0802601 & John Resanka & -- & 40 & -- & 1.5 \\
\hline $206 S$ & 274506 & 0802603 & Steve Dyalk & -- & 42 & -- & 1.5 \\
\hline $207 S$ & 274506 & 0802603 & Harry N. Mills & -- & 75 & -- & 1.5 \\
\hline $208 \mathrm{~S}$ & 274507 & 0803123 & William R. Gammill & - - & 80 & - & 2 \\
\hline $209 S$ & 274507 & 0803202 & Joel McDaniel & - & 77 & -- & 2 \\
\hline $210 \mathrm{~S}$ & 274508 & 0802644 & Lost Tree Vil'age & 34.86 & 85 & - - & 2 \\
\hline
\end{tabular}


Wells in the surficial aquifer system used for data analysis--Continued

\begin{tabular}{|c|c|c|c|c|c|c|c|}
\hline \multirow{2}{*}{$\begin{array}{l}\text { Well } \\
\text { No. }\end{array}$} & \multirow{2}{*}{$\begin{array}{l}\text { Lati- } \\
\text { tude }\end{array}$} & \multirow{2}{*}{$\begin{array}{l}\text { Longi- } \\
\text { tude }\end{array}$} & \multirow[b]{2}{*}{ Well name } & \multirow{2}{*}{$\begin{array}{l}\text { Altitude } \\
\text { of land } \\
\text { surface } \\
\text { (feet) }\end{array}$} & \multirow{2}{*}{$\begin{array}{l}\text { Well } \\
\text { depth } \\
\text { (feet) }\end{array}$} & \multicolumn{2}{|c|}{ Casing } \\
\hline & & & & & & $\begin{array}{l}\text { Depth } \\
(\text { feet })\end{array}$ & $\begin{array}{l}\text { Diameter } \\
\text { (inches) }\end{array}$ \\
\hline $211 S$ & 274508 & 0803144 & Francis Betz & - & 45 & - & 2 \\
\hline $212 \mathrm{~S}$ & 274509 & 0803048 & Edward Brown & -- & 65 & - & 2 \\
\hline $213 S$ & 274511 & 0803109 & Sharon Moon & -- & 80 & -- & 2 \\
\hline $214 S$ & 274511 & 0803211 & David Finch & -- & -- & - & 2 \\
\hline $215 S$ & 274515 & 0802537 & USGS & 2 & 53 & -- & -- \\
\hline $216 \mathrm{~S}$ & 274517 & 0802618 & SJRWMD & 11.95 & 49 & 39 & 2 \\
\hline $217 S$ & 274517 & 0802618 & SJRWMD & 13.89 & 133 & 85 & 4 \\
\hline $218 \mathrm{~S}$ & 274518 & 0802618 & Tropical Travel Tr. Pk. & 11.80 & 72 & 67 & 2 \\
\hline $219 S$ & 274525 & 0802559 & Olga C. Williams & - & 135 & - & 2 \\
\hline $220 S$ & 274533 & 0802616 & Lowe & - & 70 & -- & 2 \\
\hline $221 S$ & 274535 & 0803154 & USGS & 21 & 67 & - & -- \\
\hline $222 \mathrm{~S}$ & 274538 & 0802833 & Undetermined & - - & 75 & - - & - \\
\hline $223 S$ & 274142 & 0802607 & Joe Tomberg & -- & 70 & -- & 2 \\
\hline $224 S$ & 274542 & 0802841 & Undetermined & -- & 72 & -- & -- \\
\hline $225 S$ & 274547 & 0802352 & John Escobedo & -- & 600 & - & 2 \\
\hline $226 S$ & 274548 & 0802808 & Sebastian Highlands & 23.34 & 102 & 65 & 18 \\
\hline $227 S$ & 274548 & 0803037 & Undetermined & $\ldots$ & 87 & - & - \\
\hline $228 \mathrm{~S}$ & 274549 & 0802350 & William Carnill & - & -- & - - & 2 \\
\hline $229 S$ & 274549 & 0802355 & William Hickey & - & 15 & - & 2 \\
\hline $230 \mathrm{~S}$ & 274552 & 0803505 & W.L. Austin & -- & 60 & -- & 1.5 \\
\hline $231 S$ & 274552 & 0803511 & Frank McManus & - & -- & - & - \\
\hline $232 S$ & 274554 & 0802808 & Sebastian Highlands & 23.65 & 102 & 65 & 18 \\
\hline $233 S$ & 274557 & 0802359 & Larry Lang & -- & 14 & - - & 2.5 \\
\hline $234 \mathrm{~S}$ & 274601 & 0803258 & Stuckey's Rest. I-95 & -- & -- & - & 4 \\
\hline $235 \mathrm{~S}$ & 274602 & 0802823 & Undetermined & -- & 75 & - & -- \\
\hline $236 \mathrm{~S}$ & 274602 & 0803054 & Harry Givens & - & 65 & - & 2 \\
\hline $237 \mathrm{~S}$ & 274603 & 0802411 & Richard Gillespie & - & 18 & - & 2 \\
\hline $238 \mathrm{~S}$ & 274603 & 0802415 & Peter Gasperini & - & 20 & - - & 2 \\
\hline $239 S$ & 274603 & 0803457 & SJRWMD & 30.75 & 140 & 105 & 4 \\
\hline $240 S$ & 274603 & 0803457 & SJRWMD & -- & 45 & 20 & 2 \\
\hline $241 S$ & 274604 & 0802829 & Undetermined & - & 65 & - & - \\
\hline $242 S$ & 274604 & 0802831 & Undetermined & -- & 40 & -- & -- \\
\hline $243 S$ & 274607 & 0802415 & Gerald Horan & - - & -- & - - & - \\
\hline $244 S$ & 274615 & 0802710 & R. Anderson & -- & 25 & 26 & 1.5 \\
\hline $245 S$ & 274616 & 0802703 & Nolan Askins & -- & 22 & 20 & 1.5 \\
\hline
\end{tabular}


We1ls in the surficial aquifer system used for data analysis--Continued

\begin{tabular}{|c|c|c|c|c|c|c|c|}
\hline \multirow{2}{*}{$\begin{array}{l}\text { Wel1 } \\
\text { No. }\end{array}$} & \multirow{2}{*}{$\begin{array}{l}\text { Lati- } \\
\text { tude }\end{array}$} & \multirow{2}{*}{$\begin{array}{l}\text { Longi- } \\
\text { tude }\end{array}$} & \multirow[b]{2}{*}{ Well name } & \multirow{2}{*}{$\begin{array}{l}\text { Altitude } \\
\text { of land } \\
\text { surface } \\
\text { (feet) }\end{array}$} & \multirow{2}{*}{$\begin{array}{l}\text { Well } \\
\text { depth } \\
\text { (feet) }\end{array}$} & \multicolumn{2}{|c|}{ Casing } \\
\hline & & & & & & $\begin{array}{l}\text { Depth } \\
\text { (feet) }\end{array}$ & $\begin{array}{l}\text { Diameter } \\
\text { (inches) }\end{array}$ \\
\hline $246 S$ & 274617 & 0802707 & Johns Piliponis & - & 21 & 17 & 1.5 \\
\hline $247 \mathrm{~S}$ & 274618 & 0802710 & John C. Villarose & - & 44 & 42 & 1.5 \\
\hline $248 S$ & 274619 & 0802641 & R.C. Wilborn & - & 75 & -. & 1.2 \\
\hline $249 S$ & 274636 & 0803001 & Noel Donais & $\ldots$ & 115 & $\ldots$ & 1.5 \\
\hline $250 \mathrm{~S}$ & 274650 & 0802951 & P.E. Lemmon & - & 68 & $\cdots$ & 2 \\
\hline $251 S$ & 274650 & 0802951 & P.E. Lemmon & - & 128 & 105 & 2 \\
\hline $252 \mathrm{~S}$ & 274650 & 0804402 & Undetermined & - & $\ldots$ & - & - \\
\hline $253 \mathrm{~S}$ & 274658 & 0802933 & H.J. Munson & - & 60 & -. & 2 \\
\hline $254 S$ & 274706 & 0802718 & Cooley & - & 50 & - - & 1.25 \\
\hline $255 \mathrm{~S}$ & 274706 & 0802925 & R. Hammond & - & - & $\cdots$ & 2 \\
\hline $256 \mathrm{~S}$ & 274708 & 0802704 & Sam Baugh & $\cdots$ & 115 & - & 1.2 \\
\hline $257 \mathrm{~S}$ & 274709 & 0802708 & J.C. Kopeck & - & 64 & -. & 1.2 \\
\hline $258 \mathrm{~S}$ & 274709 & 0802708 & J.C. Kopeck & $\cdots$ & 400 & - & 2.5 \\
\hline $259 \mathrm{~S}$ & 274709 & 0802711 & J.C. Kopeck & - & 64 & -. & 1.2 \\
\hline $260 \mathrm{~S}$ & 274709 & 0802740 & Max Bressler & $\cdots$ & 70 & $\cdots$ & 2 \\
\hline $261 S$ & 274709 & 0802743 & Arthur Pederquist & $\cdots$ & 120 & - & 2 \\
\hline $262 S$ & 274710 & 0802936 & Ray Nudo & $\ldots$ & 110 & - & 1.25 \\
\hline $263 S$ & 274711 & 0802658 & A. Stuprich & - & 78 & - & 1.5 \\
\hline $264 S$ & 274711 & 0802713 & Harrel Riddle & - & 45 & $\ldots$ & 2 \\
\hline $265 S$ & 274711 & 0802737 & John Thompson & -- & 72 & 50 & 2 \\
\hline $266 S$ & 274711 & 0802747 & Henry Cwik & - & 65 & -. & 2 \\
\hline $267 S$ & 274712 & 0802502 & D'Albora & 9 & 40 & - & 1.5 \\
\hline $268 S$ & 274713 & 0802701 & William Dalrymple & - & 80 & - - & 1.5 \\
\hline $269 S$ & 274714 & 0802739 & James Forward & - & 80 & - & 2 \\
\hline $270 s$ & 274716 & 0802705 & Bill Schardt & $\cdots$ & 90 & - & 1.5 \\
\hline $271 s$ & 274716 & 0802725 & B. Parker & - & - & - & 2 \\
\hline $272 S$ & 274716 & 0802743 & Norris Cox & - & 85 & -. & 2 \\
\hline $273 S$ & 274717 & 0802739 & W.H. Phelan & - & 90 & - - & 2 \\
\hline $274 S$ & 274717 & 0802740 & Arthur Hughes & - & 85 & - . & 2 \\
\hline $275 S$ & 274717 & 0802832 & Sue Guynel & $\cdots$ & 90 & - & 2 \\
\hline $276 S$ & 274719 & 0802704 & G. Roarty & $\cdots$ & 90 & - & 1.5 \\
\hline $277 S$ & 274725 & 0802918 & Tracy Faulkner & -- & 135 & -- & 2 \\
\hline $278 S$ & 274731 & 0802955 & Carl Mullen & - & 80 & $\cdots$ & 1.25 \\
\hline $279 S$ & 274733 & 0802913 & M. Dunn & - & 110 & -- & 2 \\
\hline $280 S$ & 274735 & 0802832 & L.R. White & - & 74 & - & 1.25 \\
\hline
\end{tabular}


Wells in the surficial aquifer system used for data analysis--Continued

\begin{tabular}{|c|c|c|c|c|c|c|c|}
\hline \multirow{2}{*}{$\begin{array}{l}\text { Well } \\
\text { No. }\end{array}$} & \multirow{2}{*}{$\begin{array}{l}\text { Lati- } \\
\text { tude }\end{array}$} & \multirow{2}{*}{$\begin{array}{l}\text { Longi- } \\
\text { tude }\end{array}$} & \multirow[b]{2}{*}{ Well name } & \multirow{2}{*}{$\begin{array}{l}\text { Altitude } \\
\text { of land } \\
\text { surface } \\
\text { (feet) }\end{array}$} & \multirow{2}{*}{$\begin{array}{l}\text { Well } \\
\text { depth } \\
\text { (feet) }\end{array}$} & \multicolumn{2}{|c|}{ Casing } \\
\hline & & & & & & $\begin{array}{l}\text { Depth } \\
\text { (feet) }\end{array}$ & $\begin{array}{l}\text { Diameter } \\
\text { (inches) }\end{array}$ \\
\hline $281 S$ & 274735 & 0802833 & Pearl White & - & 74 & - & 1.25 \\
\hline $282 \mathrm{~S}$ & 274735 & 0802835 & Fredrick Trexler & - - & - - & -- & 1.25 \\
\hline $283 \mathrm{~S}$ & 274736 & 0802848 & John Walker & - - & - - & - - & 1.25 \\
\hline 2845 & 274736 & 0802853 & Paul Crichton & - - & - - & - - & - - \\
\hline $285 S$ & 274747 & 0804434 & USGS & 16 & 35 & - & -- \\
\hline $286 S$ & 274750 & 0802733 & John Timinsky & - & 82 & - & 2 \\
\hline $287 \mathrm{~S}$ & 274758 & 0802736 & Kroegel & - & 520 & - & 4 \\
\hline $288 \mathrm{~S}$ & 274759 & 0802830 & Victor Pelletier & - & - & - & 1.25 \\
\hline $289 \mathrm{~S}$ & 274809 & 0803007 & Thomas J. Pepi & - - & 90 & - & 1 \\
\hline $290 \mathrm{~S}$ & 274823 & 0802747 & Helen Tennyson & -- & 53 & -- & 1.5 \\
\hline $291 S$ & 274823 & 0802747 & Helen Tenyson & - & 53 & - & 1.5 \\
\hline $292 S$ & 274827 & 0802811 & Oscar R. Pedigo & - - & 65 & - & 2 \\
\hline $293 S$ & 274830 & 0802812 & Golem & -- & 90 & 84 & 2 \\
\hline $294 S$ & 274835 & 0804435 & USGS & 12 & 32 & -- & -- \\
\hline $295 S$ & 274840 & 0802811 & Ethal Kinsell & -- & -- & -- & 2 \\
\hline $296 S$ & 274841 & 0803018 & J. Clinton Scott & - & 80 & - & 1.25 \\
\hline $297 S$ & 274843 & 0802814 & Berti Conner & - & 65 & - & 2 \\
\hline $298 \mathrm{~S}$ & 274843 & 0802818 & Carl Lazzeri & - - & - - & - - & -- \\
\hline $299 S$ & 274844 & 0802814 & Sylvia Flood & -- & - - & -- & 4 \\
\hline $300 \mathrm{~S}$ & 274906 & 0802810 & Mrs. Helen Boone & -- & 100 & 97 & 2 \\
\hline 3015 & 274908 & 0803019 & Lester Vander Meer & - & 115 & 100 & 1.25 \\
\hline $302 S$ & 274917 & 0803021 & Charles W. Calkins & - & 115 & 100 & 1.25 \\
\hline $303 S$ & 274918 & 0802816 & Amos J. Simons & -- & -- & - & 2 \\
\hline $304 \mathrm{~S}$ & 274918 & 0803018 & Ray Pospisil & -- & 85 & - & 2 \\
\hline $305 S$ & 274922 & 0803018 & Robert Tanksley & -- & 87 & -- & 2 \\
\hline $306 \mathrm{~S}$ & 274925 & 0802825 & William Wihstutz & - - & 40 & - & 2 \\
\hline $307 \mathrm{~S}$ & 274925 & 0802825 & William Wihstutz & - - & 40 & - - & 2 \\
\hline $308 \mathrm{~s}$ & 274927 & 0802824 & R.G. Bergbom & -- & -- & - & 2 \\
\hline $309 \mathrm{~s}$ & 274932 & 0802828 & Swan & -- & -- & -- & 2 \\
\hline $310 \mathrm{~S}$ & 274937 & 0803006 & Henry Mesec & -- & 126 & - - & 1.25 \\
\hline $311 \mathrm{~S}$ & 274942 & 0802835 & Blizman & -- & 67 & 62 & 2 \\
\hline $312 \mathrm{~S}$ & 274946 & 0802842 & John Crumrine & - - & 90 & -- & 2 \\
\hline $313 \mathrm{~S}$ & 274946 & 0802843 & Charles Rhodes & - - & 400 & - - & 1.5 \\
\hline $314 \mathrm{~S}$ & 274946 & 0802843 & Charles Rhodes & -- & 90 & -- & 2 \\
\hline $315 \mathrm{~S}$ & 274947 & 0802844 & David Burns & - - & 85 & - - & 2 \\
\hline
\end{tabular}


Wells in the surficial aquifer system used for data analysis--Continued

\begin{tabular}{|c|c|c|c|c|c|c|c|}
\hline \multirow{2}{*}{$\begin{array}{l}\text { We11 } \\
\text { No. }\end{array}$} & \multirow{2}{*}{$\begin{array}{l}\text { Lati- } \\
\text { tude }\end{array}$} & \multirow{2}{*}{$\begin{array}{l}\text { Longi- } \\
\text { tude }\end{array}$} & \multirow[b]{2}{*}{ We11 name } & \multirow{2}{*}{$\begin{array}{l}\text { Altitude } \\
\text { of land } \\
\text { surface } \\
\text { (feet) }\end{array}$} & \multirow{2}{*}{$\begin{array}{l}\text { Well } \\
\text { depth } \\
\text { (feet) }\end{array}$} & \multicolumn{2}{|c|}{ Casing } \\
\hline & & & & & & $\begin{array}{l}\text { Depth } \\
(\text { feet })\end{array}$ & $\begin{array}{l}\text { Diameter } \\
\text { (inches) }\end{array}$ \\
\hline $316 S$ & 274948 & 0802916 & SJRWMD & 20.60 & 134 & 105 & 4 \\
\hline $317 \mathrm{~S}$ & 274948 & 0802916 & SJRWMD & 20.68 & 35 & 25 & 2 \\
\hline $318 \mathrm{~S}$ & 274949 & 0802846 & Tim Brussel & -- & 120 & - & 2 \\
\hline $319 \mathrm{~S}$ & 274951 & 0802843 & Irvin Foss & -- & 86 & -- & 2 \\
\hline $320 \mathrm{~s}$ & 274951 & 0802950 & Christena Garry & -- & 65 & -- & 2 \\
\hline $321 \mathrm{~s}$ & 274952 & 0802845 & John Radzinsky & - & 85 & - - & 2 \\
\hline $322 \mathrm{~s}$ & 274953 & 0802953 & A.G. Fletcher & - - & 87 & -- & 1.25 \\
\hline $323 \mathrm{~S}$ & 274954 & 0802843 & Bruce Robert & - & 85 & - & -- \\
\hline $324 \mathrm{~S}$ & 274955 & 0802848 & Ernest Sherwin & - & 94 & - & 2 \\
\hline $325 \mathrm{~S}$ & 274955 & 0802848 & Ernest Sherwin & - & 74 & - & 2 \\
\hline $326 s$ & 274958 & 0802845 & Ruth R. Miller & - & - & - & - \\
\hline $327 \mathrm{~S}$ & 274958 & 0802850 & Mary Bolton & - & 127 & - - & - \\
\hline $328 \mathrm{~s}$ & 274959 & 0802848 & Nino Bertini & -. & 125 & - - & 2 \\
\hline $329 \mathrm{~S}$ & 275002 & 0802935 & Daniel Baker & - - & 80 & - - & 3 \\
\hline $330 \mathrm{~s}$ & 275003 & 0802936 & C.W. King & -- & 82 & -- & 2 \\
\hline $331 S$ & 275010 & 0802858 & Joseph Lutz & -- & 123 & - & 2 \\
\hline $332 \mathrm{~s}$ & 275011 & 0802856 & Thor Tobiason & -- & 85 & - & -- \\
\hline 3335 & 275026 & 0802911 & Vergie Herbert & -- & 80 & - & 2 \\
\hline $334 \mathrm{~S}$ & 275031 & 0802901 & W.C. Tebay & - & 60 & -- & 2 \\
\hline $335 \mathrm{~s}$ & 275052 & 0802911 & Phillip Garcia & -- & 65 & - & 2 \\
\hline $336 \mathrm{~S}$ & 275052 & 0802928 & R.L. Brown & - - & 60 & - & 2 \\
\hline $337 \mathrm{~S}$ & 275056 & 0802916 & Allen Anderson & -- & -- & -- & 1.2 \\
\hline $338 \mathrm{~S}$ & 275059 & 0802926 & S.D. Mason & -- & - & -- & 2 \\
\hline
\end{tabular}




\section{SUPPLEMENTARY DATA II}

Wells in the Floridan aquifer system used for data analys is

[Altitude refers to distance above sea level]

\begin{tabular}{|c|c|c|c|c|}
\hline $\begin{array}{l}\text { Well } \\
\text { No. }\end{array}$ & $\begin{array}{c}\text { Site } \\
\text { identification } \\
\text { No. }\end{array}$ & We11 name & $\begin{array}{l}\text { Altitude } \\
\text { of land } \\
\text { surface } \\
\text { (feet) }\end{array}$ & $\begin{array}{c}\text { Depth } \\
\text { of } \\
\text { well } \\
\text { (feet) }\end{array}$ \\
\hline $\begin{array}{l}1 \mathrm{~F} \\
2 \mathrm{~F} \\
3 \mathrm{~F} \\
4 \mathrm{~F} \\
5 \mathrm{~F}\end{array}$ & $\begin{array}{l}273212080351101 \\
273238080421401 \\
273304080255101 \\
273323080214201 \\
273331080412701\end{array}$ & $\begin{array}{l}\text { SLF-Green Ranch } \\
\text { OKF-2 Evans Groves } \\
\text { StL } 44 \text { McDonald } \\
\text { StL } 48 \text { Dolenick } \\
\text { Evans Groves } 158 \mathrm{~W}\end{array}$ & $\begin{array}{l}20 \\
28.07 \\
20 \\
2 \\
27\end{array}$ & $\begin{array}{l}946 \\
686 \\
691 \\
714 \\
960\end{array}$ \\
\hline $\begin{array}{r}6 \mathrm{~F} \\
7 \mathrm{~F} \\
8 \mathrm{~F} \\
9 \mathrm{~F} \\
10 \mathrm{~F}\end{array}$ & $\begin{array}{l}273332080245001 \\
273335080280901 \\
273336080403001 \\
273342080403001 \\
273355080355601\end{array}$ & $\begin{array}{l}\text { Paramont Aquarium } 27 \text { th Ave. } \\
\text { Edwin Prange } 66 \text { th Ave. } \\
\text { Evans Groves 15AE } \\
\text { Evans Goves 14AE } \\
\text { Brady Groves West of Oslo }\end{array}$ & $\begin{array}{l}22 \\
23 \\
27 \\
27 \\
24\end{array}$ & $\begin{array}{r}1,000 \\
940 \\
900 \\
900 \\
--\end{array}$ \\
\hline $\begin{array}{l}11 \mathrm{~F} \\
12 \mathrm{~F} \\
13 \mathrm{~F} \\
14 \mathrm{~F} \\
15 \mathrm{~F}\end{array}$ & $\begin{array}{l}273357080220201 \\
273357080274901 \\
273401080384101 \\
273402080332001 \\
273402080403001\end{array}$ & $\begin{array}{l}\text { Midway MHP South of Oslo } \\
\text { Vernon Fromarg } 66 \text { th Ave. } \\
\text { Evans Groves 11DE } \\
\text { Morrison Groves } 3 \text { JIMROD } 7 \\
\text { Evans Groves 12AE }\end{array}$ & $\begin{array}{l}5.36 \\
23 \\
23 \\
25 \\
27\end{array}$ & $\begin{array}{r}-- \\
900 \\
\overline{--} \\
940\end{array}$ \\
\hline $\begin{array}{l}16 \mathrm{~F} \\
17 \mathrm{~F} \\
18 \mathrm{~F} \\
19 \mathrm{~F} \\
20 \mathrm{~F}\end{array}$ & $\begin{array}{l}273405080222601 \\
273409080265201 \\
273416080403001 \\
273417080332201 \\
273423080332201\end{array}$ & $\begin{array}{l}\text { Ruth Hallstrum Old Dixie Road } \\
\text { IR } 252 \text { Kings Highway } \\
\text { Evans Groves 10AE } \\
\text { Morrison Goves } 2 \text { JIMROD } 2 \\
\text { Morrison Groves }\end{array}$ & $\begin{array}{l}20 \\
20 \\
27 \\
24 \\
24\end{array}$ & $\begin{array}{r}660 \\
900 \\
1,010 \\
--\end{array}$ \\
\hline $\begin{array}{l}21 F \\
22 F \\
23 F \\
24 F \\
25 F\end{array}$ & $\begin{array}{l}273430080195301 \\
273430080403001 \\
273435080255101 \\
273445080401201 \\
273446080215201\end{array}$ & $\begin{array}{l}\text { Seminole Shores } \\
\text { Evans Groves } 8 \mathrm{AE} \\
\text { USDA South Well } 43 \mathrm{rd} \text { Ave. } \\
\text { Evans Groves 6AE } \\
\text { River Shores South of Oslo }\end{array}$ & $\begin{array}{l}2.01 \\
27 \\
24.60 \\
27 \\
5\end{array}$ & $\begin{array}{r}943 \\
960 \\
-- \\
900 \\
720\end{array}$ \\
\hline $\begin{array}{l}26 \mathrm{~F} \\
27 \mathrm{~F} \\
28 \mathrm{~F} \\
29 \mathrm{~F} \\
30 \mathrm{~F}\end{array}$ & $\begin{array}{l}273459080401201 \\
273501080301501 \\
273501080302101 \\
273510080225301 \\
273510080271901\end{array}$ & $\begin{array}{l}\text { Evans Groves } 4 \mathrm{AE} \\
\text { Dr. Moore Alternate Oslo Road } \\
\text { Dr. Moore Oslo Road } \\
\text { Phillip Helseth Oslo Road } \\
\text { Albert Helseth Oslo Road }\end{array}$ & $\begin{array}{l}27 \\
24 \\
24 \\
19.95 \\
19\end{array}$ & $\begin{array}{r}900 \\
-- \\
880 \\
450 \\
--\end{array}$ \\
\hline $\begin{array}{l}31 F \\
32 F \\
33 F \\
34 F \\
35 F\end{array}$ & $\begin{array}{l}273510080285501 \\
273510080285502 \\
273513080265201 \\
273513080401201 \\
273522080235801\end{array}$ & $\begin{array}{l}\text { Ocean Spray injection monitor } \\
\text { Ocean Spray injection well } \\
\text { IR } 254 \text { SR 505A \& Oslo Road } \\
\text { Evans Groves 2AE } \\
\text { Oslo Nursery Oslo Road }\end{array}$ & $\begin{array}{l}25 \\
25 \\
21 \\
27 \\
22\end{array}$ & $\begin{array}{r}1,960 \\
3,000 \\
760 \\
920 \\
800\end{array}$ \\
\hline
\end{tabular}


We11s in the Floridan aquifer system used for data analysis--Continued

\begin{tabular}{|c|c|c|c|c|}
\hline $\begin{array}{l}\text { Wel1 } \\
\text { No. }\end{array}$ & $\begin{array}{c}\text { Site } \\
\text { identification } \\
\text { No. }\end{array}$ & We11 name & $\begin{array}{l}\text { Altitude } \\
\text { of land } \\
\text { surface } \\
\text { (feet) }\end{array}$ & $\begin{array}{l}\text { Depth } \\
\text { of } \\
\text { we11 } \\
\text { (feet) }\end{array}$ \\
\hline $\begin{array}{l}36 \mathrm{~F} \\
37 \mathrm{~F} \\
38 \mathrm{~F} \\
39 \mathrm{~F} \\
40 \mathrm{~F}\end{array}$ & $\begin{array}{l}273524080262401 \\
273526080240701 \\
273526080261001 \\
273527080263001 \\
273536080240101\end{array}$ & $\begin{array}{l}\text { Albert Helseth Oslo Road } \\
\text { County RO well No. } 2 \\
\text { Albert Helseth Oslo Road } \\
\text { Phillip Helseth Oslo Road } \\
\text { County RO well No. } 1\end{array}$ & $\begin{array}{l}19 \\
22 \\
19 \\
19 \\
22.29\end{array}$ & $\begin{array}{r}700 \\
745 \\
-- \\
750 \\
704\end{array}$ \\
\hline $\begin{array}{l}41 F \\
42 F \\
43 F \\
44 F \\
45 F\end{array}$ & $\begin{array}{l}273536080240201 \\
273539080301901 \\
273542080372001 \\
273543080374101 \\
273559080370301\end{array}$ & $\begin{array}{l}\text { County Ro monitor wel1 } \\
\text { Graves Groves Oslo Road } \\
\text { Tech-ohm Groves } \\
\text { Rancho Santa Maria } 122 \text { Ave. } \\
\text { Tech-ohm Groves } 122 \text { Ave. }\end{array}$ & $\begin{array}{l}22 \\
25 \\
25 \\
24 \\
24\end{array}$ & $\begin{array}{r}901 \\
836 \\
-- \\
-- \\
--\end{array}$ \\
\hline $\begin{array}{l}46 \mathrm{~F} \\
47 \mathrm{~F} \\
48 \mathrm{~F} \\
49 \mathrm{~F} \\
50 \mathrm{~F}\end{array}$ & $\begin{array}{l}273607080310301 \\
273615080283501 \\
273616080470501 \\
273629080260401 \\
273630080460601\end{array}$ & $\begin{array}{l}\text { Ball Groves } 90 \text { th Ave. } \\
\text { Jackson Groves Carter Ave. } \\
\text { Latt Maxcy } \\
\text { IR } 256 \text { Lillian Lockwood } \\
\text { Latt Maxcy K-4 }\end{array}$ & $\begin{array}{l}24 \\
21 \\
36 \\
20 \\
31\end{array}$ & $\begin{array}{r}1,100 \\
860 \\
912 \\
700 \\
--\end{array}$ \\
\hline $\begin{array}{l}51 F \\
52 F \\
53 F \\
54 F \\
55 F\end{array}$ & $\begin{array}{l}273632080364501 \\
273633080351001 \\
273633080364301 \\
273639080261501 \\
273649080452701\end{array}$ & $\begin{array}{l}\text { IR } 266 \text { Citrus Road \& } 90 \text { th Ave. } \\
\text { Gracewood Groves Heritage Road } \\
\text { Rio Groves McClelland Road } \\
\text { L. Gollnick Groves } 4 \text { th Street } \\
\text { IR } 202 \text { Latt Maxcy F-7 }\end{array}$ & $\begin{array}{l}24.06 \\
24 \\
25 \\
22 \\
28\end{array}$ & $\begin{array}{r}1,100 \\
\cdots \\
900 \\
730\end{array}$ \\
\hline $\begin{array}{l}56 \mathrm{~F} \\
57 \mathrm{~F} \\
58 \mathrm{~F} \\
59 \mathrm{~F} \\
60 \mathrm{~F}\end{array}$ & $\begin{array}{l}273656080230701 \\
273710080230601 \\
273719080225601 \\
273722080455901 \\
273723080255401\end{array}$ & $\begin{array}{l}\text { Tropic Villas No. } 2 \\
\text { Tropic Villas No. } 1 \\
\text { IR } 24312 \text { th Street } \\
\text { Latt Maxcy K- } 11 \\
\text { IR } 255 \mathrm{Mr} \text {. Young } 43 \text { rd Ave. }\end{array}$ & $\begin{array}{r}8 \\
8 \\
3 \\
27 \\
21\end{array}$ & $\begin{array}{r}703 \\
660 \\
941 \\
-- \\
575\end{array}$ \\
\hline $\begin{array}{l}61 F \\
62 F \\
63 F \\
64 F \\
65 F\end{array}$ & $\begin{array}{l}273726080371501 \\
273726080471701 \\
273740080335701 \\
273741080382701 \\
273756080371401\end{array}$ & $\begin{array}{l}\text { Talmadge Brothers Groves } \\
\text { Latt Maxcy } \\
\text { Lykes Pasco No. } 6 \\
\text { Eder Groves 122nd Ave. } \\
\text { Talmedge Bros. Groves }\end{array}$ & $\begin{array}{l}24 \\
32 \\
26 \\
26 \\
24\end{array}$ & $\begin{array}{r}960 \\
\cdots \\
1,100 \\
570 \\
1,000\end{array}$ \\
\hline $\begin{array}{l}66 \mathrm{~F} \\
67 \mathrm{~F} \\
68 \mathrm{~F} \\
69 \mathrm{~F} \\
70 \mathrm{~F}\end{array}$ & $\begin{array}{l}273758080301501 \\
273801080301701 \\
273802080375701 \\
273805080223901 \\
273807080450201\end{array}$ & $\begin{array}{l}\text { Village Green Southwest } \\
\text { Village Green South } 90 \text { Ave. } \\
\text { Cardinal Groves } 122 \text { Ave. } \\
\text { Vero Beach Power Plant No. } 2 \\
\text { K. Prince St. Johns Marsh }\end{array}$ & $\begin{array}{r}22 \\
23 \\
26 \\
3 \\
24\end{array}$ & $\begin{array}{r}766 \\
704 \\
540 \\
-- \\
750\end{array}$ \\
\hline
\end{tabular}


Wells in the Floridan aquifer system used for data analysis--Continued

\begin{tabular}{|c|c|c|c|c|}
\hline $\begin{array}{l}\text { We11 } \\
\text { No. }\end{array}$ & $\begin{array}{c}\text { Site } \\
\text { identification } \\
\text { No. }\end{array}$ & We11 name & $\begin{array}{l}\text { Altitude } \\
\text { of land } \\
\text { surface } \\
\text { (feet) }\end{array}$ & $\begin{array}{c}\text { Depth } \\
\text { of } \\
\text { we } 11 \\
\text { (feet) }\end{array}$ \\
\hline $\begin{array}{l}71 \mathrm{~F} \\
72 \mathrm{~F} \\
73 \mathrm{~F} \\
74 \mathrm{~F} \\
75 \mathrm{~F}\end{array}$ & $\begin{array}{l}273812080382701 \\
273814080245201 \\
273815080235101 \\
273818080235201 \\
273818080284801\end{array}$ & $\begin{array}{l}\text { Eder Groves } 122 \text { nd Ave. } \\
\text { IR } 24 \text { lst Christ Church } \\
\text { IR } 10 / 241 \text { old VB Power Plant } \\
\text { IR } 200 \text { old VB Power Plant } \\
\text { Williams Groves SR } 60\end{array}$ & $\begin{array}{l}26 \\
20 \\
20 \\
15 \\
22\end{array}$ & $\begin{array}{l}800 \\
671 \\
665 \\
700 \\
725\end{array}$ \\
\hline $\begin{array}{l}76 \mathrm{~F} \\
77 \mathrm{~F} \\
78 \mathrm{~F} \\
79 \mathrm{~F} \\
80 \mathrm{~F}\end{array}$ & $\begin{array}{l}273819080260101 \\
273821080273901 \\
273822080374401 \\
273822080374402 \\
273827080322001\end{array}$ & $\begin{array}{l}\text { IR } 228 \text { F Pollock SR } 60 \\
\text { Chauncey Hatch Jr. SR } 60 \\
\text { Cardina1 Groves Pond Wel1 } \\
\text { Cardinal Groves unused } \\
\text { SR } 60 \text { West of I-95 }\end{array}$ & $\begin{array}{l}23.35 \\
21 \\
24 \\
23.00 \\
23\end{array}$ & $\begin{array}{r}750 \\
746 \\
-- \\
604 \\
--\end{array}$ \\
\hline $\begin{array}{l}81 \mathrm{~F} \\
82 \mathrm{~F} \\
83 \mathrm{~F} \\
84 \mathrm{~F} \\
85 \mathrm{~F}\end{array}$ & $\begin{array}{l}273828080283801 \\
273828080283901 \\
273833080233901 \\
273833080461901 \\
273835080345801\end{array}$ & $\begin{array}{l}\text { Village Green No. } 2 \text { SR } 60 \\
\text { Village Green No. } 1 \text { SR } 60 \\
\text { IR } 23 \text { Episcopal Church } \\
\text { IR } 205 \mathrm{~K} \text { Prince } \\
\text { Kromhout Groves SR } 60\end{array}$ & $\begin{array}{l}23 \\
23 \\
10 \\
28.06 \\
24\end{array}$ & $\begin{array}{r}780 \\
760 \\
690 \\
-- \\
600\end{array}$ \\
\hline $\begin{array}{l}86 \mathrm{~F} \\
87 \mathrm{~F} \\
88 \mathrm{~F} \\
89 \mathrm{~F} \\
90 \mathrm{~F}\end{array}$ & $\begin{array}{l}273839080244101 \\
273840080320701 \\
273846080254701 \\
273852080283601 \\
273854080464401\end{array}$ & $\begin{array}{l}\text { Village Green MHP SR } 60 \\
\text { Lambeth Groves SR } 60 \\
\text { USDA North We11 } 43 \text { rd Ave. } \\
\text { Village Green } 26 \text { th St. aban. } \\
\text { Eatmon Ranch }\end{array}$ & $\begin{array}{l}20 \\
26 \\
22 \\
20 \\
26\end{array}$ & $\begin{array}{r}-- \\
975 \\
-- \\
562 \\
920\end{array}$ \\
\hline $\begin{array}{l}91 \mathrm{~F} \\
92 \mathrm{~F} \\
93 \mathrm{~F} \\
94 \mathrm{~F} \\
95 \mathrm{~F}\end{array}$ & $\begin{array}{l}273859080235101 \\
273900080232301 \\
273905080241101 \\
273912080241401 \\
273927080465701\end{array}$ & $\begin{array}{l}30 \text { th Street Vero Beach } \\
\text { IR } 240 \text { Royal Palm Golf Club } \\
\text { Vero Beach No. } 21 \text { Airport } \\
\text { Vero Beach No } 14 \text { Airport } \\
\text { Eatmon Ranch West }\end{array}$ & $\begin{array}{l}8.51 \\
5 \\
20 \\
15 \\
27\end{array}$ & $\begin{array}{l}-- \\
550 \\
688 \\
688 \\
960\end{array}$ \\
\hline $\begin{array}{r}96 \mathrm{~F} \\
97 \mathrm{~F} \\
98 \mathrm{~F} \\
99 \mathrm{~F} \\
100 \mathrm{~F}\end{array}$ & $\begin{array}{l}273940080472101 \\
273945080281801 \\
273947080230501 \\
273953080274801 \\
273957080291501\end{array}$ & $\begin{array}{l}\text { Leroy Pressley SR } 60 \\
\text { J. Johnson Barber Ave. } \\
\text { Mosquito Control We11 } \\
\text { IR } 208 \text { Frank Bates } \\
\text { Takaho Groves Block } 13 \& 14\end{array}$ & $\begin{array}{r}29 \\
20 \\
5 \\
20 \\
19\end{array}$ & $\begin{array}{r}7 \overline{7} \\
=- \\
700 \\
882\end{array}$ \\
\hline $\begin{array}{l}101 \mathrm{~F} \\
102 \mathrm{~F} \\
103 \mathrm{~F} \\
104 \mathrm{~F} \\
105 \mathrm{~F}\end{array}$ & $\begin{array}{l}274005080244901 \\
274008080255301 \\
274016080481601 \\
274023080291401 \\
274028080384301\end{array}$ & $\begin{array}{l}\text { IR } 230 \text { South Gifford Road } \\
\text { Jackson Groves S. Gifford Road } \\
\text { K.D. Eatmon SR } 60 \\
\text { Takaho Groves B1k } 9 \& 10 \\
\text { Diamond G Farm SR } 512\end{array}$ & $\begin{array}{l}19.34 \\
23.57 \\
36 \\
20 \\
22\end{array}$ & $\begin{array}{r}720 \\
960 \\
-- \\
966 \\
--\end{array}$ \\
\hline
\end{tabular}


Wells in the Floridan aquifer system used for data analysis--Continued

\begin{tabular}{|c|c|c|c|c|}
\hline $\begin{array}{l}\text { Well } \\
\text { No. }\end{array}$ & $\begin{array}{c}\text { Site } \\
\text { identification } \\
\text { No. }\end{array}$ & We11 name & $\begin{array}{l}\text { Altitude } \\
\text { of land } \\
\text { surface } \\
\text { (feet) }\end{array}$ & $\begin{array}{c}\text { Depth } \\
\text { of } \\
\text { we11 } \\
\text { (feet) }\end{array}$ \\
\hline $\begin{array}{l}106 \mathrm{~F} \\
107 \mathrm{~F} \\
108 \mathrm{~F} \\
109 \mathrm{~F} \\
110 \mathrm{~F}\end{array}$ & $\begin{array}{l}274047080513701 \\
274055080281301 \\
274113080475501 \\
274114080474901 \\
274115080291401\end{array}$ & $\begin{array}{l}\text { USGS TH Site near Yeehaw } \\
\text { IR } 210 \text { Walter Pool } \\
\text { IR } 185 \mathrm{~W} \text {. Surrency } \\
\text { L. Pressley Blue Cypress Road } \\
\text { Takaho Groves Blk } 1 \& 2\end{array}$ & $\begin{array}{l}58 \\
19 \\
33 \\
31 \\
20\end{array}$ & $\begin{array}{l}305 \\
650 \\
700 \\
550 \\
886\end{array}$ \\
\hline $\begin{array}{l}111 \mathrm{~F} \\
112 \mathrm{~F} \\
113 \mathrm{~F} \\
114 \mathrm{~F} \\
115 \mathrm{~F}\end{array}$ & $\begin{array}{l}274116080265001 \\
274121080241701 \\
274142080294301 \\
274150080260901 \\
274156080344301\end{array}$ & $\begin{array}{l}\text { IR } 216 \text { SR \#505A } \\
\text { IR } 233 \text { Kennedy Grove } \\
\text { IR } 226 \text { Ranch Road } \\
\text { Kings Highway } \\
\text { Jack Berry Grove Blk } 99\end{array}$ & $\begin{array}{l}21 \\
6.65 \\
21 \\
22 \\
23\end{array}$ & $\begin{array}{r}635 \\
635 \\
-- \\
472 \\
700\end{array}$ \\
\hline $\begin{array}{l}116 \mathrm{~F} \\
117 \mathrm{~F} \\
118 \mathrm{~F} \\
119 \mathrm{~F} \\
120 \mathrm{~F}\end{array}$ & $\begin{array}{l}274157080263801 \\
274203080292901 \\
274206080225501 \\
274210080400301 \\
274216080264301\end{array}$ & $\begin{array}{l}\text { Kings Highway } \\
\text { Gracewood Groves } \\
\text { Johns Island Well } \\
\text { Fellsmere JV Ditch } 33 \\
\text { Kings Highway }\end{array}$ & $\begin{array}{r}22 \\
22 \\
2.90 \\
18 \\
22\end{array}$ & $\begin{array}{r}556 \\
890 \\
2,020 \\
700 \\
579\end{array}$ \\
\hline $\begin{array}{l}121 \mathrm{~F} \\
122 \mathrm{~F} \\
123 \mathrm{~F} \\
124 \mathrm{~F} \\
125 \mathrm{~F}\end{array}$ & $\begin{array}{l}274223080371501 \\
274226080242501 \\
274250080354401 \\
274250080355001 \\
274302080260901\end{array}$ & $\begin{array}{l}\text { Fellsmere JV Ditch } 32 \\
\text { IR } 234 \text { North of Gifford } \\
\text { Jack Berry Groves B1k } 55 \\
\text { Jack Berry Groves B1k } 54 \\
\text { Bruce Chalker }\end{array}$ & $\begin{array}{r}24 \\
4 \\
23 \\
23 \\
18\end{array}$ & $\begin{array}{l}600 \\
500 \\
700 \\
700 \\
405\end{array}$ \\
\hline $\begin{array}{l}126 \mathrm{~F} \\
127 \mathrm{~F} \\
128 \mathrm{~F} \\
129 \mathrm{~F} \\
130 \mathrm{~F}\end{array}$ & $\begin{array}{l}274302080371501 \\
274303080380401 \\
274309080245001 \\
274309080265301 \\
274310080293301\end{array}$ & $\begin{array}{l}\text { Fellsmere JV Ditch } 29 \\
\text { Fellsmere JV Ditch } 8 \\
\text { IR } 235 \text { George Hamilton } \\
\text { CIBA Geigy Co. } \\
\text { IR } 58 \text { Graves Bros. }\end{array}$ & $\begin{array}{r}24 \\
22 \\
5 \\
24.32 \\
20\end{array}$ & $\begin{array}{l}650 \\
760 \\
500 \\
651 \\
400\end{array}$ \\
\hline $\begin{array}{l}131 \mathrm{~F} \\
132 \mathrm{~F} \\
133 \mathrm{~F} \\
134 \mathrm{~F} \\
135 \mathrm{~F}\end{array}$ & $\begin{array}{l}274313080283701 \\
274337080233901 \\
274345080413201 \\
274350080364501 \\
274404080233601\end{array}$ & $\begin{array}{l}\text { H. Prange } \\
\text { IR } 116 \text { Jungle Trail } \\
\text { Fellsmere JV Lat } 26 \\
\text { Jack Berry Groves B1k } 11 \\
\text { IR } 114 \mathrm{R} \text {. Jones Jungle Trail }\end{array}$ & $\begin{array}{r}20 \\
3 \\
20 \\
24 \\
3\end{array}$ & $\begin{array}{l}800 \\
650 \\
460 \\
708 \\
586\end{array}$ \\
\hline $\begin{array}{l}136 \mathrm{~F} \\
137 \mathrm{~F} \\
138 \mathrm{~F} \\
139 \mathrm{~F} \\
140 \mathrm{~F}\end{array}$ & $\begin{array}{l}274436080395801 \\
274445080235901 \\
274447080235301 \\
274448080373201 \\
274449080240001\end{array}$ & $\begin{array}{l}\text { Fellsmere JV Ditch } 22 \\
\text { IR } 104 \text { Deerfield Groves } \\
\text { IR } 108 \text { Deerfield Groves } \\
\text { IR } 203 \text { Dietz We11 } \\
\text { IR } 107 \text { Deerfield Groves }\end{array}$ & $\begin{array}{r}20 \\
3 \\
7 \\
22 \\
3\end{array}$ & $\begin{array}{r}650 \\
1,000 \\
860 \\
590 \\
991\end{array}$ \\
\hline
\end{tabular}


Wells in the Floridan aquifer system used for data analysis--Continued

\begin{tabular}{|c|c|c|c|c|}
\hline $\begin{array}{l}\text { Well } \\
\text { No. }\end{array}$ & $\begin{array}{c}\text { Site } \\
\text { identification } \\
\text { No. }\end{array}$ & Well name & $\begin{array}{l}\text { Altitude } \\
\text { of land } \\
\text { surface } \\
\text { (feet) }\end{array}$ & $\begin{array}{l}\text { Depth } \\
\text { of } \\
\text { well } \\
\text { (feet) }\end{array}$ \\
\hline $141 \mathrm{~F}$ & 274450080232401 & Baytree AlA & 8.30 & 1,050 \\
\hline $142 \mathrm{~F}$ & 274452080275501 & IR 147 A.S. Pfarr & 21 & 620 \\
\hline $143 \mathrm{~F}$ & 274455080263701 & Johns Island Golf Course & 37 & 560 \\
\hline $144 \mathrm{~F}$ & 274459080490501 & Rollins Ranch North of Yeehaw & 31 & 416 \\
\hline $145 \mathrm{~F}$ & 274501080282101 & IR 160 West of Wabasso & 20 & 600 \\
\hline $146 \mathrm{~F}$ & 274502080395801 & Fellsmere JV Ditch 20 & 20 & 650 \\
\hline $147 \mathrm{~F}$ & 274503080413001 & Felismere JV Lat 20 & 20 & 399 \\
\hline $148 \mathrm{~F}$ & 274514080365601 & Harold Platt & 23 & - \\
\hline $149 \mathrm{~F}$ & 274522080304301 & SR 510 South of River Bridge & 20 & 465 \\
\hline $150 \mathrm{~F}$ & 274524080240801 & North Beach Water Co. No. 2 & 3 & 960 \\
\hline $151 \mathrm{~F}$ & 274528080395801 & Fellsmere JV Ditch 18 & 20 & 650 \\
\hline $152 \mathrm{~F}$ & 274528080412901 & Fellsmere JV Lat 18 & 22 & - \\
\hline $153 \mathrm{~F}$ & 274529080423001 & Fellsmere JV Lat $18 \& Q$ Canal & 22 & 400 \\
\hline $154 \mathrm{~F}$ & 274532080241801 & North Beach Water Co. No. 1 & 3 & 1,000 \\
\hline $155 \mathrm{~F}$ & 274534080251101 & Marsh Island & 3 & 390 \\
\hline $156 \mathrm{~F}$ & 274538080281601 & IR 155 Sebastian Highlands & 21.52 & -- \\
\hline $157 \mathrm{~F}$ & 274549080245201 & IR 73 Deerfield Groves & 3 & 800 \\
\hline $158 \mathrm{~F}$ & 274552080242201 & IR 82 Deerfield Groves & 5 & 950 \\
\hline $159 \mathrm{~F}$ & 274553080243801 & IR 69 Deerfield Groves & 3 & 550 \\
\hline $160 \mathrm{~F}$ & 274553080245801 & IR 72 Deerfield Groves & 3 & 800 \\
\hline $161 \mathrm{~F}$ & 274556080412901 & Fellsmere JV Lat 16 & 20 & 405 \\
\hline $162 \mathrm{~F}$ & 274557080343001 & Carol City Aquarium & 28 & 786 \\
\hline $163 \mathrm{~F}$ & 274558080304201 & John Bradley River Bridge & 19 & 540 \\
\hline $164 \mathrm{~F}$ & 274601080313801 & IR 175 SR 510 & 19 & 600 \\
\hline $165 \mathrm{~F}$ & 274603080485201 & Rollins Ranch North of Yeehaw & 28 & - \\
\hline $166 \mathrm{~F}$ & 274606080335401 & Schiner Memorial Well & 31 & -- \\
\hline $167 \mathrm{~F}$ & 274607080264001 & Pelican Pointe & 9 & 357 \\
\hline $168 \mathrm{~F}$ & 274607080493001 & USGS Observation Well IR 189 & 33.66 & 630 \\
\hline $169 \mathrm{~F}$ & 274608080412901 & Fellsmere JV Lat 15 & 20 & 405 \\
\hline $170 \mathrm{~F}$ & 274609080502801 & Rollins Ranch No. 1 & 42 & 605 \\
\hline $171 \mathrm{~F}$ & 274621080300901 & Roseland Acres & 17.66 & - \\
\hline $172 \mathrm{~F}$ & 274623080503201 & Oil Test Rollins Ranch & 60 & 9,480 \\
\hline $173 \mathrm{~F}$ & 274625080242101 & Kohl at Wabasso Beach & 7 & 1,272 \\
\hline $174 \mathrm{~F}$ & 274635080244501 & IR 60 Deerfield Groves & 6 & 550 \\
\hline $175 \mathrm{~F}$ & 274635080363001 & IR 183 Joe Screws & 24 & 640 \\
\hline
\end{tabular}


Wells in the Floridan aquifer system used for data analysis--Continued

\begin{tabular}{|c|c|c|c|c|}
\hline $\begin{array}{l}\text { Well } \\
\text { No. }\end{array}$ & $\begin{array}{c}\text { Site } \\
\text { identification } \\
\text { No. }\end{array}$ & We11 name & $\begin{array}{l}\text { Altitude } \\
\text { of land } \\
\text { surface } \\
\text { (feet) }\end{array}$ & $\begin{array}{l}\text { Depth } \\
\text { of } \\
\text { well } \\
\text { (feet) }\end{array}$ \\
\hline $176 \mathrm{~F}$ & 274636080244001 & IR 59 Deerfield Groves & 6 & 650 \\
\hline $177 \mathrm{~F}$ & 274640080243401 & IR 201 Deerfield Groves & 8 & 883 \\
\hline $178 \mathrm{~F}$ & 274640080243801 & IR 52 Deerfield Groves & 7 & 750 \\
\hline $179 \mathrm{~F}$ & 274641080244701 & IR 51 Deerfield Groves & 20 & 800 \\
\hline $180 \mathrm{~F}$ & 274642080453601 & Rollins Ranch pumphouse & 27 & 600 \\
\hline $181 F$ & 274646080243801 & IR 50 Deerfield Groves & 7 & 750 \\
\hline $182 \mathrm{~F}$ & 274647080313401 & IR 169 C L'Orange & 18 & 525 \\
\hline $183 \mathrm{~F}$ & 274650080413001 & IR 186 Fellsmere JV Lat 12 & 20 & - - \\
\hline $184 \mathrm{~F}$ & 274650080425901 & Fellsmere JV Lat 12 & 20 & 340 \\
\hline $185 \mathrm{~F}$ & 274650080440201 & Fellsmere JV Lat 12 No. 1 & 20 & 380 \\
\hline $186 \mathrm{~F}$ & 274659080244301 & IR 49 B.F. Bailey & 7 & 760 \\
\hline $187 \mathrm{~F}$ & 274700080243901 & IR 46 B.F. Bailey & 8 & 850 \\
\hline $188 \mathrm{~F}$ & 274700080245101 & IR 47 B.F. Bailey & 6 & 700 \\
\hline $189 \mathrm{~F}$ & 274705080460301 & Rollins Ranch Silage Road & 20 & 600 \\
\hline $190 \mathrm{~F}$ & 274705080470201 & Rollins Ranch Silage Road No.1 & 20 & 600 \\
\hline $191 \mathrm{~F}$ & 274706080454901 & Rollins Ranch Silage Road No.2 & 20 & 600 \\
\hline $192 \mathrm{~F}$ & 274712080491101 & Rollins Ranch North of Yeehaw & 28 & -- \\
\hline $193 \mathrm{~F}$ & 274718080440201 & Fellsmere JV Lat 10 & 20 & 360 \\
\hline $194 \mathrm{~F}$ & 274719080274301 & General Development Co. & 25 & 510 \\
\hline $195 \mathrm{~F}$ & 274744080465001 & Blue Cypress Ranch & 23 & -- \\
\hline $196 \mathrm{~F}$ & 274751080480801 & Blue Cypress Ranch nr old shop & 23 & -- \\
\hline $197 \mathrm{~F}$ & 274801080482001 & Blue Cypress Ranch unused & 24 & -- \\
\hline $198 \mathrm{~F}$ & 274814080303301 & Carl L'Orange Sebastian River & 2 & 491 \\
\hline $199 \mathrm{~F}$ & 274815080254101 & IR 33 A.J. Byrd & 3 & 540 \\
\hline $200 F$ & 274837080293501 & Sebastian Country Club & 22 & 840 \\
\hline $201 \mathrm{~F}$ & 274838080275501 & IR 131 P.R. Stevenson & 7 & - \\
\hline $202 \mathrm{~F}$ & 274843080471401 & Blue Cypress Ranch near shop & 23 & - - \\
\hline $203 \mathrm{~F}$ & 274857080493401 & Yates Well near Sebastian & 28 & 233 \\
\hline $204 \mathrm{~F}$ & 274915080362501 & IR $180 \mathrm{~A}$. Beckman & 25 & 425 \\
\hline $205 F$ & 274916080520701 & USGS TH Mace Ranch & 53 & 260 \\
\hline $206 \mathrm{~F}$ & 274921080254201 & Indian River County AIA & 5 & - - \\
\hline $207 F$ & 274927080290601 & $B$ and S Fish Co. & 22 & 700 \\
\hline $208 \mathrm{~F}$ & 274935080282601 & Sembler Well Sebastian & 6 & 475 \\
\hline $209 F$ & 274942080404001 & Fellsmere Joint Venture & 25 & 500 \\
\hline $210 \mathrm{~F}$ & 275018080261201 & McLarty Museum & 4.96 & - - \\
\hline
\end{tabular}


Wells in the Floridan aquifer system used for data analysis--Continued

\begin{tabular}{|c|c|c|c|c|}
\hline $\begin{array}{l}\text { We11 } \\
\text { No. }\end{array}$ & $\begin{array}{c}\text { Site } \\
\text { identification } \\
\text { No. }\end{array}$ & Well name & $\begin{array}{l}\text { Altitude } \\
\text { of land } \\
\text { surface } \\
\text { (feet) }\end{array}$ & $\begin{array}{c}\text { Depth } \\
\text { of } \\
\text { well } \\
\text { (feet) }\end{array}$ \\
\hline $\begin{array}{l}211 F \\
212 F \\
213 F \\
214 F \\
215 F\end{array}$ & $\begin{array}{l}275047080292401 \\
275057080292301 \\
275108080271001 \\
275114080265401 \\
275117080270401\end{array}$ & $\begin{array}{l}\text { Kip Wagner Roseland } \\
\text { Bob's Inn Roseland } \\
\text { State Park Sebastian Inlet } \\
\text { Mosquito Control Well Seb. Inlet } \\
\text { State Park Seb. Inlet unused }\end{array}$ & $\begin{array}{r}25 \\
26 \\
5 \\
3 \\
4.96\end{array}$ & $\begin{array}{r}600 \\
409 \\
480 \\
480\end{array}$ \\
\hline $\begin{array}{l}216 \mathrm{~F} \\
217 \mathrm{~F}\end{array}$ & $\begin{array}{l}275119080482401 \\
275210080272201\end{array}$ & $\begin{array}{l}\text { Gilbert Tucker } \\
\text { DR0624 Seb. Inlet Test Well }\end{array}$ & $\begin{array}{r}21 \\
2\end{array}$ & $\begin{array}{l}594 \\
650\end{array}$ \\
\hline
\end{tabular}

